UNIVERSIDADE DE SÃO PAULO

INSTITUTO DE ARQUITETURA E URBANISMO

\title{
Planejar com a Paisagem: potenciais espaços livres para um Sistema em São Carlos
}

Ana Carolina da Fonseca Pires

Dissertação de Mestrado

São Carlos

2020 

UNIVERSIDADE DE SÃO PAULO

INSTITUTO DE ARQUITETURA E URBANISMO

PROGRAMA DE PÓS-GRADUAÇÃO EM ARQUITETURA E URBANISMO

\title{
Planejar com a Paisagem:
}

\section{potenciais espaços livres para um Sistema em São Carlos}

\author{
Versão Corrigida
}

Dissertação apresentada ao Programa de Pós-Graduação em Arquitetura e Urbanismo do Instituto de Arquitetura e Urbanismo da Universidade de São Paulo para a obtenção do título de Mestre.

\section{Ana Carolina da Fonseca Pires}

Área de concentração: Teoria e História da Arquitetura e Urbanismo Linha de pesquisa: Arquitetura, Cidade e Paisagem no Brasil e na América Latina

Orientadora: Profa. Dra. Luciana Bongiovanni Martins Schenk

\section{São Carlos}

2020 
AUTORIZO A REPRODUCAO TOTAL OU PARCIAL DESTE TRABALHO,

POR QUALQUER MEIO CONVENCIONAL OU ELETRONICO, PARA FINS

DE ESTUDO E PESQUISA, DESDE QUE CITADA A FONTE

Ficha catalográfica elaborada pela Biblioteca do Instituto de Arquitetura e Urbanismo com os dados fornecidos pelo(a) autor(a)

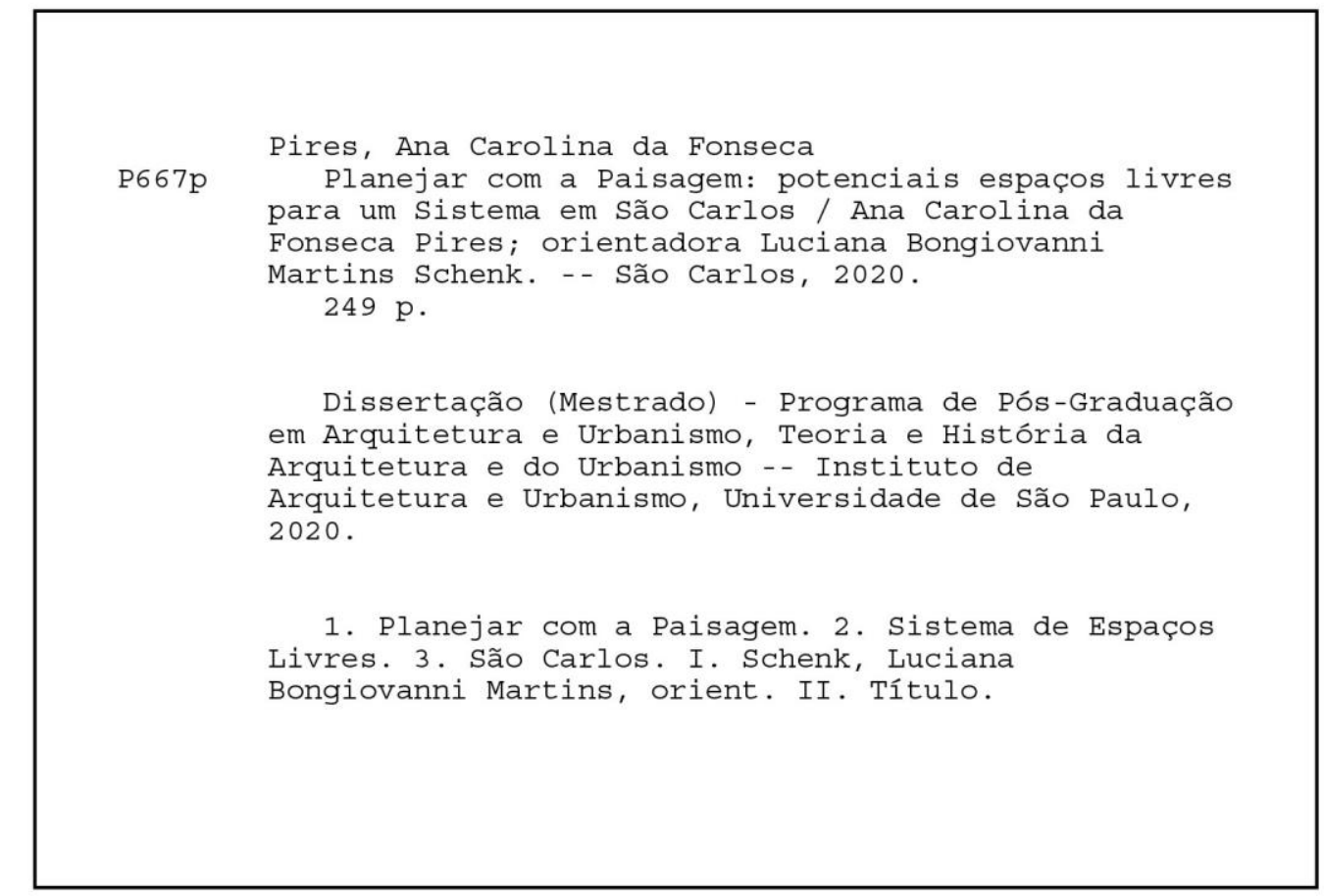

Bibliotecária responsável pela estrutura de catalogação da publicação de acordo com a AACR2:

Brianda de Oliveira Ordonho Sígolo - CRB - 8/8229 


\section{FOLHA DE JULGAMENTO}

Candidato(a): Ana Carolina da Fonseca Pires

Título da dissertação: "Planejar com a Paisagem: potenciais espaços livres para um Sistema em São Carlos"

Data da defesa: 29/05/2020

Orientador: Profa. Dra. Luciana Bongiovanni Martins Schenk

Comissão Julgadora:

Resultado:

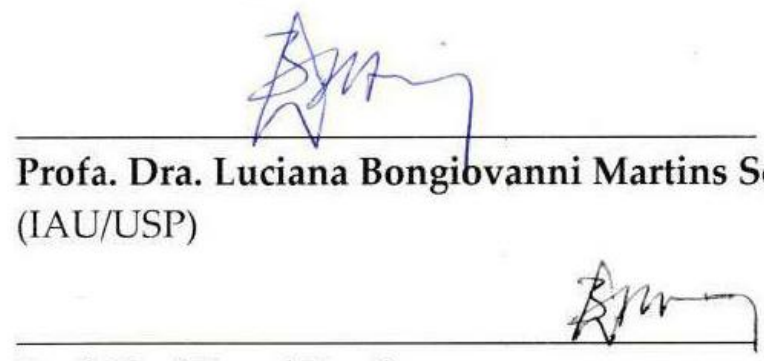

Prof. Dr. Marcel Fantin

APROVARA

(IAU/USP)

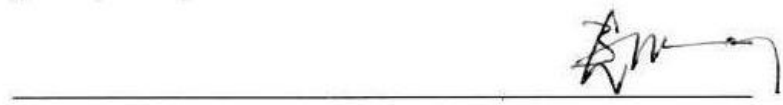

Profa. Dra. Renata Bovo Peres

Não votante

(UFSCar)

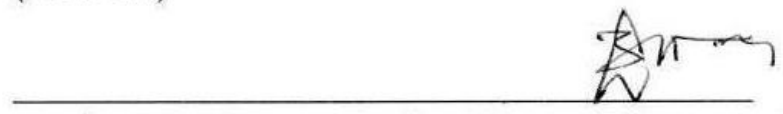

Profa. Dra. Norma Regina Truppel Constantino (UNESP/Bauru)

Coordenador e Presidente da Comissão de Pós-Graduação do Programa de PósGraduação em Arquitetura e Urbanismo: Prof. Dr. Tomás Antonio Moreira. 



\section{AGRADECIMENTOS}

À minha orientadora, a professora Luciana Schenk, pelo conhecimento compartilhado, e por sempre me incentivar no percurso de pesquisa.

Ao Conselho Nacional de Desenvolvimento Científico e Tecnológico (CNPq) pelo auxílio financeiro concedido.

Ao Instituto de Arquitetura e Urbanismo (IAU - USP, São Carlos), aos professores e funcionários que deram suporte ao desenvolvimento deste trabalho, e aos colegas pesquisadores do grupo de pesquisa YBY. Agradeço também aos companheiros de pósgraduação, Gabriel, Jéssica, Maria Cecília e Thaís pela amizade e parceria nas disciplinas e nos eventos científicos.

Ao Grupo de Trabalho dos Parques Urbanos de São Carlos (GTPU), grupo do qual tive a oportunidade de participar, e que enriqueceu o processo de pesquisa.

À professora Renata Bovo Peres por me receber em suas disciplinas no Programa de Pós-Graduação em Ciências Ambientais da Universidade Federal de São Carlos, que contribuíram muito para este trabalho.

À Renata Nanya pela amizade e que mesmo à distância sempre se fez muito presente. Obrigada pelo carinho, pelas conversas e pelo apoio.

À Camila pela amizade, pelos conselhos e por todo suporte ao trabalho de mestrado.

À Daniela pela amizade, e por abrir sua casa em São Carlos para me receber durante os anos de mestrado.

Aos meus avós Therezinha e Irineu, por compreenderem a minha ausência nos almoços de domingo. Obrigada pela torcida e por todo carinho.

Aos meus pais, Justina e Antonio, pelo amor incondicional e por serem a minha base. Eterna gratidão por tudo que fazem por mim. 



\section{RESUMO}

PIRES, Ana Carolina da Fonseca. Planejar com a Paisagem: potenciais espaços livres para um Sistema em São Carlos. Dissertação (Mestrado). Instituto de Arquitetura e Urbanismo, Universidade de São Paulo, São Carlos, 2020.

Esta pesquisa tem por objetivo propor um Sistema de Espaços Livres (SEL) para São Carlos, uma cidade que apresenta diversos espaços livres e conflitos socioambientais resultantes do seu processo de desenvolvimento urbano. Os espaços livres de um território apresentam relevância na minimização deste conflito por desempenharem múltiplas funções como as relacionadas à infraestrutura urbana, à proteção de ecossistemas, bem como aquelas referentes à sociabilidade. O SEL articula a variedade de espaços livres presentes em uma paisagem por meio de uma estratégia metodológica para Planejar com a Paisagem, que reconheça oportunidades para estabelecimento deste sistema. Busca-se na historiografia as bases desta estratégia, principalmente no campo disciplinar da Arquitetura da Paisagem e no Planejamento Ecológico da Paisagem de McHarg, que procurou bases mais convergentes entre o desenvolvimento humano e natureza. A partir desse referencial teórico, realiza-se a leitura da paisagem e seus espaços livres por meio de cartografias que apresentam informações de diferentes naturezas sobre a cidade, na escala das microbacias hidrográficas urbanas, com a intenção de revelar potencialidades e limitações destes espaços para a proposição do SEL. Como forma de organizar o Sistema, os espaços livres são classificados em categorias fundamentadas no campo da Arquitetura da Paisagem, na legislação e nas especificidades de São Carlos. Apresenta-se a confrontação do SEL proposto na cartografia com a realidade dos espaços, visando agregar novas informações, que somadas à estratégia geral, procuram contribuir na consolidação de uma metodologia de compreensão dos espaços livres urbanos e seu planejamento e projeto.

Palavras-chave: Planejar com a Paisagem; Sistema de Espaços Livres; São Carlos. 



\section{ABSTRACT}

PIRES, Ana Carolina da Fonseca. Planning considering the Landscape: potential open spaces for a System in São Carlos. Master dissertation. Instituto de Arquitetura e Urbanismo, Universidade de São Paulo, São Carlos, 2020.

This research aims to propose an Open Spaces System for São Carlos, a city that presents several open spaces and social-environmental conflicts resulted from its urban development process. Territory open spaces are relevant to minimize this conflict as they perform multiple functions such as those related to urban infrastructure, ecosystems protection, as well as those related to sociability. Open Spaces System articulates the variety of open spaces presented in the landscape through a methodological strategy for Planning considering the Landscape, which recognizes the opportunities for establishing this system. We intend to seek for the strategy bases in the historiography, mainly in the Landscape Architecture field and McHarg's Ecological Landscape Planning, which sought for more convergent bases between human development and nature. Based on this theoretical framework, the landscape and its open spaces are analyzed through cartographies, which presents different kinds of information about the city, on urban watersheds scale, with the purpose of revealing open spaces potentialities and limitations for Open Spaces System proposition. As a way of organizing the system, the open spaces are categorized based on Landscape Architecture field, legislation, and São Carlos specificities. it is presented the confrontation between Open Spaces System cartography and spaces reality, aiming to provide new information, and which added to general strategy, that can contribute to consolidate a methodology comprehension of open urban spaces and their planning and design.

Key words: Planning considering the Landscape; Open Spaces System; São Carlos. 



\section{LISTA DE FIGURAS}

Figura 1: Foto da Avenida Champs-Elysées em Paris, um típico boulevard.

Figura 2: Esquema dos grandes trabalhos de Haussmann em Paris: em preto, as ruas novas; em quadriculado, os novos bairros; em traços diagonais, os espaços verdes, com destaque para os dois grandes parques da cidade, o Bois de Boulogne (à esquerda) e o Bois de Vincennes (à direita). ....... 27

Figura 3: Sistema de Parques em Boston - Emerald Necklace.......................................................... 29

Figura 4: Diagrama no 7 - Agrupamento de Cidades Jardim. 35

Figura 5: à esquerda, Diagrama no 2 - A Cidade Jardim e seu entorno rural. À direita, Diagrama no 3, detalhe mostrando a distribuição dos espaços verdejados e a organização da Cidade Jardim. 36

Figura 6: Plano para Grande Londres - Mapa dos Quatro Anéis. Zonas concêntricas com características específicas que formam a região metropolitana da Grande Londres: Anel Interior (partindo da cidade), Anel Suburbano (passando pela área do condado), Cinturão Verde, Anel Externo.

Figura 7: Plano para Grande Londres - Conexões. Mapa do Sistema de Vias Arteriais.

Figura 8: Plano para Grande Londres - Mapa do Sistema de Espaços Livres. 46

Figura 9: Plano para Grande Londres - Mapa do Sistema de Trilhas.

Figura 10: Cartografias indicando a leitura da região para a Richmond Parkway. Obstáculos fisiográficos: Mapa de declividade, Mapa de drenagem superficial, Mapa de drenagem do solo, Mapa do leito rochoso, Mapa de base rochosa, Mapa de susceptibilidade à erosão.

Figura 11: Mapa síntese: Obstáculos fisiográficos. 59

Figura 12: Cartografias indicando a leitura da região para a Richmond Parkway. Valores: Mapa de valores do solo, Mapa de valores históricos, Mapa de valores cênicos, Mapa de valores recreativos, Mapa de valores residenciais, Mapa de inundação por marés, Mapa de valores hídricos, Mapa de valores florestais, Mapa de valores de fauna e flora, Mapa de valores institucionais. 60

Figura 13: Mapa síntese: O conjunto dos valores sociais. 60

Figura 14: Cartografia indicando a melhor localização para a Richmond Parkway. 61

Figura 15: Representação das características hidrológicas e fotografias que compõem a leitura da região metropolitana da Filadélfia.

Figura 16: Aspectos dominantes do processo natural, ordenados conforme seu valor e sua resistência a utilização humana; e hierarquia da idoneidade para uso urbano para o sistema de espaços livres na região metropolitana da Filadélfia.

Figura 17: Cartografia síntese indicando características hidrológicas e características do solo da região metropolitana da Filadélfia. 
Figura 18: Sobreposição dos meandros originais (pontilhado) do rio Don antes da urbanização.

Figura 19: Plano estratégico para a parte baixa do rio Don, indicando as três unidades paisagísticas distintas.

Figura 20: Fotografia do cenário existente à montante do rio Don, junto aos pântanos de Rosedale. Desenho ilustrando o mesmo trecho com as propostas para o pântano, os prados, os passeios e as áreas recreativas.

Figura 21: Plano de Expansão da cidade Santos, elaborado por Brito

Figura 22: Canais de drenagem pluviais a céu aberto elaborados por Brito para Santos

Figura 23: Desenho urbano, elaborados por Brito para Santos.

Figura 24: Localização e perímetro urbano do município de São Carlos, SP.

Figura 25: Mapa de localização do município de São Carlos quanto as bacias hidrográficas.

Figura 26: Principais córregos da sub bacia hidrográfica do córrego Monjolinho

Figura 27: Uma das primeiras cartografias de São Carlos

Figura 28: Rua São Carlos (atual avenida São Carlos) atravessando o córrego Gregório.

Figura 29: Praças na avenida São Carlos na década de 1940: Coronel Salles à esquerda e Jardim Público à direita.

Figura 30: Enchentes na área central de São Carlos

Figura 31: Principais eixos de expansão no período 1930-1959 e crescimento da área urbana.

Figura 32: Construção das vias marginais no córrego do Gregório.

Figura 33: Vista aérea do centro de São Carlos em 1974, onde se observa o Córrego Gregório parcialmente tamponado, os espaços livres, e os primeiros prédios.

Figura 34: Mapa dos parcelamentos realizados entre os anos 1857-1977. 138

Figura 35: Mapa da Expansão Urbana de São Carlos 140

Figura 36: Mapa do Zoneamento do Município de São Carlos. 144

Figura 37: Mapa das Áreas Especiais de Interesse Ambiental do Município de São Carlos. 146

Figura 38: Mapa de localização das APREMs. 150

Figura 39: Mapa das Criticidades. 152

Figura 40: Mapa da localização dos reservatórios e canais. 153

Figura 41: Mapa do Macrozoneamento Municipal. 157 
Figura 42: Mapa do Zoneamento Urbano.

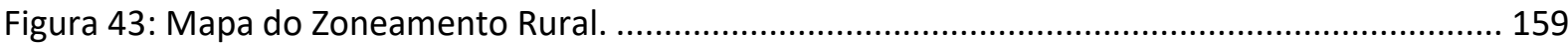

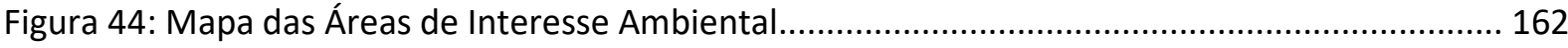

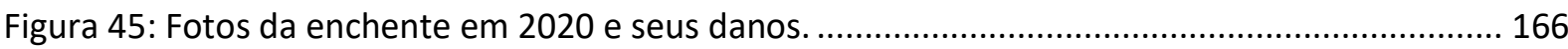

Figura 46: Funções dos Espaços Livres Urbanos de acordo com normas californianas. .................... 206

Figura 47: Parques de Conservação: 1) Sítio do Melo; 4) Parque do Monjolinho-Espraiado; 3) Córrego Água Quente (a numeração indica a localização no mapa 13) ......................................................... 222

Figura 48: Parques Lineares: 10) Córrego Santa Maria; 11) Córrego Cambuí (a numeração indica a

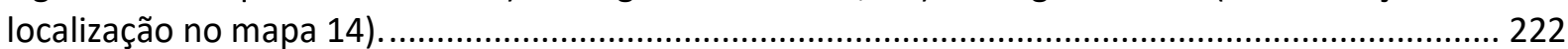

Figura 49: Parques Urbanos: 1) Parque Bicão; 4) Parque Kartódromo (a numeração indica a localização no mapa 15).

Figura 50: Praças: a esquerda, Praça Coronel Salles no centro da cidade; a direita, Praça no bairro J. Santa Paula.

Figura 51: Cartografia quente (observações sobre os espaços, divididas por trechos, e vistas relevantes).

Figura 52: Planta baixa Projeto Orla do Monjolinho

Figura 53: Planta baixa Projeto Orla do Monjolinho 230

Figura 54: Perspectivas do Projeto Orla do Monjolinho. 230 


\section{LISTA DE MAPAS}

Mapa 1: Imagem de São Carlos, Hidrografia, Microbacias Hidrográficas, Macrozoneamento Municipal.

Mapa 2: Imagem de São Carlos, Hidrografia, Microbacias Hidrográficas

Mapa 3: Imagem de São Carlos, Hidrografia, Principais Vias, Principais Rodovias, Estradas de Ferro. 185

Mapa 4: Imagem de São Carlos, Hidrografia, Linhas de Ônibus, Polos de Atração de Tráfego 186

Mapa 5: Imagem de São Carlos, Hidrografia, Ciclovias Implantadas, Ciclovias Previstas, Vias Compartilhadas; Rotas Ciclistas. 188

Mapa 6: Imagem de São Carlos, Hidrografia, Equipamentos de Educação, Saúde, Lazer e Assistência Social; Edifícios Históricos. 190

Mapa 7: Imagem de São Carlos, Hidrografia, Pontos de Alagamentos, Curvas de Nível. 192

Mapa 8: Imagem de São Carlos, Hidrografia, Áreas de Especial Interesse Ambiental, Subárea de Preservação 1 (SAPRE 1) e Subárea de Preservação 2 (SAPRE 2), Reserva Legal.

Mapa 9: Imagem de São Carlos, Hidrografia, Sistema de Recreio, Áreas Institucionais. 195

Mapa 10: Imagem de São Carlos, Hidrografia, Parques Existentes, Parques do Decreto, Parque adicionado (Jd. Embaré).

Mapa 11: Síntese para a proposição do Sistema de Espaços Livres. 200

Mapa 12: Sistema de Espaços Livres para São Carlos 219

Mapa 13: Parques de Conservação do Sistema de Espaços Livres de São Carlos

Mapa 14: Parques Lineares do Sistema de Espaços Livres de São Carlos

Mapa 15: Parques Urbanos do Sistema de Espaços Livres de São Carlos.

Mapa 16: Praças do Sistema de Espaços Livres de São Carlos.

Mapa 17: Recorte do Mapa Síntese que apresenta parte da microbacia do Córrego Monjolinho, trecho parque Kartódromo até as proximidades da rodovia Washington Luiz, e o percurso realizado. 


\section{SUMÁRIO}

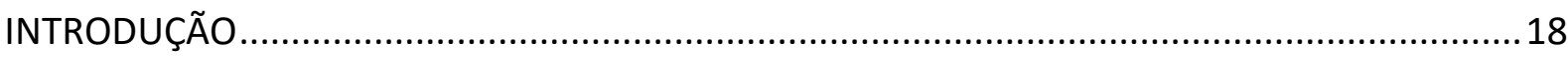

1 SOLUÇÕES PRECURSORAS E A TRAJETÓRIA DO PLANEJAMENTO COM PAISAGEM .........22

1.1 Parques na cidade industrial: a experiência de Haussmann em Paris ................................. 22

1.2 Planejamento com a Paisagem: o pioneirismo de Olmsted ............................................ 27

1.3 A natureza estruturando o planejamento da cidade: as propostas de Forestier e Howard. 30

1.4 As ressonâncias do modelo Cidade Jardim: Abercrombie e seu Plano para a Grande Londres 38

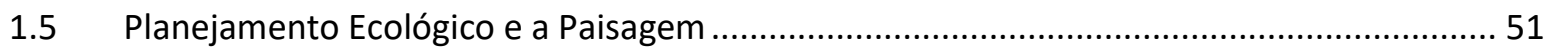

1.6 Ressonâncias do Planejamento Ecológico de lan McHarg ................................................. 65

2 PLANEJAMENTO URBANO BRASILEIRO E A PAISAGEM ................................................. 78

2.1 Obras de saneamento e embelezamento e suas consequências .......................................... 79

2.2 A visão da cidade como totalidade: planos tecnicistas como solução dos problemas urbanos 90

2.3 Constituição de um corpo legal para ordenar a expansão urbana ...................................... 98

$2.4 \quad$ Lógicas que orientam as Políticas Urbanas e Ambientais ................................................. 108

2.5 Aproximações da gestão urbana e ambiental............................................................. 114

3 SÃO CARLOS E SEU PROCESSO DE URBANIZAÇÃO: DESENVOLVIMENTO, CONFLITOS E

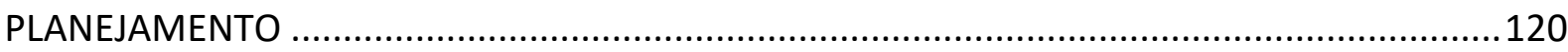

3.1 A construção do conflito entre o desenvolvimento urbano e o meio físico e a formação dos

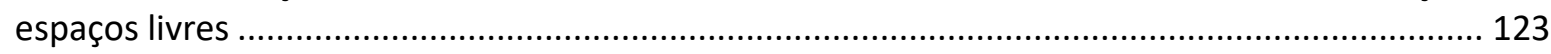

3.2 A questão ambiental e o planejamento urbano ............................................................. 139

4 PLANEJAR COM A PAISAGEM: UM SISTEMA DE ESPAÇOS LIVRES PARA SÃO CARLOS... 168

4.1 Uma Estratégia Metodológica para Planejar com a Paisagem ......................................... 175

4.2 Levantamento de Categorias para um Sistema de Espaços Livres .................................... 201

4.3 Elaboração das categorias para o Sistema de Espaços Livres de São Carlos ....................... 214

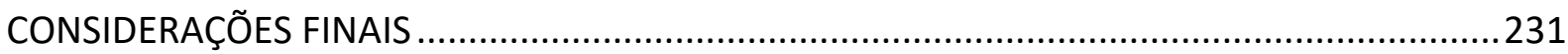

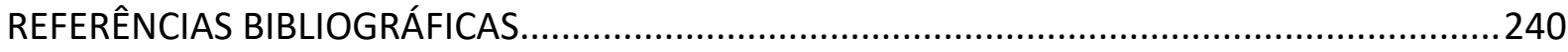




\section{INTRODUÇÃO}

Diante do cenário atual em que muitas cidades apresentam ampliação em suas taxas de crescimento, por vezes não acompanhada de um planejamento adequado, é frequente a ocorrência de problemas urbanos ambientais como enchentes, deslizamentos, ilhas de calor etc. Ao modificar e moldar as paisagens, o modelo tradicional de planejamento e de gestão urbana associado aos interesses de mercado, muitas vezes desconsidera as características do ambiente natural, seus processos e o contexto histórico e cultural. Como consequência, sucedeu-se grande impacto sobre o ambiente, implicando situações de risco para a população, bem como o afastamento entre o ser humano e a natureza. Planejar com a Paisagem, fio condutor desta dissertação, pretende abranger elementos desconsiderados pelo planejamento urbano tradicional ou tratados de maneira fragmentada pelos planos territoriais.

Paisagem é um termo polissêmico que articula as dimensões relacionadas à materialidade, à experiência no ambiente, à temporalidade, aos processos naturais e humanos, entre outros. Os problemas de configuração dos espaços urbanos e de apropriação da natureza referem-se à paisagem, que pode ser descrita como a fisionomia resultante do uso e ocupação do solo, isto é, produto e meio das relações entre o suporte físico e as intervenções antrópicas (SANTOS, 2003).

As questões que usualmente são conflituosas no desenvolvimento urbano e que envolvem os processos naturais (geológico, hidrológico e biológico etc.) e os processos humanos (socioeconômico e cultural) são objetos desta investigação que planeja com a paisagem. Os espaços livres de um território, ou seja, aqueles sem a presença de edificações, verdejados ou não (MAGNOLI, 1982), apresentam papel significativo na minimização deste conflito por desempenharem múltiplas funções, desde aquelas relacionadas à infraestrutura urbana (circulação, drenagem, lazer etc.), até aquelas relacionadas ao conforto térmico, à conservação e proteção de ecossistemas, bem como aquelas referentes à sociabilidade e à experiência estética. Deste modo, os espaços livres de uma paisagem deixam de ter caráter residual, fruto de exigências quantitativas referentes à legislação sobre parcelamento do solo 
e que não se desdobram em qualidade da paisagem, para, então, reivindicar o papel de protagonistas, participando ativamente da organização urbanística (TARDIN, 2008).

A abordagem sistêmica dos espaços livres é pertinente frente à multiplicidade presente na temática da paisagem, assim é possível pensar em interconexões físicas e funcionais, uma vez que estes espaços estabelecem relações entre si e, mesmo sem conexão física, afetam-se reciprocamente. O Sistema de Espaços Livres (SEL) busca estratégias para articular os fragmentos de espaços livres em diversas escalas e com diversas funcionalidades, qualificações estéticas e fundiárias (QUEIROGA, 2011).

A cidade de São Carlos, localizada no interior do Estado de São Paulo, apresenta um tecido urbano descontínuo, assim conformado especialmente a partir da década de 1980, resultado de escolhas de planejamento e de flexibilização das legislações. Este percurso foi caracterizado pela construção de diversos conflitos socioeconômicos e ambientais. Uma consequência dessas escolhas é a existência de muitos espaços livres, potenciais geradores de um sistema que reúna questões associadas à manutenção dos processos naturais, à infraestrutura, à mobilidade, ao lazer e à sociabilidade.

Deste modo, visando oferecer uma alternativa ao planejamento territorial tradicional, propõe-se um Sistema de Espaços Livres para a São Carlos, a partir de uma estratégia metodológica para Planejar com a Paisagem. Descreve-se esta estratégia que se fundamenta no campo disciplinar da Arquitetura da Paisagem e dialoga com a complexidade intrinsicamente ligada à paisagem.

Dado que grande parte dos problemas urbanos ambientais nesta cidade é decorrente do conflito com a rede hídrica, adota-se as microbacias hidrográficas urbanas como recorte territorial para a leitura e planejamento da paisagem. A bacia hidrografia apresenta potencial para articular elementos urbanos e ambientais no planejamento do território, deste modo, no presente trabalho, a utilização desta unidade de planejamento visa orientar a expansão urbana em congruência com processos naturais.

A leitura da paisagem e seus espaços livres é realizada por meio de cartografias temáticas sobre a cidade, analisadas com auxílio da tecnologia do Sistema de informações Geográficas (SIG) e com a finalidade de revelar potencialidades e limitações destes espaços para a proposição do SEL. Os espaços livres do Sistema são classificados em categorias, que 
pretendem agrupar elementos afins para organizar o SEL e, assim facilitar a elaboração de regulamentos, planos e programas adequados para cada conjunto de espaços com a intenção de efetivação da proposta. As categorias são fundamentadas a partir da relação entre os conceitos do campo disciplinar da Arquitetura da Paisagem, da legislação e das especificidades de São Carlos.

O capítulo 1 apresenta a constituição do campo disciplinar da Arquitetura da Paisagem em âmbito internacional, em meados do século XIX, momento de intensa industrialização e urbanização, quando as grandes cidades, especialmente as europeias e as norte-americanas, encontravam-se congestionadas e com graves problemas relacionados à saúde pública. A inserção de espaços verdejados ocorreu na tentativa de promover, inicialmente, salubridade e embelezamento e, posteriormente, recuperação da qualidade de vida e estruturação da cidade. Apresentam-se as soluções dadas pelos precursores do planejamento com a paisagem aos impactos negativos da urbanização, bem como a ressonância destas propostas no planejamento contemporâneo. Destacam-se o pioneirismo de Frederick Law Olmsted, lançando as bases da Arquitetura da Paisagem na viragem do século XIX para o XX, e a contribuição também pioneira de lan McHarg em meados do século XX para o Planejamento Ecológico da Paisagem, que pretendeu constituir a potencial congruência entre desenvolvimento humano e natureza.

O capítulo 2 mostra os contatos do planejamento urbano brasileiro com a Arquitetura da Paisagem, dado que esse campo estava se constituindo internacionalmente no período analisado (final do século XIX e a primeira metade do século XX) e, no Brasil, observam-se apenas permeabilidades a uma das dimensões da paisagem, a temática ambiental. Tendo em vista o fio condutor deste trabalho, Planejar com a Paisagem, na primeira parte do capítulo, constrói-se historicamente uma narrativa sobre as propostas de planejamento urbano que de alguma forma incorporaram a natureza física e seus atributos, inicialmente sob o viés estético, passando por considerações técnicas e, finalmente, sob orientação ambiental-ecológica. $\mathrm{Na}$ segunda parte procura-se compreender quais são as lógicas que conduzem as políticas urbanas e as políticas ambientais, especialmente quanto à abordagem dos espaços livres. Em seguida busca-se aproximações entre gestão urbana e gestão ambiental, especificamente quanto aos recursos hídricos que, através da Política Nacional de Recursos Hídricos (Lei 
Federal no 9.433/1997), reconheceu a bacia hidrográfica como unidade de planejamento e gestão por seu potencial em articular a questão ambiental e o uso e ocupação do solo.

No capítulo 3 apresenta-se a cidade de São Carlos, seu processo de urbanização e desenvolvimento para compreensão da conformação de seus espaços livres e do conflito com o meio físico, apontando quais foram as consequências deste desenvolvimento. Observa-se de que maneira os espaços livres estão sendo abordados pelo planejamento urbano e como a temática ambiental se insere na legislação municipal.

O capítulo 4 caracteriza e aprofunda uma estratégia metodológica para Planejar com a Paisagem que vem sendo desenvolvida em uma disciplina do curso de Arquitetura e Urbanismo da Universidade de São Paulo (IAU-USP) e aprofundada pelo Grupo de Trabalho e de Planejamento dos Parques Urbanos de São Carlos (GTPU), objetivando a proposição de um Sistema de Espaços Livres para a cidade. Essa estratégia baseia-se no campo disciplinar da Arquitetura da Paisagem e caracteriza-se: pela complexidade, intrinsicamente ligada a polissemia da Paisagem; pela transversalidade, entre os campos do conhecimento e entre os agentes na produção do espaço urbano; pelo cruzamento de informações de diferentes naturezas; e pelo trânsito de escalas, do sobrevoo (cartografias no recorte das microbacias hidrográficas da Macrozona Urbana) ao fenômeno (recorte de uma microbacia hidrográfica urbana específica). O cruzamento de informações de diferentes naturezas contempla cartografias a respeito das características físicas, das legislações, dos conflitos, das presenças e das dinâmicas da cidade na escala das microbacias hidrográficas urbanas. Promove-se a leitura da paisagem e seus espaços livres e a classificação destes espaços, mirando protegêlos ou qualificá-los. Descreve-se ainda outra parte da estratégia metodológica, o trânsito de escalas, que ocorre através de visitas a campo que tem por objetivo a confrontação das informações contidas nas cartografias do sobrevoo com a realidade dos espaços, para a apreensão de novos dados que auxiliem na construção do programa de projeto dos espaços livres.

O trabalho se inscreve nesse esforço contemporâneo de produção de alternativas de planejamento e projeto dos espaços livres, procurando atualizar chaves históricas do campo disciplinar da Paisagem que contemplam a associação entre infraestrutura urbana e espaços de sociabilidade. 


\section{SOLUÇÕES PRECURSORAS E A TRAJETÓRIA DO PLANEJAMENTO COM PAISAGEM}

\subsection{Parques na cidade industrial: a experiência de Haussmann em Paris}

As transformações técnicas, sociais e urbanas ocasionadas pela Revolução Industrial delinearam configurações de cidades que atenderam às novas demandas econômicas. Foi em meados do século XIX que as grandes cidades europeias, que passaram por um processo de intensa industrialização e urbanização, vivenciaram mais fortemente o impacto dessas transformações sobre o meio ambiente natural e sobre as condições de vida urbana. Os avanços técnicos gerados pela Revolução Industrial impulsionaram a formação da cidade moderna ao mesmo tempo em que estabeleceram problemas.

Foi a partir da Primeira Revolução Industrial (final do século XVIII e início do século XIX), cujos avanços tecnológicos e implicações socioambientais seriam ainda ampliados na chamada Segunda Revolução (segunda metade do século XIX), que os impactos do modo de vida urbano se tornaram notórios. O aprimoramento dos meios de produção e a exploração dos recursos naturais proporcionaram um salto quantitativo e qualitativo na produção de bens e serviços, o que associado a uma melhora geral dos padrões alimentares contribuiu, em um primeiro momento, para o aumento da qualidade de vida. Nas áreas rurais, o desenvolvimento do capitalismo industrial também provocou alterações através da mecanização, utilização de novas tecnologias na agricultura e da criação intensiva de animais, o que aperfeiçoava a produção, mas contribuía, ao mesmo tempo, para o êxodo rural. 0 aumento do número de indústrias e, portanto, da oferta de trabalho, atraía para as cidades cada vez mais pessoas. A população urbana cresceu enormemente, devido à diminuição da mortalidade e às constantes migrações campo-cidade. Em um ciclo para produzir mais bens manufaturados e ampliar os serviços para atender uma população cada vez maior, as cidades industriais cresceram rapidamente, essa lógica acabou acarretando em situações de convívio social e de higiene pública calamitosas, principalmente para a classe operária, e no 
desaparecimento de áreas verdes nas grandes cidades que se industrializavam (BENEVOLO, 2012).

As estruturas das antigas cidades não suportavam seu adensamento, configurando-se em ruas estreitas e tortuosas sem condições adequadas de higiene e salubridade. Além de serem submetidos às extensas jornadas de trabalho nas indústrias e aos baixos salários, os operários vivenciaram intensamente um cenário no qual dividiam miseráveis moradias, sem ventilação e iluminação adequadas ${ }^{1}$. Os espaços verdes existentes - jardins, bosques - foram ocupados por novas construções como casas e barracões industriais. Em decorrência desse panorama insalubre, as epidemias tornaram-se comuns, atingido inclusive as classes abastadas, que partiram em direção às bordas da cidade em busca de melhores condições de vida. Nesse movimento, a periferia se transforma em uma somatória de bairros de classe alta, bairros operários e indústrias. (BENEVOLO, 2012).

Assim, as cidades que cresceram sob a égide de uma economia liberal seguiam a racionalidade dos interesses capitalistas, faltando-Ihes a atuação do Estado como mediador das relações sociais, econômicas e políticas (BENEVOLO, 2012). O congestionamento urbano, resultante do aumento populacional, acompanhou o modelo capitalista de produção, cuja busca constante e ilimitada por recursos acarretava enorme impacto sobre o ambiente natural ${ }^{2}$.

A falta de qualidade de vida nas metrópoles, especialmente nas cidades europeias, resultante do modelo de crescimento fundamentado primordialmente em questões de caráter econômico, gerou a necessidade de buscar formas de organização do espaço urbano. Nesse contexto, o urbanismo nascente era discutido por profissionais de vários campos do conhecimento - médicos, engenheiros, arquitetos, administradores - e os primeiros projetos de reforma urbana apresentaram uma matriz higienista e uma perspectiva de reordenamento físico e social.

\footnotetext{
1 “[...] no século XIX a Revolução Industrial deixou outras profundas e bem conhecidas marcas nas cidades europeias: pelo inédito aumento de suas populações, da poluição do ar e dos cursos d'água, de graves problemas de higiene e consequentemente da enorme deterioração do ambiente urbano. É na habitação dos operários e da massa sem-trabalho que se vê obrigada a deixar o campo e as cidades de pequeno porte para procurar melhor sorte, que os resultados são contundentes." (OTTONI, 1996, p. 18).

${ }^{2}$ A localização das primeiras indústrias desse período estava atrelada a disponibilidade de recursos naturais (cursos d'água, bosques, jazidas de minérios etc.) nas proximidades, não havendo preocupação com uso consciente destes.
} 
Autores como Benevolo (2001) e Spirn (1995) referem-se à cidade dessa época como um organismo doente, que necessitava curar os males advindos da intensa industrialização e urbanização. A inserção de espaços verdes seria um dos "remédios" para tornar a cidade mais salubre, tanto que são referidos como "pulmões da cidade". Nesse primeiro momento, a natureza foi incorporada ao tecido urbano na forma de parques, jardins, praças e ruas arborizadas na tentativa de trazer mais equilíbrio ao desenvolvimento.

Anteriormente a esse período - até meados do século XVIII - a natureza comparecia nas cidades europeias na forma de praças e jardins privados, ligados às residências de classes abastadas. Posteriormente, com as reformas sanitaristas, a municipalidade passou a incorporá-los para o uso público. Spirn (1995) afirmou que enquanto as cidades eram relativamente pequenas, ainda mantinham relações funcionais e visuais com o campo e com a natureza.

À medida que as cidades se tornaram maiores e mais congestionadas, a distância do campo e a nostalgia da natureza aumentaram, enquanto queixas contra a vida urbana - especialmente a fumaça e o mau cheiro - se multiplicaram. Isso foi tão verdadeiro para Roma do século I, como para Londres do século XVI e Nova lorque do século XX. No século XVII, na Europa, a propriedade de um jardim e a facilidade de acesso ao campo, anteriormente privilégio de todo cidadão, tornaram-se inacessíveis ao morador comum. Onde antes havia pomares nos quintais e jardins foram construídas casas, servidas por vielas escuras atrás das ruas principais. No século XVIII, os muitos jardins de Colônia e da maioria de outras cidades europeias desapareceram. (SPIRN, 1995, p. 47).

Na segunda metade do século XIX, a regulação da expansão urbana ocorreu através da atuação do Estado. Desta forma, além da inserção de espaços verdes, foram criadas regras construtivas municipais para melhoramentos nas edificações, como o controle sobre altura dos edifícios ou composição dos elementos das fachadas que, no entanto, não se reverteram em melhorias significativas nas áreas mais densas e nas áreas ocupadas pelas classes menos privilegiadas, à exemplo das transformações parisienses, como será exposto mais adiante. Entre 1830 e 1850 as primeiras leis sanitárias começaram a ser discutidas e, de acordo com Benevolo (2001), constituíram a base sobre a qual se construiu a legislação da urbanística contemporânea.

$\mathrm{Na}$ França, tais leis tiveram papel fundamental nas reformas urbanas e se transformaram em instrumentos de poder na figura da nova direita autoritária e popular, o 
imperador Napoleão III (1808-1873). Em 1852, ao assumir o governo, Napoleão III considerou ser necessário controle direto do Estado sobre muitos setores da vida econômica e social, desta forma, efetuou uma série de reformas com caráter contrarrevolucionário ${ }^{3}$, na qual a urbanística figurava como instrumento eficaz de ação (GRAVAGNUOLO, 1998). Napoleão III nomeou para prefeito de Paris, o Barão Georges-Eugène Haussmann ${ }^{4}$ (1809-1891), considerado um colaborador preparado para colocar em prática sua ambiciosa ideia de transformação de Paris.

A reestruturação de Paris visou proporcionar basicamente o que cada vez mais falta fazia às cidades que se industrializavam rapidamente: melhor circulação para pessoas e mercadorias; inserção eficiente no espaço urbano de edifícios que abrigam novas necessidades trazidas pela cidade da era industrial e sua crescente população (estações ferroviárias, mercados, edifícios administrativos, hospitais, exposições, salas de espetáculos, lojas de departamento etc.); espaços abertos e verdes para melhorar a salubridade da cidade e o lazer de sua população; provisão de água e esgotos eficientes, evitando a proliferação de doenças e dos constantes surtos de cólera; e, no caso especial de Paris, providenciar rapidez e segurança no acesso das tropas a qualquer lugar onde ocorresse sublevação. (OTTONI, 1996, p. 32).

As reformas implantadas por Haussmann nesse período (1853-1869) seguiam os conceitos higienistas e tinham o objetivo principal tornar Paris a cidade mais moderna do mundo. As obras fundamentavam-se em melhorar a circulação através da abertura de largas avenidas arborizadas, os elegantes boulevards (figura 1), adicionando espaços verdes e demolindo as edificações precárias e cortiços, o que garantiu não só a salubridade e o embelezamento, como também promoveu o afastamento da pobreza do centro da cidade. Para tal feito, Haussmann contou com o apoio técnico de uma equipe de engenheiros de alto nível, dentre eles, Jean-Charles Adolphe Alphand (1817-1891), chefe do Services de Promenades et Plantations, que promoveu a execução dos parques públicos como o Bois de Vincennes, do jardim Buttes-Chaumont, além de cuidar da conservação do Bois de Boulogne e outros jardins, da arborização e dos equipamentos nos boulevards.

\footnotetext{
${ }^{3}$ Grandes obras públicas, como a abertura de ruas retilíneas para facilitar a repressão de futuras revoltas populares (BENEVOLO, 2001). Ver nota 6.

${ }^{4}$ G. E. Haussmann era funcionário público com experiência no cargo de administração quando foi nomeado para prefeito de Paris, a qual governou entre os anos 1853 e 1869, sendo considerado uma autoridade para empreender as grandes obras na cidade (BENEVOLO, 2001).
} 


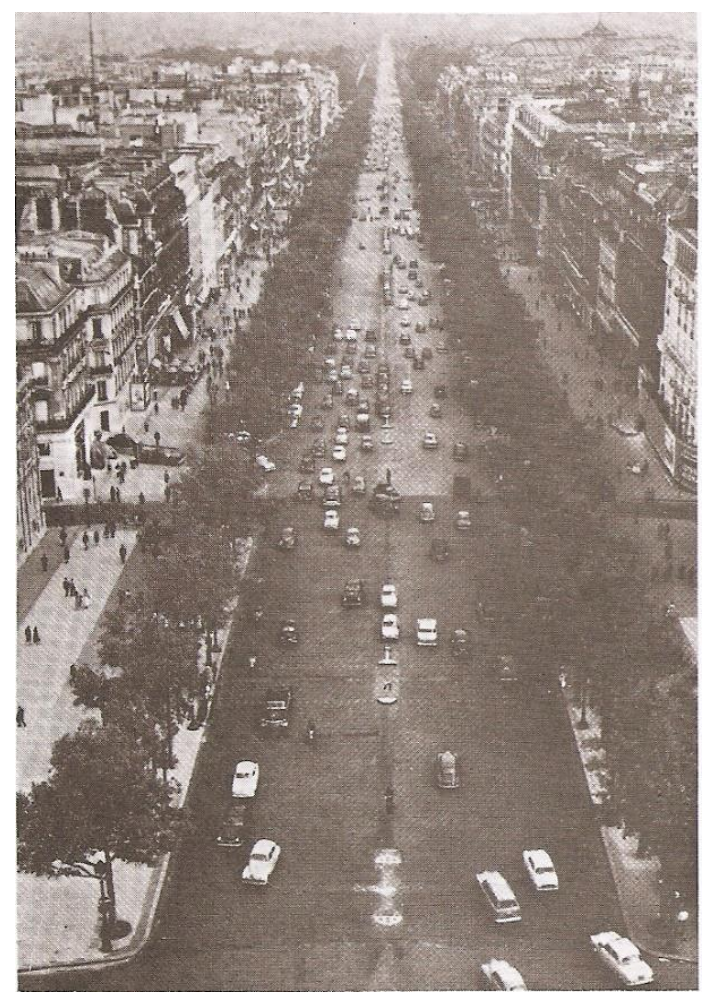

Figura 1: Foto da Avenida Champs-Elysées em Paris, um típico boulevard. Fonte: BENEVOLO, 2012, p. 601.

Deste modo, Paris ingressou no século XX sob a forma ${ }^{5}$ que lhe foi dada por Haussmann, com as reformas que visavam o embelezamento estratégico ${ }^{6}$ da metrópole através da substituição da Paris medieval por uma cidade burguesa extremamente planejada. Os chamados grands travaux (figura 2) foram possibilitados devido à centralização do poder, que permitiu criar os instrumentos necessários para sua realização (FORESTIER, 1997), como leis que viabilizaram expropriações de terrenos e imóveis para abertura de ruas e avenidas.

\footnotetext{
${ }^{5}$ Alguns autores têm uma posição crítica em relação às obras de Haussmann e consideram que ele apagou a memória histórica de Paris e criou uma cidade artificial de arquitetura homogênea (BENEVOLO, 2001).

${ }^{6}$ As ruas largas e avenidas arborizadas construídas sob o pretexto de embelezar e modernizar a cidade, tinham sobretudo o objetivo de impedir a insurreição dos populares em barricadas e propiciar o deslocamento mais efetivo das tropas militares (BENEVOLO, 2001). A discussão sobre o tema é extensa e também engloba questões socioeconômicas, como o fato dos mecanismos criados para as expropriações de terrenos e edifícios propiciarem a especulação imobiliária e valorização das áreas centrais desencadeando expansão metropolitana ilimitada ao deslocar as classes mais baixas para a periferia, marcando a segregação socioespacial. (GRAVAGNUOLO, 1998).
} 


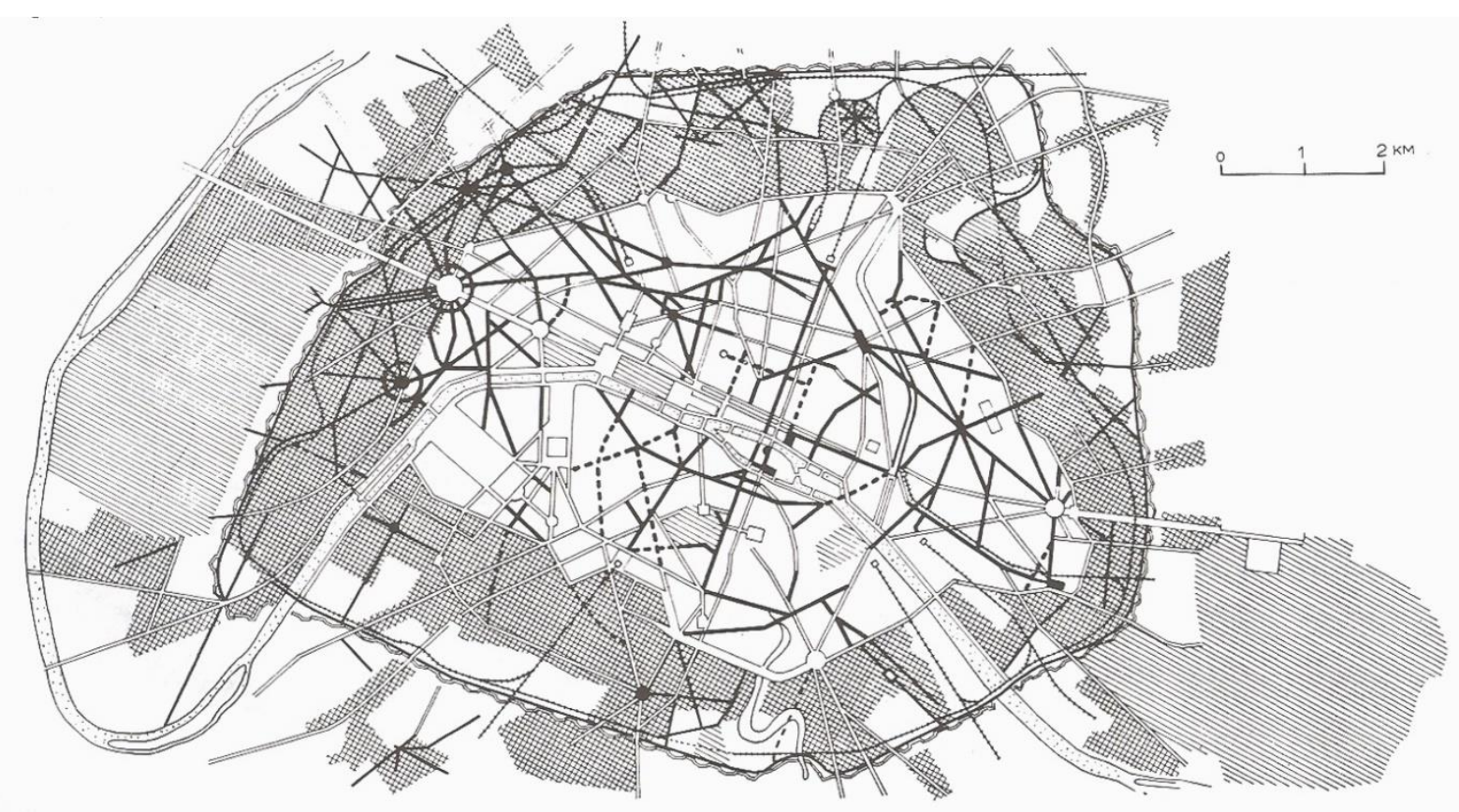

Figura 2: Esquema dos grandes trabalhos de Haussmann em Paris: em preto, as ruas novas; em quadriculado, os novos bairros; em traços diagonais, os espaços verdes, com destaque para os dois grandes parques da cidade, o Bois de Boulogne (à esquerda) e o Bois de Vincennes (à direita).

Fonte: BENEVOLO, 2012, p. 592.

O plano de Haussmann foi apontado por Benevolo (2001) como o primeiro com ações efetivas e capazes de acompanhar as transformações e necessidades da nascente cidade moderna. Ainda segundo este autor, as propostas haussmannianas tiveram êxito por algumas décadas do século XIX em virtude de garantirem espaços livres para expansão, mas que por serem limitados não acompanharam o desenvolvimento contínuo da cidade, tornando congestionada a Paris do século XX.

\subsection{Planejamento com a Paisagem: o pioneirismo de Olmsted}

Nos Estados Unidos também houve a preocupação em incorporar a natureza como questão relevante para garantir um desenvolvimento mais equilibrado às cidades que se industrializavam em meados do século XIX. Nesse contexto, Frederick Law Olmsted (18221903) se destacou lançando as bases da Arquitetura da Paisagem ${ }^{7}$ (Landscape Architecture)

\footnotetext{
${ }^{7}$ De acordo com Schenk (2008), em 1899 foi fundada a American Society of Landscape Architects, que contou com profissionais como arquitetos, jardineiros, superintendentes de parques, engenheiros, escritores e artistas em geral. O primeiro programa de graduação em Landscape Architecture foi implantado em 1900-1901 em Havard, sob a direção de Frederick Olmsted Junior.
} 
(SCHENK, 2008). Em sua obra, os espaços verdes inseridos na cidade garantiriam salubridade bem como orientariam sua expansão. Dessa forma, o Sistema de Parques (Park System) proposto por ele, consistia em uma rede de parques interligados pelas parkways, vias largas e bem sombreadas (semelhantes aos boulevards), que promoveriam um deslocamento agradável e determinariam a reestruturação do sistema viário e dos futuros eixos de desenvolvimento urbano (SCHENK, 2008). Para Olmsted, o parque era algo além de uma intervenção pontual, ele estaria vinculado à estrutura urbanística circundante por meio da implantação de suas vias de deslocamento.

Para a cidade de Boston, que no final do século XIX enfrentava problemas de drenagem decorrentes das excessivas modificações da paisagem, Olmsted apresentou um projeto que agregava os avanços técnicos aos valores estéticos da paisagem. O Sistema de Parques de Boston, conhecido como Emerald Necklace (Colar de Esmeraldas) (figura 3) originou-se da reformulação do Back Bay Fens, um pântano insalubre, que sofria com constantes enchentes. Olmsted projetou um sistema de drenagem aproveitando a condição natural do terreno para o descanso das águas, criando então bacias de contenção com tratamento paisagístico adequado, que armazenavam temporariamente as águas pluviais, evitando inundações no entorno (SPIRN, 1995). Segundo Schenk (2008, p. 124), a transformação do pântano em parque suscitou grande esforço técnico, que aliado ao princípio orgânico ${ }^{8}$ e à arte, reconstituíram as características naturais da paisagem. Ainda estavam em seus planos conectar a cidade aos seus subúrbios, articulando o parque aos outros espaços livres e, assim, transpondo a fronteira entre projeto da paisagem e planejamento urbano.

\footnotetext{
${ }^{8}$ Schenk (2008) refere-se à fruição da paisagem, através da combinação entre técnica e arte capazes de recuperar as características desta paisagem, de forma que o resultado parecesse um gesto simples, mas que despertasse uma experiencia estética nas pessoas.
} 


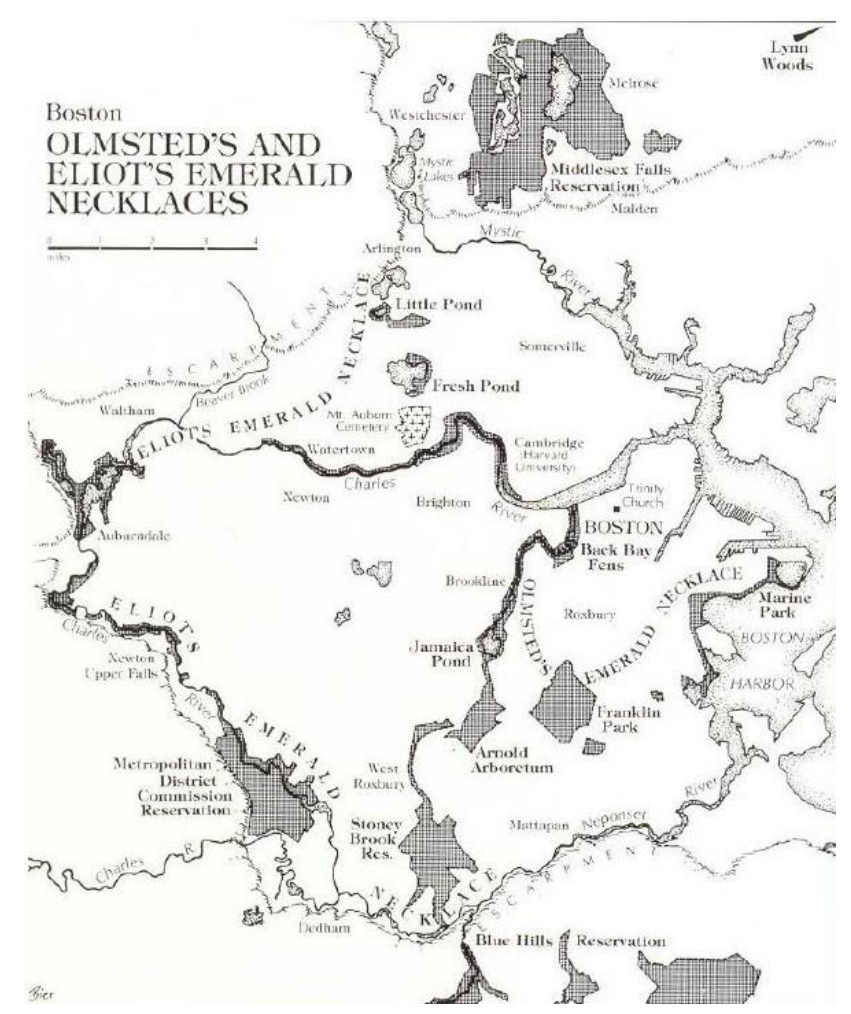

Figura 3: Sistema de Parques em Boston - Emerald Necklace.

Fonte: SCHENK, 2008, p. 125.

Walker e Simo (1994) consideram Olmsted um arquiteto da paisagem moderno, não em relação às características formais mais conhecidas desse movimento, mas em relação à forma como ele reagia com originalidade aos problemas em seu contexto sociocultural e político, assim como à realidade física do local.

Frederick Law Olmsted foi um arquiteto paisagista "moderno", por exemplo? Na medida em que estava respondendo de maneiras novas e apropriadas às condições - geográficas, sociológicas, tecnológicas, políticas, culturais e assim por diante - de seu local ou do ambiente em geral, ele era moderno. Mas em seu tratamento da forma pura e dos relacionamentos formais considerações que se tornariam cada vez mais significativas para a arte moderna - ele era um designer bastante tradicional e sofisticado. Olmsted tinha um amor romântico do século XIX por formas (e materiais) ricos, generosos e fluidos, que nunca deveriam ser percebidos por si mesmos, mas geralmente experimentados como cenário e apreciados em seu amplo contexto social e cultural. (WALKER; SIMO, 1994, p. XI, tradução nossa9).

\footnotetext{
9 "Was Frederick Law Olmsted a "modern" landscape architect, for instance? Insofar as he was responding in fresh, appropriate ways to the conditions - geographical, sociological, technological, political, cultural, and so on - of his site or of the larger environment, he was modern. But in his treatment of pure form and formal relationships - considerations that would become increasingly significant for modern art - he was a fairly traditional, sophisticated designer. Olmsted had a nineteenth-century romantic's love of rich, bounteous, flowing
} 
Olmsted tinha um conhecimento multidisciplinar e a compreensão sistêmica dos processos naturais, demonstrando em suas realizações os ganhos que grandes obras de infraestrutura podem obter quando a paisagem local não é renegada. $\mathrm{O}$ arquiteto defendia a preservação de áreas naturais, não somente para a diminuição dos problemas urbanos ambientais vivenciados pela moderna sociedade civil nascente nos grandes centros, como também para a recuperação da qualidade de vida. As áreas naturais seriam locais onde pessoas de diversas origens poderiam sociabilizar e promover um senso de comunidade (WALKER; SIMO, 1994).

De acordo com Schenk (2008), este arquiteto da paisagem valorizava a natureza tanto pelas questões estéticas quanto pela dimensão pedagógica e formativa que a experiência num parque poderia proporcionar, sendo dever da municipalidade garantir a existência desses espaços verdes para os cidadãos. Os parques elaborados por Olmsted em Boston foram concebidos como elementos articuladores de espaços verdejados vinculados à trama urbana, ganhando, assim, a escala da cidade na forma de um sistema que agregava diversas dimensões do Planejamento com a Paisagem.

\subsection{A natureza estruturando o planejamento da cidade: as propostas de Forestier e Howard}

O ideário Park System desenvolvido nos Estados Unidos foi explorado ${ }^{10}$ pelo engenheiro florestal ${ }^{11}$ Jean Claude Nicolas Forestier (1861-1930). Ele estava atento à realidade de ampliação do tecido urbano e preconizava enfrentá-lo através de um planejamento urbano que abrangesse os espaços livres, contemplando além das questões de salubridade e de estética, a organização da expansão urbana.

A maioria dos municípios das grandes cidades da América e da Europa percebeu o perigo em permitir que os espaços ainda livres fossem desperdiçados, em desfigurar os aspectos ainda interessantes ou pitorescos da cidade e seus arredores, em permitir que todas as saídas para o campo

\footnotetext{
forms (and materials) that were never meant to be perceived in their own right but, rather, generally experienced as scenery and appreciated in their broad social and cultural context."

${ }^{10}$ Forestier teve seu primeiro contato com o ideário americano de Park System em 1901, ocasião em que recebeu em Paris a Comissão Senatorial de Washington (COHEN in LECLERC, 1990).

${ }^{11}$ Forestier nasceu em 9 de janeiro de 1861 em Aix-les-Bains na França. Iniciou sua formação na École Polytechnique (1880-1882), depois estudou na École Libre des Sciences Politiques (1882-1883) e especializou-se na École Forestiere de Nancy (1883-1885) (LECLERC; CID in FORESTIER, 1997).
} 
fossem fechadas pelos subúrbios. Eles entenderam que elementos de higiene e beleza uma cidade em desenvolvimento pode encontrar ao longo de um século em espaços livres e em reservas numerosas e criteriosamente distribuídas.

Eles entenderam que o "plano da cidade" é insuficiente se não for complementado por um programa abrangente e um plano especial de espaços livres internos e externos para o presente e o futuro, por um sistema de parques. (FORESTIER, 1997, p. 56, tradução nossa ${ }^{12}$ ).

Forestier foi membro do Musée Sociall13, no qual pôde debater sobre as transformações da cidade aglomerada e participou da fundação de todas as instituições ${ }^{14}$ francesas relacionadas à história do urbanismo naquele período, sendo, portanto, figura essencial na constituição desse novo saber. O Urbanismo como disciplina autônoma teve origem no final do século XIX a partir de uma visão que cruzava diversos campos de conhecimento e que considerava a inserção dos espaços verdes no planejamento das cidades.

Apesar da relevância de Forestier na constituição do urbanismo francês, sua redescoberta na década de 1990 condiz com a consciência contemporânea de uma 'modernidade outra', período de criação, na França, de um corpus de referências sobre a história dos jardins e da paisagem. Assim, ele se instalou na tradição moderna aberta por Olmsted nos Estados Unidos e se aproximou dos outros profissionais até então também pouco conhecidos pelos historiadores.

De acordo com Leclerc e Cid (in FORESTIER, 1997) Forestier teve muitos trabalhos realizados através da carreira no Service Autonome des Promenades et Plantations, mas poucos textos sobre urbanismo. Entre seus escritos, destaca-se o livro Grandes Villes et Systèmes de Parcs, publicado em 1908, no qual reuniu sua teoria acerca do tema Sistema de Parques, declarado inovador para época, tornando-se referência para o planejamento urbano.

\footnotetext{
12 "La plupart des municipalités des grandes villes d'Amérique et d'Europe ont aperçu ainsi le danger qu'il y avait à laisser dilapider les espaces encore libres, à laisser défigurer les aspects encore intéressants ou pittoresques de la ville et aussi de ses environs, à laisser fermer par la banlieue toutes les issues vers la campagne. Elles ont compris quels éléments d'hygiène et de beauté une ville en voie de développement peut trouver au cours d'un siècle dans des dégagements, des réserves nombreuses et judicieusement distribuées.

Elles ont compris que le 'plan de ville' est insuffisant s'il n'est complété par un programme d'ensemble et un plan spécial des espaces libres intérieurs et extérieurs pour le présent et l'avenir, - par un système de parcs."

${ }^{13}$ O Musée Social foi um grupo criado em 1894, composto por profissionais de diversas formações que discutiam como melhorar as condições de vida dos trabalhadores na cidade (LECLERC; CID in FORESTIER, 1997).

${ }^{14}$ Instituições como a Section d'hygiéne urbaine et rurale du Mussée social (1908), a Société française des architectes urbanistes (1911), a École d'art public (1916), École des hautes études urbaines (1919), a Ligue urbaine (1928) (LECLERC; CID in FORESTIER, 1997).
} 
O livro foi escrito no momento em que o centro de Paris estava novamente congestionado e os subúrbios (banlieu) transbordavam os limites das antigas fortificações (ville "finie"), clamando por planejamento. Enquanto a sociedade parisiense debatia sobre o destino das terras liberadas pelo desmantelamento das fortificações que cercavam a cidade, Forestier defendia uma política de extensão urbana que integrasse o espaço livre como instrumento de reconquista espacial e territorial.

Forestier afirmava que para atender às necessidades das cidades modernas, o Sistema de Parques deveria evoluir de ferramenta complementar ao plano para se constituir simultaneamente a ele, desta forma, integrando a paisagem ao planejamento urbano de maneira efetiva. Assim, esse pioneiro urbanista francês sistematizou o conhecimento do que entendeu ser um Sistema de Parques, do qual pontuou as seguintes características: em primeiro lugar, se inseria como uma maneira de melhorar a qualidade de vida nas grandes cidades; em segundo lugar, exigia um método e uma diretriz a fim de alcançar o resultado da forma mais econômica, que consistia não somente em calcular a superfície média de espaços livres para uma determinada população, mas em se preocupar com sua melhor distribuição; e, em terceiro lugar, para compreender esse sistema, seria necessário definir os elementos que o formavam. Estes elementos seriam diferenciados por hierarquias de escalas, de conservação e de uso, e distinguidos em: as grandes reservas e as paisagens protegidas, os parques suburbanos, os grandes parques urbanos, os pequenos parques e os jardins de bairro, os terrenos de recreação, que também podiam incluir jardins de infância, e as avenuepromenades.

As grandes reservas e as paisagens protegidas, com área variável e localizadas nas adjacências do perímetro urbano ou um pouco mais distantes, seriam aquelas em seu estado mais natural e que, dependendo das circunstâncias e de sua configuração, podiam ser preservadas. Elas diferiam dos parques propriamente ditos, pois estes demandavam manutenção e teriam tratamento adequado para atender às necessidades da população. Os pequenos parques e os jardins de bairro teriam tratamento paisagístico e abrigariam locais para jogos e exercícios, devendo ser bem distribuídos, de forma que cada família não tivesse que se deslocar mais que 1000 metros para acessá-los. Os terrenos de recreação seriam numerosos, e com áreas separadas para diversão das crianças em diferentes idades. O Sistema 
se completaria com as avenue-promenades ${ }^{15}$, largas avenidas arborizadas, projetadas para deslocamentos e permanências agradáveis que permitiam valorizar os pontos de vista, as margens dos rios e as paisagens interessantes e pitorescas. Elas promoveriam a articulação do sistema e conectariam todos os espaços verdejados e estes às saídas da cidade para o campo.

Assim como Olmsted, o autor de Grandes Villes et Systèmes de Parcs (1908) acreditava no potencial pedagógico que o contato com a natureza poderia proporcionar, apontando a vivência no parque como uma forma de aprendizado com o meio natural, mais eficiente que a sala de aula (FORESTIER, 1997). Forestier reconheceu os esforços das realizações de Haussmann e Alphand na inserção de espaços verdes na organização da cidade, mas diferentemente deles integrou o jardim ao projeto urbano, como ligação ou mediação entre a arquitetura e o território. Em seu percurso desenvolveu as ideias de seus antecessores Alphand e de Olmsted, no sentido de o sistema de parques tornar-se um instrumento de planificação e gestão da terra, envolvendo questões legislativas e econômicas. Forestier avançou sobre as proposições de Olmsted, pois pretendia não apenas a conexão entre os parques como também sua articulação com novos subúrbios (banlieu), abrangendo assim a escala regional.

A respeito do adensamento do centro parisiense e do transbordamento da cidade para além das antigas fortificações, Forestier apontou:

O remédio seria fugir das grandes cidades e voltar ao campo. Talvez venha algum dia, mas hoje a organização social exige esses agrupamentos enormes. Para seus perigos, para seus inconvenientes, é possível fornecer paliativos, se não um remédio, e os municípios podem tentar evitar, em parte, consequências realmente temíveis, mas é necessário fazê-lo metodicamente. (FORESTIER, 1997, p. 51, tradução nossa ${ }^{16}$ ).

Observa-se pelo trecho acima a importância dada por Forestier ao contato com a natureza, sendo possível também vislumbrar sua reflexão acerca das novas propostas de

\footnotetext{
${ }^{15}$ Avenue-promenades eram vias com projeto paisagístico variado, que comportariam o trânsito motorizado, ciclovias e passeio do pedestre (promenade). Apesar da influência higienista, diferiam dos boulevards haussmannianos (definidos por Forestier como as "ruas modernas e largas de Paris, com suas amplas calçadas e arborização regular"), por se constituírem essencialmente em vias de comunicação/ ligação entre os parques e acessos à cidade, podendo ter caráter regional.

16 "Le remède serait de fuir les grandes villes et de retourner à la campagne. Peut-être y viendra-t-on quelque jour, mais aujourd'hui l'organisation sociale exige ces groupements énormes. A leurs dangers, à leurs inconvénients, il est possible d'apporter des palliatifs, sinon un remède, et les municipalités peuvent tenter d'éviter, en partie, des conséquences qui sont vraiment redoutables, encore faut-il le faire avec méthode."
} 
planejamento urbano que surgiriam no final do século XIX. No início de seu livro, o autor analisou os projetos para duas cidades jardim, Adelaide City na Austrália e Garden-City na Inglaterra, nos quais destacou a importância de o plano da cidade contemplar um programa especial para os espaços livres como forma de promover salubridade e controlar a expansão. Contemporâneo às propostas de Forestier, o ideário Cidade Jardim, desenvolvido na Inglaterra por Ebenezer Howard (1850-1928) no livro Tomorrow: A peaceful Path to Social Reform ${ }^{17}$ (1898), reeditado depois com o título de Garden Cities of Tomorrow (1902), foi considerado um paradigma de planejamento urbano pela historiografia. Em seu livro Howard propõe uma alternativa à contraposição vida urbana - vida rural, por meio da criação de uma terceira via em que a urbanização não fosse apenas a contrapartida ao rural, mas um modo de vida urbano aliado ao campo, servindo à população com ambos os benefícios. Para ele, o espaço construído não era algo separado do ambiente natural, sendo papel do plano e do desenho urbano restabelecer a harmonia entre sociedade e natureza. Mais que uma proposta urbanística, sua ideia era também uma proposta social e política para uma sociedade em processo de transformação e de degradação de suas relações (HOWARD, 1996). Portanto, um dos princípios da Cidade Jardim contemplava a questão fundiária, no sentido de gerar oportunidade de acesso à terra e proporcionar uma vida melhor à classe trabalhadora, que estava à margem do processo de especulação imobiliária. Assim, a terra seria controlada por uma associação cooperativa de pequenos proprietários e serviria aos interesses coletivos através de uma "combinação saudável, natural e econômica de vida urbana e rural, e isso em terras de propriedade da municipalidade" (HOWARD, 1996, p. 114).

O campo é a fonte de toda a saúde, de toda a riqueza, de todo o conhecimento. Mas ao homem não foi revelado conhecê-lo na plenitude de sua alegria e sabedoria, e isso nunca poderá ocorrer enquanto perdurar essa infeliz e antinatural separação entre sociedade e natureza. (HOWARD, 1996, p. 110).

O modelo apresentado por Howard (figura 4) consistia em uma cidade central de 58 mil habitantes, conectada por ferrovias e estradas a outras seis Cidades Jardim, limitadas a 32 mil habitantes, que estariam a uma pequena distância da cidade central, minimizando os

\footnotetext{
17 Título da primeira edição do livro, refere-se ao modo como Howard pensava a reforma social através do planejamento do território. Embora fosse militante socialista, Howard divergia de Carl Marx e Friedrich Engels ao propor uma reforma pacífica em oposição a Revolução.
} 
custos e o tempo gasto nos deslocamentos. Howard propôs criar uma nova forma urbana factível através de um padrão que aplicasse os avanços técnicos para acabar com a dependência da metrópole, tornando as pequenas comunidades, antes periféricas, plenamente equipadas de funções sociais e econômicas, exemplo de um sistema autossuficiente (self-maintenance) que se aproxima da ideia contemporânea da sustentabilidade. Ele almejava conter a desordenada expansão das cidades europeias propondo uma nova referência de desenvolvimento urbano, orgânico e descentralizado da grande urbe, por meio da dispersão planificada que resultaria em totalidades unificadas (MUMFORD, 1998).

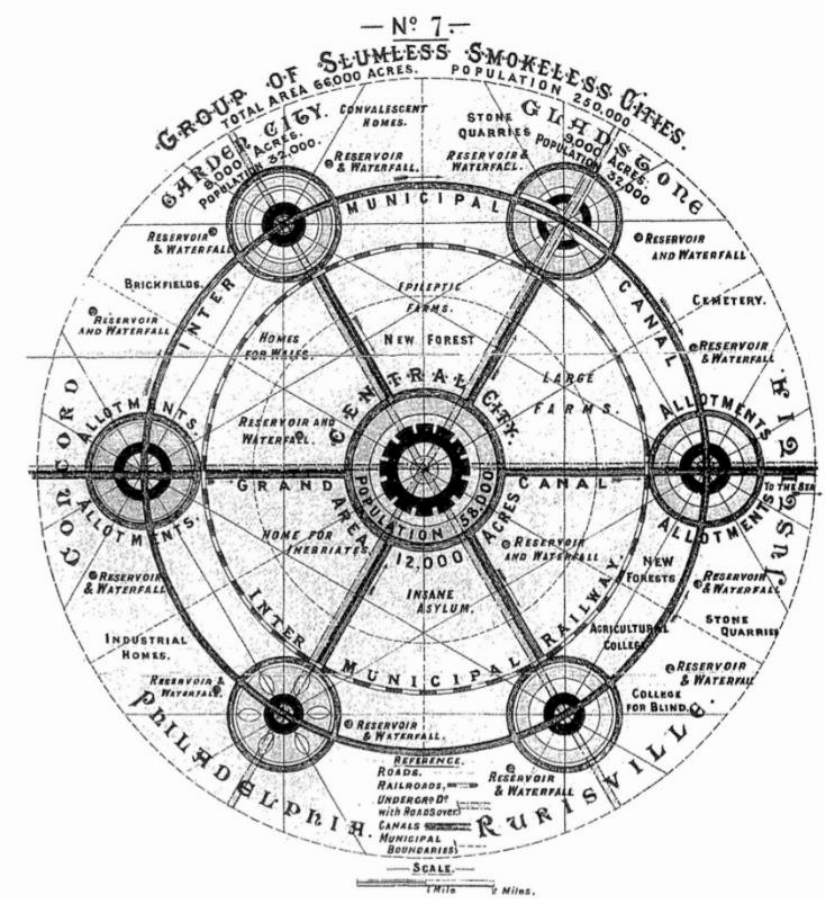

Figura 4: Diagrama no 7 - Agrupamento de Cidades Jardim. Fonte: HOWARD, 1996, p. 204.

Para demonstrar esse novo modelo, ele elaborou uma série de diagramas, tomando devido cuidado para que não fossem confundidos com a representação física de uma cidade, até mesmo porque acreditava que as formas específicas estavam intrinsicamente relacionadas à paisagem, ao relevo, ao clima, à disponibilidade tecnológica e a criatividade dos habitantes de um determinado lugar. O modelo foi representado em seus diagramas (figura 5) por uma gleba que de preferência teria formato circular e cobriria uma superfície de 
2400 hectares, sendo que a cidade propriamente dita ocuparia um sexto da área total; em seu núcleo haveria um espaço verdejado de 2,2 hectares rodeado pelos principais edifícios públicos (sede da municipalidade, hospital, biblioteca, teatros, museus, galerias de arte, salas para concertos) e o Palácio de Cristal, um grande espaço envidraçado para passeios em climas instáveis e que abrigaria um mercado. As habitações, escolas, igrejas estariam dispostas a partir desse núcleo em meio aos espaços verdes ao longo de grandes avenidas concêntricas, semelhantes às avenues-promenades e boulevares radiais. No anel exterior estariam localizadas as fábricas, os armazéns, os mercados, as carvoarias etc. servidas pela linha férrea, que envolveria a cidade e permitiria a comunicação com outras cidades, otimizando o comércio de mercadorias e o rápido transporte intermunicipal de pessoas. Um grande cinturão verde no anel externo limitaria o crescimento urbano e também conservaria próximo o ambiente rural, assim, quando uma cidade atingisse o limite de 32 mil habitantes uma nova cidade jardim seria construída, portanto, garantindo todas as funções essenciais para o desenvolvimento de uma nova comunidade e mantendo a qualidade de vida, principalmente a dos trabalhadores (HOWARD, 1996).
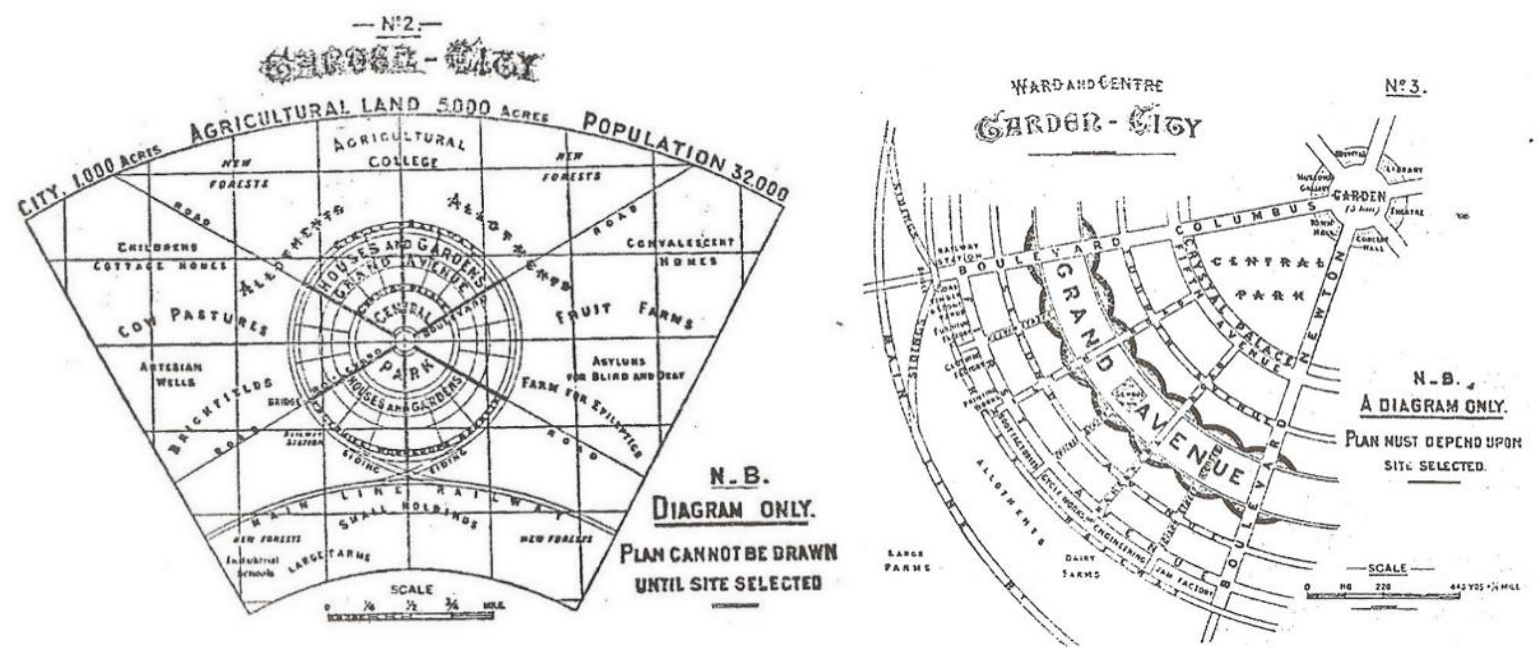

Figura 5: à esquerda, Diagrama no 2 - A Cidade Jardim e seu entorno rural. À direita, Diagrama no 3, detalhe mostrando a distribuição dos espaços verdejados e a organização da Cidade Jardim. Fonte: HOWARD, 1996, p. 113 e 114.

O significativo, com relação à cidade jardim, não era simples presença de jardins e espaços abertos: radicalmente novo era o método racional e ordenado de tratar da complexidade, mediante uma organização capaz de estabelecer o equilíbrio e a autonomia e de manter a ordem, a respeito da diferenciação, e a coerência e unidade, a despeito da necessidade de 
crescimento. Essa é que era a ideia transformadora. (MUMFORD, 1998, p. 560).

Além de expor um paradigma, Howard dedica boa parte de seu livro à explanação de como realizar e manter a cidade jardim. Com base em seu raciocínio foram construídas na Inglaterra as cidades de Letchworth (1902) e de Welwyn (1919), que de acordo com Mumford (1998) revelaram a viabilidade e o êxito das propostas howardianas.

Duas frentes responderam à expansão da cidade industrial. A primeira foi esta que pretendia planejar o território tendo a natureza como a base do planejamento na forma de parques, praças, jardins e ruas arborizadas inseridos na malha urbana, extraindo de cada paisagem suas potencialidades e criando relações variadas com as edificações, de maneira a permitir o contato cotidiano para seus os habitantes. Esses espaços estariam articulados entre si e com o cinturão verde que envolvia a cidade, de forma a promover seu crescimento harmônico.

A segunda frente foi do Urbanismo Racional Funcionalista de matriz Moderna, que no início do século XX buscava na racionalização industrial e nas inovações tecnológicas a porta de entrada para a superação do modelo tradicional de cidade. Durante o IV $\mathrm{CIAM}^{18}$ (Congresso Internacional da Arquitetura Moderna) abordou-se o zoneamento funcional da cidade, fundamentado na separação das diferentes funções - trabalho, moradia, lazer, circulação em uma malha urbana rígida e ortogonal. Esse modelo teria um sistema de vias hierarquizadas de trânsito segregado, com foco no transporte motorizado individual. Em oposição a primeira frente, o Racional Funcionalismo compreendia a natureza como plano de fundo para a arquitetura, reduzida à área verde expressa nos imensos gramados onde eram inseridos os blocos de edifícios-lâminas. Esta era uma proposta replicável que não se atentava às especificidades da paisagem ${ }^{19}$ para ser implantada, o que anos mais tarde gerou críticas por

\footnotetext{
${ }^{18} \mathrm{Em} 1933$ ocorreu em Atenas o IV CIAM, que discutiu "A Cidade Funcional". Todo conhecimento gerado neste congresso deu origem à Carta de Atenas, documento publicado em 1941.

${ }^{19}$ Herzog (2013) apontou que, o modelo de cidade funcionalista trouxe algumas consequências socioambientais negativas, como a erradicação de ecossistemas nativos para construção de extensos gramados e jardins cosméticos; supervalorização do transporte individual; desvalorização da rua como espaço de convivência; e aumentou a especulação imobiliária. Jane Jacobs (2000) no livro "Morte e vida de grandes cidades", fez uma crítica severa ao planejamento urbano Racional Funcionalista Moderno, atacando com veemência a monotonia dos conjuntos habitacionais padronizados, a inutilidade dos extensos gramados, a valorização do automóvel e a insegurança das ruas. Em contrapartida, defendeu que a diversidade de usos nos bairros poderia melhorar a circulação e apropriação das ruas por pessoas, proporcionando segurança e vitalidade a essas ruas. Em relação aos parques urbanos, Jacobs (2000) criticou a excesso de esplanadas, passeios públicos, playgrounds e parques,
} 
parte de urbanistas e estudiosos sobre a cidade. Além disso, esta frente não entendia a expansão ilimitada da cidade como problema.

Contudo, o jardim paisagístico, tributário do pinturesco inglês e grande motivo de desenho dos parques dos finais do século XIX, está excluído dos debates acerca da modernidade, deixando de participar do debate estético e do pensamento arquitetônico. Esse desaparecimento liga-se não só a sua possível associação ao histórico e à tradição, mas também a um processo que passa a perceber esses lugares que anteriormente tinha dimensão e significado na vida das pessoas, como o informe espaço verde. De fato, é toda a questão do jardim em particular e da paisagem de modo geral que são atingidos por esse esvaziamento associado ao fenômeno de supremacia da técnica e consequente crescimento da figura do planejamento. (SCHENK, 2008, p. 26-27).

A circulação desses ideários entre os profissionais atuantes no urbanismo foi impulsionada através de viagens, cursos, conferências e palestras que discutiam propostas para minimizar os problemas da urbe moderna. Com o nascimento do Urbanismo no final do século XIX como campo de conhecimento sistematizado em uma resposta aos males da cidade industrial, parte dos urbanistas captou a importância da natureza e dos espaços livres na manutenção dos sistemas naturais e na melhora da qualidade de vida, retratada em propostas para um desenvolvimento equilibrado econômico e socialmente pautado pela integração à paisagem. O movimento Cidade Jardim foi uma experiência real de construção de cidades mediante à estratégia de inserção da natureza como estruturadora do tecido urbano e teve repercussão internacional na fundação de cidades novas e na reconstrução de cidades europeias no pós Segunda Guerra Mundial, com destaque para o Plano de Patrick Abercrombie para a Grande Londres em 1944.

\subsection{As ressonâncias do modelo Cidade Jardim: Abercrombie e seu Plano para a Grande Londres}

Em 1939, às vésperas da Segunda Guerra Mundial, a Grande Londres abrigava quase nove milhões de habitantes, a maior parte vivendo na área do Condado (BENEVOLO, 2012). Já havia a necessidade de um planejamento urbano frente à expansão demasiada e desorganizada, à alta densidade demográfica e o congestionamento do trânsito na área

impostos pelo governo no intuito de deixar livre grande porção de terreno. A autora afirmou ainda, que as pessoas precisam de motivos para usar um parque e que a vizinhança teria papel fundamental em proporcionar a diversidade física e funcional de usos adjacentes, gerando uma sustentação mútua. 
central de Londres e à ausência de uma política articulada entre os diversos condados que se aglomeravam no entorno da cidade. Em 1941, a destruição causada pelos bombardeamentos, principalmente na área central, tornou premente esse planejamento, além de criar uma oportunidade para organizar logicamente as habitações e as áreas industriais de forma a distribuí-las pela região (ABERCROMBIE, 1945). Assim, antes mesmo do fim da guerra haviam sido encomendados alguns planos para a reconstrução de Londres. Em 1944, o Plano para Grande Londres (Greater London Plan) foi elaborado por Patrick Abercrombie ${ }^{20}$ (1879-1957), arquiteto irlandês que fez carreira como professor e planejador urbano. Foram preparados três planos complementares para a região de Londres: City of London de F. J. Forty, para a reconstrução da área central da metrópole; County of London Plan, de John Henry Forshaw e Abercrombie, que trata da área sob o limite administrativo do condado; e Greater London Plan, de Abercrombie, de escala regional, que envolvia os bairros, distritos e condados.

Abercrombie (1945) investigou em profundidade a região da Grande Londres, detalhando diversas questões relacionadas ao planejamento, abrangendo desde a distribuição populacional e uso e ocupação do território às particularidades de cada comunidade, a conexão entre as diferentes áreas, a provisão de serviços públicos, bem como os aspectos práticos destinados à execução do plano. O Plano chamou atenção para o espraiamento da urbanização para os subúrbios sem o devido planejamento, onde surgiam novos bairros decorrentes da relação de atração entre habitação e indústria, com um desenho urbano de baixa qualidade, resultando em espaços indefinidos para a vida comunitária e, ainda, implicando a ocupação de terras agrícolas férteis. $\mathrm{O}$ arquiteto reconhecia o valor de salvaguardar espaços livres para o lazer e para os benefícios da saúde da população proporcionados pelo contato com a natureza e entendia a importância de reservar áreas agricultáveis no entorno de Londres, onde se podia produzir alimentos para esta população, além de ser esta uma forma de conter o crescimento da cidade, compartilhando assim das convicções de Howard.

\footnotetext{
${ }^{20}$ Leslie Patrick Abercrombie foi professor no Departamento de Projeto Urbano da Universidade de Liverpool entre os anos de 1915 e 1935, depois foi professor de Planejamento Urbano na London College. Em 1910, tornouse editor da primeira revista de planejamento urbano da Inglaterra, a Town Planning Review, também foi membro da Town and Country Planning Association, sendo figura relevante nas discussões sobre planejamento do início do século XX. (LUCCHESE, 2012).
} 
Ao analisar o crescimento da região, Abercrombie constatou que ela já apresentava uma tendência de crescimento em anéis concêntricos e que cada anel apresentava identidade e características intrínsecas e, portanto, essa tendência guiaria o zoneamento proposto no sentido de determinar a densidade populacional, a localização das indústrias e dos espaços livres (open land) para agricultura e recreação. Desta forma, a distribuição dos espaços livres teria papel relevante na estruturação do território, juntamente com a proposta de ordenação em anéis concêntricos e com o sistema de conexão.

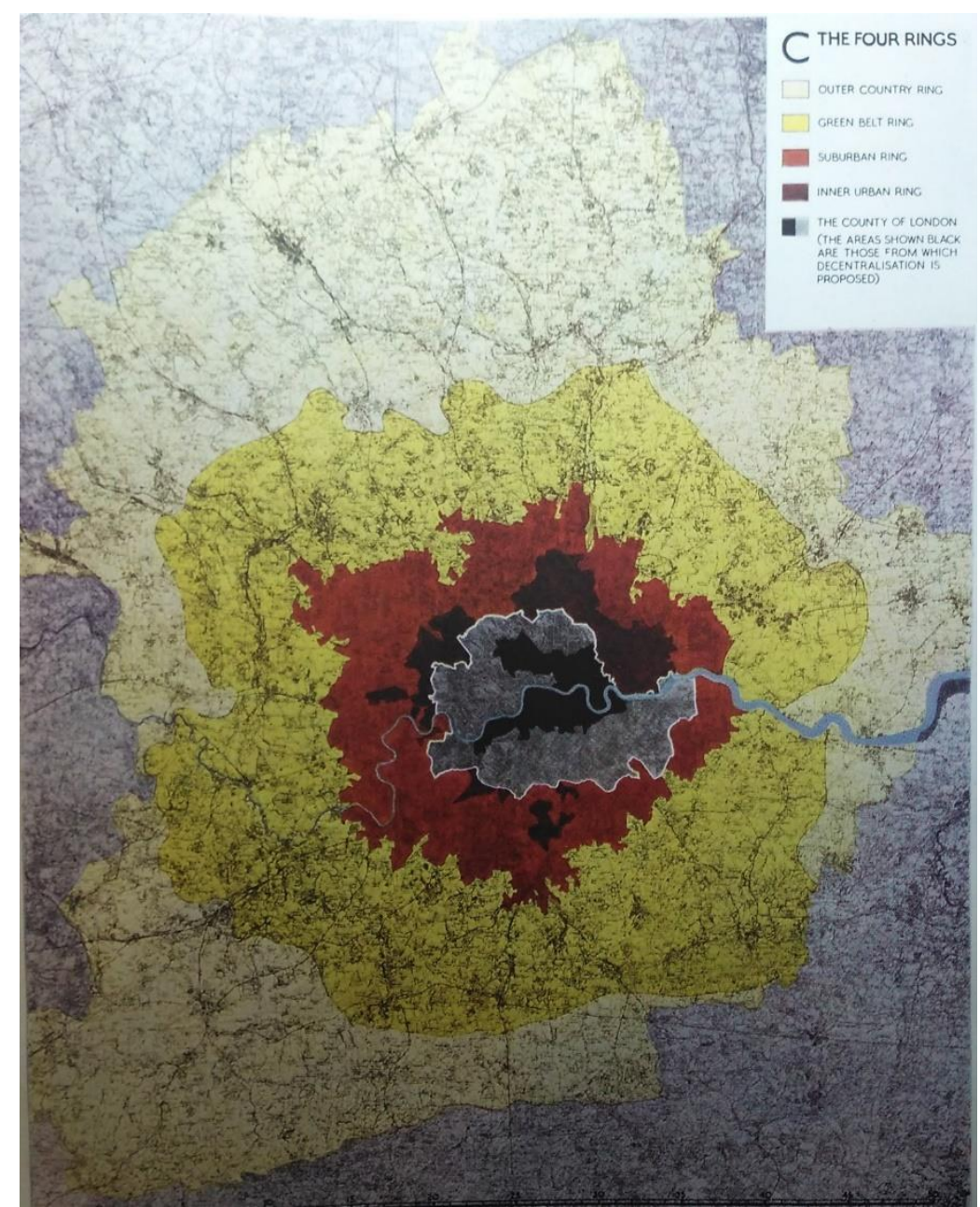

Figura 6: Plano para Grande Londres - Mapa dos Quatro Anéis. Zonas concêntricas com características específicas que formam a região metropolitana da Grande Londres: Anel Interior (partindo da cidade), Anel Suburbano (passando pela área do condado), Cinturão Verde, Anel Externo.

Fonte: ABERCROMBIE, 1945, p. 22.

Foram indicados quatro anéis (figura 6) partindo da área administrativa do Condado de Londres, o Anel Interior (Inner Urban Ring), intensamente destruído pela guerra, e que 
apresentava alta densidade demográfica e escassez de espaços livres, sendo necessária a descentralização da população. Abercrombie (1945) atentou que seria preciso redistribuir indústrias e população, que estavam concentrados na área central e em alguns bolsões na borda regional, com o objetivo estratégico de evitar um arrasamento no caso de bombardeio, bem como de proporcionar melhor qualidade de vida, sendo o acesso às áreas livres um aspecto significativo dessa melhora. Deste modo, sugeriu deslocar alguns habitantes para regiões de menor densidade demográfica dentro da Grande Londres, de maneira articulada às outras proposições do plano. O reagrupamento populacional e industrial considerou ainda a redução do tempo e dinheiro gastos pela população em viagens pendulares, evidenciando a influência dos princípios de Howard a respeito do provimento de uma vida melhor ao trabalhador.

O segundo Anel, o Suburbano (Suburban Ring), explicitava a expansão de Londres, era local de moradia e de indústrias e ainda apresentava alguns espaços livres, que deveriam ser mantidos. Nesse anel a densidade populacional era adequada ao valor estipulado no Plano (exceto nos bolsões de superlotação), assim, não seria permitida a recepção de pessoas descentralizadas (provenientes dos outros anéis).

O terceiro anel, denominado Cinturão Verde (Green Belt Ring), incluía a maior parte da terra que foi adquirida através da Lei do Cinturão Verde (1938) e algumas comunidades que poderiam receber, até um certo limite de expansão, as pessoas vindas dos outros anéis, mas não permitia novas cidades. Este anel seria de extrema importância, pois supriria a necessidade por espaços livres dos anéis anteriores na forma de campos abertos, amplas áreas de parques e bosques para recreação e terras para agricultura. Estas áreas, de propriedade pública ou privada, seriam resguardadas de construção por lei, controlando a expansão urbana.

O último anel, o Externo (Outer Country Ring), de uso predominante agrícola, era pontuado por algumas comunidades. Seus limites foram definidos pelas linhas administrativas, diferentemente dos outros anéis que foram elaborados a partir do uso real. Embora o caráter rural geral devesse ser preservado, esse anel seria o principal local de recepção dos habitantes vindos dos outros anéis, tanto nas comunidades existentes quanto nas novas, as News Towns. A expansão da área urbana no interior do Anel Externo deveria 
observar a variação acentuada da fertilidade da terra e o valor cênico de determinados sítios, relevantes para todos os cidadãos da Grande Londres. (ABERCROMBIE, 1945).

Para resolver o congestionamento na área central e na periferia da área administrativa do Condado, o Plano recomendou um sistema de conexão (figura 7) que seguiria o mesmo padrão de crescimento do zoneamento, ou seja, do centro para as bordas e em anéis concêntricos. O sistema viário teria como base o esquema de vias do Plano do Condado e seria composto por vias arteriais, subdividas em expressas, autoestradas e sub arteriais, que estariam na forma de radiais, anéis e uma cruz central. A proposta desafogaria o trânsito na cidade, além de ter eficiência na conexão com as comunidades periféricas. Para tanto, atentava-se para as intersecções com outras vias, através de um desenho que garantisse segurança e fluidez no trânsito, além de prever a interligação com os outros meios transportes, em escala local, regional e nacional. O sistema viário foi concebido em conjunto com o planejamento agrícola, reflexão necessária para minimizar danos à agricultura e criar estradas com tratamento paisagístico, as parkways. 


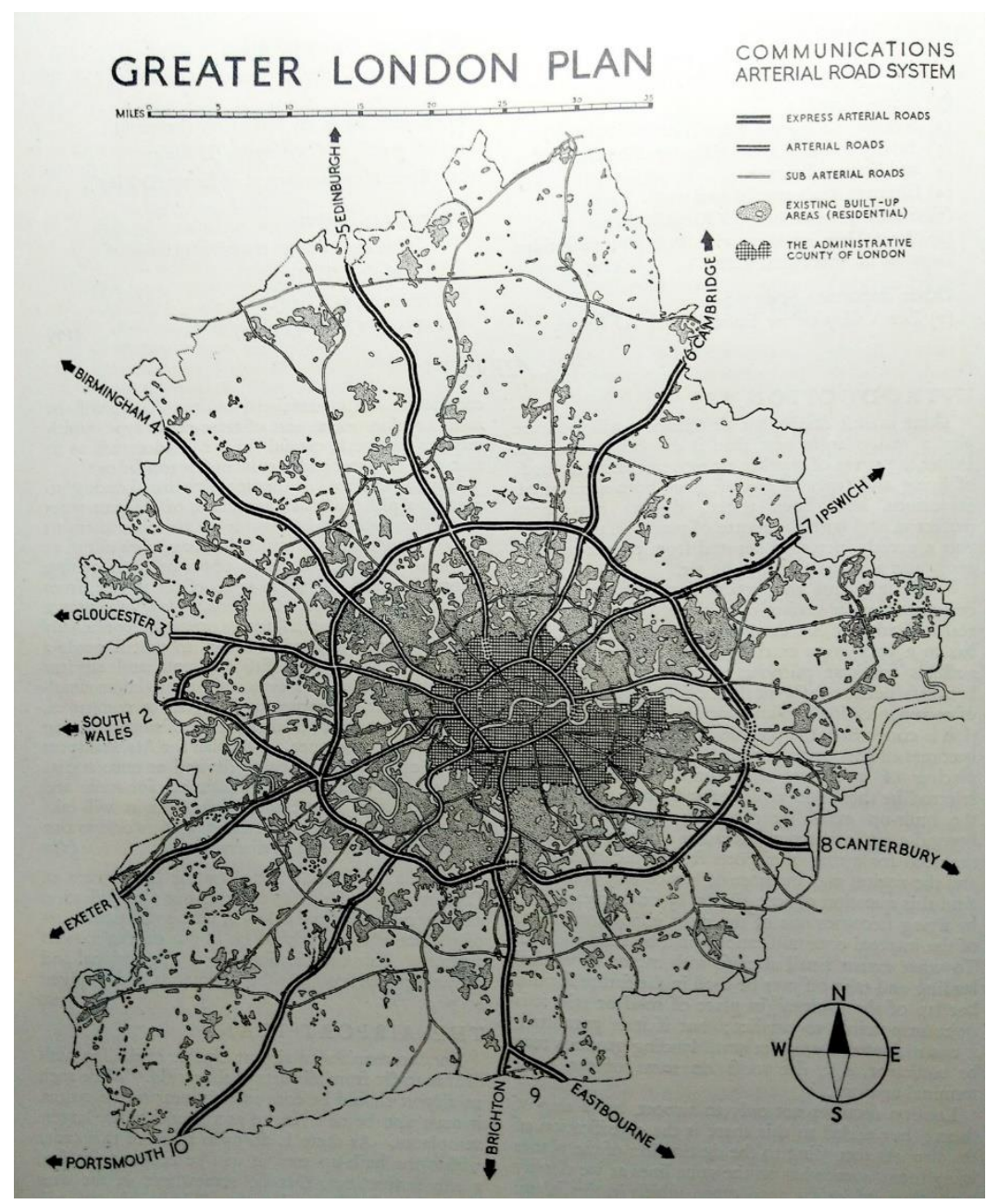

Figura 7: Plano para Grande Londres - Conexões. Mapa do Sistema de Vias Arteriais. Fonte: ABERCROMBIE, 1945, p. 78.

Abercrombie (1945) alertou para a necessidade de se preservar qualquer pedaço de espaço verde existente no interior da malha urbana, para a longo prazo promover a recuperação de tais áreas, como também para se resgatar áreas com características físicas marcantes ou beleza cênica, a exemplo de vales, escarpas, bosques. No Cinturão Verde deveria haver um planejamento dos acréscimos de área, organizados de modo que o uso recreativo interferisse minimamente nas unidades agrícolas. Haveria ainda, três escalas de cinturões verdes: o Metropolitano (Metropolitan Green Belt), envolvendo área urbana central; o local (Local Green Belts), ao redor das comunidades; e as Áreas Cênicas (Scenic Areas), locais de características biofísicas marcantes.

Vale resgatar que a concepção do Cinturão Verde em Londres remonta ao final do século XVI, quando foi proposto através do Act of Parliament com objetivos higienistas e de 
contenção da expansão urbana. Posteriormente, durante o século XIX, a ideia foi retomada pela Town and Country Planning Association (TCPA), associação responsável pela divulgação dos ideais de Cidade Jardim na Inglaterra (LUCCHESE, 2012). Em 1938 o Cinturão Verde tornou-se lei, por meio da qual as autoridades locais estavam habilitadas a comprar terras para incorporá-las ao cinturão, a princípio visando atividades recreativas, mas também na intenção de resguardá-las para o uso agrícola. Abercrombie (1945) reconheceu os benefícios proporcionados por estes espaços em termos visuais e de saúde, bem como o retorno financeiro deste investimento. Foi com o Plano para Grande Londres que o cinturão realmente ganhou forma.

Observa-se esta relevância no capítulo dedicado inteiramente ao tema "Recreação ao ar livre: espaços livres" (Outdoor Recreation: Opens Spaces), no qual indicou a complexidade ao se tratar de tais espaços no planejamento e sugeriu a abordagem de forma sistêmica. Além desse, outro capítulo foi dedicado à análise da classificação das terras e da agricultura.

Em nenhum aspecto da região de Londres há uma interação mais próxima entre o centro construído e a margem mais externa da periferia do que na recreação ao ar livre. Ela varia desde o menor espaço infantil da cidade ou praça da cidade ao que pode parecer um fragmento da Inglaterra rural que segue sua vida agrícola distante de qualquer influência urbana. $O$ assunto é tão vasto, suas ramificações tão numerosas, que nenhuma seção de um relatório como esse poderia esperar lidar adequadamente com ele. De fato, toda uma literatura surgiu, em grande parte preocupada com a história da preservação dos bens inestimáveis de Londres em espaços livres. No máximo, podemos apenas tocar em algumas características salientes e na necessidade de um estudo sistemático que corrija a distribuição irregular e solde as partes separadas em um todo. Como já foi afirmado repetidamente, a necessidade de ação unificada passou a constituir uma ação efetiva em conjunto para o planejamento regional sob a Lei do Cinturão Verde. (ABERCROMBIE, 1945, p. 97, tradução nossa ${ }^{21}$ ).

\footnotetext{
${ }^{21}$ "In no aspect of London's region is there closer interaction between the built-up centre and the outermost verge of the periphery than in that of outdoor recreation. It ranges from the smallest children's play-space or city square to what may appear to be a fragment of rural England pursuing its farming life remote from any urban influence. The subject is so vast, its ramifications so numerous, that no section of a report such as this could hope to deal adequately with it. Indeed a whole literature has come into being, largely concerned with the history of the preservation of London's priceless possessions in open spaces. At most we can only touch on certain salient features and the need for a systematic study which will correct irregular disposition and weld separate parts into a whole. As has repeatedly been stated, the need for unified action brought into being an effective piece of joint action for regional planning under the Green Belt Act. And yet the Green Belt Act only touched one or two aspects of the park system."
} 
Em seguida Abercrombie enumerou alguns fatores relacionados com a oferta de espaços na intenção de criar o sistema. O primeiro fator analisado foi a da área cultivada (acreage) em relação à população, assunto que julgou ser bastante complexo para simplesmente indicar um índice, pois este não consideraria a diversidades de espaços existentes, a propriedade, a tipologia, os usos, a distância percorrida até eles e os usuários. O segundo fator referia-se ao aproveitamento das oportunidades da topografia natural, que seria de grande interesse para o sistema ao mesmo tempo em que limitavam a ocupação humana. O terceiro fator colocou o campo como significativo elemento atrativo da população urbana e, na impossibilidade de fácil acesso a ele, os parques urbanos seriam uma opção. Portanto, o planejamento destes espaços deveria cogitar os variados tipos de passeios tais como, em grupo, aos finais de semana, em um único dia, a pé, de carro ou ônibus etc., assim como a distribuição entre os diferentes usos: jogos, caminhadas, contemplação, recreação, que seriam o quarto fator analisado. Por último, deveriam ponderar a existência de graus entre uso público e uso privado e a incerteza relacionada à inserção dos espaços privados no sistema, pois poderiam desaparecer devido ao custo financeiro referente à manutenção destes locais e às obrigações incidentes sobre os proprietários. Lembrando que as áreas de beleza cênica, mesmo com uso parcialmente público, participariam do sistema, ainda que apenas visualmente (ABERCROMBIE, 1945).

O mapa a seguir (figura 8) mostra o Sistema de Espaços Livres em contraste com a área construída, tanto existente quanto proposta, em marrom-avermelhado. Em verde escuro estão representados os espaços livres existentes salvaguardados de construção e com acesso público limitado e tamanho variável, incluindo desde florestas até pequenas áreas de recreação. E em verde claro, estão as áreas para as quais se propunha o acesso público total. Já em amarelo-esverdeado escuro figuram as terras onde era proibido construir e às quais não há acesso público, a saber, áreas de instituições, hospitais, campos particulares, terrenos adquiridos de acordo com a Lei dos Cinturões Verdes. Em amarelo claro, estão as terras restantes, também protegidas de construção, enquanto a tonalidade escura representa o Cinturão Verde, anel com aproximadamente 5 milhas de comprimento que contorna as áreas urbana e suburbana consolidadas. Nesta região, o valor da recreação seria maior que o da agricultura, relação que se inverte no anel rural (Anel Externo); o acesso público de passagem 
por meio de trilhas seria legal, havendo áreas particulares de uso restrito. O mapa mostra ainda regiões de valor cênico de especial importância regional ou nacional que estariam protegidas de transformações que mudassem o caráter da paisagem.

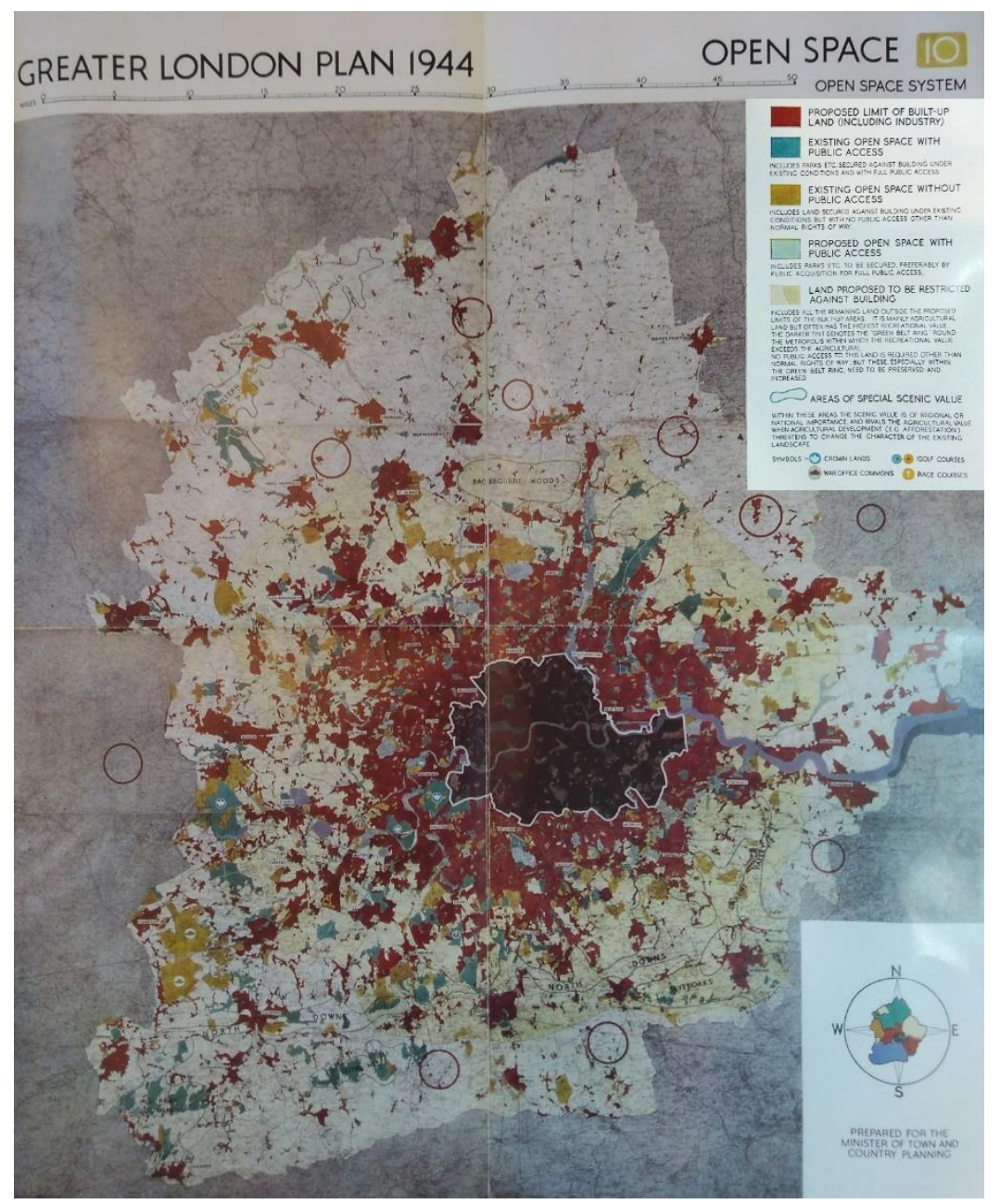

Figura 8: Plano para Grande Londres - Mapa do Sistema de Espaços Livres. Fonte: ABERCROMBIE, 1945, p. 110 (modificado pela autora).

Abercrombie (1945) salientou a mudança do paradigma do planejamento ao declarar que todo terreno não construído e não demarcado para tal fim fosse considerado espaço livre, enfatizou também a necessidade contínua de aquisição de novas terras públicas para manutenção do Sistema de Espaços Livres. Todos os espaços livres da Grande Londres deveriam estar sob os cuidados de um Conselho Regional, que seria responsável também pela aquisição de terras no futuro.

Um aspecto do Mapa das propostas de espaço livre que não pode ser enfatizado demais é o fato de que toda a terra de fundo, fora daquelas áreas 
que já foram construídas ou propostas para serem construídas, nenhum novo edifício deve ser erigido. Essa concepção, que é revolucionária na prática, reverte o atual estado de coisas em que os edifícios podem ser erguidos em quase qualquer lugar. Esta proposta implica, portanto, a execução radical de uma política nacional alterada, com linhas pelo menos tão fortes quanto as do Relatório da Comissão Uthwatt. Ele produz uma imagem de edifícios em um mar de verde, em vez de construir em qualquer lugar com resgates efetuados para o espaço livre aqui e ali. Portanto, diminui a necessidade de aquisição por atacado de áreas livres públicas, e as propostas de espaço livres são mostradas com parcimônia no Mapa [figura 8] fora da comunidade construída. No entanto, não eliminará inteiramente a necessidade da transferência de propriedade para o público. Áreas recreativas, pontos de interesse cênico, grandes parques e outras áreas que devem ser disponibilizadas para acesso ilimitado ainda devem ser adquiridos. As compras propostas no Cinturão Verde (em oposição àquelas já organizadas) não foram mostradas no Mapa. Algumas delas ainda serão concluídas e muitas outras adicionadas, mas a ênfase será na recreação, e não na compra de terras agrícolas. (ABERCROMBIE, 1945, p. 100-101, tradução nossa' ${ }^{22}$.

O Sistema de Parques proposto visava atender os diferentes tipos de usos, a quantidade ideal de espaços livres e ainda os distribuir onde fossem desejáveis. Para tanto, assim como Forestier, Abercrombie sugeriu os seguintes componentes do sistema (ABERCROMBIE, 1945):

1. Parques infantis: para crianças até 10 anos de idade.

2. Praça da cidade, jardins de descanso: localizados na área urbana consolidada.

3. Playgrounds e espaços livres escolares: poderiam estar combinados com os parques urbanos.

4. Parques urbanos.

\footnotetext{
22"One aspect of the open space proposals Map which cannot be over-emphasised is the fact that all the background land, outside those areas which have been already built up or proposed to be built up, no new buildings are to be erected. This conception, which is revolutionary in practice, reverses the present state of affairs in which buildings can be erected almost anywhere. This proposal therefore implies the radical carrying out of a changed national policy on lines at least as strong as those in the Uthwatt Committee's Report. It produces a picture of buildings in a sea of green, rather than building anywhere with rescues effected for open space here and there. It therefore lessens the need for wholesale acquisition by the public of open areas, and proposals for open space on the Map outside the built-up communities. It will not, however, entirely do away with the need for the transference of ownership to the public. Recreational areas, points of scenic interest, great parks and other areas which should be made available for unlimited access should still be acquired. Proposed purchases in the Green Belt (as opposed to those already arranged) have not been shown on the Map. Some of these will still be completed and many others added, but the emphasis will be on recreation rather than on the purchase of farmlands."
} 
5. Grandes campos de jogos para adultos e crianças em idade escolar: preferencialmente na escala local.

6. Centros de recreação e esportes: grandes áreas destinadas aos jogos ou contemplação da paisagem, oferecidos de acordo com as necessidades da comunidade.

7. Parques lineares/ Parkways radiais e conectoras: seriam os elos de ligação do sistema, como faixas alongadas de espaço livre de largura variável relacionadas aos cinturões menores; caminhos ribeirinhos; trilhas (footpaths), que geralmente consistiam em direito de passagem sobre terras agrícolas; estradas rurais; ciclovias; estradas com tratamento paisagístico e com tráfego destinado ao deleite do caminho e com locais adequados à parada; estradas arteriais expressas de trafego motorizado, que não seriam consideradas parte do Sistema de Parques, mas dariam acesso aos espaços livres.

8. Espaços abertos interpenetrados, ou seja, que podem se sobrepor a outros espaços, conectando-os para formar o sistema.

9. Cinturões verdes pequenos e outros espaços abertos para definir os limites e a expansão das comunidades.

10. Áreas comuns e áreas de várzea: as várzeas e outras terras baixas seriam regiões sujeitas a inundações e não seriam adequadas para a construção.

11. Espaços ao redor do rio Tâmisa e outros rios: o Tâmisa era considerado de grande valor recreacional para os londrinos, pois fornecia variados tipos de atividades para diferentes grupos da população. Abercrombie (1945, p. 105) salientou os benefícios propiciados pelos cursos d'água e seus vales como "mais desejáveis quebras para a monotonia e a regularidade do planejamento urbano e suburbano". Portanto o objetivo seria aumentar as áreas abertas ao uso público, recuperar áreas industriais degradas e integrá-las ao sistema.

12. Cinturão Verde Metropolitano, florestas, colinas, parques campestres.

13. Áreas de grande valor cênico: áreas com características notáveis, por exemplo, algumas colinas, picos, escarpas, encostas, florestas, várzeas. Era desejável que 
essas terras mudassem para a posse pública absoluta para terem proteção mais eficiente.

14. Área rural: compreendia terrenos que sofriam influência urbana direta, conhecidos como terras do cinturão verde (green belt farmland), campo agrícola normal e terras distantes dos efeitos urbanos. Seriam acessíveis para recreação somente por trilhas, caminhos verdes e estradas rurais a partir das áreas urbanas e pelas faixas de espaço livre.

Abercrombie (1945) compreendeu os obstáculos para a implantação de um sistema perfeitamente articulado numa área urbana consolidada como Londres, mas considerou a importância da interligação entre estes espaços através de vias radiais, diagonais e anelares, que deveriam ser facilmente acessadas mediante locomoção em agradáveis condições. O Plano apresentava ainda um mapa de trilhas (footpath) (figura 9) que percorriam todo o território estudado conectando os espaços entre si e com albergues da juventude. Deste modo, o Sistema de Espaços Livres seria interligado por essas trilhas, por parques lineares e caminhos verdes para a locomoção de pedestres, constituindo uma conexão tão eficiente quanto a motorizada. 


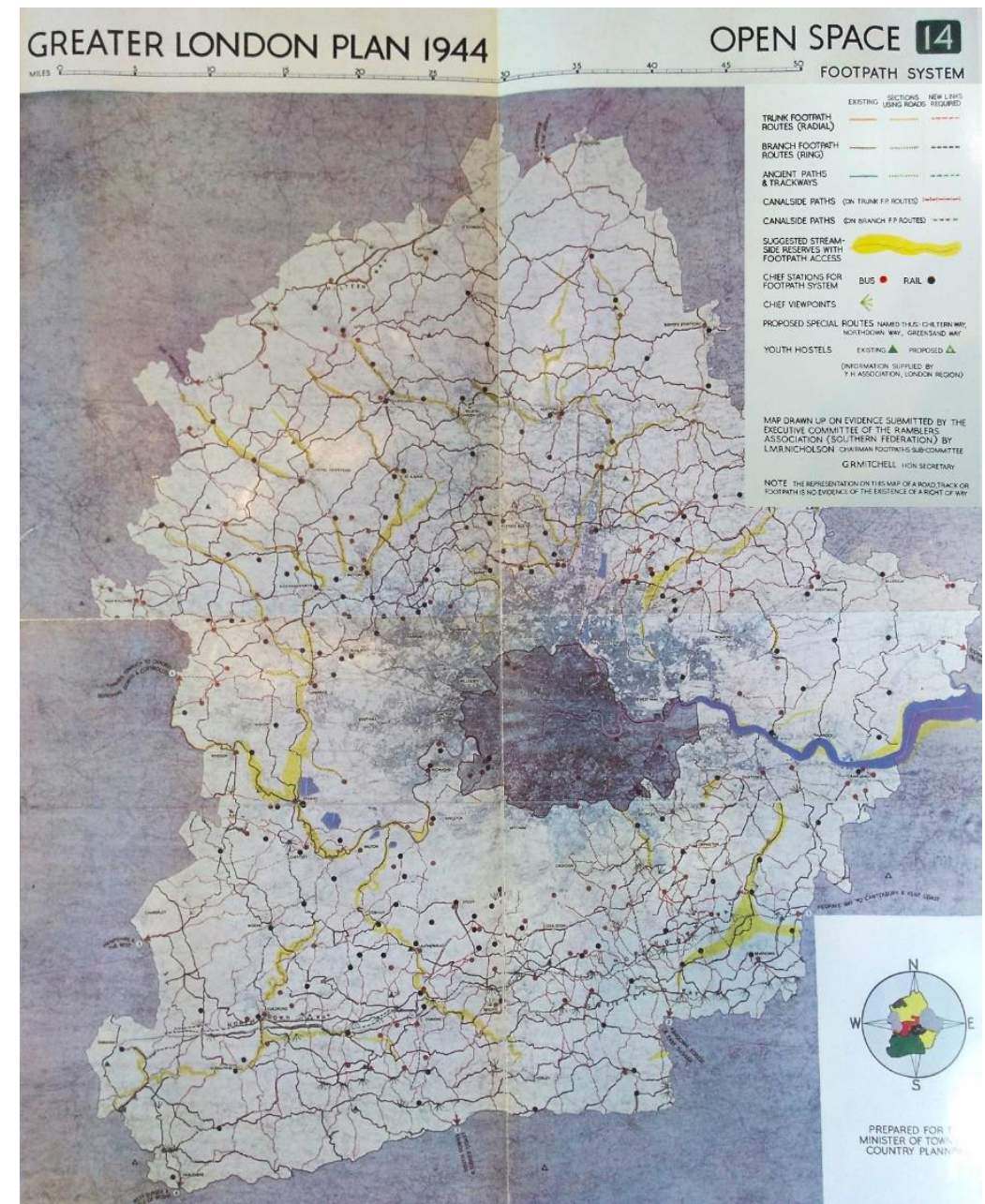

Figura 9: Plano para Grande Londres - Mapa do Sistema de Trilhas. Fonte: ABERCROMBIE, 1945, p. 110 (modificado pela autora).

Através do Plano para a Grande Londres, Abercrombie conseguiu convergir todas as experiências londrinas anteriores na direção de implantar um cinturão verde articulado ao Sistema de Espaços Livres. Ele explicitava a importância de salvaguardar terras tanto para usos contemporâneos quanto para benefícios futuros e indicar o uso mais adequado de acordo com suas características. É evidente a influência dos princípios howardianos no que se refere aos espaços verdejados permeando e estruturando malha urbana, assim como a utilização do cinturão verde na intenção de limitar o crescimento urbano. Abercrombie também se aproximou do Sistema de Parques elaborado por Forestier ao propor a categorização dos espaços livres como meio de organizá-los e de direcionar a expansão da metrópole. 


\subsection{Planejamento Ecológico e a Paisagem}

Ainda no período pós Segunda Guerra, as demonstrações das aplicações negativas da ciência na Guerra deixaram a sociedade estarrecida, enquanto no meio acadêmico a inquietação com o momento era de compreensão e aprofundamento do conhecimento tecnológico e científico direcionado para a reconstrução urbana e expansão industrial. No campo da Arquitetura da Paisagem desenvolvia-se o interesse pelas ciências naturais, sistemas e métodos racionais na direção de uma abordagem ecológica, que também começavam a tomar forma (WALKER; SIMO, 1994).

Na década de 1950, Hideo Sasaki ${ }^{23}$ (1919-2000), arquiteto da paisagem estadunidense e professor no Departamento de Arquitetura da Paisagem de Harvard, revolucionou o estudo de arquitetura paisagística ao promover a interdisciplinaridade no processo de planejamento urbano e projeto da paisagem. Suas aulas contavam com a participação de docentes de outros campos disciplinares e de colegas de profissão, o que se refletiu em um método de ensino com ênfase na elaboração de projetos em grupo e na aproximação com a prática profissional. Ele entendia que o projeto deveria refletir seu contexto cultural, histórico, geográfico, ambiental, social e econômico, instituindo uma abordagem ampla e o estímulo de habilidades artísticas, intelectuais, técnicas.

Numa das primeiras aplicações desta abordagem, Sasaki e outros membros do corpo docente organizaram uma oficina em que os alunos investigaram um local acerca das condições do solo, dos padrões de escoamento de água, dos tipos de vegetação, entre outros fatores, o que resultou no encaminhamento de áreas para o desenvolvimento urbano e outras para a preservação ambiental. De acordo com o arquiteto, a experiência seria inovadora por envolver uma ponderação, pois racionalizava "[...] onde [o desenvolvimento] deveria estar,

\footnotetext{
${ }^{23}$ Hideo Sasaki formou-se arquiteto da paisagem em 1946 pela Universidade de Illinois, depois se pós-graduou em 1948 na Universidade Harvard, na qual também foi professor (1953-1970) e diretor (1958-1968) no departamento de arquitetura paisagística (Harvard Graduate School of Design). Foi considerado de vanguarda por transcender métodos tradicionais de ensino e de prática profissional ao estimular a interdisciplinaridade no processo de planejamento e projeto da paisagem. Fundador da Sasaki, Walker and Associates, empresa focada em projetos que promoviam a integração do terreno com os edifícios e com ambiente circundante. Fonte: Homepage da The Cultural Landscape Foundation, disponível em: <https://tclf.org/pioneer/hideo-sasaki>. Acesso em: 02 set. 2019.
} 
não o que e quanto, mas onde." (SASAKI citado por WALKER; SIMO, 1994, p. 263, tradução nossa $\left.{ }^{24}\right)$.

A preocupação com o ambiente seguiu crescente durante a década de 1960 e outros métodos de análise da paisagem para aplicação no planejamento do uso da terra foram testados, então com a adição de valores ecológicos e sociais. Walker e Simo (1994) citaram alguns trabalhos nessa nova perspectiva, como o do pesquisador canadense G. Angus Hills, que inicialmente desenvolveu métodos de classificação e avaliação de terras para silvicultura e agricultura, com subsequente utilização na ecologia e na destinação de terras para recreação. Em 1966, ele promoveu a classificação de sítios de acordo com sua "capacidade (ou potencial 'verdadeiro'), sua adequação (ou potencial imediato) e sua viabilidade (ou provável potencial)" (WALKER; SIMO, 1994, p. 264). Posteriormente, Hills iniciou uma análise sobre unidades naturais de sítios chegando à subdivisão em unidades fisiográficas, contribuindo para o estabelecimento de uma base científica e sistemática na avaliação se sítios.

Outro estudo de referência foi o do norte-americano Philip Lewis, professor de Arquitetura da Paisagem, conhecido por criar o termo "corredor ambiental" (environmental corridor) (1961), com aplicação no mapeamento de regiões para orientar o planejamento. Lewis utilizava o método de sobreposição de mapas como parte do processo de projeto e, além disso, desenvolveu um sistema numérico de classificação de qualidades e características da paisagem, que envolvia dados como qualidade visual e bem-estar físico, avançando ao possibilitar o acesso aos dados através do computador. Walker e Simo (1994) ressaltaram a aproximação dos habitantes das áreas em estudo a partir das pesquisas de Lewis e Hills, não apenas no processo de coleta de dados, mas ao incluir nas análises os valores compartilhados por estas pessoas.

Desta forma, são significativos nesse período, especialmente nas universidades, o reconhecimento de métodos utilizados nos primeiros ensaios de um sistema de mapeamento coordenado com a sobreposição de foto aérea sobre mapa topográfico, assim como o uso do computador como ferramenta nos estudos de planejamento regional. Foi na década de 1960 que a historiografia consagrada da Arquitetura da Paisagem desenvolveu com mais ênfase o

\footnotetext{
24"But for the first time, we rationalized where [development] should be, not what and how much but where."
} 
tema da Paisagem em diálogo com o planejamento, destacando o vínculo com a ecologia e com a conservação dos recursos naturais. Nesse percurso, apresentaram-se alguns estudos relevantes que consolidaram as bases do Planejamento Ecológico da Paisagem, campo no qual destacou-se o trabalho do arquiteto da paisagem lan McHarg.

\section{Planejamento ecológico e a paisagem: o legado de lan McHarg}

Em meados da década de 1960, o movimento ambiental começou a se fortalecer, ao mesmo tempo em que novas ferramentas para análise da paisagem eram testadas nas universidades norte-americanas. Nesse contexto, foi importante a atuação do arquiteto da paisagem escocês lan McHarg (1920-2001), conhecido ${ }^{25}$ por sua contribuição para o Planejamento Ecológico. McHarg estudou artes plásticas na Faculdade de Arte de Glasgow e, nos Estados Unidos, obteve o mestrado em Arquitetura da Paisagem e Planejamento Urbano na Universidade de Harvard, posteriormente tornando-se professor na Universidade de Pensilvânia, onde fundou o Departamento de Arquitetura da Paisagem em 1956.

O interesse inicial de McHarg como arquiteto era proporcionar às pessoas uma cidade agradável para se viver. Depois, na década de 1960, em reposta à expansão demasiada dos assentamentos humanos e a consequente degradação ambiental, sua inquietação passou a ser a sobrevivência do planeta (WALKER; SIMO, 1994). Ele criticaria o ser humano moderno, que apresentava esse tipo de desenvolvimento como um modelo único, baseado fundamentalmente em questões econômicas, no êxito do produto nacional bruto e cuja grande medida é monetária. "É irônico que esse grande investimento público nas cidades também seja aquele que financiou sua própria destruição" (MCHARG, 2000, p. 21, tradução nossa $\left.{ }^{26}\right)$.

\footnotetext{
${ }^{25}$ Entre os anos de 1960 e 1961, McHarg apresentou o programa de televisão "The House We Live In" (A Casa em que Vivemos) na CBS, em que discutia com seus convidados, entre eles cientistas, líderes religiosos e intelectuais, a desconstrução da noção antropocêntrica de desenvolvimento e suas consequências para o ambiente natural (WALKER; SIMO, 1994). Ele também atuou no escritório Wallace-McHarg Associates, fundado em 1962 com o arquiteto David Wallace, empresa que se expandiu incorporando William Roberts e Thomas Todd, ficando conhecida como WMRT. Através dessa empresa McHarg pôde aplicar todo seu conhecimento de planejamento ecológico em projetos como The Woodlands, The Potomac River Basin Study, Plan for the Valleys. Fonte: Homepage The Cultural Landscape Foundation, disponível em: <https://tclf.org/pioneer/ian-mcharg>. Acesso em: 04 set. 2019.

26 "Resulta irónico que esta gran inversión pública em las ciudades sea tabiém la que há financiado su propia destrucción."
} 
Seus ideais foram publicados no Design with Nature (1969) ${ }^{27}$, livro em que detalhou o Planejamento Ecológico e enfrentou o desafio do desenvolvimento humano em congruência com a natureza. Lewis Mumford, que escreveu a introdução para a primeira edição do livro, comentou a aparição tardia dos esforços para se construir um ambiente renovável e equilibrado, esforços que denominou como ecológicos. Mumford destacou que o livro trouxe uma contribuição sem igual, pois McHarg foi capaz de juntar sua experiência como planejador urbano e arquiteto da paisagem com o domínio do campo ecologia para além da teoria, numa combinação de "profundidade científica e de desenho ambiental" aplicados em projetos construídos. Mumford (in MCHARG, 2000) ressaltou ainda que McHarg não se limitou a enumerar as mazelas provocadas pelo ser humano ao ambiente natural, mas se utilizou de todas essas informações para apresentar um modelo de planejamento para o contexto real e atrelado à melhoria da qualidade de vida.

Ao estabelecer a necessidade de uma intervenção consciente, de uma avaliação ética, de uma organização metódica e abordagens estéticas deliberadas que levem em consideração todos e cada um dos espaços do entorno, McHarg não coloca a ênfase unicamente no projeto ou na natureza separadamente, mas sim na preposição com, o que implica cooperação entre o homem e os elementos biológicos. Não se pretende impor o desenho de um modo arbitrário, sim utilizar ao máximo o potencial que a natureza nos oferece sem esquecer as necessárias restrições que ela impõe. Deste modo, ao incorporar a natureza em sua totalidade, sabe que o espírito do homem como uma parte dela que é, possui algo muito valioso para adicionar a esse potencial; algo que é impossível encontrar no nível mais alto da evolução da natureza virgem, sem intervenção pelo homem. (MUMFORD in MCHARG, 2000, p. XVII, tradução nossa ${ }^{28}$ )

McHarg não negava o progresso da humanidade, mas desaprovava o modo de desenvolvimento com base naquilo que denominava antropocentrismo, que reconhecia a natureza como algo externo ao homem, um bem a ser conquistado e espoliado. Não se tratava

\footnotetext{
${ }^{27}$ A primeira edição do livro foi lançada em inglês em 1969, com o título 'Design with Nature', mas para esta dissertação consultou-se a versão em espanhol 'Proyectar con la naturaleza' publicada em 2000.

28 "Al establecer la necesidad de una intervención consciente, de una valoración ética, de una organización ordenada y de unos planteamientos estéticos deliberados que tengan en considera-ción todos y cada uno de los aspectos del entorno, McHarg no coloca el énfasis únicamente en el proyecto o en la naturaleza por separado, sino en la preposición con, por lo que implica de cooperación entre el hombre y los elementos biológicos. No pretende imponer el diseño de un modo arbitrario, sino utilizar al máximo el potencial que la naturaleza nos ofrece, sin olvidar las necesarias restricciones que impone. De este modo, al incorporar la naturaleza en su totalidad, sabe que el espíritu del hombre, como parte de ella que es, posee algo muy valioso para añadirlo a ese potencial; algo que es imposible encontrar en el nivel más alto de evolución de la naturaleza virgen, no intervenida por el hombre."
} 
de escolher um lado, mas de concebê-los como unidade. Tal separação teria ocorrido pela falta de visibilidade e entendimento dos processos naturais que sustentam vida. Em seus escritos ele condenou o modo da sociedade apresentar a natureza em apenas dois registros: como objeto decorativo e como objeto de exploração. Estava claro que a natureza proporcionava deleite e beleza, um conforto em meio ao ritmo frenético da cidade, porém, mais do que isso, seus benefícios deveriam ser compreendidos como a fonte de vida e, portanto, era necessário respeitá-la. Uma boa maneira para assimilar os fenômenos naturais seria através da ecologia, pois ela é a ciência que estuda a "interação entre os organismos e seu entorno", como bem resumiu McHarg (2000, p. 29). A contribuição fundamental do autor foi unir desenvolvimento científico e percepção, como um participante consciente dos processos naturais e dos valores representados por eles.

Em seu livro Design with Nature (1969), McHarg demonstrou serem possíveis intervenções que estivessem em harmonia com a natureza, afirmando que os arquitetos da paisagem administrariam bem esse desafio, ou seja, um planejamento atento às dimensões ambientais, culturais, sociais e econômicas. Nesse sentido, um determinado local seria constituído por estas dimensões inerentes à Paisagem que seriam relevantes para a sobrevivência humana por estarem conectados a elas.

O argumento inicial utilizado foi que esta zona é a soma de uma série de processos históricos, físicos e biológicos, todos eles dinâmicos, que constituem valores de interesse social. Cada zona tem uma idoneidade intrínseca para certo o uso do solo e certas zonas prestam a múltiplos usos coexistentes. (MCHARG, 2000, p. 104, tradução nossa ${ }^{29}$ ).

Os processos naturais relacionados à água, o solo, o ar, a fauna e a flora eram considerados indispensáveis à sobrevivência humana e, portanto, foram denominados valores sociais. Os processos históricos, de igual maneira, eram de grande interesse social. Desta forma, estes elementos seriam avaliados para determinar oportunidades e limitações intrínsecas a cada região. McHarg (2000) destacou que os valores sociais, representados pelos processos naturais, geralmente permitiriam uma multiplicidade de usos humanos, sendo citados os exemplos do terreno bem drenado, que permitiria tanto o uso recreativo quanto o

29 "El argumento de partida que se utilizó fue que esta zona es la suma de una serie de procesos históricos, físicosy biológicos, todos ellos dinámicos, que constituyen valores de interés social. Cada zona tiene una idoneidad intrínseca para ciertos usos del solo y ciertas zonas se prestan a múltiples usos coexistentes." 
uso comercial e industrial; dos locais de elevado interesse paisagístico, que seriam adequados para o uso residencial e recreativo passivo. Este aparente conflito seria resolvido pela coexistência dos usos, desde que os valores sociais fossem assegurados, ou ainda, pela escolha da população. Em outra situação, em que a houvesse escassez ou vulnerabilidade de certo recurso natural, se aumentaria consideravelmente seu valor para a conservação, impossibilitando outro uso. O autor ressalta a importância de reconhecer a dinamicidade desses processos e a sua interação com as ações provocadas pelo homem que, por sua vez, seria afetado por essas intervenções.

A complexidade do método, que poderia resultar nesta indicação de usos múltiplos ou complementares em uma mesma área, foi considerada uma inovação por McHarg, pois poderia ser desejável pela população, mesmo havendo divergência com o princípio do zoneamento, largamente aplicado no planejamento.

Normalmente, mapas de uso da terra e propostas de gestão da terra mostram amplas categorias de uso. Os mapas do presente estudo são mais parecidos com mosaicos do que com pôsteres, pois são o resultado de pedir à terra que manifeste propriedades discretas que, quando sobrepostas, revelam uma grande complexidade. Mas essa é a verdadeira complexidade de oportunidade e limitação. A aparência anárquica se deve ao fato de nos acostumarmos à exigência monótona do zoneamento, porque não estamos acostumados a perceber a verdadeira diversidade do ambiente natural ou a responder, com nossos planos, a essa diversidade. (MCHARG, 2000, p. 115, tradução nossa ${ }^{30}$ ).

McHarg reprovava o modelo de planejamento urbano usado tradicionalmente, que consistia em calcular as vantagens e os custos que derivavam de uma obra, e não utilizava critérios de cálculo claros e compreensíveis para todas as pessoas. Ele apontou outras vantagens de seu método em relação ao tradicional:

O método, além de racional, é explícito. Qualquer outra pessoa que aceite este método e suas demonstrações provavelmente chegará às mesmas conclusões. Esse aspecto contrasta com o tipo de planejamento que geralmente é realizado, no qual os critérios são frequentemente obscuros e difíceis de distinguir. Além disso, esse método permite uma melhoria muito

\footnotetext{
30"Normalmente, los mapas de usos del suelo y las propuestas de ordenación del suelo muestran categorias de uso amplias. Los mapas del presente estudio se asemejan más a mosaicos que a carteles, pues son el resultado de pedir al terreno que manifieste propiedades discretas que, al superponerlas, ponen de manifiesto una gran complejidad. Pero esta es la verdadera complejidad de la oportunidad y de la limitación. La apariencia anárquica se debe a que nos hemos acostumbrado a la monótona reqularidad de la zonificación, porque no estamos acostumbrados a percibir la verdadera diversidad del medio natural, ni a responder, con nuestros planes, a esta diversidad."
} 
importante do método de planejamento, já que a comunidade poderia usar seu próprio sistema de valores. (MCHARG, 2000, p. 105, tradução nossa ${ }^{31}$ ).

O Planejamento Ecológico proposto por McHarg no livro Design with Nature, utilizavase de ferramentas como a cartografia, que contemplava diversas informações, analisadas por um sistema de valores, com a finalidade de determinar a aptidão do lugar de forma a orientar as intervenções sobre o solo. O processo começava com a obtenção dos dados primários sobre uma determinada região representados em mapas, tais como geomorfologia, altimetria, pedologia, hidrologia, vegetação, fauna, interesse histórico e cultural, entre outros, que isolados não contribuíam efetivamente para o método: esses dados precisavam ser interpretados e reorganizadas dentro de um sistema de valores. Dentro de cada uma dessas categorias de informações eram selecionados os fatores de maior relevância para uso do solo almejado, em seguida os fatores eram classificados em uma escala de valores representados na cartografia através de intensidade de cor. Cada um desses mapas era feito em transparências, que eram sobrepostas e fotografadas, resultando em uma fotografia com a soma de todos os valores. A partir desta imagem era elaborado um mapa síntese, que apresentava o gradiente de valores, indicando a aptidão de uma área (suitability map) para certo uso ou usos, pois eles podiam coexistir de maneira compatível como indicado anteriormente. Supondo que os tons mais escuros representassem valores positivos, onde houvesse maior coincidência deles estariam as áreas mais adequadas para o uso do solo pretendido e, consequentemente, os tons mais claros indicariam as áreas menos adequadas. Destaca-se o fato de que cada intervenção deveria oferecer benefício social máximo e custo social mínimo (MCHARG, 2000).

O método também incorporou outros recursos gráficos como cortes do relevo, perspectivas e fotografias, que permitiam complementar a análise com informações na escala humana. McHarg (2000) acreditava na inovação de seu método por ser racional e baseado em dados científicos obtidos em fontes seguras e, ainda que fosse impreciso ou limitado para algumas situações, seria mais completo que os utilizados tradicionalmente. Além disso, o

\footnotetext{
31“El método, además de ser racional, es explícito. Cualquier otra persona que acepte dicho método y susdemonstraciones es probalble que llegue a las mismas conclusiones. Este aspecto contrasta con el tipo de planificación que se realiza habitualmente, en la que los criterios resultan a menudo oscuros y difíciles de distinguir. Además, este método permite una mejora muy importante del método de planificación ya que la comunidad pude utilizar su propio sistema de valores."
} 
método poderia ser reproduzido por qualquer pessoa, acadêmicos, técnicos, estudiosos, bem como a população leiga, permitindo que a comunidade construísse seu próprio sistema de valores e, exigissem que os empreendimentos considerassem os valores estabelecidos.

Um dos exemplos da aplicação do método é o estudo para identificar a melhor localização para a construção de uma rodovia, a Richmond Parkway, na Califórnia (EUA). A análise contou com uma série de critérios separados, como benefícios e custos, e elementos que seriam facilmente quantificáveis, por exemplo o valor da terra e dos edifícios, que refletiam um sistema de valores econômicos. Enquanto os processos naturais e os interesses históricos e cênicos seriam avaliados pela qualidade e classificados por ordem de importância. Estes dados foram expressos em mapas através de três intensidades de cinza que representavam os valores, sendo os tons escuros para custos elevados (figura 10 e 12). É importante relembrar que McHarg identificava os processos sociais e os processos naturais como valores sociais. Para estes processos estabeleceu uma hierarquia referente às dificuldades ou facilidades para a construção da rodovia em questão, por exemplo, quanto aos tipos de rocha; quanto à avaliação de áreas propensas à inundação e à erosão do solo; quanto à classificação da qualidade de um bosque baseando-se em suas espécies, números de indivíduos etc.; quanto à beleza paisagística; quanto à importância de edifícios históricos, entre outros.

Neste estudo foram produzidos dois mapas síntese. O primeiro apresentou os obstáculos fisiográficos (figura 11), referentes à sobreposição dos fatores ortodoxos, assim denominados por geralmente serem empregados pelos engenheiros no modelo de planejamento tradicional: declividade, drenagem superficial, drenagem do solo, leito rochoso, base rochosa, susceptibilidade à erosão. O segundo (figura 13), referia-se ao conjunto de valores sociais, composto pela soma (sobreposição das transparências) dos fatores que representavam riscos à vida e à propriedade, por exemplo, as zonas vulneráveis à inundação gerada por furacões, assim como os outros fatores que configuravam as avaliações dos processos naturais e sociais: valores históricos, hídricos, cênicos, recreativos, residenciais florestais, de fauna e flora, institucionais. Ao sobrepor os dois mapas síntese, que também foram elaborados em transparências, revelaram-se as áreas em tons mais claros, onde os 
custos sociais e econômicos seriam menores (figura 14), determinando-se, portanto, a localização mais adequada para a rodovia.
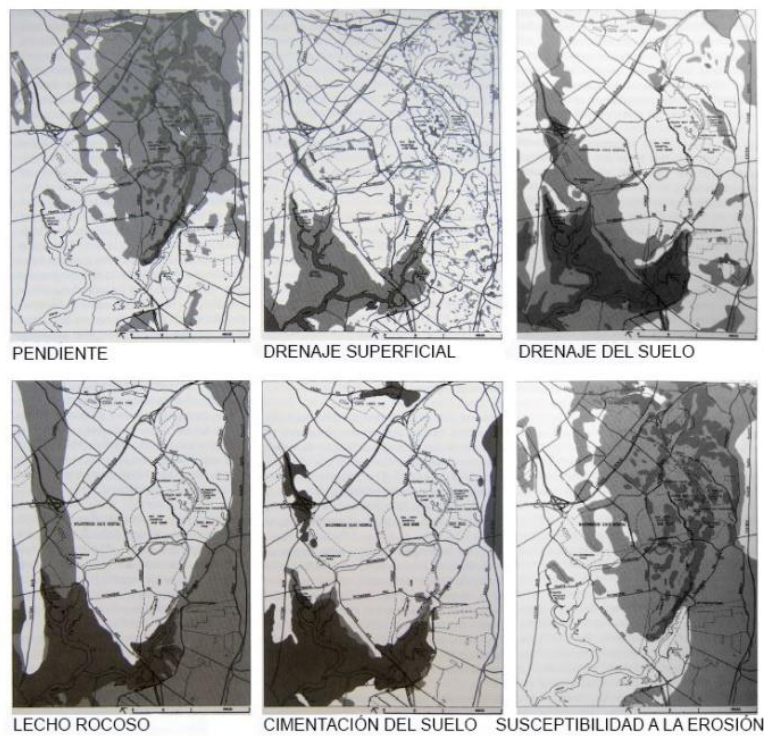

Figura 10: Cartografias indicando a leitura da região para a Richmond Parkway. Obstáculos fisiográficos: Mapa de declividade, Mapa de drenagem superficial, Mapa de drenagem do solo, Mapa do leito rochoso, Mapa de base rochosa, Mapa de susceptibilidade à erosão.

Fonte: MCHARG, 2000, p. 36.

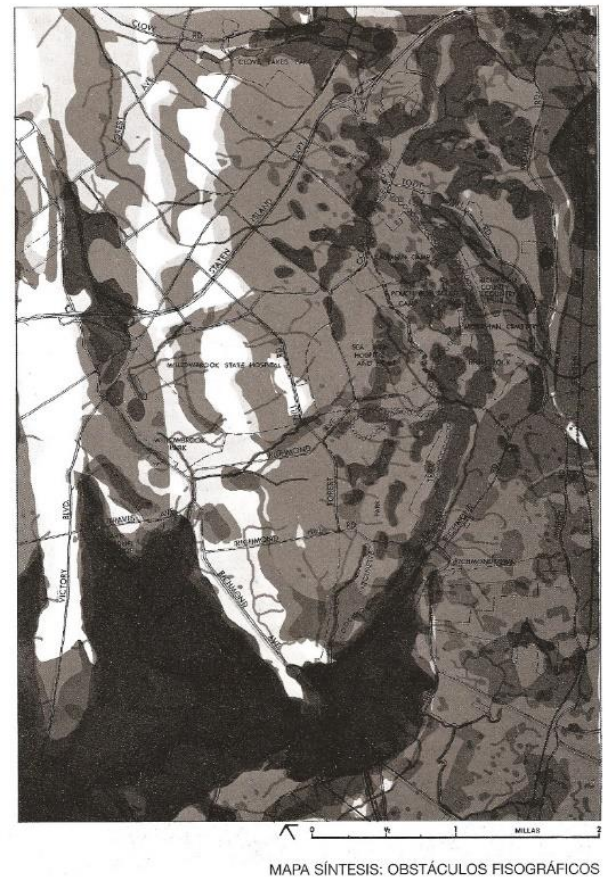

Figura 11: Mapa síntese: Obstáculos fisiográficos.

Fonte: MCHARG, 2000, p. 37. 


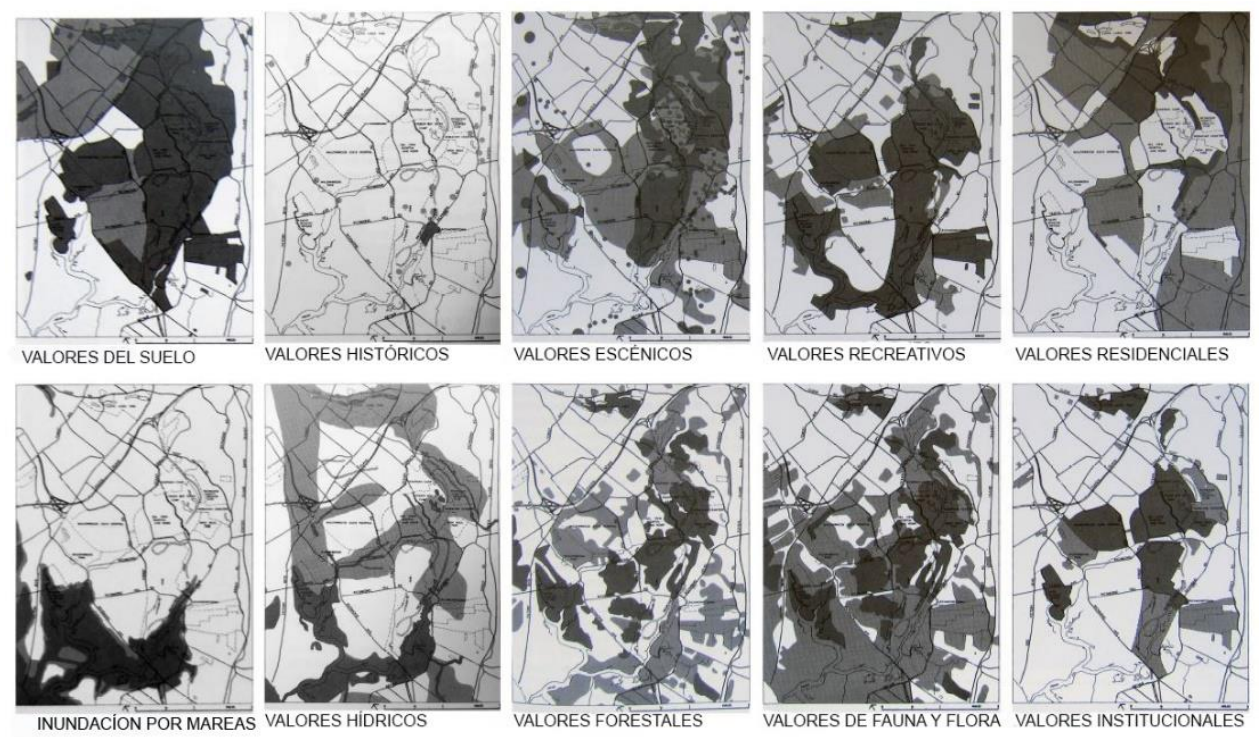

Figura 12: Cartografias indicando a leitura da região para a Richmond Parkway. Valores: Mapa de valores do solo, Mapa de valores históricos, Mapa de valores cênicos, Mapa de valores recreativos, Mapa de valores residenciais, Mapa de inundação por marés, Mapa de valores hídricos, Mapa de valores florestais, Mapa de valores de fauna e flora, Mapa de valores institucionais.

Fonte: MCHARG, 2000, p. 38-39.

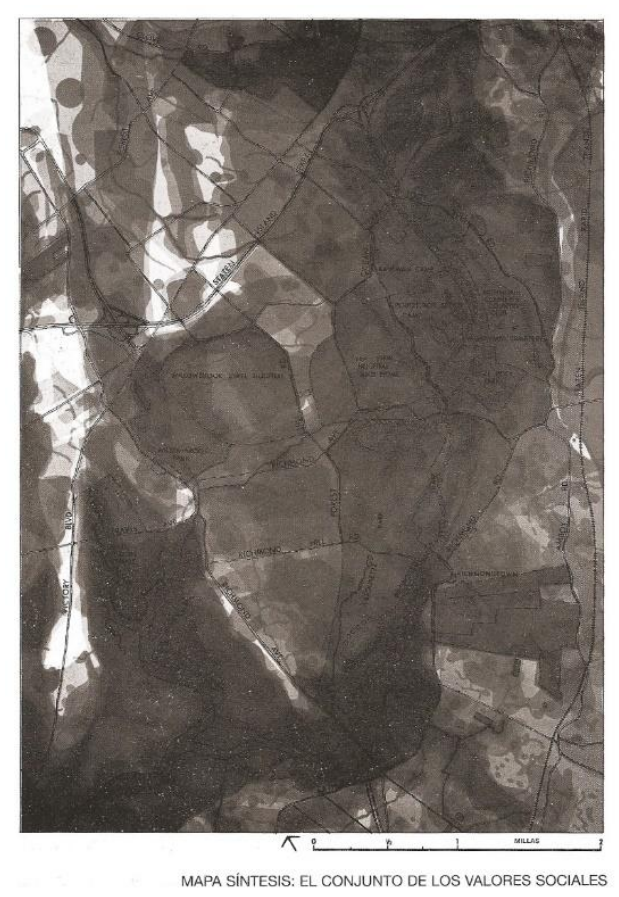

Figura 13: Mapa síntese: $O$ conjunto dos valores sociais.

Fonte: MCHARG, 2000, p. 40. 


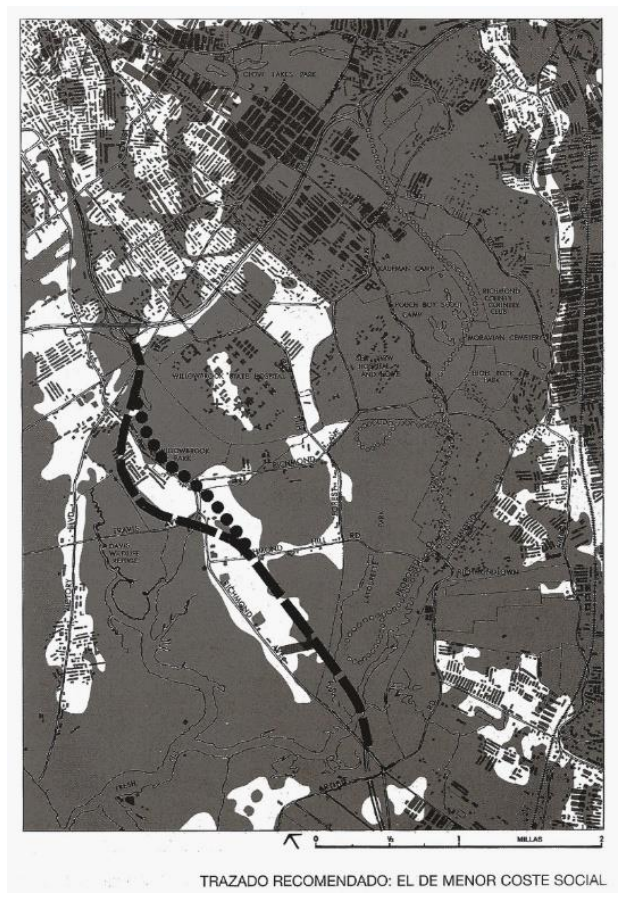

Figura 14: Cartografia indicando a melhor localização para a Richmond Parkway. Fonte: MCHARG, 2000, p. 41.

Outro exemplo da aplicação do Planejamento Ecológico foi o estudo para o sistema de espaços livres na região metropolitana de Filadélfia (EUA), em que McHarg investigou como ponderar o papel da natureza na cidade. Este arquiteto acreditava que população deveria reconhecer os processos naturais em benefício próprio, dadas as interações existentes entre estes processos e as atividades humanas, e devido às características intrínsecas da natureza determinarem oportunidades e limites às intervenções humanas. Nesse sentido, parecia razoável que certos locais se apresentassem inadequados à urbanização e, portanto, devessem ser protegidos por lei, fato bastante incomum. Esta foi uma ação pioneira do arquiteto, pois a leitura do território fornece diretrizes para a feitura do corpo legal.

Mas não há preocupação semelhante, declarada legalmente, que garanta que uma casa não tenha sido construída em uma zona de inundação, ou sobre sedimentos não consolidados, ou em áreas de movimentos sísmicos, ou de furacões, ou em uma floresta onde os incêndios proliferam, ou em áreas suscetíveis a subsidência ou deslizamentos de terra.

[...]

Esses danos e perdas de vidas podem ser devidos, na pior das hipóteses, a uma negligência punível e, na melhor das hipóteses, a uma ignorância 
imperdoável, sem, portanto, ter a proteção de regulamentos ou leis governamentais. (MCHARG, 2000, p. 55, tradução nossa ${ }^{32}$ ).

Ele alertava para o modo expansivo pela qual a urbanização se ampliava continuamente sobre o perímetro da cidade, afastando cada vez mais a população dos espaços livres, principalmente nas áreas centrais. A melhor localização dos espaços livres na cidade seria então determinada pelos valores relacionados aos processos naturais e pelas oportunidades e limitações intrínsecas a eles, de forma a promover a segurança da população e a proteção da natureza e sua fruição. Deste modo, mais que procurar um critério uniforme de distribuição dos espaços livres, seria necessário destacar aspectos diferenciais de cada processo natural e, a partir disso, encontrar a atividade mais compatível, o que McHarg (2000) chamou de modelo positivo de desenvolvimento urbano.

Ao investigar o ciclo hidrológico na região (figura 15) ele atentou para a água como um indicador da interação entre os processos naturais e, deste modo, como a gestão da terra afetaria a água e vice-versa. Portanto, este fato seria primordial na investigação acerca dos espaços livres da cidade. Tendo em vista esta interação, para os estudos dos espaços livres da Filadélfia, elegeu oito aspectos dominantes do processo natural e classificou-os em uma ordem referente à adequação para urbanização (figura 16).

\footnotetext{
32"Pero no hay una preocupación similar, plasmada legalmente, que garantice que una casa no haya sido construida en una zona inundable, o sobre sedimentos sin consolidar, o en zonas de movimientos sismicos, o de huracanes, o en un bosque donde proliferan los incendios, o en zonas susceptibles de padecer hundimientos $o$ corrimientos de tierras.

[...]

Estos daños y estas pérdidas de vida podrían deberse, en el peor de los casos, a una negligencia punible, y en el mejor, a una ignorancia imperdonable, sin que por ello tengamos la protección de normativas gubernamentales o de leyes."
} 

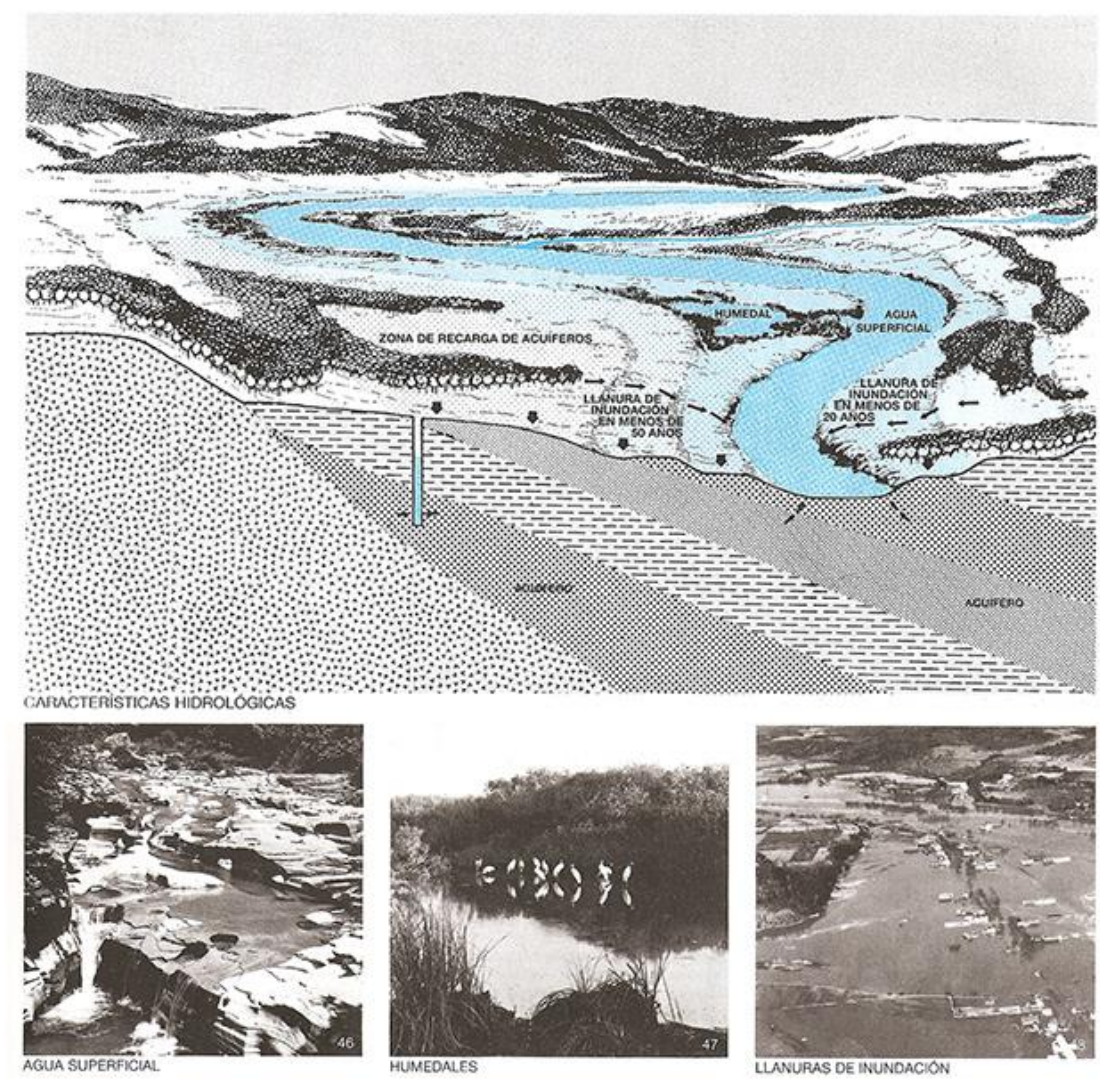

Figura 15: Representação das características hidrológicas e fotografias que compõem a leitura da região metropolitana da Filadélfia.

Fonte: MCHARG, 2000, p. 59.

\begin{tabular}{|c|c|}
\hline $\begin{array}{l}\text { Valor del proceso } \\
\text { natural; } \\
\text { Grado de intolerancia }\end{array}$ & $\begin{array}{l}\text { Idoneidad intrinseca } \\
\text { para uso urbano }\end{array}$ \\
\hline Agua superficial & Terrenos Ilanos \\
\hline Humedales & Bosques, zonas \\
\hline Ulanuras de inundación & arboladas \\
\hline $\begin{array}{c}\text { Zonas de recarga } \\
\text { de acuiferos }\end{array}$ & $\begin{array}{l}\text { Pendientes } \\
\text { pronunciadas }\end{array}$ \\
\hline Acuiferos & Acuíferos \\
\hline $\begin{array}{l}\text { Pendientes } \\
\text { pronunciadas }\end{array}$ & $\begin{array}{c}\text { Zonas de recarga } \\
\text { de acuíferos }\end{array}$ \\
\hline $\begin{array}{l}\text { Bosques, zonas } \\
\text { arboladas }\end{array}$ & $\begin{array}{l}\text { Llanuras de inundación } \\
\text { Humedales }\end{array}$ \\
\hline Terrenos llanos & Agua superficial \\
\hline
\end{tabular}

Figura 16: Aspectos dominantes do processo natural, ordenados conforme seu valor e sua resistência a utilização humana; e hierarquia da idoneidade para uso urbano para o sistema de espaços livres na região metropolitana da Filadélfia.

Fonte: MCHARG, 2000, p. 59. 
McHarg identificou um conflito nesta hierarquia, pois uma mesma área possibilitava múltiplos usos, a exemplo dos solos agrícolas férteis que frequentemente eram requeridos para edificação. Na resolução deste impasse (figura 17) considerou que as terras agrícolas primárias de alta qualidade eram escassas na metrópole, portanto, deveriam ser destinadas ao uso agrícola. Vale destacar nesse estudo a crescente aceitação da exclusão das planícies de inundação (várzeas) para localizar áreas residenciais, no entanto, sendo permitidos usos conectados a elas, a saber, portos, marinas, indústria relacionada à água ou usos não danificáveis pelas inundações como espaços livres institucionais, atividades agrícolas, florestas e atividades recreativas (MCHARG, 2000). Era possível modificar as características intrínsecas de um local para um determinado uso, sendo, porém, demandados grandes investimentos de capital e, às vezes, altos custos sociais.

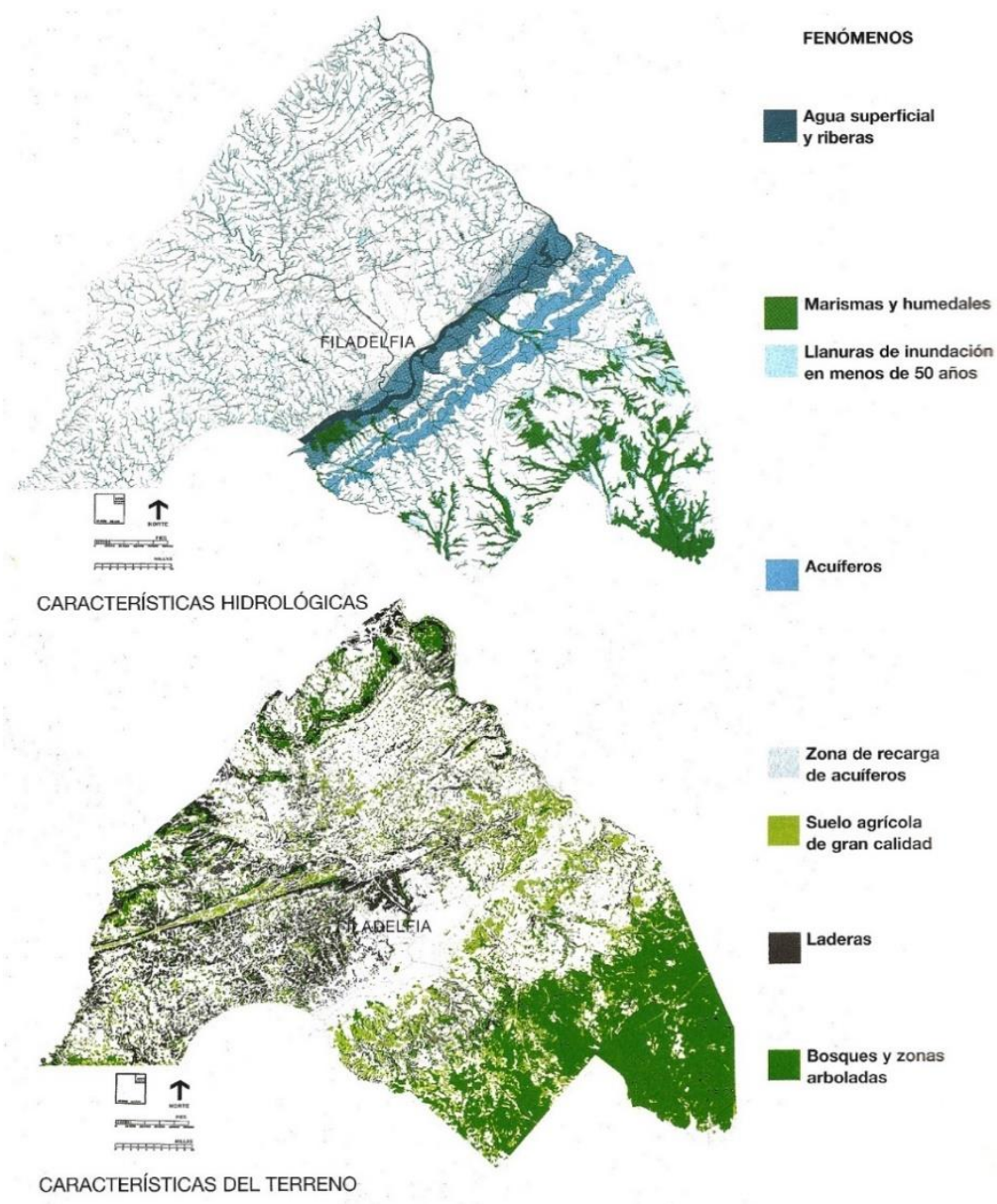

Figura 17: Cartografia síntese indicando características hidrológicas e características do solo da região metropolitana da Filadélfia. Fonte: MCHARG, 2000, p. 62. 
McHarg explicou que o objetivo dessa investigação era mostrar que os processos naturais compõem um sistema, que interagem com as alterações realizadas sobre eles e, além do mais, constituem valores sociais indispensáveis ao planejamento urbano. Deste modo, identificou a necessidade de legislações e políticas públicas que assegurassem esses valores sociais e regulassem o impacto das intervenções humanas sobre os processos naturais.

A investigação deste arquiteto tem a dimensão ecológica como questão central, no entanto, ao analisar o seu método e compreender seus princípios é perceptível a visualização de outras dimensões incorporadas como a histórica, a cultural, a cênica, aproximando-se do campo da Paisagem. Embora não utilize o vocábulo "Paisagem", ele permeia todo método e está explícito enquanto entende que um local é "a soma de uma série de processos históricos, físicos e biológicos, todos eles dinâmicos, que constituem valores de interesse social" (MCHARG, 2000, p. 104).

As questões abordadas por McHarg representaram um avanço para o planejamento urbano em congruência com os valores da paisagem. Tal relevância se alinhou com a consciência ecológica do período e sua abordagem pioneira influenciou o trabalho de seus colegas contemporâneos e seguidores Michael Hough, Richard Forman e Anne Spirn.

\subsection{Ressonâncias do Planejamento Ecológico de lan McHarg}

\section{Michael Hough}

Michael Hough (1928-2013) foi um arquiteto da paisagem que atuou no Canadá na prática profissional e no ensino, contribuindo para o momento de conscientização da importância da questão ambiental ${ }^{33}$. Seu trabalho tinha como propósito demonstrar novas formas de modelar paisagens urbanas, planejando e projetando, com menor custo e maior valor social se comparadas ao planejamento tradicional, normalmente baseado em questões eminentemente econômicas e que pouco contribuíam para um ambiente saudável.

\footnotetext{
${ }^{33}$ Hough mudou-se da Inglaterra para o Canadá em 1959, lecionou na Universidade de Toronto, onde fundou programa de Arquitetura da Paisagem em 1965. Posteriormente entre os anos de 1970 a 2005 foi professor na Faculdade de Estudos Ambientais da Universidade de York, em Ontario, Canadá. Trabalhou como arquiteto paisagista no escritório Michael Hough \& Associates, fundado por ele em 1963, e foi membro da Sociedade de Arquitetos Paisagistas. Além de escrever diversos livros sobre o tema, desenvolveu notáveis projetos paisagísticos, sendo seu trabalho reconhecido através de premiações. Fonte: Homepage The Cultural Landscape Foundation, disponível em: <https://tclf.org/pioneer/michael-hough>. Acesso em: 16 ago. 2019.
} 
Em seu livro "Natureza e Cidade" ${ }^{34}$ ele discorreu sobre a ideia de que o ser humano está imerso na natureza, está interconectado aos outros processos que nela ocorrem e por isso deve considerá-la no desenvolvimento da cidade. Hough (1998) defendia a tese de que o planejamento urbano deveria acontecer em consonância com o ambiente físico, reconciliando a humanidade e a natureza.

A dependência entre os sistemas de vida, o desenvolvimento interconectado dos processos físicos e vitais da terra, o clima, a água, as plantas e os animais, a contínua transformação e reciclagem dos materiais vivos e não vivos são os elementos da biosfera autossuficiente que permitem a vida na terra e que dão lugar à paisagem física. Constituem os elementos determinantes que dão forma a todas as atividades humanas sobre a terra (HOUGH, 1998, p. 5, tradução nossa ${ }^{35}$ ).

A maneira como se desenvolveram as cidades, principalmente o crescimento intenso após a Segunda Guerra Mundial, modificou profundamente a paisagem física e a percepção das pessoas sobre os ciclos naturais. O aperfeiçoamento tecnológico proporcionou o controle da natureza, que pode ser observada nas paisagens formadas pelos gramados bem cuidados, canteiros de flores, chafarizes e fontes de água e árvores enfileiradas encontrados nos espaços formalmente organizados, que demandam manutenção constante e grande gasto de energia. De acordo com Hough (1998), esse modo de conformação espacial era baseado em valores estéticos e tinha pouca conexão com a dinâmica dos processos naturais, consequentemente acarretou desequilíbrios em ecossistemas que eram autossuficientes.

Ao analisar as paisagens na evolução da cidade pré-industrial até a cidade contemporânea ele identificou mudanças significativas relacionadas à percepção da natureza. Historicamente, a cidade pré-industrial ainda guardava relações mais diretas com a área rural através de conexões visuais e funcionais com o campo, que na cidade moderna foram se perdendo. O cultivo tradicional das terras nas bordas das cidades e, que com elas estabelecia relações, foi substituído, na cidade moderna, pela agricultura industrializada e a terra tornou-

\footnotetext{
${ }^{34} \mathrm{O}$ livro foi publicado em 1984 e, posteriormente, passou por revisão, conforme Hough explicou, para se adequar às mudanças ocorridas na percepção que a sociedade tinha sobre a natureza e o contexto urbano. Consultou-se a versão em espanhol de 1998, traduzida da versão inglesa de 1995 intitulada "Cities and Natural Process".

35 "La dependencia de un sistema de vida com otro, el desarrollo interconectado de los procesos físicos y vitales de la tierra, el clima, el agua, las plantas y los animales, la continua transformación y reciclado de los materiales vivos y no vivos, son los elementos de la autosuficiente biosfera que permiten la vida en la tierra y que dan lugar al paisaje físico. Constituyen los elementos determinantes que dan forma a todas las actividades humanas sobre la tierra."
} 
se alvo da especulação imobiliária. A inserção de espaços verdejados na figura do parque urbano no período industrial estava relacionada ao ócio, ao lazer e a recreação, propósitos diferentes da função do campo ou dos espaços livres urbanos dos antigos assentamentos que comportavam pomares e pastagens para gado.

Para Hough (1998), à medida que as cidades se expandiam e se industrializavam, ocorria o afastamento das áreas rurais e a separação psicológica entre os ambientes urbano e rural.

Os conceitos "humanidade" e "natureza" há muito são entendidos como problemas separados. Essa dicotomia teve profunda influência no pensamento da humanidade: por um lado, as cidades onde as pessoas vivem e, por outro, as regiões não urbanas, além da cidade, onde a natureza vive. Nesta cultura, gerando as disciplinas de intervenção - engenharia, construção, planejamento e projeto -, essa separação também teve um efeito profundo no controle, não apenas da natureza, mas também do comportamento humano. Dessa maneira, o caráter do design formal não lida com as forças inatas que estão moldando o ambiente humano, nem com as necessidades das comunidades multiculturais que hoje são a norma na maioria das cidades de hoje. (HOUGH, 1998, p. 9-10, tradução nossa ${ }^{36}$ ).

Hough (1998) apontou que o ambiente urbano distanciou o ser humano dos processos naturais que sustentam a vida e ainda exerceu grande pressão sobre eles, mesmo dependendo destes processos para a entrada de recursos, energia e descarte de resíduos. Conforme o autor, apesar de intensamente modificados, os sistemas naturais mantêm seu funcionamento e se manifestam, seja através da erva daninha que brota em locais degradados ou da água que mostra sua força depois de uma chuva intensa. Hough (1998) acreditava que a forma urbana era resultante das forças naturais, esta forma era intensificada pelas transformações econômicas, políticas, demográficas e sociais, em um processo evolutivo constante, que imprimia nas paisagens a história natural e humana.

Os sistemas de abastecimento de água e drenagem não deixam indicação de que a água fornecida pela torneira da cozinha se origine nas florestas e paisagens das bacias superiores, ou que a chuva que cai nos telhados e nos

\footnotetext{
36"Los conceptos "humanidad" y "naturaleza" han sido entendidos durante mucho tiempo como problemas separados. Esta dicotomía ha tenido una profunda influencia en el pensamiento de la humanidad: por una parte, las ciudades donde habitan las personas, y por otra las regiones no urbanas, más allá de la ciudad, donde vive la naturaleza. En esta cultura, generadora de las disciplinas de la intervencion - ingeniería, construcción, planificación y diseño -, esta separación ha tenido también un profundo efecto en el control, no sólo de la naturaleza, sino tambiem del comportamiento humano. De este modo el carácter del diseño formal no se ha ocupado de las fuerzas innatas que van perfilando el entorno humano, ni de las necessidades de las comunidades multiculturais que hoy son la norma en la mayoria de las ciudades actuales."
} 
pavimento e que desaparece sem deixar vestígios nas pias e nos esgotos subterrâneos, faz parte de um ciclo hidrológico contínuo. É difícil associar espécimes de grama e árvores de parques e jardins urbanos, aquelas plantas trazidas da Coréia e do Himalaia e esse gramado mantido como uma mesa de bilhar, com a comunidade diversificada de plantas que convertem a luz solar em energia, armazenem carbono e produzam os alimentos e materiais necessários para a sobrevivência. [...] Os esgotos sanitários e o caminhão de lixo interrompem o ciclo de vida de nutrientes e materiais do sistema natural. $\mathrm{O}$ ambiente urbano nos isola dos processos naturais e humanos que sustentam a vida. (HOUGH, 1998, p. 14-15, tradução nossa ${ }^{37}$ ).

Embora o arquiteto já identificasse tentativas de reconexão com a natureza através do reconhecimento dos ciclos naturais no planejamento, ainda entendia ser necessário reexaminar os fundamentos do projeto urbano na direção de um ambiente sustentável. Assim, recomendava a estratégia da ecologia urbana, juntamente com os objetivos sociais e econômicos, como base de ação para modelar paisagens urbanas.

No livro 'Cidade e Natureza' (1998) ele elencou os princípios de projeto urbano que embasavam sua perspectiva de planejamento das cidades. O princípio da economia de meios, referia-se a ideia de usar o mínimo de energia para alcançar o máximo de benefícios ambientais, econômicos e sociais, o que ilustrou com o processo de reciclagem e a reutilização de materiais. O princípio da diversidade abordava a relevância da variedade de lugares e de paisagens para tornar a vivência na cidade mais agradável e saudável, o que também tornava a comunidade menos suscetível em momentos de dificuldades, pois "[...] quanto maior a dependência de uma única fonte de energia, mais vulnerável será a comunidade urbana em momentos de necessidade" (HOUGH, 1998, p. 23, tradução nossa ${ }^{38}$ ). A conexão era o princípio referente ao entendimento do local com relação ao seu contexto, isto é, o entendimento de que os sistemas estavam interligados e, portanto, exerciam influências uns nos outros. A educação ambiental também era um princípio e se relacionava à desmitificação da natureza

\footnotetext{
37 "El abastecimiento de agua y los sistemas de desagüe no dejan indicación alguna de que el agua suministrada a través del grifo de la cocina tiene su origen en las forestas y los paisajes de las cuencas superiores, o de que la lluvia que cae sobre los tejados y el pavimento y que desaparece sin dejar rastro en los sumideros y las alcantarillas subtierráneas, es parte de un ciclo hidrológico continuo. Resulta dificil asociar la hierba y los ejemplares arbóreos de los parques urbanos y de los jardines, esas plantas traídas de Corea y del Himalaya, y ese césped mantenido como una mesa de billar, com la diversa comunidad de plantas que convierten la luz solar en energía, almacenan carbón y producern los alimentos y materiales necesarios para la supervivencia.[...] Las alcantarillas sanitarias y el camión de la basura rompen el ciclo vital de los nutrientes y de las materias de los sistemas naturales. El ambiente urbano nos aisla de los procesos naturales y humanos que sostienen la vida." 38 "[...] cuanto mayor es la dependência de uma única fuente de energia, más vulnerable será uma comunidade urbana em épocas de necessidade".
} 
como algo separado da cidade, esclarecendo que ela está presente no cotidiano das pessoas. A aproximação à natureza era o princípio que aconteceria ao explicitar os processos que sustentam a vida, encobertos com o passar do tempo pelo modo de vida citadino e pela evolução tecnológica. As pessoas estavam habituadas a comprar alimentos no supermercado, a ter energia elétrica e água em suas residências, a descartar o lixo nas lixeiras, perdendo as evidências do funcionamento desses processos e compreendendo a natureza como algo distante e externo à cidade, consequentemente, não se sentindo responsáveis por ela.

O autor reconheceu os desafios em conciliar os ciclos naturais e o desenvolvimento humano sujeito aos valores econômicos e conscientizou-se de que uma postura preservacionista não seria viável, portanto, pretendia demonstrar formas realistas de modelar a paisagem. Deste modo, o último princípio intentava a melhoria ambiental através do desenvolvimento humano, buscando integrar de forma positiva o ser humano aos ciclos naturais, ou seja, buscando meios de avançar que também beneficiassem o ambiente físico a ser transformado.

Pretendemos encontrar uma linguagem de desenho cuja inspiração derive da realização da maioria das oportunidades disponíveis; uma linguagem que reestabeleça o conceito de paisagens multifuncionais, produtivas e operacionais que integram a ecologia, as pessoas e a economia. Como as questões ambientais estão se tornando cada vez mais importantes para garantir o futuro não apenas das cidades, mas também do planeta, é cada vez mais urgente encontrar novas maneiras de moldar as paisagens futuras (HOUGH, 1998, p. 31, tradução nossa ${ }^{39}$ ).

O autor mostrou os efeitos negativos que a urbanização fundamentada na prática de projeto convencional causou em uma bacia hidrográfica no Canadá. De acordo com Hough (1998), os ecossistemas fluviais refletem a realidade das ações ocorridas na bacia hidrográfica ao qual pertencem. O Don é um rio de relevância para a cidade de Toronto que teve sua bacia intensamente ocupada e bastante modificada pela ação antrópica, suas águas foram poluídas e os ecossistemas prejudicados. A comunidade não estabelecia contato com este rio, que era

\footnotetext{
39 "Pretendemos encontrar un lenguaje de diseño cuya inspiración derive de la realización de la mayoría de las oportunidades disponibles; un lenguaje que restablezca el concepto de los paisajes multifuncionales, productivos y operativos que integren la ecología, la gente y la economía. Como los problemas medioambientales están adquiriendo una importancia creciente para garantizar el porvenir no sólo de las ciudades, sino también del planeta, cada vez es más urgènte conseguir nuevas maneras de conformar los futuros paisajes."
} 
percebido como limite à cidade, como um vazio ou um corredor por onde passavam vias e ferrovias.

Entretanto, por uma iniciativa popular formou-se The Task Force to Bring Back the Don (A Força-Tarefa para trazer de volta o Don), uma organização ${ }^{40} \mathrm{com}$ a finalidade de recuperar a parte mais degrada do rio (Lower Don), que passa pela Grande Toronto e desagua no lago Ontário, além de propor ações de melhorias continuadas ao longo do tempo envolvendo a bacia em sua totalidade. Os objetivos eram: reestabelecer a diversidade ecológica na parte baixa do vale, agregando sua história cultural aos valores humanos e não humanos; desenvolver estratégias recreativas e educacionais que considerassem a natureza e as funções do vale, de forma a reaproximar rio e comunidade; reconectar o rio com o lago. Para alcançar tais objetivos exigia-se a compreensão da interligação entre os sistemas da natureza e humanos e a recuperação do ecossistema hidrológico.

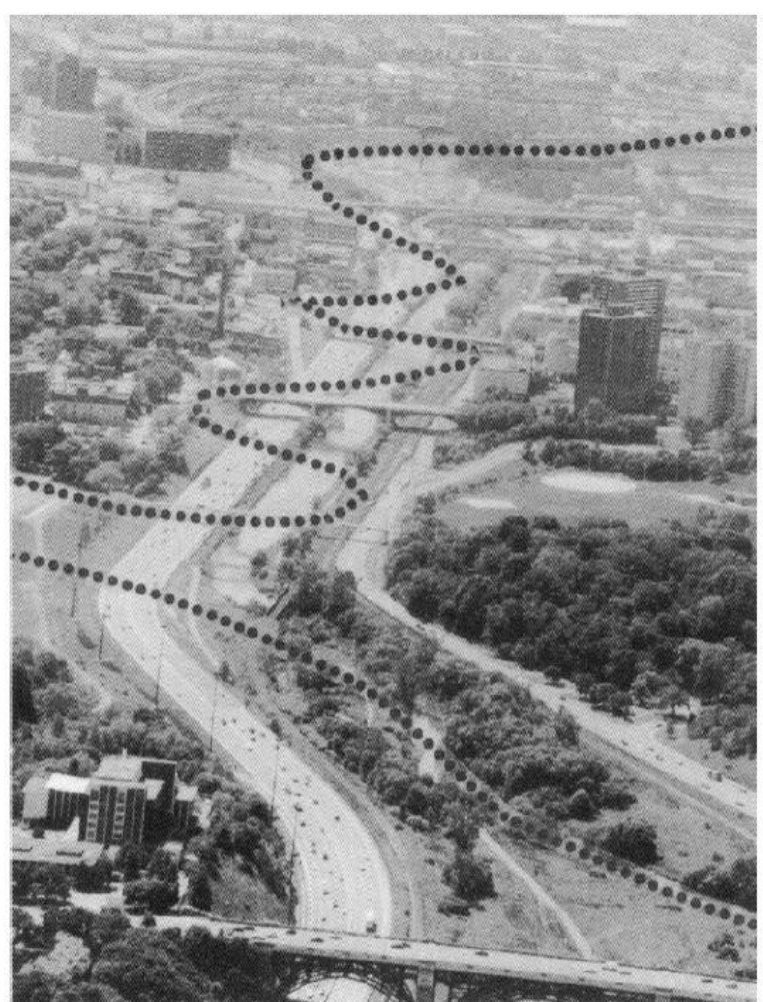

Figura 18: Sobreposição dos meandros originais (pontilhado) do rio Don antes da urbanização. Fonte: HOUGH, 1998, p. 56.

\footnotetext{
40 Organização formalizada em 1990 pela prefeitura de Toronto.
} 
A estratégia de recuperação partiu da análise dos antecedentes históricos desde sua formação geológica até os primeiros assentamentos humanos, passando pela reconstituição dos habitats, explicitando o papel da vegetação para manutenção dos ciclos naturais. O rio era percebido como obstáculo à expansão urbana, suas enchentes causavam prejuízos e os pântanos em seu delta eram considerados insalubres, desta forma, a solução adotada naquela época foi a canalização, a construção de um porto na foz e a implantação do sistema ferroviário em suas margens.

A análise da Força-Tarefa identificou ao longo do vale do Don três tipos de paisagens (figura 19) com características naturais e culturais distintas que direcionariam as estratégias de intervenção. A primeira delas era a desembocadura do rio no lago, na área portuária, local por onde passava uma ferrovia elevada. Nesta parte o propósito era controlar as inundações e o fluxo de água, bem como reestabelecer a conexão com o lago Ontário. Propôs-se a regeneração de alguns meandros dentro dos limites do canal existente e lagoas, habitats para peixes, e mais próximo ao lago previu-se a recuperação do delta com seus habitats pantanosos. Em conjunto seriam adotadas medidas futuras de desenvolvimento urbano direcionadas para o uso do solo misto, com residências, comércios e indústria "verde". Na segunda paisagem, em direção montante, o rio encontrava-se canalizado em uma área reduzida. Nesse trecho de caráter mais urbano haveria um tratamento mais formal e linear, com arborização das margens, ciclovias e pistas de caminhada, locais para estar e ouvir o som da água, fazer piquenique e pescar, além de novos pontos para acessar a área. Na terceira paisagem (figura 20) os meandros originais ainda existiam e o vale ampliava-se numa grande planície de inundação na qual seriam criados pântanos e prados para melhorar a qualidade da água e controlar as inundações. As encostas seriam arborizadas, haveria caminhos, áreas para piquenique, pontos de informação. Percorrendo esta planície rio acima se acrescentaria uma quarta paisagem formada por barrancos estreitos e vegetados que se articulariam com as comunidades locais e os parques da cidade. Seria abordada ainda a questão patrimonial referente à história industrial de Toronto através da presença de edificações de uma das primeiras serralherias, que utilizava a água em seu funcionamento, localizada nas proximidades das estradas na direção montante (HOUGH, 1998). 


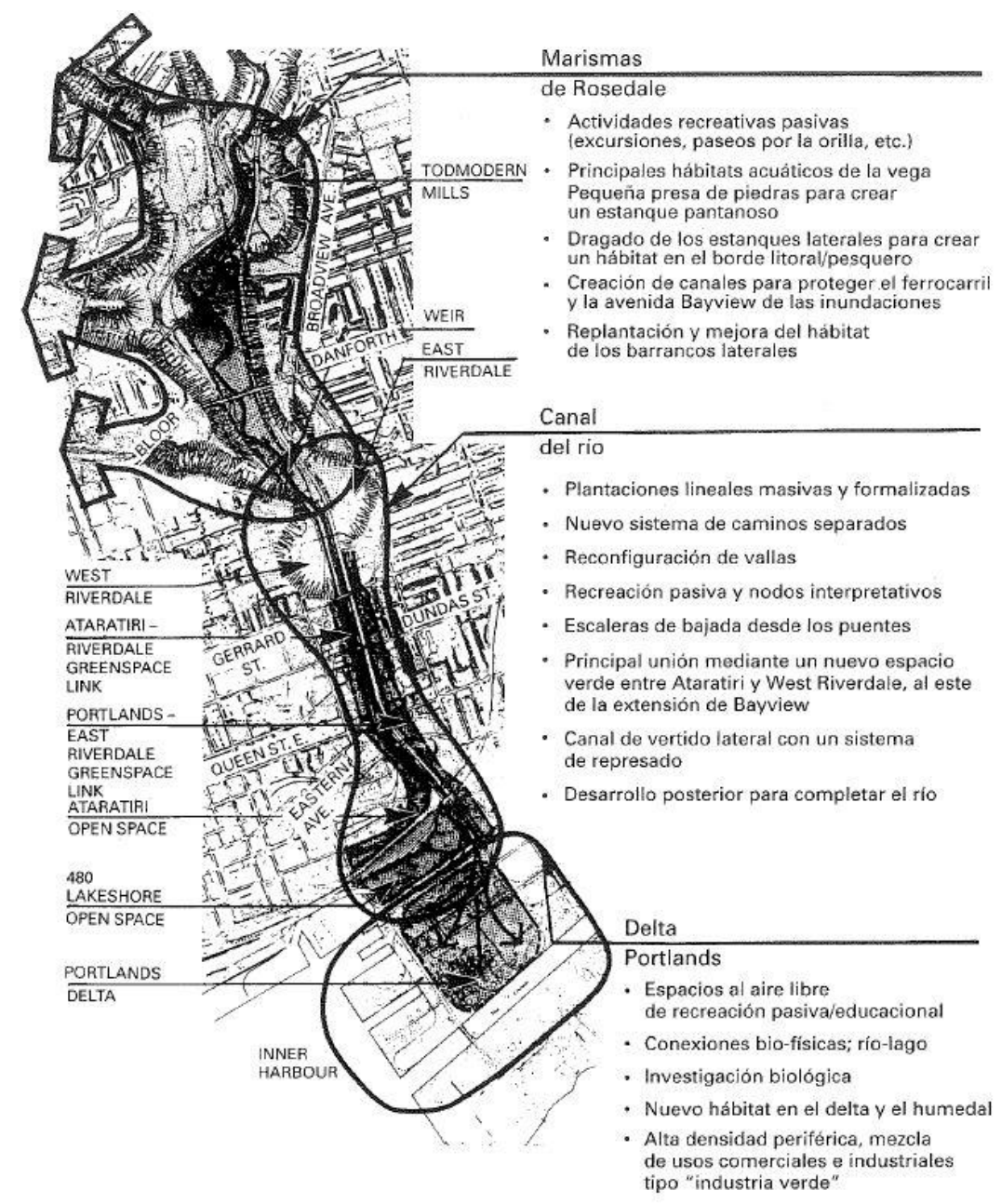

Figura 19: Plano estratégico para a parte baixa do rio Don, indicando as três unidades paisagísticas distintas.

Fonte: HOUGH, 1998, p. 63.

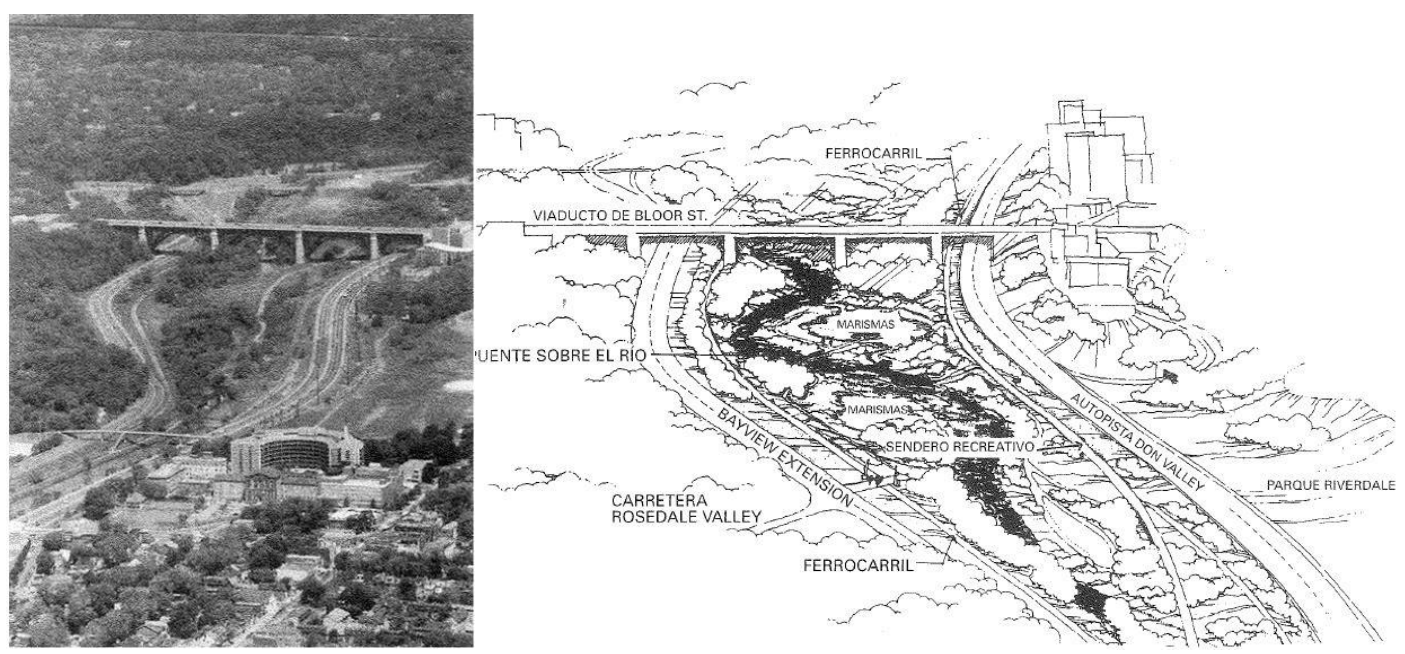

Figura 20: Fotografia do cenário existente à montante do rio Don, junto aos pântanos de Rosedale. Desenho ilustrando o mesmo trecho com as propostas para o pântano, os prados, os passeios e as áreas recreativas.

Fonte: HOUGH, 1998, p. 64-65. 
No processo de resgate do rio Don percebe-se claramente a aplicação dos princípios de projeto elaborados por Hough no livro Cidade e Natureza. Ao recuperar a vida do corpo d'água, ele pretendia explicitar e aproximar a população dos processos da natureza mediante a conexão e a vivência de experiências sensoriais nessa nova paisagem. Deste modo, a comunidade foi fundamental para a execução da proposta, que foi possível devido à articulação na escala local e regional e entre as agendas políticas e econômicas, bem como destas com os interesses privados. Além disso, foi essencial que houvesse acordos entre os diferentes níveis de governo para possibilitar a aquisição da terra para implementar o projeto.

\section{Richard Forman}

Richard Forman é considerado um dos pioneiros ecologistas da paisagem ${ }^{41}$ pelo seu trabalho que propõe utilizar princípios da biologia do ambiente para promover a convivência sustentável entre o homem e a natureza. Nascido nos Estados Unidos em 1935, ele ministrou Ecologia Urbana como professor emérito da Universidade de Harvard. Em seu livro 'Land Mosaics - The ecology of landscape and regions', publicado originalmente em 1995, colocou que o caminho para reconectar o ser humano e a natureza tem raízes na ecologia da paisagem e da região. Esta abordagem teve a contribuição de diferentes disciplinas, a saber, biologia, geografia, economia, planejamento urbano, além de outros conceitos, teorias e evidências de diferentes campos do conhecimento, que incrementaram sua compreensão. Quando cada um desses campos lidava separadamente com o uso da terra, o estudo era direcionado à um objetivo específico que muitas vezes não considerava todas as questões envolvidas referentes ao local, tendendo à degradação da superfície terrestre. De acordo com Forman (1995) a ecologia de paisagens e regiões tem uma estrutura abrangente que, ao agregar princípios de diversas disciplinas, fornece bases para a análise de uma região no sentindo de indicar seu uso mais adequado, se aproximando da sustentabilidade ecológica.

\footnotetext{
${ }^{41}$ Forman possui formação acadêmica em biologia pelo Haverford College e Ph.D. em botânica pela Universidade da Pensilvânia. Juntamente com profissionais de outras áreas, ele começou a construir as bases para o campo de estudo da ecologia da paisagem, que resultou no livro Landscape Ecology (1986) apontado como primeira síntese da ecologia da paisagem moderna. Fonte: Homepage da Universidade de Harvard, disponível em: <https://www.gsd.harvard.edu/person/richard-t-t-forman/> consultado em 29/08/2019.
} 
Formam (1995) identificou os elementos espaciais que formam o ambiente e que estão dispostos em um arranjo padrão denominado "mosaicos de terra" ${ }^{42}$. Esse padrão de mosaico é encontrado em várias escalas espaciais, da microscópica à universal. Os mosaicos terrestres na escala humana podem ser subdivididos em paisagens, regiões e continentes. Cada mosaico é composto por três elementos espaciais: fragmento, corredor, matriz (patch, corridor, matrix) que formam um padrão encontrado em qualquer escala.

O autor define fragmento como uma área relativamente homogênea e diferente do entorno, podendo ser de diferentes dimensões e formatos, como no formato alongado ou arredondado, citando os exemplos dos campos de agricultura e florestas. Corredor é um elemento linear, largo ou estreito, sinuoso ou retilíneo, que permite a interligação ou fluxo ecossistêmico, como cordilheiras, vales fluviais, litorais, faixas de subúrbio. E, por fim, matriz é uma extensa área continua e homogênea, que pode incorporar fragmentos e corredores. Tais atributos espaciais são de fácil compreensão e têm correspondentes em outras disciplinas, o que facilita o diálogo entre elas, contribuindo para subsidiar o planejamento do uso da terra (FORMAN, 1995).

Os mosaicos são heterogêneos, pois são conformados por diferentes arranjos do modelo fragmento-corredor-matriz. Esses elementos se estabelecem através de mecanismos referentes à origem física (relevo, tipos de solo etc.), às perturbações naturais (incêndios, tornados, pragas, entre outros), às ações humanas (agricultura, urbanização etc.) e aos processos biológicos. Os elementos também se vinculam hierarquicamente, isto é, em escalas diferentes, como no caso de uma paisagem florestal, constituída por bacia hidrográfica, que por sua vez contém ecossistemas locais, compostos por árvores. A questão dos fluxos também é relevante nesse processo de interligação, pois estes promovem relações tanto em um mesmo nível quanto verticalmente na hierarquia, como no exemplo de uma enchente, que pode afetar desde um ecossistema até toda paisagem. Nesse sentido, Forman (1995) ainda ressaltou a relevância do princípio espaço-tempo atuante sobre o mosaico terrestre, em que os fenômenos são mais duradouros em larga escala. Assim, o planejamento da paisagem deve

\footnotetext{
${ }^{42}$ A teoria do mosaico terrestre (land mosaics) foi inicialmente apresentada no livro "Landscape Ecology" (1986) escrito em parceria com M. Godron.
} 
considerar tais interações entre os elementos, como também seu contexto ecológico, econômico e social.

Embora os limites determinados por processos naturais, como bacias de drenagem e bio regiões, sejam teoricamente ótimos, não é aconselhável esperar a sociedade redesenhar a terra. Para acelerar o uso da ecologia no projeto, planejamento, conservação, gerenciamento e política, precisamos usar regiões e paisagens que equilibram e integram processos naturais e atividades humanas. (FORMAN, 1995, p. 14, tradução nossa) ${ }^{43}$.

De acordo com Forman (1995), paisagens e regiões são as escalas relevantes para promover a conciliação das diferentes dimensões (ecológicas, econômicas, social, entre outras) que envolvem o ambiente como um todo, criando condições para interações harmônicas entre os processos humanos e da natureza. Portanto, cabe aos planejadores conhecer o funcionamento destas paisagens a fim de permitir tomadas de decisões que corroborem essa harmonia.

\section{Anne Spirn}

A arquiteta paisagista e planejadora ambiental norte-americana Anne Spirn ${ }^{44}$ (1947-) segue os mesmos princípios do Planejamento Ecológico que seus colegas contemporâneos. Na década de 1970, ela teve a oportunidade de trabalhar com lan McHarg em seu escritório e depois, em 1986, o sucedeu como diretora do Departamento de Arquitetura e Planejamento Regional da Paisagem Urbana na Universidade da Pensilvânia. Spirn também teve contato com Richard Forman, a quem agradeceu pelas contribuições em seu livro 'O jardim de granito' $(1984)^{45}$, no qual defendeu a ideia de cidade e natureza como uma unidade.

\footnotetext{
43"Although boundaries determined by natural processes, such as drainage basins and bioregions, are theoretically optimum, it is not wise to wait for society to redraw the land. To accelerate the use of ecology in design, planning, conservation, management, and policy, we must use regions and landscapes that balance and integrate natural processes and human activities".

${ }^{44}$ Anne Whiston Spirn formou-se História da Arte no Radcliffe College em 1969, obteve o mestrado em Arquitetura da Paisagem pela Universidade da Pensilvânia em 1974. Trabalhou como projetista e planejadora no escritório Wallace McHarg Roberts and Todd na Filadélfia, de 1973 a 1977. Lecionou arquitetura paisagística na Universidade de Harvard de 1979 a 1986. Desde 1987, Spirn dirige o West Philadelphia Landscape Project, na Filadélfia, projeto que vincula o desenho da paisagem e o desenvolvimento comunitário e o gerenciamento urbano das águas pluviais. Em 2000 passou a fazer parte do corpo docente do Departamento de Estudos Urbanos e Planejamento do MIT. Fonte: Homepage de Anne Spirn, disponível em: <https://annewhistonspirn.com/>. Acesso em: set. 2019.

${ }^{45}$ Ano da primeira edição do livro.
} 
No prólogo deste livro, Spirn (1995) descreveu a Terra vista do espaço, aproximandose até à escala da cidade e depois até à escala de uma planta numa fresta de calçada. Essa descrição foi utilizada para afirmar que a cidade é um grande jardim de granito composto de outros jardins menores e que todos formam um mundo jardim. Com esta metáfora a autora pretendia chamar a atenção para o fato de que a "cidade é parte da natureza" (SPIRN, 1995, p. 20) e não algo separado dela, como a crença existente que resultou no agravamento dos problemas ambientais. Segundo a autora, os processos naturais que agem na floresta e na cidade são os mesmos.

A crença que a cidade é uma entidade separada da natureza, e até contrária a ela, dominou a maneira como a cidade percebida e continua afetar o modo como é construída. Esta atitude agravou e até causou muitos dos problemas ambientais urbanos: água e ar poluídos; recursos dilapidados ou irrecuperáveis; enchentes mais frequentes e mais destrutivas; demandas crescentes de energia e custos de construção e manutenção mais elevados do que os anteriores a urbanização; e, em muitas cidades, uma feiura generalizada. (SPIRN, 1995, p. 21).

Spirn (1995) afirmou que apesar das volumosas informações coletadas acerca da natureza até aquele momento, pouco delas foram empregadas na modelagem urbana devido às dificuldades geradas pelas mudanças nas políticas públicas, atreladas às forças econômicas e sociais. Tal conhecimento foi mais aplicado em normas para melhoria da qualidade ambiental, que geralmente são compreendidas como restritivas e punitivas. Em outros casos a natureza era considerada por seu papel estético. A motivação para escrever o livro veio da dificuldade de encontrar publicações em que o conhecimento estivesse resumido e aplicado ao projeto urbano, além de outras motivações de ordem pessoal.

O primeiro contato com a arquitetura paisagística foi através dos escritos de Olmsted, enquanto ela ainda era estudante de história da arte. Para a autora, este arquiteto da paisagem via nos parques urbanos estreita ligação com a melhoria dos problemas ambientais e sociais da cidade daquele período, questões que são bastante atuais. Deste modo, ela considerou o sistema de parques projetado por Olmsted no final do século XIX para a cidade de Boston, o Emerald Necklace, mais que um marco para o planejamento de parques, pois enfrentou os problemas ambientais referentes a enchentes e a qualidade das águas, para além da recreação que os parques usualmente proporcionam. Spirn enfatizou a necessidade de 
considerar os processos naturais hídricos no planejamento urbano, tema primordial por ser essencial à sobrevivência humana.

A natureza permeia a cidade, forjando relações entre ela e o ar, o solo, a água e os organismos vivos em seu interior e a sua volta. Em si mesmas, as forças da natureza não são nem benignas nem hostis à humanidade. Reconhecidas e aproveitadas, representam um poderoso recurso para a conformação de um hábitat urbano benéfico; ignoradas ou subvertidas, ampliam os problemas que há séculos castigam as cidades, como enchentes, deslizamentos e a poluição do ar e da água. Infelizmente, as cidades têm geralmente negligenciado e raramente explorado as forças naturais que existem dentro delas. (SPIRN, 1995, p. 15).

Em seu livro, Spirn mostrou como as cidades poderiam ser se projetadas de acordo com os processos naturais, não se opondo a eles e nem os ignorando. Para tanto, a autora indicou o reconhecimento das particularidades naturais do sítio em estudo, o que resultaria em formas urbanas memoráveis. Ela revisou as estratégias para mudanças radicais em cidades em expansão e as soluções de desenvolvimento mais apropriadas ao redesenho de centros urbanos existentes. A autora ressaltou a importância de entender que campo, periferia e cidade fazem parte de um sistema em evolução dentro da natureza. Spirn também colocou a necessidade de uma nova atitude diante da natureza, de modo a reconhecer seu valor social.

O atual processo de urbanização em escala mundial apresenta mais de $50 \%$ da população habitando as cidades, sendo ainda mais visível no Brasil, com pelo menos $85 \%$ de população urbana e tendência de crescimentos nesses números (IBGE, 2010). Estas estatísticas demonstram a necessidade de reflexão sobre as questões ambientais e de distribuição socioespacial, colocando em pauta a discussão entre artifício e natureza preconizada pelos precursores do Planejamento com a Paisagem. A historiografia desse campo disciplinar desenvolveu as bases para se pensar as cidades contemporâneas e, nesse sentido, Spirn (1995, p. 15) ponderou:

Os problemas urbanos atuais não são diferentes, em essência, daqueles que afetavam a cidades antigas, a não ser quanto ao grau, a toxicidade e a persistência de novos contaminantes, e à extensão da terra que está agora humanizada. Com o crescimento das cidades, essas questões se tornaram mais agudas. Todavia, continuam a ser tratadas como fenômenos isolados, e não como fenômenos interligados resultantes de intervenções humanas corriqueiras, e a ser exacerbada por uma desconsideração pelos processos naturais. A natureza tem sido vista como um embelezamento superficial, como luxo, mais do que como uma força essencial que permeia a cidade. 


\section{PLANEJAMENTO URBANO BRASILEIRO E A PAISAGEM}

Internacionalmente, o campo disciplinar da Arquitetura da Paisagem se constituía no período analisado no primeiro Capítulo, isto é, final do século XIX e a primeira metade do século XX. Nesse período, no Brasil, pode-se relacionar esse campo às permeabilidades do planejamento urbano com a temática ambiental, uma das dimensões da Paisagem. A natureza física e seus atributos foram incorporados ao planejamento urbano de distintas maneiras, inicialmente sob o viés estético, passando por considerações técnicas e, finalmente, sob orientação ambiental-ecológica.

Na primeira parte deste capítulo, a partir de uma perspectiva histórica e seguindo a periodização proposta por Flávio Villaça (1999), procurou-se construir uma trajetória de propostas de planejamento urbano, bem como de seus contextos, tendo vista possíveis contatos com a questão que norteou esse trabalho: planejar com a paisagem. Não se pretendeu fazer um amplo resgate do planejamento urbano brasileiro, escolhendo-se compor esta narrativa a partir do campo em questão.

No primeiro período analisado, compreendido entre o final do século XIX e a década de 1930, o urbanismo nascente deparou-se com problemas de ordem sanitária e com aspectos físicos da paisagem, compreendidos como limitadores ao crescimento e a modernização das cidades. Foram analisados aspectos do Plano de Saneamento para Santos de Saturnino de Brito, que através da tecnologia da época e do aproveitamento dos processos naturais promoveu para a cidade mais que espaços belos e saneados. Apresentam-se também algumas propostas para duas grandes cidades, Rio de Janeiro e São Paulo, nas quais a inserção pontual de espaços verdejados se vinculava ao embelezamento enquanto, as obras viárias e de saneamento começavam a considerar a cidade como um todo.

No segundo período, entre a década de 1930 até o início da década de 1990, a urbanização se intensificava, assim como os problemas dela decorrentes, surgindo a necessidade de planejar a cidade em sua totalidade, tendo a técnica de base científica como protagonista na solução para estes problemas. Este grande intervalo foi dividido em três fases

- Planos de Conjunto (1930-1965), Planos de Desenvolvimento Integrado (1965-1971) e 
Planos sem Mapas (1971-1990) - relacionadas à abordagem do plano diretor, que tinha influência da política, da economia, das legislações, das instituições que o elaboravam. Grosso modo, a caracterização desse período se pautou em estudos detalhados e de grande envergadura, mas com baixa implementação de suas diretrizes. A temática ambiental, inicialmente tratada pelo viés do saneamento, era uma das pautas do plano diretor, constituído a partir de olhares fragmentados sobre a cidade.

O terceiro período, das décadas de 1990 e 2000, foi caracterizado pela reação ao planejamento proposto no segundo período. Para tentar orientar a expansão urbana e democratizar o acesso à terra e à moradia através do mercado imobiliário formal houve a constituição de um corpo legal. A questão ambiental foi incluída nestas regulamentações, sob orientação ecológica, que ganhava visibilidade mundialmente.

Na segunda parte do capítulo, procurou-se compreender quais seriam as lógicas que conduzem as políticas urbanas e as políticas ambientais, particularmente no que se refere aos conflitos entre elas e, quanto à abordagem dos espaços livres. Em seguida buscou-se aproximações entre gestão do território e gestão ambiental, especificamente quanto aos recursos hídricos, que através da Política Nacional de Recursos Hídricos reconheceu a bacia hidrográfica como unidade de planejamento e gestão por seu potencial em articular a questão ambiental e o uso e ocupação do solo.

\subsection{Obras de saneamento e embelezamento e suas consequências}

Assim como ocorreu com as cidades europeias que vivenciaram os problemas decorrentes do processo de urbanização no século XIX, algumas das grandes cidades brasileiras também passaram por problemas semelhantes alguns anos depois. $\mathrm{O}$ incipiente processo de urbanização de cidades como Rio de Janeiro e São Paulo resultou em condições precárias de habitação, epidemias, enchentes recorrentes, problemas de tráfego. 0 período compreendido entre o final do século XIX e 1930 foi marcado pelos denominados Planos de Embelezamento e Melhoramentos, que consistiam em intervenções parciais na cidade sob viés higienista, realizadas principalmente por médicos e engenheiros. Estas intervenções tinham influência europeia, principalmente das realizações de Haussmann em Paris e os 
escritos de Camillo Sitte ${ }^{46}$ sobre Viena, como também do movimento norte-americano City Beautiful ${ }^{47}$, enfatizando questões técnicas e estéticas.

As proposições visavam, por um lado, melhorar as condições de vida da população e, por outro e de forma mais intensa, adequar estas cidades ao novo modo de produção que se conformava em função do desenvolvimento do negócio cafeeiro, em que o meio urbano se tornava preponderante, em detrimento do campo. Foi um momento de transformação das estruturas urbanas herdadas de uma economia colonial e início da formação da cidade moderna, desta forma, a atualização destas estruturas e infraestruturas era imprescindível para o crescimento econômico, especialmente para facilitar a circulação de pessoas e mercadorias. Tal atualização consistia especialmente na solução da questão viária, com o alargamento e retificação de vias e a construção de avenidas para adequação aos novos meios de transporte, como o bonde elétrico. O termo "melhoramentos" designava também projetos e obras de saneamento como a implantação de redes de água e de esgoto; reformas de portos marítimos e fluviais, através da construção de armazéns, diques, dragagem e aterros; construção de praças e parques; elaboração de legislação urbanística.

\section{Plano de Saneamento, Melhoramentos e Expansão para Santos: os canais projetados por Saturnino de Brito}

A partir da segunda metade do século XIX, o porto de Santos adquiriu relevância econômica na exportação do café, propiciada pela construção da ferrovia Santos-Jundiaí. Entre 1886 e 1900 a população da cidade triplicou, acarretando péssimas condições sanitárias e epidemias que passaram a se espalhar para o interior do Estado (ANDRADE, 1992a). Diante desse cenário tornou-se urgente planejar a expansão da cidade e lidar com os problemas de

\footnotetext{
46 Camillo Sitte (1843-1903) foi um arquiteto austríaco, que propôs a construção de cidades conciliando as dimensões técnicas e estéticas. Autor do livro "A construção das cidades segundo seus princípios artísticos" de 1889, em que criticava a monotonia das ruas retas, dos traçados ortogonais e dos blocos uniformes da cidade Oitocentista. Sitte defendia a recuperação dos princípios artísticos para obter efeitos pitorescos e variados, com forte inspiração nos espaços de praça da Itália, bem como defendia a valorização da paisagem e o respeito à topografia, numa visão de cidade oposta à de Haussmann (ANDRADE, 1992b).

${ }^{47}$ Movimento originário no Estados Unidos por ocasião da Feira Mundial em 1893, na qual se destacou o projeto do arquiteto Daniel Burnham para a cidade de Chicago. O Movimento tinha como principais premissas o embelezamento e a monumentalidade através da arquitetura como meio de promover virtudes morais e físicas na população. (BENEVOLO, 2001).
} 
ordem sanitária que começaram a comprometer o funcionamento do porto e a vinda de imigrantes.

Assim, a primeira rede de esgotos foi implantada em 1889, nesse momento com o sistema separador parcial ${ }^{48}$. Outras medidas foram tomadas, como a contratação de projetos de saneamento ao engenheiro Estevam A. Fuertes; a elaboração de um projeto de expansão da cidade em 1896 pela Câmara Municipal, que não foi executado fielmente; formação de comissões sanitárias; a criação do Código de Posturas Santistas; intervenções sobre os cortiços, entre outras medidas (ANDRADE, 1992a).

O engenheiro Francisco Saturnino Rodrigues de Brito ${ }^{49}$ (1864-1929), que havia analisado a questão sanitária de Santos em 1898, foi chamado alguns anos depois para dirigir a Comissão de Saneamento da cidade. Mais que um Plano de Saneamento e Melhoramentos, Brito propôs o planejamento da extensão de Santos, pois entendia a relevância de não se deixar o crescimento urbano ao acaso, além de ser uma forma de diminuir conflitos entre os interesses privados e públicos na expansão da cidade. Deste modo, preconizava os chamados Plano Gerais, nos quais analisou a cidade como um todo, abrangendo questões técnicas e legislativas no sentido de recuperar áreas centrais problemáticas e ordenar a expansão, diferenciando-se das reformas urbanas pontuais realizadas no mesmo período (ANDRADE, 1992a).

O Plano de Saneamento de Brito, elaborado em 1903, indicou uma rede de esgotos com o sistema separador absoluto (separação completa entre o esgoto e as águas pluviais), que já havia sido proposto anteriormente por Fuertes. De acordo com Andrade (1992a) foram construídos entre 1905 e 1914 cerca de 80 km de rede subterrânea de esgoto e 17 km de canais de superfície para as águas pluviais. Neste Plano a cidade foi dividida em bacias de esgotamento, nas quais o sistema funcionava por declividade desde a coleta até as estações elevatórias distritais, e dali seguiam para a usina terminal. Brito adotou processos inovadores

\footnotetext{
${ }^{48}$ Sistema na qual a rede de esgotos recebe os despejos domésticos e as águas pluviais das áreas calçadas e dos telhados (ANDRADE, 1992a).

${ }^{49}$ Francisco Saturnino Rodrigues de Brito, engenheiro formado em 1886 pela Escola Politécnica do Rio de Janeiro, foi responsável pelos planos de diversas cidades brasileiras, entre elas Vitória (1895-1896), Campinas (18961897), Petrópolis (1898), Campos dos Goytacazes (1902-1903), Santos (1905-1910), Recife (1910-1917), João Pessoa (1913), Pelotas (1926-1929). Na época em que foi chamado para Comissão de Saneamento em Santos, ele estava exercendo o cargo de fiscal da City Improvements no Rio de Janeiro. A coleção intitulada "Obras Completas de Saturnino de Brito", composta de 23 volumes, reúne muitos de seus projetos, textos técnicos, relatórios, reflexões e memórias (FARIA, 2015).
} 
para época como a utilização de concreto armado na construção dos canais de drenagem de águas pluviais e a adoção de estações elevatórias distritais.

Para este engenheiro o primeiro passo na elaboração do plano era o esquema de drenagem, em especial o escoamento de águas pluviais, que acompanharia o traçado do sistema viário. Outro aspecto fundamental do planejamento de Brito dizia respeito à adaptação deste traçado à topografia do sítio $^{50}$, assim, no caso de um terreno acidentado o traçado mais adequado seria irregular, para acomodar o escoamento das águas pluviais e aproveitar os efeitos visuais proporcionados por este desenho, revelando a beleza do lugar. Brito discorreu sobre este aspecto no artigo publicado no Jornal do Comércio em 1907:

Os traçados mais belos e racionais de novos arrabaldes e de melhoramentos dos existentes são aqueles que procuram tirar das linhas, das superfícies das construções expostas a vista do transeunte e das circunstâncias naturais todo o partido estético, sem entretanto nos esquecermos de que essas ruas e estes quintais devem ser esgotados das águas pluviais e dos despejos das casas sem nos esquecermos também de que todos os trabalhos públicos devem ser feitos com a precisa economia. (BRITO citado por ANDRADE, 1992b, p. 209).

No caso de um terreno plano, como em Santos, foi adotado o traçado regular, que de acordo com Brito era mais econômico ${ }^{51}$ pelo fato de ser retilíneo e, portanto, facilitar a implantação de outros serviços municipais, além de ser mais conveniente ao policiamento e ao trânsito. No entanto, para quebrar a rigidez do traçado em formato do tabuleiro xadrez, Brito indicou a inserção de avenidas diagonais, melhorando a comunicação entre as diferentes zonas da cidade (BRITO citado por ANDRADE, 1992a).

\footnotetext{
${ }^{50} \mathrm{~A}$ adaptação do traçado urbano ao relevo do terreno pode ser considerada um dos princípios urbanísticos de Brito, fruto de sua experiência com levantamentos planialtimétricos e das influências urbanísticas internacionais como Camillo Sitte (ANDRADE, 1992a; 1992b).

${ }^{51}$ Além das questões técnicas, Brito considerou questões administrativas e econômicas no Plano de Santos, que foram expressas através da racionalidade dos procedimentos aplicados nas operações e obras (ANDRADE, 1992a)
} 


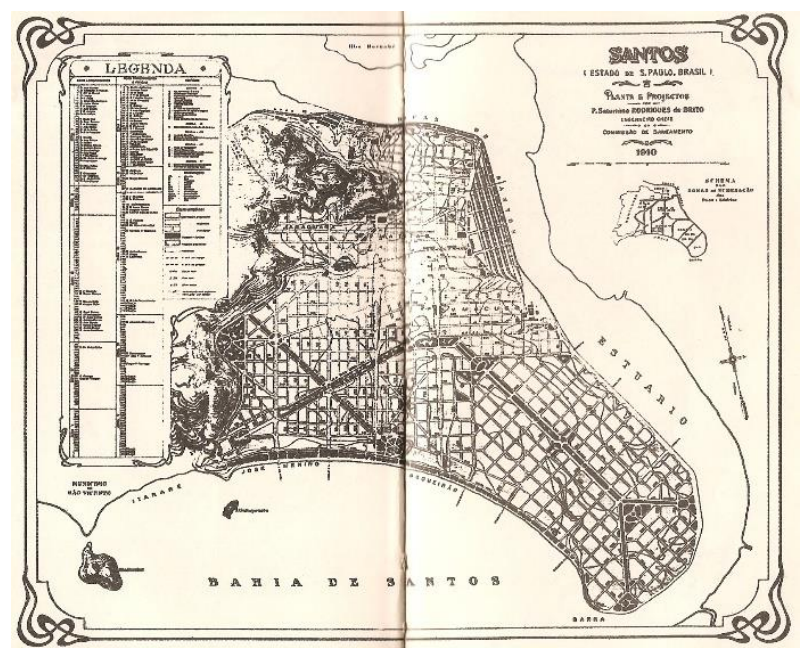

Figura 21: Plano de Expansão da cidade Santos, elaborado por Brito. Fonte: ANDRADE, 1992b, p. 222-223.

Sendo assim, a malha urbana (figura 21) adotada por Brito para Santos, não apresentou um traçado ortogonal rígido, pois além das avenidas diagonais considerou elementos existentes no local, incorporando ruas e edifícios relevantes. Apenas na área de expansão após o canal 4 projetado, então praticamente desocupada, predominou um traçado mais geométrico rígido, deslocado em relação ao traçado do restante da planície (ANDRADE, 1992a). Saturnino de Brito projetou pequenas praças e jardins nas extremidades das avenidas ou nos cruzamentos de ruas e aproveitou tais espaços para implantar equipamentos sanitários, construindo edifícios para abrigar mictórios e estações elevatórias. O engenheiro sanitarista também pensou na inserção de parques públicos, principalmente acompanhando à Avenida Beira-mar, mais uma vez associando as intervenções à instalação de equipamentos de uso público, como campos de esporte e jardins.

Os canais de drenagem pluviais a céu aberto (figura 22) eram controlados por comportas e aproveitavam a ação das marés e, desta forma, promoviam a drenagem da planície e criavam condições para a expansão da cidade. Estes canais também eram navegáveis em alguns trechos, servindo como meio de transporte, facilitando a retirada de materiais dos navios. Configurava-se um novo tipo de espaço público formado por pontes e passadiços, avenidas e calçadas arborizadas que ladeavam os canais e que contribuíram com novas formas de sociabilidade proporcionada pelo passeio nestes locais. Ocorria o contato com a natureza, ainda que através de uma paisagem modificada pela técnica, mas que deixava visíveis seus pulsos naturais. 
A imagem do descontrole das águas, comprometendo o bom funcionamento da cidade e desestabilizando o cotidiano, foi substituída pela ordem das águas canalizadas, pelo rio artificial, com o surgimento de uma maquinaria sanitária que revela a cidade como objeto técnico, mas também estético (ANDRADE, 1992a, p. 142-143).

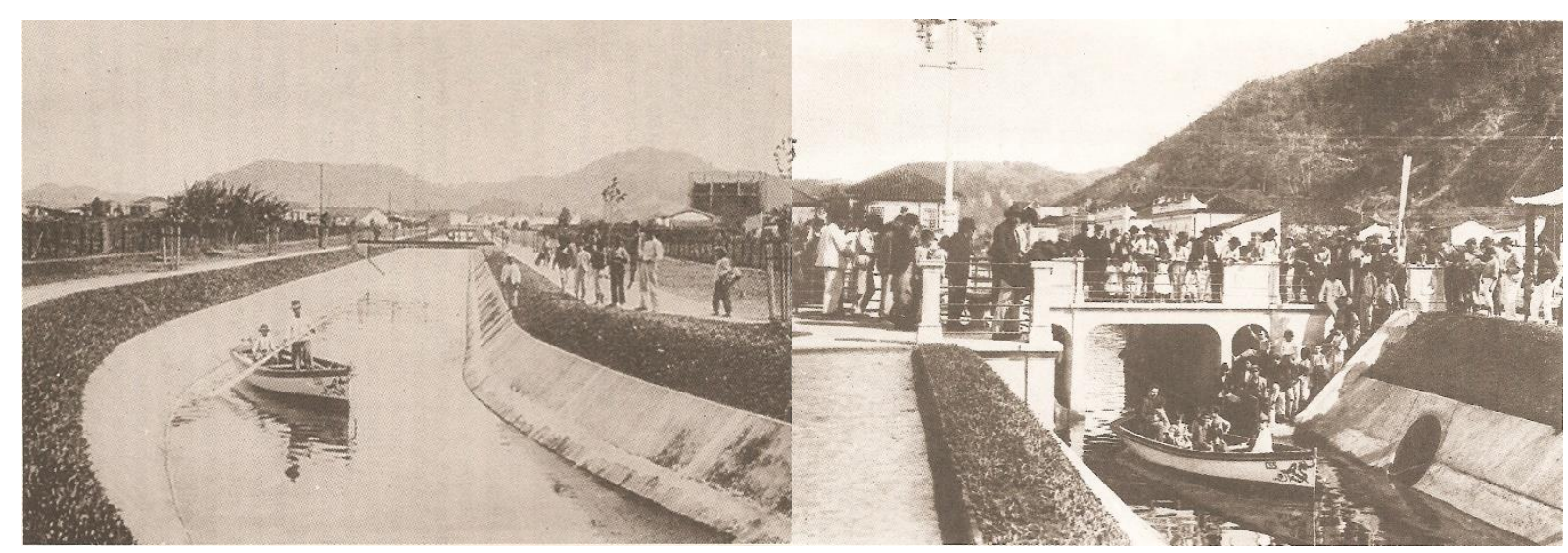

Figura 22: Canais de drenagem pluviais a céu aberto elaborados por Brito para Santos.

Fonte: ANDRADE, 1992b, p. 231 e 234.

O Plano de Brito também promoveu a ampliação dos serviços de abastecimento de água, juntamente com a reforma da rede existente desde 1870 e das instalações sanitárias domiciliares, completando o saneamento da cidade.

Para viabilizar a realização das obras, Brito recomendou alguns instrumentos jurídicos reguladores do desenho urbano e das expropriações de imóveis e terrenos para utilidade pública. Propôs especificações de ordem construtiva que abrangiam dimensionamentos de edificações e ruas (relações entre largura e altura, recuos), questões legais e tributárias, como a contribuição de melhoria.

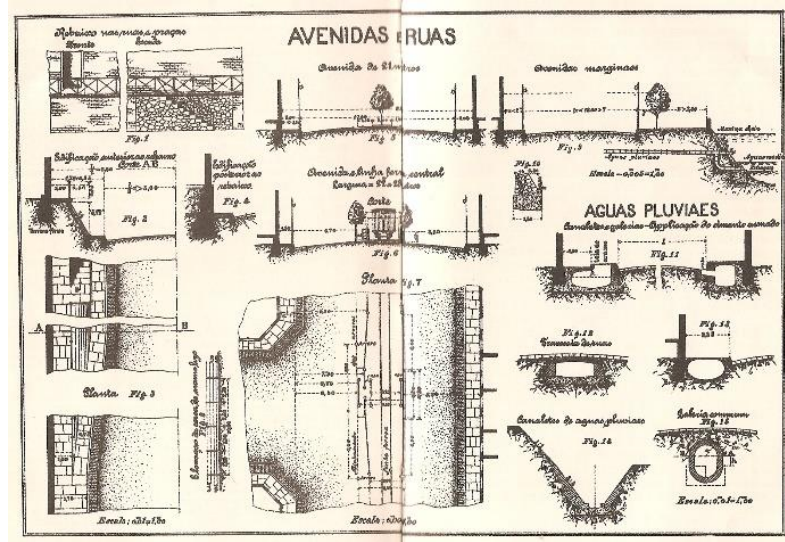

Figura 23: Desenho urbano, elaborados por Brito para Santos.

Fonte: ANDRADE, 1992b, p. 218-219. 
Brito desenvolveu as diferentes escalas do Plano, elaborando desde o projeto da expansão urbana até o desenho dos dispositivos sanitários, passando pelo desenho da rua com todos os detalhamentos de guias, sarjetas, calçadas, bueiros (figura 23). De acordo com Andrade (1992b, p. 232), "o urbanismo de Brito constitui-se como planejamento urbano" por considerar a totalidade da cidade e prever seu crescimento.

Sua obra foi considerada relevante para engenharia sanitária brasileira pela utilização de técnicas apropriadas para a construção de esgotos naquela época, como também pelo aprimoramento de processos e dispositivos empregados no saneamento e drenagem. (ANDRADE 1992b).

\section{Planos de Embelezamento e Melhoramentos para as cidades do Rio de Janeiro e São Paulo}

Como forma de evidenciar o contato entre projetos urbanos e a paisagem, destaca-se as intervenções realizadas entre os anos de 1902 e 1906 na cidade do Rio de Janeiro pelo prefeito e engenheiro Francisco Pereira Passos (1836-1913). A cidade passava por uma crise sanitária, enfrentava recorrentes enchentes e problemas relacionados ao tráfego (REZENDE, 1999). Empreenderam-se obras de saneamento, melhorarias e expansão do sistema viário (por exemplo, a avenida Central, atual avenida Rio Branco), construção de praças, restruturação dos portos, entre outras.

Sob a denominação de "modernização" 52 , as obras no sistema viário acabaram por expulsar a população pobre da área central da cidade, devido a demolição de moradias insalubres e cortiços para abertura e alargamento de ruas e avenidas. A valorização desses espaços remodelados e o aumento do valor de tributos, serviços e aluguéis nessas áreas, também dificultaram a permanência da população de baixa renda. A insuficiência de moradias baratas e salubres no centro da cidade, intensificou a crise habitacional do período, bem como contribuiu para o deslocamento dessa população para os subúrbios ou para os morros próximos da área central (REZENDE, 1999).

\footnotetext{
${ }^{52}$ Embora as obras realizadas tivessem influência do urbanismo europeu e caráter modernizante, no sentido de romper com a estrutura colonial e transformar a cidade na capital do país, ainda não podiam ser consideradas urbanismo moderno, pois este considerava o planejamento da totalidade da cidade, enquanto resolução dos problemas decorrentes da expansão urbana, diferente do caráter pontual e fragmentário das obras de Pereira Passos (ANDRADE, 1991).
} 
O termo "embelezar" tem enorme ressonância no discurso propagandístico da época. Designa mais do que a imposição de novos valores estéticos, a criação de uma nova fisionomia arquitetônica para a cidade. Encobre, por assim dizer múltiplas "estratégias". A erradicação da população trabalhadora que residia na área central; [...] a mudança de função do centro, atendendo - num plano mais imediato - aos interesses especulativos que cobiçavam essa área altamente valorizada e - num plano mais geral - as exigências da acumulação e circulação do capital comercial e financeiro; ações ideológicas ligadas ao "desfrute" das camadas privilegiadas; razões políticas decorrentes de exigência exigências específicas do Estado republicano em relação àquela cidade que era sede do poder político nacional. (Benchimol citado por Villaça, 1999, p. 193).

Foram realizadas grandes obras como a reestruturação dos portos, que incluíam o aterramento de alagadiços e mangues utilizando terra proveniente do desmonte dos morros, intervenções que já ocorriam no governo anterior (LEME, 1999). As transformações na cidade incluíram ainda a inserção de espaços livres como o Passeio Público, a Praça XV de Novembro, a Praça São Salvador, a Praça Tiradentes, o Largo da Lapa etc.

Posteriormente (1926-1930), um novo projeto urbanístico para a cidade do Rio de Janeiro foi desenvolvido pelo urbanista francês Alfred Agache (1875-1959) a convite do prefeito Antônio Prado Júnior. De acordo com Leme (1999), ele utilizou uma metodologia típica dos planos diretores da época, na qual eram identificados os problemas e defasagens em relação ao modelo de cidade proposto pelo urbanista. Um dos enfoques era o sistema viário, que estruturava o plano e tinha a função de promover a circulação eficiente entre os diversos bairros, propondo uma rede de ferrovias e de metrô como forma de melhorar o congestionamento da cidade. O saneamento era questão chave do Plano e contemplava a totalidade da cidade através do desenvolvimento de estudos relativos ao abastecimento da água, à coleta de esgotos, ao combate às inundações e à limpeza pública. A questão do embelezamento ainda estava presente ao propor transformar a cidade numa capital monumental, e estava associada às áreas verdes naturais e à paisagem construída, através da implantação de grandes avenidas arborizadas e jardins.

Em São Paulo, em 1911, o engenheiro e diretor da Seção de Obras Municipais, Victor Freire (1869-1951) juntamente com o arquiteto francês Joseph-Antoine Bouvard (1840-1920), convidado pela Prefeitura, elaboraram um plano de melhoramentos para a área central, que considerava a topografia acidentada e previa a criação de áreas verdes. Eles criticavam a remodelação urbana com referência nos bulevares retilíneos, pois julgavam esta transposição 
descontextualizada da realidade de São Paulo, que apresenta relevo acidentado. Deste modo, eles defendiam os pressupostos do arquiteto austríaco Camilo Sitte em relação à topografia, valorização da paisagem e, produção de efeitos pitorescos (ACKEL; CAMPOS, 2002).

Para descongestionar o centro histórico, o Plano Bouvard adotou uma estrutura viária radial e perimetral a partir dele, atentando para o relevo natural. Bouvard acreditava na conservação e criação de espaços livres ajardinados, fundamentais para a salubridade da cidade, considerando-os "centros de vegetação, de reservatórios de ar" (BOUVARD citado por ACKEL; CAMPOS, 2002, p. 41). O plano envolvia o projeto de dois parques circundando a colina histórica, um no Vale do Anhangabaú e outro na várzea do rio Tamanduateí, futuro Parque Dom Pedro II.

No vale do Anhangabaú, o projeto articulava as duas encostas (de um lado a colina histórica e de outro os novos bairros) por meio de ajardinamento, passeios para pedestres e uma via, integrando o paisagismo aos edifícios, que agora se voltavam para o vale. As obras de alargamento das ruas do entorno e as novas edificações, destacando-se a rua Líbero Badaró, os Palacetes Prates e o Teatro Municipal, deram mais visibilidade ao local, que posteriormente seriam o cartão de visitas da cidade, representando as transformações políticas e econômicas daquele período e demonstrando claramente uma influência urbanística europeia (LEME, 1999).

Para viabilizar a implantação do Plano, Freire e Bouvard previram a conciliação com os interesses imobiliários, promovendo a integração dos futuros edifícios (Palacetes Prates, construídos no terreno do conde de Prates) às novas áreas verdes do Anhangabaú. No caso da várzea do rio Tamanduateí, a opção era a alienação de parte da área à particulares, o que geraria recursos financeiros para a implantação do Parque (ACKEL; CAMPOS, 2002).

Um segundo grupo de intervenções do Plano Bouvard, a implantação de um Centro Cívico na área no entorno da Sé, previa a construção de edifícios públicos (nova Catedral de São Paulo, Palácio da Justiça, Paço Municipal, Congresso Estadual) articulados por uma série de espaços livres e áreas verdes, projetados segundo questões estético-paisagísticas, de forma a valorizar estes edifícios e proporcionar um efeito de grandiosidade ao conjunto da obra (ACKEL; CAMPOS, 2002). 
De acordo com Ackel e Campos (2002), as intervenções realizadas em São Paulo até 1930 visavam transformar a cidade na "capital do café", fortalecendo-a como centro político, econômico e administrativo, através de propostas destinadas fundamentalmente aos interesses das elites, que não contemplavam a totalidade do espaço urbano com exceção das propostas ao sistema viário. Configuravam-se alguns espaços de qualidade em que havia harmonia entre arquitetura, paisagem e topografia, enquanto os espaços menos privilegiados eram relegados à moradia da população trabalhadora e implantação de indústrias.

As adequações do sistema viário paulistano foram planejadas pelo engenheiro civil e arquiteto Francisco Prestes Maia (1896-1965) através do Plano de Avenidas (1930). Da mesma maneira que os outros planos urbanísticos deste período, a ideia central era estruturar a cidade para seu crescimento, especialmente com base na circulação, e com foco no transporte rodoviário e no automóvel.

O Plano de Avenidas consistia em um arranjo viário radial-perimetral, composto por um sistema de avenidas que aliviaria o tráfego da área central da cidade, sendo a primeira perimetral no entorno do centro - o perímetro de irradiação. Haveria uma perimetral, denominada parkways, que contornaria a cidade e articularia parques existentes e novos; semelhante a uma proposta elaborada anteriormente por Barry Parker em 1919, porém sem a função de conter a expansão urbana como pretendia Parker (LEME, 1999), premissa vinculada ao modelo Cidade Jardim de Howard. As avenidas que formariam essa perimetral seriam marginais aos rios Tietê e Pinheiros e associariam espaços livres, instalações esportivas, uma nova estação férrea e indústrias. De acordo com Leme (1999), no Plano de Prestes Maia, a prioridade era aumentar a área urbanizada nas várzeas, propondo a canalização ${ }^{53}$ dos rios e, abdicando de projetos anteriores de traçado pinturesco como os promovidos por Saturnino de Brito entre 1924 e 1925, bem como da possibilidade de navegação do rio. O Plano de Avenidas foi implantado ao longo dos anos, de forma fragmentada devido às descontinuidades políticas, a primeira perimetral foi concluída apenas na década de 1940, durante o primeiro governo do próprio Prestes Maia (1938-1945), sendo a terceira perimetral fechada nos anos 1990 (SOMEK; CAMPOS, 2002).

\footnotetext{
${ }^{53}$ A canalização do rio Tietê já havia sido objeto de outras propostas no século XIX por conta das inundações em suas várzeas.
} 
Tanto no Rio de Janeiro como em São Paulo, a remodelação da cidade indicou a necessidade de legislação urbanística e edilícia para viabilizar as desapropriações e orientar as novas construções quanto à salubridade, através de normas de parcelamento do solo, códigos de posturas e código de obras. Tais normas tratavam de recuos, gabaritos, alinhamentos, área mínima das edificações, pé-direito, e podiam também estabelecer critérios de homogeneização estética nas fachadas das novas edificações nas áreas de intervenção (LEME, 1999), dimensionamentos e desenho das vias, e restrições construtivas.

As obras que forjaram a nova fisionomia da cidade, também modificaram drasticamente o ambiente e a fisionomia de sua paisagem - arrasamento de morros, aterramento de mangues e terrenos alagadiços, canalização de rios e implantação de avenidas marginais etc. - intervieram intensamente em ecossistemas e construíram o conflito com o ambiente natural.

Nesse período, a paisagem, quando considerada, era vista apenas sob aspecto estético, tal qual a inserção de espaços verdes na forma de praças, jardins, que também eram vinculados ao sistema viário. Ainda não havia a preocupação ambiental e ecológica. Muito menos se atentava para os benefícios sociais inerentes ao aproveitamento das forças da natureza, embora essa questão estivesse presente no trabalho e nos escritos do pioneiro do campo disciplinar da Arquitetura da Paisagem, Frederick Law Olmsted. A constituição desses espaços verdejados se inseria antes na lógica capitalista da cidade burguesa, que agregava às obras valor imobiliário, estando, portanto, voltada aos interesses das classes sociais economicamente dominantes.

A internacionalização da cultura urbanística no final do século XIX e início do século XX ganhou impulso pela circulação de ideias por meio de congressos, fóruns, revistas e associações de urbanismo, com as quais os profissionais brasileiros mantiveram contato. Os modelos e práticas difundidas internacionalmente foram aplicados no Brasil, muitas vezes desconsiderando o contexto físico na qual foram implantadas, com exceção das obras de Saturnino de Brito. A respeito disso, Schvarsberg (2011) apontou:

A haussmanização como alguns denominaram a transposição acrítica de um ideário aplicado em contextos distintos foi quase uma panaceia - receita aviada para cura de todos males urbanos: sejam cidades litorâneas, interioranas ou no planalto, cidades com sítios de topografia plana ou acidentada, com traçado urbanístico em malha ortogonal, radioconcêntrica 
ou orgânica. Mas via de regra calcada em uma prática de apropriação simplista do projeto francês, enfatizando de forma fundamental a abertura de uma ou mais avenidas largas e extensas; e, sempre que possível, com a clássica convergência para uma rotonda, uma praça ao estilo da parisiense Place de L'Etoile. São bem difundidos os estudos que fazem uma leitura crítica arguta revelando o caráter segregador e excludente oculto na aparência modernizante dessas intervenções. (SCHVARSBERG, 2011, p.18).

A partir de 1930, entram em declínio os Planos de Embelezamento e Melhoramentos e começam a ser elaborados "Planos de Conjunto", assim denominados por envolver questões relativas à totalidade da cidade e sua expansão, bem como por abordar vários problemas urbanos. Os planos de Agache pra o Rio de Janeiro e de Prestes Maia para São Paulo situamse no momento de transição entre esses dois modelos, pois ainda apresentam um apelo ao embelezamento, mas já começam a olhar a cidade como um todo, por exemplo ao tratar de questões de circulação. Ressalvas para os planos de saneamento, particularmente os elaborados por Saturnino de Brito, que já no final do século XIX apresentavam a visão de totalidade da cidade existente, integrada à sua expansão (LEME, 1999).

\subsection{A visão da cidade como totalidade: planos tecnicistas como solução dos problemas urbanos}

Entre os anos 1930 e 1990 foram elaborados os chamados planos tecnicistas que, de acordo com Villaça (1999), fortaleceram a crença de que a ciência, a racionalidade, a técnica seriam a solução para os problemas urbanos resultantes de seu intenso crescimento. $O$ autor apontou para passagem da "cidade bela" para a "cidade eficiente", momento em que o funcionamento urbano adquiriu maior importância que seus atributos estéticos, sendo privilegiadas as obras de infraestrutura, principalmente aquelas relacionadas à circulação.

No bojo das Reformas de Modernização do Estado, nos primeiros anos do período conhecido como "Era Vargas" (1930 a 1945), ocorreu a centralização política e administrativa do Estado. Em âmbito municipal, além das funções de organização administrativa, o governo assumiu funções de planejamento urbano. Desta forma, foram criados setores de urbanismo dentro das prefeituras, muitos dos quais sob influência do urbanismo norte-americano ${ }^{54}$.

\footnotetext{
${ }^{54}$ Modelo de administração pública conhecido como Scientific Management School, que "se caracteriza por privilegiar soluções técnicas para problemas administrativos e por desvincular a administração dos conflitos que ocorrem na arena política" e pressupõe uma organização hierárquica sob uma coordenação como forma de atingir os objetivos de eficiência, economia e racionalidade (FELDMAN, 2005, p. 47-48).
} 
Nos anos 1940 começou ser utilizado o termo "planejamento urbano", designando a ampliação do escopo do "urbanismo" (VILLAÇA, 1999) para que abrangesse a totalidade da cidade e todos os setores da vida urbana, assim os planos deste primeiro subperíodo (1930 a 1965) foram denominados "Planos de Conjunto". Desta forma, o planejamento urbano pressupunha equipes ${ }^{55}$ compostas por médicos, engenheiros, advogados, sociólogos, que diagnosticavam os problemas urbanos a fim de propor medidas que integrariam os aspectos econômicos, físicos, sociais e políticos. A execução destas medidas seria coordenada e acompanhada por um órgão central e deveria ter revisões contínuas.

Todas as divisões do departamento de urbanismo de uma prefeitura, juntamente com outros setores da administração municipal e estadual deveriam envolver-se no processo de elaboração do plano, constituído das seguintes etapas: "a pesquisa, a elaboração de diretrizes, a elaboração de regulamentação urbanística, o detalhamento, a divulgação" (FELDMAN, 2005, p. 278). No entanto, apesar de associar diversos saberes e abranger a cidade como um todo, tais planos ainda não compreendiam os processos naturais, nem consideravam questões estético-culturais e tampouco entendiam a paisagem como integradora de todas essas questões.

Feldman (2001, p. 39) ponderou sobre a consolidação de uma visão legalista do urbanismo brasileiro a partir da década de 1940, indicando que "ao processo de declínio da importância do plano como instrumento de intervenção no espaço urbano corresponde a ascensão da legislação como instrumento por excelência do planejamento". Na cidade de São Paulo a vinculação do plano ao zoneamento, que se tornaria o principal instrumento de planejamento urbano, se traduziu numa forma de valorizar determinadas áreas da cidade de acordo com os interesses das elites e do mercado imobiliário. Somaram-se à legislação de zoneamento, os Códigos de Obras e de Edificações, as leis de Parcelamento e Uso e Ocupação do Solo, que por determinarem parâmetros construtivos, acabaram por estipular a configuração da paisagem urbana.

\footnotetext{
55 Sobre equipes multidisciplinares no planejamento urbano, Feldman (2005) colocou: "O urbanista deve conhecer muitas disciplinas que se referem aos múltiplos aspectos da vida urbana, e nenhum indivíduo consegue alcançar esta universalidade de conhecimentos práticos, doutrinários, técnicos. Por isso, a cooperação é um imperativo é uma condição da disciplina urbanística. Exige muito estudo e dedicação, e deve ser realizado por equipes de técnicos especializados nas várias áreas, e coordenado por homens de maior integração cultural" (FELDMAN, 2005, p. 88).
} 
A partir da década de 1950 os planos diretores começaram a ser elaborados por instituições autônomas, ou seja, externas à administração pública. Muitas destas instituições que atuavam nos municípios através da assistência técnica e parcerias, surgiram entre as décadas de 1940 e 1960, entre elas a Sociedade de Artes Gráficas e Mecanográficas Aplicadas aos Complexos Sociais (SAGMACS) em 1947, o Instituto Brasileiro de Administração Municipal (IBAM) em 1952 e o Centro de Estudos e Pesquisas Urbanísticas (CPEU) em 1957, este último criado dentro da Faculdade de Arquitetura e Urbanismo da Universidade de São Paulo ${ }^{56}$. Estas instituições, que também eram formadas por equipes multidisciplinares, mobilizaram diferentes concepções e práticas urbanísticas e contribuíram na legitimação da atividade de planejamento através da difusão da ideia de plano abrangendo a cidade como um todo, bem como através da qualificação do profissional urbanista para atuar neste campo (FELDMAN, 2005).

Um exemplo de atuação desse tipo de instituição foi o trabalho desenvolvido pelo CPEU por meio de pesquisas para orientação da execução de Planos Diretores, que compreendiam um extenso levantamento do território analisado, incluindo informações sobre os elementos naturais e os elementos humanos ${ }^{57}$ e abarcava diversos aspectos relacionados à cidade em sua totalidade. Os Planos Diretores Municipais elaborados por este Centro compreendiam sistemas gerais, isto é, Sistema de vias principais; Zoneamento (áreas residenciais, comerciais, industriais e recreativas); Espaços Livres ou Sistema de Recreio. Este último sistema deveria atender diferentes demandas da população e, portanto, tinha a seguinte composição:

1) Área de recreio ativo para crianças de idade pré-escolar, abaixo de cinco anos.

2) Área de recreio ativo para crianças de idade escolar.

3) Área de recreio ativo para rapazes e adultos.

\footnotetext{
${ }^{56}$ O CPEU foi criado pelo Prof. Anhaia Mello, que teve seu trabalho influenciado pelo ideário da Cidade Jardim de Howard (FELDMAN, 2005) e dirigiu a instituição até 1961.

57 Os elementos naturais envolviam dados geográficos, geológicos, climatológicos. Os elementos humanos abrangiam: histórico da origem do local, incluindo dados populacionais; atividades da população (localização das indústrias, do comércio); comunicações (transportes); funções da aglomeração (área de influência das atividades); serviços públicos; ensino e saúde; residências (estatísticas, localização e características); espaços livres verdes (áreas públicas ou de uso público, parques regionais e avenida parques); monumentos históricos; vida comunal (áreas de influência dos serviços, comércio e parques), área urbana (perímetro urbano); legislação e finanças públicas (BIRKHOLZ, 1964).
} 
4) Parques setoriais, ou de bairro para recreio de todas as idades. (Centro de Pesquisa e Estudos Urbanísticos - Boletim no 8, citado por BIRKHOLZ, 1964, p.44-45).

\section{Inserção da temática ambiental no plano diretor}

Monte-Mór (2008) indicou que até 1964 o governo estatal entendia o planejamento do espaço urbano como "artigo de luxo", reservado aos grandes projetos políticos, restringindo sua atuação à questão habitacional. Porém, notava-se o aparecimento de problemas urbanos-ambientais e sociais nas cidades e principalmente nas metrópoles brasileiras, o que sugeria uma atuação efetiva por parte do Estado.

Em 1964, o país já se aproximava da sua "maioridade urbana" e o crescimento metropolitano era inegável e intenso em todas as suas dimensões - da concentração industrial às favelas. $O$ urbanismo não poderia continuar a ser um privilégio reservado aos espaços nobres. As cidades brasileiras e, principalmente, as metrópoles passaram a se apresentar como focos de problemas e surgiu a necessidade de instrumentos de controle social e econômico, pois, ao mesmo tempo, as aglomerações urbanas se tornavam atores principais do modelo político-econômico que se intentava implantar (MONTE-MÓR, 2008, p. 45).

Em 1963, o Instituto dos Arquitetos do Brasil (IAB) organizou o Seminário de Habitação e Reforma Urbana (SHRU) para discutir os problemas urbanos e habitacionais. O Seminário resultou num documento contendo as bases para enfrentar estes problemas e implementar a chamada reforma urbana. No entanto, as propostas com caráter progressista discutidas no SHRU foram abafadas pelo regime militar, sendo incorporadas somente as recomendações que não entravam em choque com as disposições deste governo.

O processo de institucionalização do planejamento urbano como função do governo, intensificou-se em 1964 com a criação do Serviço Federal de Habitação e Urbanismo (SERFHAU), órgão administrativo do governo federal que inicialmente tinha a função de elaborar e coordenar a política urbana nacional. Dentro das atribuições deste órgão estavam a elaboração de normas e a assistência técnica aos municípios para auxiliar a produção e implantação dos Planos Diretores Integrados, sendo que esta função que se cristalizou nos anos 1970 como seu objetivo principal. Neste período, as discussões sobre o plano diretor ocorreram, portanto, no momento político da ditadura militar, em que Estado centralizou poderes, podendo intervir nos municípios. 
No ano de 1964, também foi criado o Banco Nacional de Habitação (BNH), órgão responsável por orientar, disciplinar, dar assistência financeira e controlar o Sistema Financeiro da Habitação (SFH), também instituído em 1964. O repasse de recursos para as cidades era determinado pela lei orgânica dos municípios e estava condicionado à criação de estruturas administrativas para elaboração do Plano Diretor Integrado. Foi nessa época que foram desenvolvidos os planos diretores para cidades médias e grandes e, como muitas prefeituras não tinham técnicos capacitados em seus quadros de funcionários, o Estado disponibilizou órgãos de assistência técnica como o Centro de Estudos e Pesquisas de Administração Municipal (CEPAM) (1967) e o Instituto Brasileiro de Administração Municipal (IBAM) (1952) (FELDMAN, 2005).

Os planos elaborados fora da administração pública se diferenciavam dos planos anteriores por trazerem uma infinidade de recomendações que não se vinculavam às leis, dificultando sua execução. Os órgãos públicos se multiplicavam e se especializavam ao ponto de impossibilitar uma ação integrada e coordenada dos diversos setores e esferas da administração pública, atravancando ainda mais a efetivação das propostas (VILLAÇA, 1999). Estes planos tornaram-se extremamente abrangentes, incorporando para além de questões urbanísticas, diversos aspectos relacionados à cidade, tais como: "educação, saúde, habitação, bem-estar social, recreação, cultura, esportes, poluição do ar, gás, limpeza pública, comunicações, cemitérios, energia elétrica, iluminação pública, segurança pública, abastecimento, finanças e administração pública" (VILLAÇA, 1999, p. 215-216). Tais planos contemplavam problemas que não interessavam às elites, o que de acordo com Villaça (1999), contribuía para que não fossem executados. Para este autor, o período compreendido entre 1965 e 1971 corresponde ao "planejamento-discurso", assim denominado pelo crescente distanciamento entre os planos e propostas e as possibilidades de serem implementados por parte de uma administração pública.

Segundo Costa (2008), o envolvimento de equipes de profissionais de diferentes áreas na elaboração dos chamados Planos de Desenvolvimento Integrado não sustentava essa integração. Os planos converteram-se em olhares fragmentados sobre a realidade e resultaram em amplos diagnósticos refletidos em diretrizes de uso, ocupação e parcelamento do solo e outras legislações. Esta visão fragmentada relaciona-se com o planejamento 
setorizado, que entende o território como um conjunto de setores, isso é, setor de habitação, setor de transporte, setor de saúde etc. Na lógica de setorização, encontrava-se inserida a temática ambiental, que na década de 1970 começou a se fortalecer mundialmente. No Brasil, a pauta ambiental foi incorporada aos planos na forma de um apanhado de características naturais determinantes para o desenvolvimento econômico, porém descolada das demais políticas setoriais.

Olhar do geógrafo comparecia, juntamente com o do historiador na caracterização geral do município ou região, elemento importante para a realização do diagnóstico. Características do quadro natural eram descritas com vistas reconhecer os condicionantes da ocupação territorial, bem como potencialidades de desenvolvimento econômico e do futuro ordenamento espacial a ser proposto. Naquela perspectiva, o ambiente natural comparece mais como um conjunto de atributos dados do processo de produção do espaço do que como elemento em torno do qual se configurassem conflitos quanto à apropriação ou controle destes bens ou recursos. Nesse sentido pode-se dizer que havia ainda uma despolitização da análise, das práticas e representações do ambiente natural (COSTA, 2008, p. 83).

A temática ambiental foi reconhecida como uma das políticas setoriais associadas às áreas de saneamento e "meio ambiente", que envolviam a identificação e proteção de "áreas verdes" e de preservação e aspectos relacionados à poluição, especialmente do ar, e à localização de equipamentos que demandam condições ambientais especiais (matadouros, cemitérios, depósito de lixo etc.). O setor de saneamento compreendia principalmente os serviços de água e esgotos, rede de drenagem de águas pluviais e serviços de coleta e disposição final do lixo. Costa (2008) criticou a falta de articulação dos setores que tratavam da temática ambiental, bem como falta de articulação entre as esferas do governo envolvidas na implementação dos serviços relacionados.

De acordo com Monte-Mór (2008), o modelo de planejamento adotado pelo SERFHAU e pelo $\mathrm{BNH}$ na verdade agravou ${ }^{58}$ os problemas críticos deste período: a especulação

58 O planejamento desenvolvido pelo SERFHAU trouxe experiências positivas, como a sistematização do conhecimento dos problemas brasileiros, a elaboração dos diagnósticos e proposições, além da construção de muitas moradias; contudo, a política habitacional instaurada no regime militar visava angariar apoio político entre as massas populares e criar uma política permanente de financiamento capaz de estruturar o setor da construção civil nos moldes capitalistas, deste modo, combatendo as ideias comunistas e progressistas, se afastando dos ideais da Reforma Urbana, considerada antagônicas ao regime. Esta política habitacional baseada no acesso à propriedade privada por meios legais, desconsiderou a demanda de grande parte dos trabalhadores informais por programas flexíveis e por subsídios destinados à população de baixa renda (BONDUKI, 2014). Monte-Mór (2008) e Bonduki (2014) elaboraram detalhadamente essa crítica em seus textos, mas neste trabalho é importante saber as consequências deste planejamento para a configuração da paisagem da cidade. 
imobiliária e o processo de expansão periférica das cidades. Uma vez que o BNH estabeleceu no orçamento dos empreendimentos uma porcentagem máxima para o valor da terra, uma vez que o objetivo era priorizar os recursos para a construção das habitações, os conjuntos habitacionais foram implantados onde a terra era mais barata, isto é, na área rural e nas franjas da área urbanizada (BONDUKI, 2014). Ao mesmo tempo, as áreas centrais das grandes cidades adensavam-se e verticalizavam-se com o estímulo financeiro à construção particular das classes médias e altas, acentuando a segregação socioespacial e a supervalorização de imóveis urbanos (MONTE-MÓR, 2008). Segundo Bonduki (2014), estes conjuntos habitacionais financiados pelo $\mathrm{BNH}$ apresentavam projetos padronizados e de grande dimensão, que desconsideravam o meio físico e a identidade cultural, ou seja, o contexto urbano-ambiental nos quais eram implantados. Este tipo de empreendimento teve implicações tanto de caráter ambiental quanto urbano e social. Nesse sentido, a construção destes bairros periféricos e desarticulados da área urbana consolidada e servida de boa infraestrutura (transporte, equipamentos públicos, serviços e comércio) acabou configurando os denominados "bairros dormitórios", bem como contribuindo para o surgimento de vazios urbanos.

Ainda de acordo com Bonduki (2014), a concepção urbanística desse período desconsiderava a cidade real, ou seja, aquela construída à margem da legalidade e que crescia num ritmo acelerado. Devido à inexistência de alternativas de acesso à terra urbanizada e à moradia com preços compatíveis com sua renda, as classes populares passaram a ocupar locais impróprios, como áreas ambientalmente vulneráveis (várzeas, encostas, mangues), ou áreas menos valorizadas para o mercado imobiliário formal, bem como áreas com pouca infraestrutura urbana.

Neste processo, os proprietários de glebas, loteadores e corretores desempenhavam o papel de ofertarem os lotes a um custo compatível à capacidade de pagamento dos trabalhadores via prestações. Quanto menos infraestruturado e mais distante, menor o preço. O papel do Estado era a permissividade, à revelia de qualquer controle administrativo e urbanístico. O papel do trabalhador era resolver seu problema habitacional dentro desta oferta, que a combinação entre Estado e mercado oferecia. Fechava-se então uma aliança entre os agentes produtores de loteamentos, Estado e classe trabalhadora, num pacto que iria consagrar a solução loteamento periférico clandestino, com autoconstrução como a forma de acesso à moradia popular no Brasil, cristalizada e perpetuada até os dias atuais (LEONELLI, 2010, p. 80). 
Travassos e Schult (2013) apontaram que a partir da década de 1970 houve a ampliação dos problemas socioambientais decorrentes da crescente ocupação das várzeas, não apenas por habitações de baixa renda, como pela construção de avenidas de fundo de vale e canalização de córregos, frutos do modelo hegemônico de urbanização da época.

Avançando nessa narrativa, e ainda dentro da subdivisão estabelecida por Villaça (1999), os anos seguintes, compreendidos entre 1971 e 1992, foram marcados pelos "Planos sem Mapas", assim denominados pela sua simplicidade, apresentando apenas "objetivos, políticas e diretrizes", sem contar com extensos diagnósticos técnicos e uma infinidade de mapas como se via nos planos dos anos anteriores. De acordo com o autor, tais planos eram elaborados pelos próprios técnicos municipais e, por mais bem-intencionados que fossem seus dispositivos, constituíam apenas generalidades, envolvendo temáticas diversas, muitas vezes externas à competência municipal. As diretrizes deveriam ser detalhadas posteriormente, porém isso não acontecia. Villaça (1999) assinalou que esta era uma estratégia das classes dominantes para ocultar conflitos.

Os movimentos populares começaram a se fortalecer na década de 1970, retomando as pautas do Seminário de Habitação e da Reforma Urbana de 1963. Numa reação aos problemas urbanos vivenciados pelas classes populares nas últimas décadas e ocultados pelos planos diretores, estes movimentos reivindicavam políticas públicas efetivas.

Não reivindicaram planos diretores, pois estavam conscientes de que eles vinham servindo apenas para tentar perpetuar a inanição do Estado. As políticas públicas reais nas esferas imobiliária e fundiária não passava por plano diretores, mas vinham se manifestando principalmente pelas políticas habitacionais e da legislação urbanística - especialmente as de loteamentos e zoneamento; essa legislação é seguida nos bairros mais ricos das nossas cidades, mas no restante coloca a maioria na clandestinidade (VILLAÇA, 1999, p. 232).

Bonduki (2014) apontou que o regime militar, com seu caráter conservador, dificultou a adoção de medidas mais ousadas na política urbana, como o atendimento das propostas do Seminário de Habitação e Reforma Urbana (SHRU). Apesar disso, foram desenvolvidos estudos sobre instrumentos urbanísticos avançados, tais como o imposto progressivo sobre terrenos ociosos, o solo criado e o direito de preempção, que chegaram a constar em projetos de lei e, no entanto, naquele momento, sofreram forte oposição do setor imobiliário e da construção civil. No período ocorreu a aprovação da Lei Federal no 6.776/1979 que regulamentou o 
parcelamento do solo, numa tentativa de conter os loteamentos clandestinos e garantir um padrão mínimo de urbanização.

\subsection{Constituição de um corpo legal para ordenar a expansão urbana}

\section{Lei Federal no 6.766/1979}

A partir da aprovação da Lei Federal no 6.766 de dezembro de 1979, que “Dispõe sobre o Parcelamento do Solo Urbano e dá outras Providências", os munícipios encontraram um respaldo para o controle da implantação dos loteamentos e para o combate à clandestinidade. Apesar de sua abrangência nacional na regulamentação do parcelamento do solo urbano, foi prevista, de forma complementar, a autonomia da instância municipal para adequação da lei às características regionais e locais.

Foram quatro décadas de debates e propostas de projetos de lei até que houvesse essa normatização. As discussões tiveram início a partir da promulgação de um primeiro decretolei federal a tratar da questão em 1937, embora as capitais já legislassem sobre aberturas de vias, divisões de lotes, procedimentos administrativos e regras urbanísticas sobre as dimensões do lote mínimo, da exigência de infraestrutura e da definição de áreas não parceláveis e de áreas públicas (LEONELLI, 2010). Não existia, porém, um instrumento legal capaz de conter o processo de especulação imobiliária.

O texto referente à lei iniciava-se pela definição de duas tipologias de parcelamento do solo, resumidamente: o loteamento - subdivisão de gleba em lotes com abertura de novas vias de circulação; e o desmembramento - subdivisão de gleba em lotes com aproveitamento do sistema viário existente. Em seguida, estipulava-se que o parcelamento urbano seria admitido nas zonas urbanas ou de expansão urbana e que ao município caberia o delineamento destas zonas. Vale destacar o parágrafo que esclarecia em quais situações não era permitido o parcelamento devido às características do meio físico, entendidas como limitadoras à urbanização no sentido de se evitar prejuízos humanos e materiais, bem como preservar o meio ambiente.

I - em terrenos alagadiços e sujeitos a inundações, antes de tomadas as providências para assegurar o escoamento das águas;

II - em terrenos que tenham sido aterrados com material nocivo à saúde pública, sem que sejam previamente saneados; 
III - em terrenos com declividade igual ou superior a $30 \%$ (trinta por cento), salvo se atendidas exigências específicas das autoridades competentes;

IV - em terrenos onde as condições geológicas não aconselham a edificação; $\mathrm{V}$ - em áreas de preservação ecológica ou naquelas onde a poluição impeça condições sanitárias suportáveis, até a sua correção (BRASIL, 1979).

Havia um Capítulo referente aos requisitos urbanísticos mínimos para um loteamento, o que foi considerado um grande avanço por garantir um padrão para o habitar. Deste modo, o loteador deveria atender aos requisitos mínimos, dos quais cita-se o lote com área mínima de $125 \mathrm{~m}^{2}$ e a destinação de uma parcela de áreas públicas, na proporção da densidade de ocupação prevista para a gleba. Estas áreas seriam reservadas para o sistema de circulação, para a implantação de equipamento urbano e comunitário ${ }^{59}$ e para os espaços livres de uso público, que deveriam corresponder ao mínimo de 35\% do total a ser parcelado. 0 poder municipal seria responsável pela emissão de diretrizes indicativas do uso do solo, do traçado básico do sistema viário, da localização aproximada dos terrenos destinados aos espaços livres e aos equipamentos urbanos e comunitários. Outro requisito importante consistia na reserva ${ }^{60}$ de uma faixa non aedificandi de 15 metros de cada lado "ao longo das águas correntes e dormentes, e das faixas de domínio público das rodovias, ferrovias e dutos" (BRASIL, 1979). Este requisito foi contestado, pois não dialogava com o Código Florestal

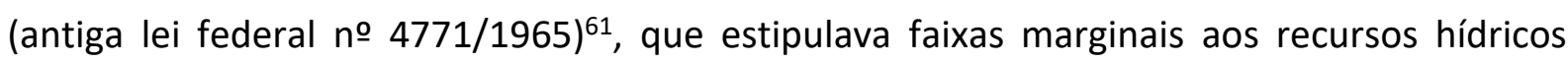
consideradas como Áreas de Preservação Permanente (APP) com largura mínima de 30 metros (LEONELLI, 2010).

O loteador deveria articular as vias propostas com as vias adjacentes oficiais, existentes ou projetadas, devendo o traçado viário harmonizar-se com a topografia local. Esta exigência contribuía para que o sistema de vias estivesse em congruência com o relevo.

A norma auxiliaria as prefeituras acerca dos procedimentos administrativos para a aprovação de projetos de parcelamento do solo urbano e guiaria a ação dos loteadores, que deveriam solicitar aos órgãos competentes as diretrizes para o parcelamento. Estas diretrizes

\footnotetext{
59 "Consideram-se comunitários os equipamentos públicos de educação, cultura, saúde, lazer e similares" (BRASIL, 1979, Art. 4ㅇ).

60 “Art. 5o - O Poder Público competente poderá complementarmente exigir, em cada loteamento, a reserva de faixa non aedificandi destinada a equipamentos urbanos. Parágrafo único. Consideram-se urbanos os equipamentos públicos de abastecimento de água, serviços de esgoto, energia elétrica, coletas de águas pluviais, rede telefônica e gás canalizado" (BRASIL, 1979).

${ }^{61}$ Atualmente, lei federal no 12.651/2012, que dispõe sobre a proteção da vegetação nativa, e na qual permanece esta exigência.
} 
deveriam traduzir-se na forma de projeto urbanístico com indicação em planta da área a ser loteada, da topografia, dos recursos naturais existentes e das características urbanas do entorno. A legislação tinha caráter de obrigatoriedade e, portanto, seu não cumprimento constituiria um crime contra a administração.

A lei passou por algumas revisões, sendo incluídos outros pontos para contemplar novas necessidades e suprir as falhas. Desses pontos, destacou-se a definição de infraestrutura básica dos parcelamentos como sendo: "equipamentos urbanos de escoamento das águas pluviais, iluminação pública, esgotamento sanitário, abastecimento de água potável, energia elétrica pública e domiciliar e vias de circulação" (BRASIL, 1979, Art. 2º). Entretanto, houve a exclusão da exigência de porcentagem mínima destinada às áreas públicas, ficando esta quantificação sob a responsabilidade do município ${ }^{62}$.

Salientou-se ainda a inclusão de dois parágrafos referentes à aprovação de projeto, incluídos pela Lei № 12.608/2012 que institui a Política Nacional de Proteção e Defesa Civil, numa tentativa de direcionar a urbanização para áreas mais aptas e, com isso, evitar que os desastres naturais implicassem perdas humanas. 0 primeiro parágrafo vinculou o atendimento dos requisitos constantes na carta geotécnica de aptidão à urbanização para os municípios inseridos no cadastro nacional de "áreas suscetíveis à ocorrência de deslizamentos de grande impacto, inundações bruscas ou processos geológicos ou hidrológicos correlatos"; o segundo parágrafo vetou "a aprovação de projeto de loteamento e desmembramento em áreas de risco definidas como não edificáveis, no plano diretor ou em legislação dele derivada" (BRASIL, 1979, Art. 12).

Quanto às revisões da lei, Leonelli (2010) atentou para a necessidade do resgate da discussão inicial desta regulamentação, que em seu processo constitutivo sofreu alguns desvirtuamentos de suas intenções. A autora também destacou entre os tópicos polêmicos destas revisões

a regulação e criação de loteamentos fechados e condomínios urbanos, a definição de infraestrutura básica para parcelamentos em zonas habitacionais de interesse social, a simplificação do processo de aprovação de loteamento, a flexibilização da legislação ambiental em áreas urbanas, o

\footnotetext{
62 "As áreas destinadas a sistemas de circulação, a implantação de equipamento urbano e comunitário, bem como a espaços livres de uso público, serão proporcionais à densidade de ocupação prevista pelo plano diretor ou aprovada por lei municipal para a zona em que se situem". (Redação dada pela Lei no 9.785, de 1999) (BRASIL, 1979, Art. 4ㅇ). Não há mais a ressalva sobre as áreas mínimas.
} 
estabelecimento de normas específicas para a regularização fundiária e seu registro imobiliário e, por fim, a previsão da licença integrada como substituição às licenças urbanística e ambiental (LEONELLI, 2010, p. 31).

A lei promoveu avanços na direção do campo do planejamento com a paisagem ao instituir a obrigatoriedade de áreas para a implantação espaços livres de uso público, na medida em que isto altera a paisagem. Outro ponto importante foi atentar para as características do meio físico, tanto quanto a conservação da natureza quanto como limitantes à edificação, aproximando-se das proposições de $\mathrm{McHarg}$ relacionadas à aptidão do lugar.

Bonduki (2014) considerou a Lei no 6766/1979 o mais importante instrumento urbanístico em nível nacional no período. Compreende-se o avanço na tentativa de disciplinar a ação dos loteadores, proporcionar condições urbanísticas razoáveis e estabelecer critérios para a doação de áreas públicas, assim como de articular minimamente as questões urbanas às questões ambientais. Contudo, a lei não impediu o crescimento urbano informal, que deriva de tantos outros fatores, como o econômico e a gestão urbana, muitas vezes relegada à ação de especuladores.

\section{Capítulo da Política Urbana na Constituição Federal de 1988}

O processo de redemocratização do país, marcado, entre outros aspectos, pela atuação dos movimentos sociais pela reforma urbana e o direito à cidade, propiciou a organização de um instrumento legal dedicado à questão urbana. $\mathrm{O}$ "Direito à Cidade e à Cidadania", a "Gestão Democrática da Cidade", a "Função Social da Cidade e da Propriedade" eram demandas destes movimentos sociais - até pouco tempo contidas pelo governo ditatorial - e resultaram da insatisfação com um modelo econômico excludente e espoliativo, que prevaleceu ao longo de décadas de intensa urbanização.

- Direito à Cidade e à Cidadania, entendido como uma nova lógica que universalizasse o acesso aos equipamentos e serviços urbanos, a condições de vida urbana dignas, ao usufruto de um espaço culturalmente rico e diversificado e, sobretudo, a uma dimensão política de participação ampla dos habitantes das cidades na condução de seus destinos.

- Gestão Democrática da Cidade, entendida como uma forma de planejar, produzir, operar e governar as cidades submetidas ao controle e participação social, destacando-se como prioritária a participação popular.

- Função Social da Cidade e da Propriedade, entendida como a prevalência do interesse comum sobre o direito individual de propriedade, o que implica 
o uso socialmente justo e ambientalmente equilibrado do espaço urbano (DE GRAZIA citado por BASSUL, 2002).

Houve a mobilização de entidades profissionais e acadêmicas junto aos movimentos sociais, que naquele momento estavam esperançosos diante da possibilidade de propor uma emenda popular à Constituição. Após longa negociação, a Constituição Federal de 1988, marco legal e institucional do período, apresentou o Capítulo "Da Política Urbana", com os artigos 182 e 183, em que ficam estabelecidos princípios e instrumentos para a promoção de políticas públicas de desenvolvimento e planejamento urbano e a plena a realização da função social da cidade e da propriedade urbana, uma grande conquista para os movimentos sociais que lutavam pela Reforma Urbana.

Art. 182. A política de desenvolvimento urbano, executada pelo Poder Público municipal, conforme diretrizes gerais fixadas em lei, tem por objetivo ordenar o pleno desenvolvimento das funções sociais da cidade e garantir o bem-estar de seus habitantes.

Art. 183. Aquele que possuir como sua área urbana de até duzentos e cinquenta metros quadrados, por cinco anos, ininterruptamente e sem oposição, utilizando-a para sua moradia ou de sua família, adquirir-lhe-á o domínio, desde que não seja proprietário de outro imóvel urbano ou rural. (BRASIL, 1988).

A função social da propriedade urbana estava atrelada à exigência de elaboração do plano diretor, que se tornou obrigatório para cidades com mais de vinte mil habitantes. Mais uma vez, o plano diretor foi colocado como instrumento básico da política urbana, embora não fosse uma reivindicação na emenda popular ${ }^{63}$.

É importante lembrar que a Constituição Federal (1988) trouxe também um Capítulo referente ao meio ambiente, tema que se fortalecia mundialmente a partir da discussão sobre os limites do crescimento e seus impactos sobre os recursos naturais.

Art. 225. Todos têm direito ao meio ambiente ecologicamente equilibrado, bem de uso comum do povo e essencial à sadia qualidade de vida, impondose ao Poder Público e à coletividade o dever de defendê-lo e preservá-lo para as presentes e futuras gerações (BRASIL, 1988).

O Capítulo colocou o poder público como responsável pela proteção e preservação dos ecossistemas e estabeleceu a definição de espaços territoriais especialmente protegidos, o

\footnotetext{
${ }^{63}$ Villaça (1999) considerou este fato um retrocesso, pois condicionar a aplicação dos instrumentos referentes à função social da propriedade ao plano diretor, seria uma maneira de ofuscar as questões centrais da Reforma Urbana. Ele apontou as dificuldades para a aplicação de sanções aos proprietários que não cumprissem a destinação social de suas propriedades. Além disso, naquele momento, os artigos referentes à Política Urbana ainda não estavam regulamentados por lei federal.
} 
que posteriormente originaria a lei do Sistema Nacional de Unidades de Conservação da Natureza (SNUC) (2000).

\section{Planos Diretores pós Constituição Federal de 1988}

Villaça (1999) considerou a década de 1990, por um lado, como o término de um período na história do planejamento urbano brasileiro e, por outro lado, como o início do processo de politização resultado do fortalecimento dos movimentos populares. Os planos diretores do início desta década tentaram incorporar os temas da reforma urbana, atentando para o cumprimento da determinação constitucional. No entanto, houve alguns entraves e resistências a esse processo.

Numa distinção aos planos diretores dos anos anteriores, que pretendiam abordar todas as temáticas relativas à cidade e fazer extensos diagnósticos, os planos da década de 1990 tendiam a se limitar aos aspectos de competência municipal, destacando-se aqueles relacionados ao espaço urbano. Na intenção de cumprir a função social da propriedade (Constituição Federal de 1988), os planos tentaram introduzir dispositivos como o Coeficiente de Aproveitamento único igual a um para toda a cidade, a Concessão Onerosa do Potencial Construtivo, o Fundo Municipal de Urbanização, as Zonas Especiais de Interesse Social (ZEIS), o Imposto sobre a Propriedade Predial e Territorial Urbana Progressivo no Tempo (IPTU). Contudo, a regulamentação dos artigos 182 e 183 da Constituição Federal de 1988, ou seja, a regulamentação dos instrumentos da Política Urbana, viria a acontecer somente alguns anos mais tarde através do Estatuto da Cidade (Lei no 10.257/2001), o que dificultou a sua aplicação. Além disso, essa aplicação encontrou oposição de diversos setores do empresariado e grupos ligados ao setor imobiliário.

Foram realizados muitos debates na tentativa de implementar esses instrumentos, no entanto, alguns planos diretores do período cederam às pressões dos setores imobiliários.

Para os movimentos populares, especialmente os ligados à terra e à habitação, o plano diretor tornou-se um instrumento desgastado em virtude das possibilidades que vinha apresentando de ser manipulado e desvirtuado pelos setores reacionários que dominavam a produção do espaço urbano. Consequentemente, a elaboração de vários planos diretores para importantes cidades do país no início dos anos 1990 não conseguiu organizar os movimentos populares urbanos (VILLAÇA, 1999, p. 237). 
Schvarsberg (2011) afirmou que após 1988 os planos diretores, ao modo do Planejamento e Planos Estratégicos, apresentaram um viés empresarial ${ }^{64}$. Entretanto, não havia um modelo pronto para ser aplicado, de modo que o autor considerou esta configuração “[...] um processo próprio de experimentação, rico e contraditório, uma espécie de híbrido urbanístico de múltiplas influências e matrizes conceituais, empíricas e ideológicas" (SCHVARSBERG, 2011, p. 22).

\section{Estatuto da Cidade}

A regulamentação dos artigos 182 e 183 da Constituição Federal de 1988 aconteceu em 2001 quando foi aprovada a Lei Federal no 10.257/2001, denominada "Estatuto da Cidade", que estabeleceu as diretrizes gerais da política urbana. Esta aprovação significou um marco histórico para a política urbana nacional, proporcionando avanços: suporte às políticas públicas de inclusão socioespacial e de democratização de acesso ao solo urbano e à moradia nas cidades; implementação de uma gestão urbana justa, através da participação popular nos processos decisórios, como também pela admissão da necessidade de apropriação pela comunidade de parcela da valorização imobiliária (FERNANDES, 2013).

Este regulamento articula o direito à cidade e a compatibilização das ações humanas com o ambiente natural, visando a promoção do equilíbrio ambiental e da sustentabilidade ${ }^{65}$,

\footnotetext{
${ }^{64}$ Peres (2012) ressaltou que no início dos anos 1990, ao mesmo tempo em que ocorreram as conquistas sociais inscritas na Constituição Federal de 1988, fortalecia-se no Brasil a visão neoliberal, que entendia a terra e a moradia como mercadorias.

${ }^{65}$ Remete às discussões sobre desenvolvimento sustentável, no momento de retomada de consciência ambiental. "O desenvolvimento sustentável é o desenvolvimento que encontra as necessidades atuais sem comprometer a habilidade das futuras gerações de atender suas próprias necessidades" (Relatório Brundtland citado por ONU). Este conceito foi elaborado pela Comissão Mundial sobre o Meio Ambiente e Desenvolvimento e publicado no Relatório Brundtland ("Nosso Futuro Comum") em 1987. As recomendações feitas nesse relatório levaram à realização da Conferência das Nações Unidas sobre o Meio Ambiente e o Desenvolvimento, realizada no Rio de Janeiro em 1992 (Rio 92), que colocou o assunto diretamente na agenda pública, conhecida como Agenda 21.
} 
conceito relacionado às temáticas da Agenda $21^{66}$ e aos preceitos da Agenda Habitat ${ }^{67}$, agendas políticas globais. Estão entre as diretrizes gerais:

I - a garantia do direito a cidades sustentáveis, entendido como o direito à terra urbana, à moradia, ao saneamento ambiental, à infraestrutura urbana, ao transporte e aos serviços públicos, ao trabalho e ao lazer, para as presentes e futuras gerações;

IV - planejamento do desenvolvimento das cidades, da distribuição espacial da população e das atividades econômicas do Município e do território sob sua área de influência, de modo a evitar e corrigir as distorções do crescimento urbano e seus efeitos negativos sobre o meio ambiente; (BRASIL, 2001, Cap. I, art. 2º).

As outras diretrizes também seguiram esta linha de desenvolvimento sustentável ao tratar da ordenação e controle do uso do solo de forma a evitar a poluição e a degradação ambiental; ao sugerir a "adoção de padrões de produção e consumo de bens e serviços e de expansão urbana compatíveis com os limites da sustentabilidade ambiental, social e econômica do Município e do território sob sua área de influência"; e ao promover a "proteção, preservação e recuperação do meio ambiente natural e construído, do patrimônio cultural, histórico, artístico, paisagístico e arqueológico” (BRASIL, 2001, Cap. I, art. 2o). Tais diretrizes são fundamentais na direção de um planejamento urbano em congruência com o meio natural e em consideração às questões que compõem a paisagem urbana.

O Estatuto colocou uma série de instrumentos para auxiliar a política urbana que também tocam diretamente na temática ambiental, tendo como exemplos: "Zoneamento Ambiental"; "Instituição de Unidades de Conservação"; "Estudo Prévio de Impacto Ambiental (EIA) e o Estudo Prévio de Impacto de Vizinhança (EIV)".

Outros instrumentos incluíram a temática ambiental indiretamente, a saber: "Direito de Preempção", que pode ser exercido com a finalidade de "criação de espaços públicos de lazer e áreas verdes"; "criação de unidades de conservação ou proteção de outras áreas de

\footnotetext{
${ }^{66}$ A Agenda 21 é um documento assinado por 179 países incluindo o Brasil, sendo o principal resultado da 'Conferência das Nações Unidas para o Meio Ambiente e Desenvolvimento', realizado no Rio de Janeiro em 1992 (Rio 92). Agenda 21 é um plano abrangente de ação a ser adotado globalmente, nacionalmente e localmente por organizações do Sistema das Nações Unidas, Governos e grandes grupos em todas as áreas onde ocorrem impactos humanos sobre o meio ambiente. Pode ser definida como um "instrumento de planejamento participativo visando o desenvolvimento sustentável" (CNUMAD, 1995).

${ }^{67}$ Plano de Ação Global, produzido na 2a Conferência Mundial Sobre os Assentamentos Humanos, realizada pelo Programa das Nações Unidas para os Assentamentos Humanos (ONU-Habitat). Este documento orientava a definição de padrões globais para alcance do desenvolvimento urbano sustentável, repensando a forma como as cidades eram construídas, gerenciadas e vividas (ONU).
} 
interesse ambiental"; "proteção de áreas de interesse histórico, cultural ou paisagístico" (BRASIL, 2001, Cap. II, art. 26ㅇ). E a "Outorga Onerosa do Direito de Construir", em que os recursos financeiros arrecadados poderiam ser aplicados para as mesmas finalidades destacadas acima. A lei instituiu também as "Zonas Especiais de Interesse Social" (ZEIS) para a demarcação de áreas reservadas à habitação social, com o intuito de destinar locais atendidos por infraestrutura dentro da malha urbana e ambientalmente compatíveis com o uso habitacional.

O Estatuto estabeleceu o plano diretor como instrumento central para o ordenamento da política de desenvolvimento e expansão urbana e ampliou os casos de obrigatoriedade de elaboração do plano diretor. Incluiu cidades que anteriormente à aprovação desta lei não tinham um marco jurídico adequado para orientar a urbanização, sendo que em muitos municípios inexistiam informações básicas sobre seus próprios territórios (FERNANDES, 2013, p. 216).

\footnotetext{
O plano diretor é obrigatório para cidades:

II - integrantes de regiões metropolitanas e aglomerações urbanas;

III - onde o Poder Público municipal pretenda utilizar os instrumentos previstos no $\S 4$ ㅇ do art. 182 da Constituição Federal; IV - integrantes de áreas de especial interesse turístico; $V$ - inseridas na área de influência de empreendimentos ou atividades com significativo impacto ambiental de âmbito regional ou nacional.

VI - incluídas no cadastro nacional de Municípios com áreas suscetíveis à ocorrência de deslizamentos de grande impacto, inundações bruscas ou processos geológicos ou hidrológicos correlatos (BRASIL, 2001, Cap. III, art. $41 \%$ ).
}

Destaca-se a inclusão, pela Lei no 12.608/2012 (Política Nacional de Proteção e Defesa Civil), da situação trazida pelo inciso VI supracitado, de relevância diante dos desastres naturais vivenciados nestes últimos anos, temática que também foi incluída na Lei no 6766/1979 conforme mostrado anteriormente.

Araújo (2003, p. 11) avaliou positivamente o potencial trazido pelo Estatuto da Cidade referente à temática ambiental dentro do contexto do desenvolvimento sustentável, pois “[...] cidades democraticamente planejadas e socialmente mais justas colocam-se em associação direta com um desenvolvimento urbano que gera menos efeitos perversos sobre os recursos naturais". Pela primeira vez foi claramente articulada a ideia de crescimento urbano em 
conflito com o meio ambiente, colocada por uma normativa ligada ao campo do planejamento urbano.

Para Martins (2012) os planos diretores passaram a expressar a preocupação com o ambiente e com as questões sociais em suas diretrizes, mas persiste o desafio de tradução destas diretrizes na forma urbana.

Enunciados nos vigentes "instrumentos de planejamento" e da "reforma urbana", colocam em foco objetivos quanto ao desenvolvimento urbano, mas estão longe de aproximar-se de qualquer imagem de configuração urbana. A cidade em sua forma física permanece com poucas utopias e sem uma forma física que expresse e materialize tais objetivos (MARTINS, 2012, p. 157)

$\mathrm{Na}$ medida em que os novos planos diretores foram sendo elaborados, a temática ambiental aparecia nas discussões como contenção da ocupação em áreas de mananciais, em fundos de vale e em áreas de preservação permanente, determinando a criação de áreas de proteção. Entretanto, a abordagem ambiental nos planos diretores ainda aparece vinculada à preservação de áreas verdes e desvinculada da política de ordenamento territorial e das outras políticas setoriais (COSTA et al., 2011), revelando grande dificuldade em romper com a lógica setorial. Apesar de estabelecer que o plano diretor deve englobar o território municipal como um todo, a lei não apresentou subsídios para disciplinar o uso e ocupação do solo rural, permanecendo a demanda em se propor mecanismos efetivos na minimização do conflito entre o desenvolvimento humano e o ambiente natural.

A Lei Federal no 10.257/2001 se inseriu no amplo processo de reforma jurídica que ocorria no Brasil há três décadas e tinha as Leis Federais no 6.766/1979 (Parcelamento do Solo Urbano) e a Constituição Federal de 1988 como principais antecedentes diretos. Conforme Fernandes (2013), uma série outras leis federais ${ }^{68}$ complementaram o Estatuto das Cidades desde sua aprovação, constituindo uma nova e sofisticada ordem jurídico-urbanística, comprometida com a agenda sociopolítica da reforma urbana. Entre os desdobramentos de ordem institucional, sucedeu-se a criação do Ministério das Cidades em 2003; a convocação de Conferências Nacionais, Estaduais e Municipais das Cidades; e a instalação e ação do

\footnotetext{
${ }^{68}$ Por exemplo: leis federais no 11.445/2007 (Política de Saneamento); no 11.977/2009 (criou o Programa “Minha Casa, Minha Vida" - PMCMV e dispôs sobre regularização fundiária); no 12.608/2012 (Política Nacional de Defesa e Proteção Civil), entre outras.
} 
Conselho Nacional das Cidades, na direção de promover a participação social e a gestão democrática ${ }^{69}$.

Decorridos quase vinte anos após a promulgação do Estatuto das Cidades, os desafios na direção de um desenvolvimento urbano, social e ambientalmente equilibrado amplificaram-se frente a uma nova realidade em que

As taxas de crescimento urbano no país certamente caíram, mas ainda são relativamente altas, agora especialmente nas cidades pequenas e de médio porte, levando à formação de um novo sistema de regiões metropolitanas, com 30 delas já reconhecidas oficialmente. $O$ crescimento econômico do país e a formação de uma "nova classe média"/ "classe trabalhadora precária" têm agravado problemas urbanos há muito existentes de transporte público e mobilidade, impacto ambiental e violência urbana. Diversos problemas de infraestrutura urbana e a crise energética nas cidades também têm se manifestado e agravado de diversas formas. A crise fiscal das administrações públicas, especialmente no âmbito municipal, é generalizada (FERNANDES, 2013, p. 216).

\subsection{Lógicas que orientam as Políticas Urbanas e Ambientais}

Schvarsberg (2011) afirmou que na Política Urbana prevaleceu uma visão setorialista, em que o território era entendido pela sua divisão em "setores" - do meio ambiente, do urbanismo, da saúde etc., conforme foi mencionado anteriormente. $\mathrm{O}$ autor criticou a leitura fragmentada da cidade, compreendida como soma de loteamentos produzidos por um processo privatista, concepção que prevaleceu na lei no 6766/1979. O setorialismo estaria historicamente atrelado à concepção e à prática dominante no meio técnico e político do planejamento urbano. Tal concepção seria ineficaz no processo de gestão do território, resultando em dificuldades ao desenvolvimento urbano, por exemplo, no enfrentamento do desafio de localização das Zonas de Especial Interesse Social em áreas centrais e em congruência com o ambiente natural.

Para Costa (2008), o encontro da temática ambiental com o planejamento urbano evidenciou as distintas racionalidades que originaram e direcionaram ambas as questões em percursos temporais e políticos também distintos. Essa articulação teve início a partir da

\footnotetext{
${ }^{69}$ Em 2019, o Ministério das Cidades e o Ministério da Integração Nacional foram fundidos e transformados em Ministério do Desenvolvimento Regional. O Decreto no 9.076/2017 tirou do Conselho Nacional das Cidades o poder de convocar e organizar a Conferência Nacional das Cidades.
} 
década de 1980, período de transformação da temática ambiental de uma política setorial em um campo de lutas e intervenções, marcado pela tendência de constituição de um campo socioambiental amplo, que incorporou aos poucos as questões urbanas. Tanto as políticas ambientais quanto as políticas urbanas agregaram princípios como a justiça social, a participação popular e a sustentabilidade em suas diretrizes e instrumentos, elementos compartilhados pelas políticas públicas conforme proposto pela Constituição de 1988 (COSTA, 2008). A autora destacou que o reconhecimento deste avanço, no entanto, não pressupôs a eliminação de conflitos sociais ou a construção de um consenso. Na intenção de compreender esse percurso, ela apresentou as racionalidades orientadoras dessas temáticas e os marcos que constituem suas trajetórias pelo ponto de vista do planejamento urbano.

Segundo a autora a regulação urbanística está atrelada à modernização do espaço urbano nos moldes da produção capitalista na fase industrial, ao passo que o debate ambiental surgiu do questionamento dos desdobramentos dessa modernidade relacionados ao desenvolvimento e suas mazelas, e está vinculado aos movimentos sociais e culturais dos anos 1960 e 1970.

A lógica do ordenamento territorial remonta à visão funcionalista, em que o planejamento estava vinculado à ordem e à legalidade, correspondentes respectivamente ao desenho urbano regular ${ }^{70}$ e ao processo legal de produção do espaço ${ }^{71}$. Assim, de acordo com Costa (2008, p. 86), o que fosse diferente disso seria considerado "desordenado, irregular e/ou ilegal", depositando toda responsabilidade de "salvar" a cidade sobre o planejamento urbano e desconsiderando a importância das políticas públicas. Conforme a autora, embora essa lógica já estivesse superada na formulação das políticas públicas urbanas, ainda repercutia em alguns planos diretores recentes.

Outra lógica do ordenamento territorial é a da recuperação do investimento público como medida promotora de justiça socioespacial ${ }^{72}$. O investimento público que gerou a valorização fundiária e imobiliária deveria retornar aos cofres públicos, através de

\footnotetext{
${ }^{70}$ Costa (2008) exemplificou o desenho urbano regular com as seguintes correntes: modernismo, culturalismo, de vanguarda, orgânico, experimental.

${ }^{71}$ Referente à legislação que regulamenta o acesso à terra, o projeto, a construção e a comercialização (COSTA, 2008).

72 Referente a luta dos movimentos sociais por moradia e terrenos seguros, bem localizados, servidos de infraestrutura urbana e equipamentos públicos, conforme apresentado anteriormente.
} 
instrumentos tributários como a contribuição de melhoria. É interessante observar o questionamento acerca dos vazios urbanos, que, dentro dessa lógica, contribuem para a especulação imobiliária e para o espraiamento da malha urbana, constituindo-se na subutilização da infraestrutura instalada. Para que se cumpra a função social da propriedade, - Estatuto da Cidade trouxe os instrumentos: "Parcelamento, Edificação ou Utilização Compulsórios", "Imposto sobre a Propriedade Predial e Territorial Urbana", "Desapropriação com Pagamento em Títulos", “Usucapião Especial de Imóvel Urbano”. Entretanto, pela lógica ambiental, esses vazios urbanos poderiam ter uso social ou outros usos produtivos e diferentes da edificação (COSTA, 2008).

A política ambiental é orientada por duas lógicas: a da preservação e a da valoração econômica da natureza, que se refletem na regulação urbanística de diferentes maneiras. A lógica da preservação retomou a noção de espaço intocado pela necessidade de proteger o território, numa reação ao avanço urbano-industrial, que começou no século XIX. Atualmente, existe uma diferenciação ${ }^{73}$ entre os termos preservação e conservação, estando o primeiro associado à proteção da natureza e o segundo ao seu uso racional e controlado. Na legislação brasileira, o uso destes termos no Sistema Nacional de Unidades de Conservação (SNUC) corresponde respectivamente às categorias de Unidades de Proteção Integral e Unidades de Uso Sustentável ${ }^{74}$.

Costa (2008) apontou ainda os conflitos atrelados à criação das Unidades de Proteção Integral e os habitantes destas áreas, conflito que encontrou paralelo no caso das Áreas de Preservação Ambiental (APP) urbanas, que não poderiam ser ocupadas. Entretanto, a ocupação das margens de cursos d'águas remete à origem de muitas cidades brasileiras, que cresceram no entorno de rios, bem como se relaciona ao crescimento urbano das décadas de 1970 e 1980, em áreas ambientalmente sensíveis como as várzeas, os mangues, as encostas.

\footnotetext{
${ }^{73} \mathrm{O}$ debate sobre esse assunto envolve várias disciplinas e contrapõe correntes ideológicas. Neste trabalho apresentou-se a distinção dos termos de maneira simplificada, apenas para compreensão das origens da temática ambiental e sua imbricação no planejamento urbano.

${ }^{74}$ Lei federal no 9.985/2000 que regulamenta o art. 225 (Capítulo VI Do Meio Ambiente), § 1o, incisos I, II, III e VII da Constituição Federal. “§ 1으 O objetivo básico das Unidades de Proteção Integral é preservar a natureza, sendo admitido apenas o uso indireto dos seus recursos naturais, com exceção dos casos previstos nesta Lei. §2응 O objetivo básico das Unidades de Uso Sustentável é compatibilizar a conservação da natureza com o uso sustentável de parcela dos seus recursos naturais" (BRASIL, 2000, Capítulo III, Art. 7으).
} 
De acordo com o Código Florestal ${ }^{75}$, estes espaços denominados Áreas de Preservação Ambiental devem ser protegidos e não ocupados. Costa (2008) apontou para a dupla lógica dessa proteção, associada à proteção do ambiente e da própria população, frente ao risco oferecido por estas áreas.

O Código Florestal passou por revisões e, as ocupações existentes nas APPs se tornaram passíveis de regularização no caso de interesse social, conforme a definição do Código: "a regularização fundiária de assentamentos humanos ocupados predominantemente por população de baixa renda em áreas urbanas consolidadas, observadas as condições estabelecidas na Lei no 11.977, de 7 de julho de 200976" (BRASIL, 2012, Capítulo I, Art. 3ㅇ). No entanto, a ocupação de APP caracteriza uma situação de vulnerabilidade social, dado que são locais suscetíveis a alagamentos e deslizamentos.

$\mathrm{Na}$ tentativa de resolver a situação de risco à vida ou à saúde dos ocupantes nessas áreas, a Medida Provisória no $2.220 / 2001^{77}$ previu a possibilidade do poder público garantir o direito de concessão de uso especial para fins de moradia em outro local. Araújo (2003) apontou a necessidade de discussões mais aprofundadas e análise de cada caso, pois nem todas os assentamentos humanos poderiam ser regularizados, bem como o poder público dificilmente conseguiria desabrigar essas pessoas.

Como um princípio maior a ser respeitado, os direitos da coletividade em relação ao meio ambiente ecologicamente equilibrado, também assegurados pela Constituição Federal, devem ser colocados acima dos direitos individuais ou de uma comunidade determinada. No entanto, o Poder Público não deve e nem de perto conseguiria simplesmente desalojar as incontáveis famílias em áreas ambientalmente protegidas. As situações devem ser estudadas especificamente e tratadas, também, especificamente. A urbanização de favelas, sem dúvida alguma um dos mais importantes instrumentos de garantia da integração social da população de baixa renda, é um caminho necessário, mas não poderá ser concretizado em todos os casos (ARAÚJO, 2003, p. 7).

\footnotetext{
${ }^{75}$ Lei no 12.651 de 25 de maio de 2012, que dispõe sobre a proteção da vegetação nativa; também denominado Código Florestal. Entende por Área de Preservação Permanente (APP): “área protegida, coberta ou não por vegetação nativa, com a função ambiental de preservar os recursos hídricos, a paisagem, a estabilidade geológica e a biodiversidade, facilitar o fluxo gênico de fauna e flora, proteger o solo e assegurar o bem-estar das populações humanas" (BRASIL, 2012, Capítulo I, Art. 3ㅇ).

${ }^{76}$ Que dispõe a regularização fundiária de assentamentos localizados em áreas urbanas.

77 Medida Provisória no 2.220, de 4 de setembro de 2001, dispõe sobre a concessão de uso especial de que trata o § 10 do art. 183 da Constituição, também cria o Conselho Nacional de Desenvolvimento Urbano - CNDU.
} 
Ainda dentro da modalidade de interesse social, o Código Florestal permitiu a “implantação de infraestrutura pública destinada a esportes, lazer e atividades educacionais e culturais ao ar livre em áreas urbanas e rurais consolidadas, observadas as condições estabelecidas nesta Lei" (BRASIL, 2012, Capítulo I, Art. 3ํ), usos compatíveis com os parques. Também permitiu a intervenção ou a supressão de vegetação nativa de APPs no caso de utilidade pública e no caso de atividades baixo impacto ambiental previstas na lei.

Retomando a segunda lógica que conduz a política ambiental, a valoração econômica da natureza expressou-se pela atribuição de valor, às vezes monetário, pelo uso, apropriação, deterioração ou desgaste dos bens ambientais (COSTA, 2008). Essa valoração incorporou a visão econômica, na qual a natureza é compreendida como um conjunto de recursos naturais destinados à satisfazer as necessidades humanas. Notou-se a utilização desta racionalidade nos instrumentos da gestão ambiental, como na cobrança pelo uso dos recursos (por exemplo da água); no princípio poluidor pagador; no estabelecimento de cotas de poluição; fato discutível diante da sensação de que é possível explorar a natureza sem consequências.

Bens coletivos metamorfoseado em recursos apropriados por aqueles que pagam passam a ter o direito de uso e, eventualmente, de deterioração dos mesmos. Em outras palavras, a atribuição de valor econômico se transforma em direito de apropriação, muitas vezes em detrimento de usos tradicionais coletivos ou não. Se tudo está reduzido um preço, trata-se então de discutilo? Esta lógica, transformada em política pública, requer necessariamente mecanismos eficientes de controle social. É interessante observar que tais princípios foram rapidamente incorporados à política urbana e a regulação urbanística, na forma de operações interligadas, medidas compensatórias diversas, medidas mitigadoras, entre outras (COSTA, 2008, p. 90).

A incorporação desta lógica à política urbana e legislação urbanística, pode ser observada no Plano Diretor Estratégico do Município de São Paulo, que apresentou uma série de instrumentos de compensação ambiental, entre eles:

Art. 154. O Termo de Compromisso Ambiental (TCA) é instrumento a ser firmado entre o órgão municipal integrante do SISNAMA e pessoas físicas ou jurídicas, referente a contrapartidas, obrigações e compensações nos casos de:

I - autorização prévia para supressão de espécies arbóreas;

II - intervenções em área de preservação permanente, com ou sem manejo arbóreo;

III - licenciamento ambiental de empreendimentos com significativa emissão de gases de efeito estufa; 
IV - transferência do potencial construtivo sem previsão de doação de área, aplicada a imóveis grafados como ZEPAM localizados na Macrozona de Estruturação Urbana (SÃO PAULO, 2014, p. 9).

Ainda dentro da lógica ambiental, é possível encontrar instrumentos reguladores como o licenciamento ambiental. O licenciamento ambiental ${ }^{78}$ é o procedimento administrativo realizado por um órgão ambiental competente com o objetivo de avaliar os impactos negativos referentes à atividades ou empreendimentos sobre o meio ambiente, com a intenção de evitá-los ou minimizá-los. Este instrumento encontrou correspondência no Estatuto da Cidade com o Estudo de Impacto De Vizinhança79 (EIV), em que são avaliados os efeitos positivos e negativos de empreendimento ou atividade de grande porte quanto à qualidade de vida da população residente na área e suas proximidades (BRASIL, 2001). No caso de novos loteamentos, o EIV analisa questões relacionadas ao adensamento populacional e suas consequências como sobrecarga da infraestrutura urbana, assim como o impacto na paisagem urbana (ARAÚJO, 2003).

Contudo, existem críticas ao licenciamento ambiental e quanto à sua efetividade na incorporação na regulação urbanística. Como levantado por Costa (2008), o licenciamento passa a ideia de inevitabilidade do impacto causado pelo empreendimento ou atividade, ao mesmo tempo em que estipula alternativas para minimizá-lo ou compensá-lo. O licenciamento teria sido elaborado para avaliar atividades pontuais quanto à sua localização, seu funcionamento e seus impactos no entorno imediato. Ao transpor este instrumento para o contexto urbano, seria necessária sua adequação, por exemplo para avaliar novos parcelamentos.

\footnotetext{
${ }^{78}$ Licenciamento Ambiental, um instrumento da Política Nacional do Meio Ambiente, lei federal no 6.938, de 31 de agosto de 1981, proposto em casos de "construção, instalação, ampliação e funcionamento de estabelecimentos e atividades utilizadores de recursos ambientais, efetiva ou potencialmente poluidores ou capazes, sob qualquer forma, de causar degradação ambiental [...]" (BRASIL, 1981, Art. 10). A Resolução CONAMA no 237 de 19 de dezembro de 1997, estipulou quais seriam as atividades ou empreendimentos sujeitos ao licenciamento ambiental. A Resolução CONAMA no 001, de 23 de janeiro de 1986, determinou quais empreendimentos deveriam obrigatoriamente apresentar Estudo de Impacto Ambiental e Relatório de Impacto Ambiental (EIA/RIMA) no processo de licenciamento.

${ }^{79}$ E elaboração do estudo Prévio de Impacto de Vizinhança (EIV) não substitui a elaboração do Estudo de Impacto Ambiental (EIA). O EIA seria um requisito da licença ambiental exigida pela Política Nacional do Meio Ambiente e deveria ser analisado por um órgão federal, enquanto o EIV seria analisado por um órgão municipal (ARAÚJO, 2003).
} 


\title{
2.5 Aproximações da gestão urbana e ambiental
}

Segundo Maricato (2000), ao analisar os impactos sobre o meio natural decorrentes do processo de urbanização, a maior gravidade foi verificada na área de recursos hídricos e saneamento. Considerando que muitas cidades se originaram nas proximidades dos cursos d'água e que boa parte das atividades humanas dependem dos recursos hídricos para sobrevivência, tal constatação é esperada. Da ocupação inadequada das áreas ambientalmente frágeis no entorno dos cursos d'água decorreram problemas urbanoambientais como degradação de ecossistemas, poluição, enchentes, que resultaram em prejuízos humanos, materiais e ambientais. A degradação ambiental derivada da ocupação inadequada dessas áreas, sucedeu-se não apenas pela supressão da vegetação em APPs, como também pela desconsideração dos processos naturais responsáveis pela manutenção dos ecossistemas.

\begin{abstract}
A água doce é um recurso finito e vulnerável, essencial para sustentar a vida, o desenvolvimento e o meio ambiente.

Desde que a água sustenta a vida, a gestão eficaz dos recursos hídricos exige uma abordagem holística, vinculando o desenvolvimento social e econômico com a proteção dos ecossistemas naturais. Uma gestão eficaz conecta os usos da terra e da água em toda a área de uma bacia hidrográfica ou aquífero de águas subterrâneas (WMO, 1992) ${ }^{80}$.
\end{abstract}

No início dos anos 1990 a gestão de recursos hídricos baseada no recorte territorial das bacias hidrográficas foi retomada ${ }^{81}$ com os Princípios de Dublin (o primeiro princípio está destacado acima), que foram formulados na Conferência Mundial das Nações Unidas sobre Água e Meio Ambiente em uma reunião preparatória para a Rio-92.

Nesse período, vários fatores apontavam na direção de uma gestão urbana e ambiental integradora e, com essa perspectiva, a Constituição Federal de 1988 alterou ${ }^{82}$ o registro de domínio de todos recursos hídricos em território nacional, passando a ser bens da União:

\footnotetext{
${ }^{80}$ World Meteorological Organization (WMO) é o site onde foi publicado o Relatório The Dublin Statement and Report of the Conference. International Conference on Water and the Environment: Development Issues for the 21st Century. 26-31 January 1992. Dublin, Ireland. Consultou-se a versão traduzida 'A Declaração de Dublin sobre Água e Desenvolvimento Sustentável” por Johann Gnadlinger. Disponível em: < http://www.abcmac.org.br/files/downloads/declaracao_de_dublin_sobre_agua_e_desenvolvimento_sustenta vel.pdf >. Consultado em: 25 jun. 2017.

${ }^{81}$ Este recorte territorial de planejamento e gestão já foi utilizado no passado, tanto em âmbito internacional quanto nacional, conforme será mostrado adiante.

${ }^{82}$ Anteriormente, a dominialidade era definida pelo Código de Águas de 1934 (Decreto no 24.63/1934).
} 
III - os lagos, rios e quaisquer correntes de água em terrenos de seu domínio, ou que banhem mais de um Estado, sirvam de limites com outros países, ou se estendam a território estrangeiro ou dele provenham, bem como os terrenos marginais e as praias fluviais (BRASIL, 1988, Art. 20).

E bens do Estado, "as águas superficiais ou subterrâneas, fluentes, emergentes e em depósito, ressalvadas, neste caso, na forma da lei, as decorrentes de obras da União" (BRASIL, 1988, Cap. III, Art. 26, inciso I). Porto e Porto (2008), ressaltaram que a dominialidade referese às águas e não à bacia hidrográfica, que é um território, sendo este regido por outros regulamentos. Deste modo, a gestão da bacia hidrográfica, tendo em vista a gestão compartilhada da água, demanda a articulação de atribuições e das competências dos quatro entes federativos (União, Estados, Distrito Federal e Municípios). A Constituição de 1988 também atribuiu à União o dever de "instituir sistema nacional de gerenciamento de recursos hídricos e definir critérios de outorga de direitos de seu uso" (BRASIL, 1998, Art. 21, inciso

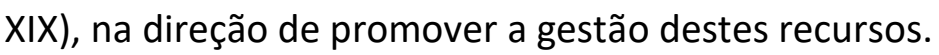

Na trajetória percorrida em direção à institucionalização dos recursos hídricos, a promulgação da Política Nacional de Recursos Hídricos (PNRH) - Lei Federal no 9.433/1997 e a criação do Sistema Nacional de Gerenciamento de Recursos Hídricos ${ }^{83}$ (SINGREH) são marcos, que de acordo com Porto e Porto (2008), colocaram o Brasil entre os países de legislação mais evoluída do mundo nesse setor.

A PNRH pretende a integração com políticas setoriais locais - saneamento básico, uso e ocupação do solo, meio ambiente - assim como a articulação dos poderes e executivos federais e locais, em vista disso algumas das diretrizes apontaram para:

II - a adequação da gestão de recursos hídricos às diversidades físicas, bióticas, demográficas, econômicas, sociais e culturais das diversas regiões do País;

IV - a integração da gestão de recursos hídricos com a gestão ambiental; V - a articulação da gestão de recursos hídricos com a do uso do solo; (BRASIL, 1997, Cap. III, Art. 3ㅇ).

A Política Nacional de Recursos Hídricos abordou a água como um bem de domínio público, dotado de valor econômico, assim, previu a participação dos usuários e representantes das organizações civis de recursos hídricos no Conselho Nacional de Recursos

\footnotetext{
${ }^{83}$ O Sistema Nacional de Gerenciamento de Recursos Hídricos (SINGREH) possui como principal função, realizar a gestão dos usos da água de forma democrática e participativa e implementar a Política Nacional de Recursos Hídricos (ANA).
} 
Hídricos e nos Comitês de Bacia Hidrográfica ${ }^{84}$. Deste modo, a população poderia intervir na gestão destes recursos, o que garantiria a legitimidade às decisões.

Para viabilizar os objetivos da Política Nacional de Recursos Hídricos, foram propostos seis instrumentos ${ }^{85}$ de gestão que de acordo com Porto e Porto (2008) visam atender as expectativas da comunidade tendo em vista os limites impostos pela aptidão natural das bacias hidrográficas, tanto na perspectiva utilitarista quanto para a preservação ambiental, garantindo sua sustentabilidade. Instrumentos centrais na gestão, os Planos de Recursos Hídricos, foram definidos como planos diretores que pretendem "fundamentar e orientar a implementação da Política Nacional de Recursos Hídricos e o gerenciamento dos recursos hídricos" (BRASIL, 1997, Art. 60). Os Planos devem conter diagnósticos e prognósticos, alternativas de compatibilização, metas, estratégias, programas e projetos, contemplando os recursos hídricos superficiais e subterrâneos da Bacia Hidrográfica levantada (CNRH, 2001, Art. 8ㅇ).

A Política Nacional de Recursos Hídricos reconheceu a bacia hidrográfica como unidade de planejamento e gestão e, em vista disso, os Planos de Recursos Hídricos devem ser elaborados em nível Nacional, Estadual e da Bacia Hidrográfica ${ }^{86}$ (Planos de Bacias Hidrográficas). Conforme os Planos Estaduais de Recursos Hídricos (PERH) foram sendo elaborados, os Estados podiam perceber a situação em que se encontravam seus recursos hídricos e projetar metas e estratégias para o futuro. Ao definir as aptidões da bacia hidrográfica, o Plano de Bacia direcionaria a gestão territorial, incentivando ou reprimindo atividades em uma região (PORTO; PORTO, 2008).

Deste modo, a bacia hidrográfica como unidade de planejamento e gestão do território apresenta um grande potencial de integração entre o uso do solo e a conservação dos recursos

\footnotetext{
${ }^{84}$ Os Comitês de Bacia Hidrográfica seriam órgãos colegiados, que desempenhariam o papel de coordenação e de deliberação em diferentes níveis do poder público, sendo responsáveis pela aprovação do Plano de Bacias e pela articulação entre os diversos agentes, como as instâncias de governo, os setores institucionais e usuários (ANA).

${ }^{85}$ Instrumentos da PNRH: Planos de Recursos Hídricos, Enquadramento dos corpos de água, Outorga dos direitos de uso, Cobrança pelo uso de recursos hídricos, Sistema Nacional de Informações sobre Recursos Hídricos (SNIRH); Compensação aos municípios (BRASIL, 1997, Art. 5ㅇ).

86 O Plano Nacional de Recursos Hídricos e os Planos Estaduais de Recursos Hídricos estabelecem respectivamente as diretrizes gerais sobre os recursos hídricos do País e de cada Estado. O Plano de Recursos Hídricos por Bacia Hidrográfica é o instrumento de planejamento local onde se define como conservar, recuperar e utilizar os recursos hídricos da bacia (COGERH).
} 
naturais, bem como, o potencial de articulação das instituições responsáveis por esta gestão. Para garantir a integração entre a gestão ambiental e a gestão territorial seria necessária a articulação de instrumentos desses dois campos disciplinares, assim como das esferas políticas e sociais (TRAVASSOS; SCHULT, 2013).

No entanto, Peres (2012) observou a falta de interlocução do Plano de Bacia com os Planos Diretores (determinantes das diretrizes para o planejamento e gestão do território municipal), dado que os instrumentos deste Planos não miram os mesmos os mesmos objetivos; as unidades de planejamento e gestão são diferentes (bacia hidrográfica e limites políticos-administrativos). O Plano de Bacia, apesar de ser considerado um instrumento de referência, ainda encontra dificuldades para uma implementação mais efetiva e, conforme a autora, trata-se de uma peça excessivamente técnica e pouco incorporada no cotidiano das instâncias de gestão. Contudo, uma vez superadas estas dificuldades haveria muitos ganhos relativos à articulação do planejamento urbano à dimensão ambiental, bem como às dimensões sociais, culturais e política, algumas das dimensões vinculadas a paisagem.

Uma tentativa de aproximar a gestão da água com a gestão do uso do solo foi a reestruturação institucional do Ministério do Meio Ambiente em 2007, com a transformação da antiga Secretaria de Recursos Hídricos em Secretaria de Recursos Hídricos e Ambiente Urbano (SRHU). Criada pelo Decreto no 6.101/2007, a SRHU e suas ações deveriam ter a água como elemento gerador e integrador, fundamentando-se na integração de políticas, na sustentabilidade socioambiental, bem como no controle e na participação social (PERES, 2012).

\section{A bacia hidrográfica como unidade de planejamento do território}

O Plano de Bacia Hidrográfica, que tem como unidade territorial de planejamento e gestão a bacia hidrográfica - unidade endossada pela 'Agenda $21^{\prime 87}$, na direção do desenvolvimento sustentável -, foi um grande avanço quanto à potencial integração entre as abordagens urbana e ambiental. A bacia hidrográfica foi definida, no campo ambiental, como

\footnotetext{
${ }^{87} \mathrm{Na}$ Agenda 21, o Capítulo 18, que tratou da 'Proteção da qualidade e do abastecimento dos recursos hídricos: aplicação de critérios integrados no desenvolvimento, manejo e uso dos recursos hídricos', colocou como um de seus objetivos "o manejo integrado dos recursos hídricos; inclusive a integração de aspectos relacionados terra e à água, deve ser feito ao nível de bacia ou sub bacia de captação" (CNUMAD, 1995).
} 
área de drenagem de um rio principal e de seus tributários que confluem até resultar em um leito, chegando em um lago ou oceano. Porto e Porto (2008) apresentaram a seguinte definição:

Sobre o território definido como bacia hidrográfica é que se desenvolvem as atividades humanas. Todas as áreas urbanas, industriais, agrícolas ou de preservação fazem parte de alguma bacia hidrográfica. Pode-se dizer que, no seu exutório, estarão representados todos os processos que fazem parte do seu sistema. $O$ que ali ocorre é consequência das formas de ocupação do território e da utilização das águas que para ali convergem (PORTO; PORTO, 2008, p. 45).

A bacia hidrográfica é uma escala de investigação antiga no campo da geografia (CUNHA; COELHO apud PERES, 2012), considerada uma unidade natural de pesquisa, que inicialmente centralizava-se na solução de questões relacionadas à irrigação, navegação e abastecimento, mas teve sua definição ampliada para incluir aspectos relacionados aos usos múltiplos da água e aos conflitos decorrentes desse uso.

As implicações sobre o uso dos recursos hídricos provêm de uma série de fatores naturais, econômicos, sociais e políticos, sendo o recurso "água" tão somente o ponto de convergência de um complexo sistema ambiental (PIRES et al, 2002, p. 18).

Nessa perspectiva, as origens do planejamento por bacias hidrográficas no Brasil remontam à referência da Comissão Interestadual da Bacia Paraná-Uruguai (CIBPU) na década de 1950. A CIBPU trouxe a pauta do planejamento regional por bacias hidrográficas ${ }^{88}$, tomando como tema central o "domínio das águas" e buscando a articulação do desenvolvimento econômico com o melhor aproveitamento dos recursos hídricos para navegação e produção de energia elétrica. Seus amplos diagnósticos incluíam temáticas relacionadas aos aspectos econômicos, ao meio físico e às questões sociais (CHIQUITO, 2011).

Segundo Chiquito (2011), a CIBPU foi uma experiência pioneira de planejamento no país que produziu vários estudos relacionados ao desenvolvimento regional e articulou governo e empresas de consultoria nacionais e internacionais, sendo também responsável

\footnotetext{
${ }^{88} \mathrm{~A}$ CIBPU teve como referência a modelo de planejamento regional norte-americano do Tennessee Valley Autorithy (TVA) (1933), uma autarquia federal com a função planejar e coordenar os diversos projetos setoriais de uso múltiplo e integral dos rios da bacia hidrográfica do rio Tennessee, envolvendo sete estados. Esta proposta visava gerir a navegação, controlar as cheias, a erosão e o reflorestamento das áreas ribeirinhas, pretendia também administrar o desenvolvimento agrícola, industrial e a geração de energia, além de promover a valorização da terra e a criação de núcleos urbanos (CHIQUITO, 2011). Em 1942, o governo norte-americano enviou ao Brasil uma missão, sob o comando de Cooke, que realizaria um diagnóstico acerca do desenvolvimento econômico do país, tendo como base o modelo de planejamento do TVA.
} 
pela formação de técnicos e planejadores e, ainda assim, teve pouca visibilidade na historiografia do urbanismo brasileiro.

Outro ponto cego na historiografia do planejamento se refere à concepção de planejamento de bacias hidrográficas, que vem ganhando força, recentemente, a partir de seus vínculos com a questão ambiental e que aparece como sendo uma novidade e um consenso em relação à dimensão de sustentabilidade do desenvolvimento. Nesta perspectiva, a compreensão das experiências de planejamento de bacias hidrográficas, como é o caso da CIBPU, pela historiografia é de grande relevância, não com o objetivo comparativo com as experiências recentes, mas como uma busca de conceitos que talvez tenham se perdido no decurso do tempo. (CHIQUITO, 2011, p. 19).

Ressalta-se que a bacia hidrográfica é uma unidade de planejamento sobre a qual se fundam os processos de compreensão dos territórios desde a origem do campo disciplinar da Arquitetura da Paisagem, vide Olmsted e McHarg.

Porto e Porto (2008) entenderam que a Política Nacional de Recursos Hídricos permitiu que as bacias, na forma de unidades de gestão, fossem determinadas conforme a escala e as características da problemática em questão.

A questão da escala a ser utilizada depende do problema a ser solucionado. Pode ser delimitada a totalidade da bacia do Rio Amazonas, desde suas cabeceiras mais distantes na cordilheira andina até seu exutório do Oceano Atlântico, assim como podem ser delimitadas suas sub bacias, maiores ou menores, dependendo da necessidade do problema a ser abordado. Diz-se que o tamanho ideal de bacia hidrográfica é aquele que incorpora toda a problemática de interesse (PORTO; PORTO, 2008, p. 45)

É na escala municipal que as decisões sobre o planejamento do uso e ocupação do solo acontecem, embora o município atue principalmente no ordenamento territorial, ele tem papel relevante na gestão dos recursos hídricos, pois as ações sobre o território influenciam diretamente na qualidade das águas. Portanto, no presente estudo, a bacia hidrográfica é unidade de leitura e planejamento da paisagem, utilizada na investigação dos espaços livres do território na escala da mancha urbana. Nesse sentido, o Sistema de Espaços Livres se coloca como nova maneira de planejamento do território, tentando estabelecer permeabilidades entre as lógicas urbanas e ambientais e agregando à elas outras dimensões que são intrínsecas à paisagem. 


\section{SÃO CARLOS E SEU PROCESSO DE URBANIZAÇÃO: DESENVOLVIMENTO, CONFLITOS E PLANEJAMENTO}

Localizada na região central do estado de São Paulo, à 247 km de distância da capital, a cidade de São Carlos foi escolhida para análise, objetivando a proposição de um Sistema de Espaços Livres. Com uma população estimada de 251.983 habitantes ${ }^{89}$ (IBGE, 2019), da qual a maioria vive no perímetro urbano que corresponde aproximadamente à área de $80,47 \mathrm{~km}^{2}$ (SÃO CARLOS, 2016), representando apenas 7,07\% do território Municipal $(1.136,907$ km²) (IBGE, 2019). Deste modo, a cidade configura-se em meio a uma extensa área rural (figura 24) pressionada pela expansão urbana, que é caracterizada pelo espraiamento e pela especulação imobiliária (SCHENK; PERES, 2014). O avanço da periferia em direção a áreas rurais e áreas de mananciais de abastecimento de água ao mesmo tempo provocou a dispersão da cidade e proporcionou o surgimento de espaços livres na malha urbana, fruto de escolhas de planejamento que desconsideraram as dinâmicas naturais.

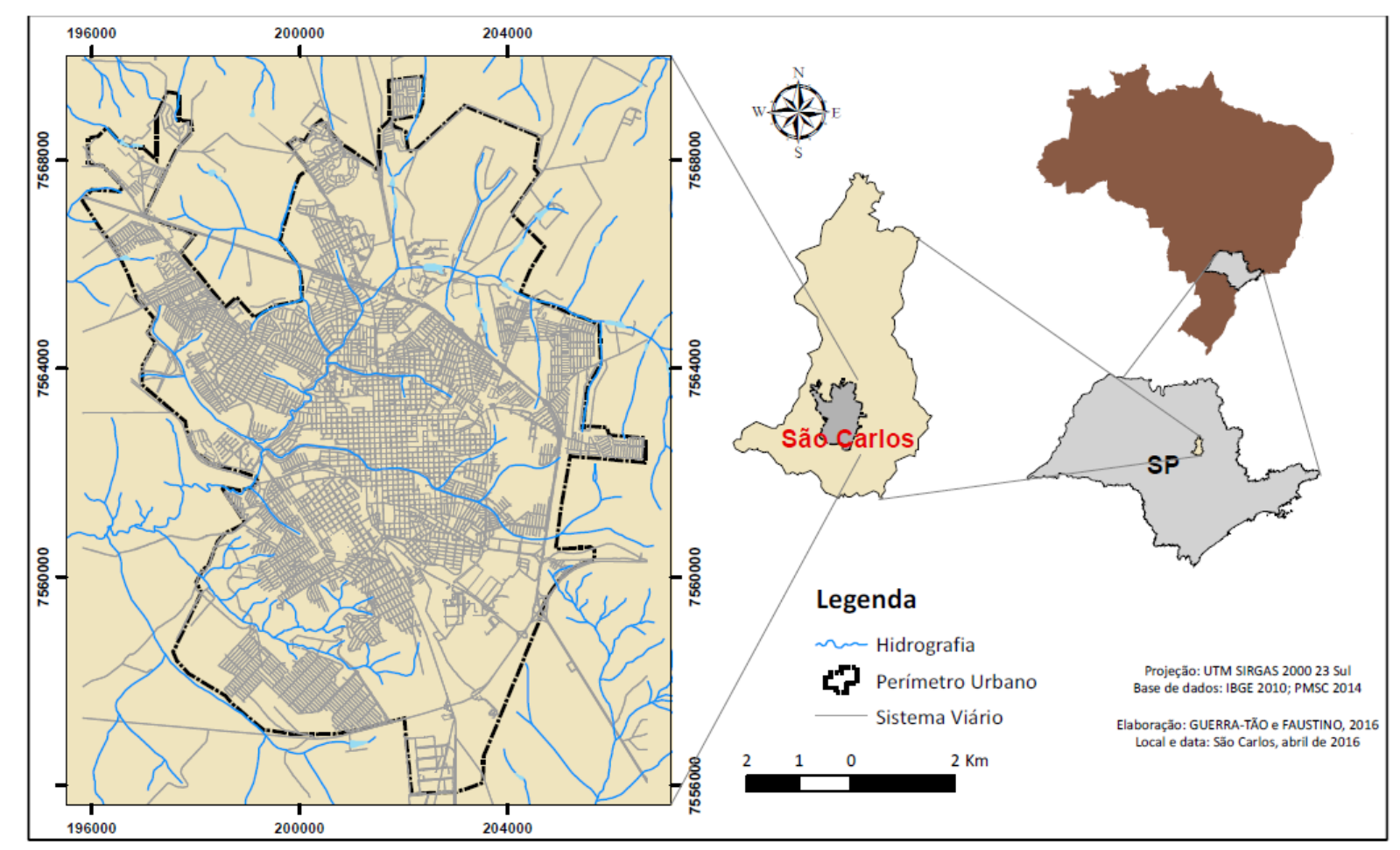

Figura 24: Localização e perímetro urbano do município de São Carlos, SP. Fonte: FAUSTINO et al., 2016.

\footnotetext{
${ }^{89}$ População estimada pelo IBGE em 2019. População do censo de 2010: 221.950 pessoas (IBGE, 2010).
} 
A região com altitude média entre 700 e 900 metros, expressos em uma paisagem singular com grandes declividades, possui fragmentos de vegetação significativos e áreas de turismo ecológico como a Área de Proteção Ambiental Corumbataí, a Represa do Broa e Estações Ecológicas. Situa-se no divisor de águas entre as bacias dos rios Tietê-Jacaré e MogiGrande e sobre o Aquífero Guarani, e apresenta extensa rede hídrica com diversos córregos e nascentes (figura 25).

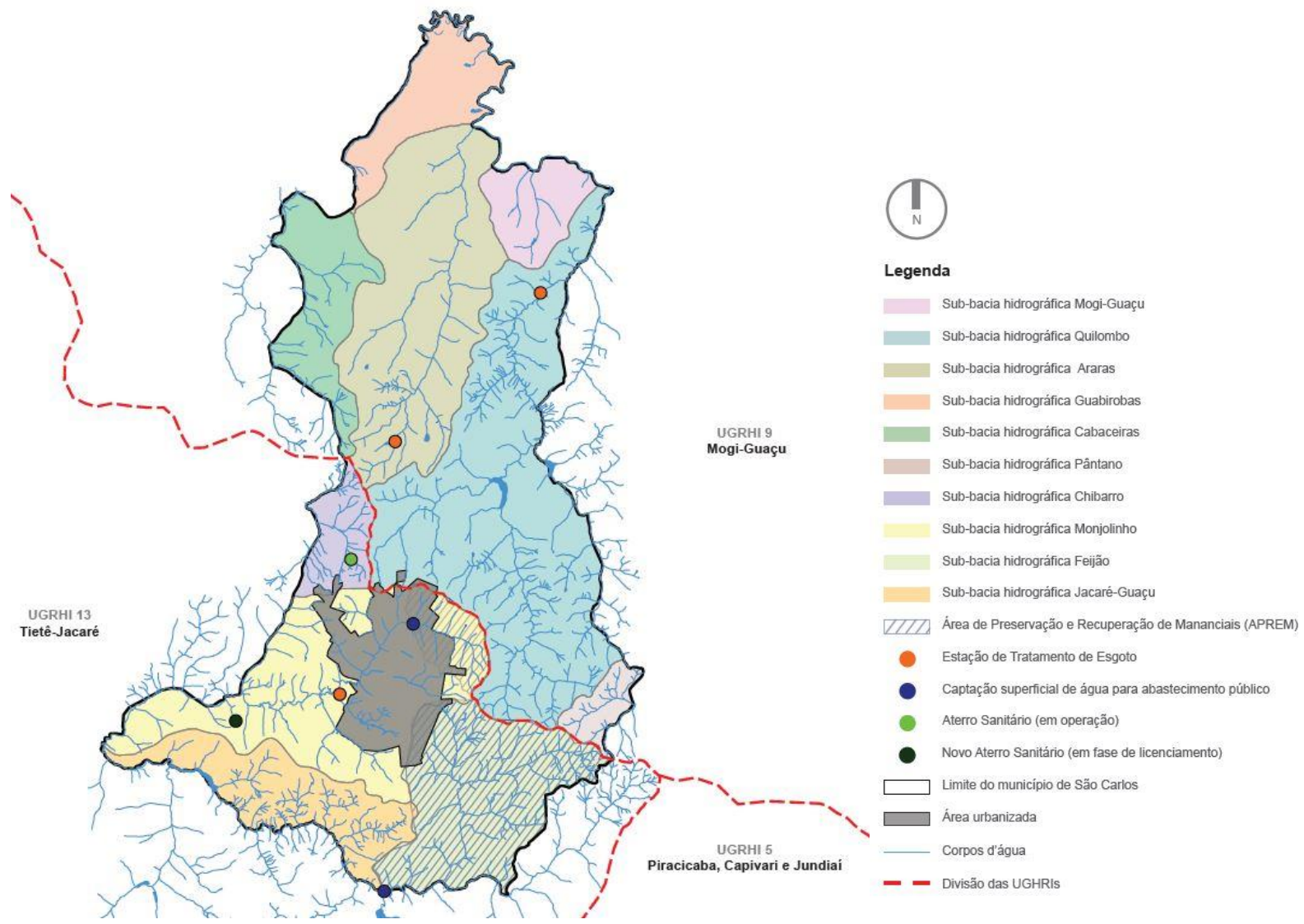

Figura 25: Mapa de localização do município de São Carlos quanto as bacias hidrográficas. Fonte: Adaptado de SÃO CARLOS/FUSP, 2011.

A maior parte da área urbana se inscreve na sub bacia hidrográfica do Monjolinho (figura 26), constituída por uma rede hídrica em que diversos córregos desaguam neste rio que percorre toda a cidade e conforma parte de seus espaços livres. Esta rede encontra-se em boa parte canalizada e com avenidas marginais implantadas na maior parte de suas margens. 


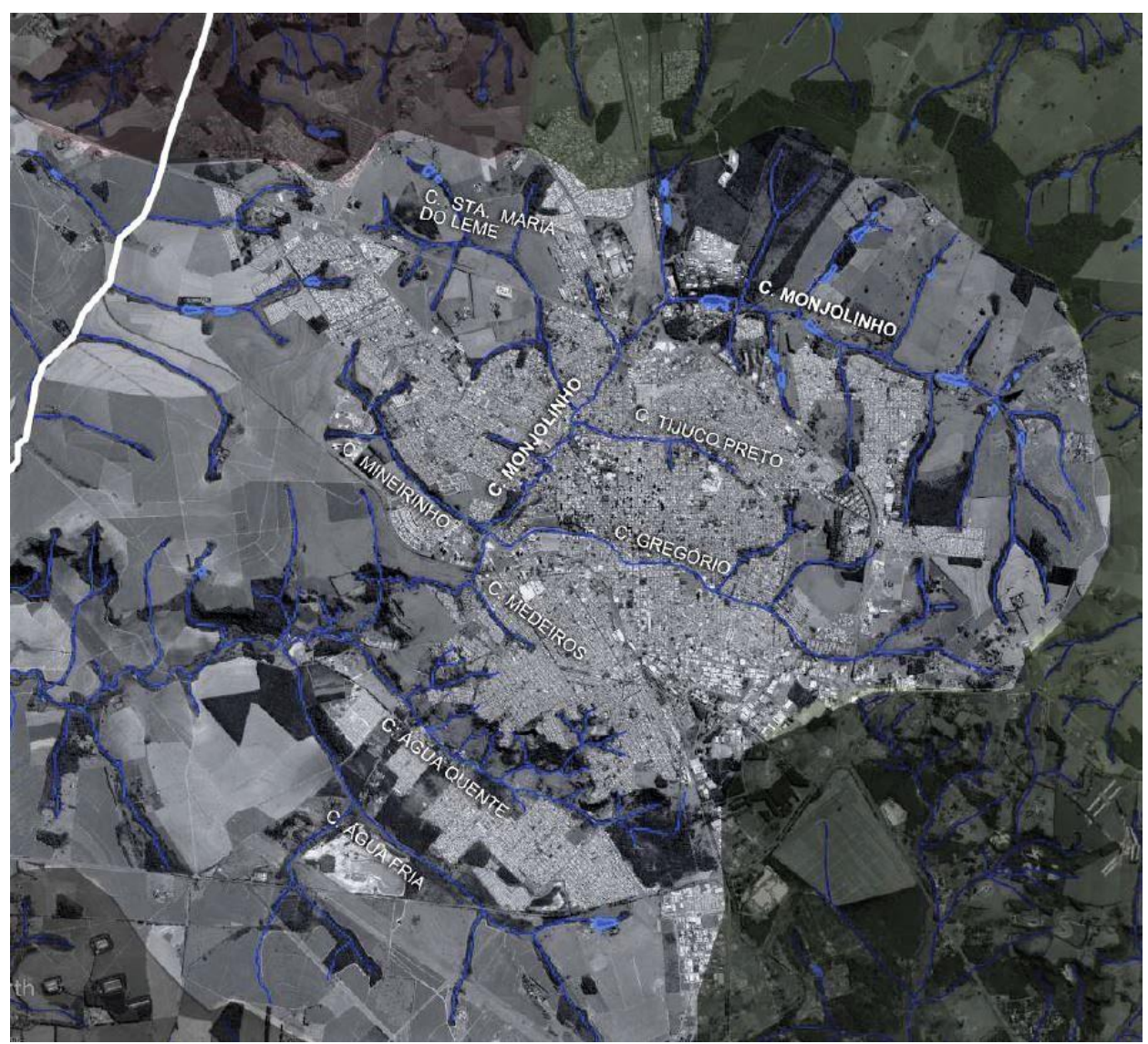

Figura 26: Principais córregos da sub bacia hidrográfica do córrego Monjolinho. Fonte: LIMA, 2019, p. 105.

Geograficamente a cidade está próxima a importantes rodovias, como a rodovia Washington Luiz e a rodovia Eng. Thales de Lorena Peixoto Júnior, sendo também atravessada pela ferrovia, o que facilita os deslocamentos e o escoamento da produção. A maior representatividade da economia do município é do setor de comércio e serviços e da indústria, principalmente do setor de material elétrico-comunicações e mecânico-metalúrgico. A presença de indústrias e empresas voltadas para o desenvolvimento tecnológico é um grande diferencial do município e isso se soma à presença de duas universidades públicas, a Universidade de São Paulo (USP) e a Universidade Federal de São Carlos (UFSCar), e centros de pesquisa como a EMBRAPA. 


\subsection{A construção do conflito entre o desenvolvimento urbano e o meio físico e a formação dos espaços livres}

\section{Conformação da malha urbana de São Carlos}

Para compreender o conflito entre o desenvolvimento urbano e o meio físico, bem como a formação dos espaços livres neste território, resgatou-se a história de constituição da cidade pela periodização estabelecida por Lima (2007). Em sua dissertação sobre a expansão urbana de São Carlos esta autora identificou três grandes períodos históricos - 1857 a 1929; 1930 a 1959, e 1960 a 1977 - referentes à interação entre desenvolvimento econômico, características físico-territoriais no processo de urbanização e estratégias de controle sobre o espaço urbano, com especial foco na estruturação administrativa do setor de planejamento da administração municipal.

A origem da cidade está ligada ao caminho conhecido como Picadão de Cuiabá, estrada que no final do século XVIII passava pelos Sertões de Araraquara e escoava a produção de minérios da região dos atuais Estados de Goiás e Minas Gerais até o litoral. No encontro do Picadão com o córrego Gregório, local de embarque e desembarque dos viajantes, o povoamento começou a se formar a partir do fornecimento de pouso e de abastecimento, proporcionado pelos pequenos estabelecimentos pecuários e agrícolas ali instalados (DEVESCOVI, 1985). A região, onde originalmente havia amplos bosques naturais de pinheiros de araucária, fato que determinou o nome inicial da cidade, São Carlos do Pinhal, foi ocupada através da concessão de sesmarias, sobretudo para a família Botelho, e pela ação de posseiros e posteriormente pela comercialização de terras (LIMA, 2007).

A consolidação do núcleo urbano está atrelada ao avanço da lavoura cafeeira, que se tornou a principal atividade da região em 1886, no âmbito de interiorização da produção do café no Estado (DEVESCOVI, 1985).

O primeiro período delimitado por Lima (2007) tem início em 1857, ano de conclusão da capela (no local da atual Catedral de São Carlos) e ano em que passou a existir oficialmente o Distrito de Paz de São Carlos do Pinhal90. A cidade crescia em função da economia

\footnotetext{
90 O Distrito de Paz de São Carlos do Pinhal foi criado em 20 de abril de 1857, mas a data oficial de fundação é 4 de novembro de 1857, em homenagem a São Carlos Borromeu, santo italiano padroeiro da cidade (FEITOSA, 2015). O Distrito foi elevado à categoria de Vila em 1865 e, Município em 1880 (DEVESCOVI, 1985).
} 
agroexportadora do Complexo Cafeeiro, apresentando expressiva expansão ${ }^{91}$ da área urbana até 1893, intensificada com a implantação da ferrovia em 1884 e vinda de imigrantes para trabalhar na lavoura entre o final do século XIX e início do século XX. O pequeno povoado avançou do pátio da capela em direção ao norte, subindo a colina, através da doação de datas $^{92}$ e da comercialização, enquanto ao sul a ferrovia foi fator de atração desse crescimento.

O disciplinamento do território era de responsabilidade da Câmara e da Igreja Católica, que utilizavam os Códigos de Posturas (dos anos de 1866, 1880, 1888, 1905, 1929) sob influência dos modelos portugueses, e que definiram o traçado homogêneo e ortogonal do arruamento (figura 27). Assim o núcleo urbano se expandiu a partir do primeiro eixo viário no sentido Norte-Sul (atual Av. São Carlos), seguindo a configuração em grelha que predominou até 1929. Os Códigos de Posturas definiam as regras para a construção das ruas, o alinhamento das edificações, o tamanho dos terrenos, e delimitavam o perímetro urbano e as condições para concessão de datas.

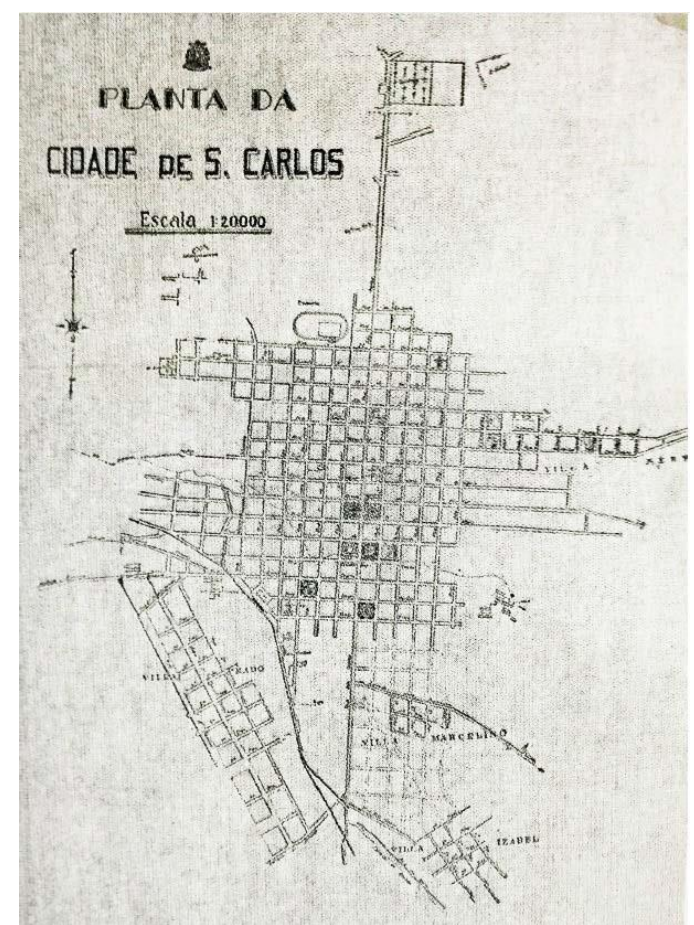

Figura 27: Uma das primeiras cartografias de São Carlos.

Fonte: Fundação Pró-Memória, sem data.

\footnotetext{
${ }^{91} \mathrm{Em}$ 1888, a área urbana de São Carlos era 247 hectares, passou para 364 hectares em 1893 (crescimento de 47,37\%) (LIMA, 2007), enquanto a população urbana em 1891 era 5000 habitantes, passou para 8000 habitantes em 1894 (DEVESCOVI, 1985).

92 "Pequenas porções de terra que serviam para a construção dos edifícios" (LIMA, 2007, p. 39).
} 
A ferrovia não só impulsionou a economia cafeeira como também teve papel determinante na expansão do território urbano, atraindo loteamentos para suas proximidades, local de moradia dos operários, ferroviários e pequenos comerciantes. Ela foi implantada ao sul da capela, do lado esquerdo da margem do córrego Gregório, e construída a meia encosta para obter uma declividade máxima compatível com os padrões técnicos, cortando o território em diagonal com relação ao traçado urbano ortogonal (ANELLI, 2007). A malha urbana estendeu-se pelo fundo de vale (figura 28), transpondo o córrego em direção à estação ferroviária. O formato dos quarteirões foi adaptado à inflexão da ferrovia e os novos bairros localizados do outro lado dos trilhos acompanharam essa inflexão. Lima (2007) observou já nesse momento a presença de segregação socioespacial, pois a elite oligárquica, a emergente classe de comerciantes e os proprietários de fábricas ocupavam a área central no entorno da capela, enquanto a classe trabalhadora residia na várzea do córrego e na periferia, nas imediações da ferrovia.

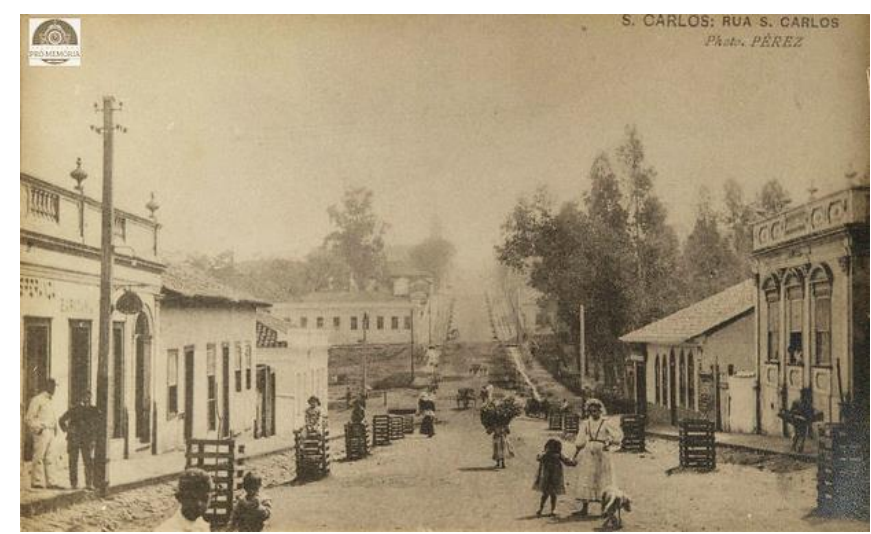

Figura 28: Rua São Carlos (atual avenida São Carlos) atravessando o córrego Gregório. Fonte: Fundação Pró-Memória de São Carlos, 1866.

A paisagem urbana desse período era composta por edificações alinhadas à testada do terreno, ruas e passeios amplos, de traçado homogêneo e com ínfima arborização, em oposição ao miolo das quadras, formado pelas áreas não construídas dos fundos de lotes, que eram bem arborizados, situação ainda possível de se encontrar em algumas quadras do centro da cidade. Quanto aos espaços públicos verdejados da cidade, destaca-se a inauguração do Jardim Público no Pátio da Catedral em 1895 (LIMA, 2007), que pertence ao primeiro conjunto 
de praças localizados no eixo Norte-Sul da Rua São Carlos (atual avenida São Carlos) (Figura 29).

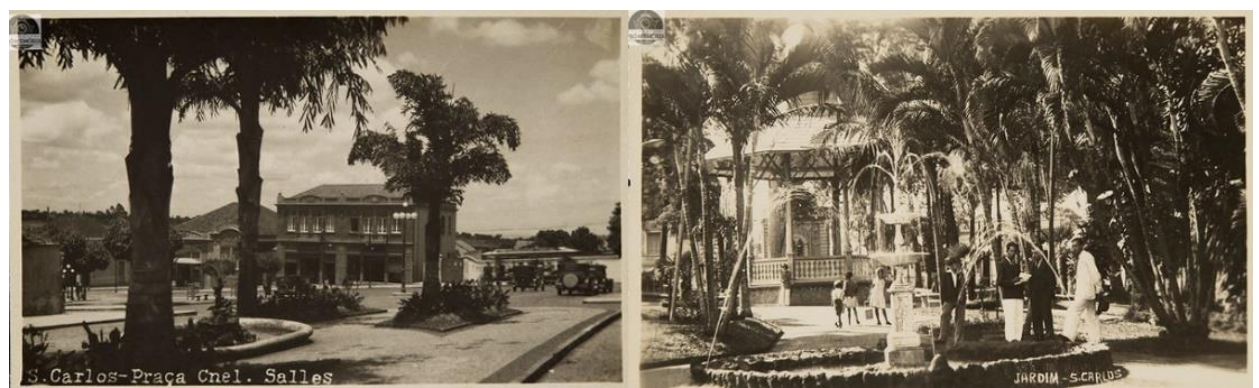

Figura 29: Praças na avenida São Carlos na década de 1940: Coronel Salles à esquerda e Jardim Público à direita.

Fonte: Fundação Pró-Memória de São Carlos.

O planejamento urbano deste período começou a ocupar áreas impróprias, como as margens de córregos, marcando o surgimento do conflito entre o ambiente natural e o ambiente construído. Em 1899 já é possível encontrar notícias em jornais sobre enchentes na região dos córregos Gregório e do Simeão (LIMA, 2019).

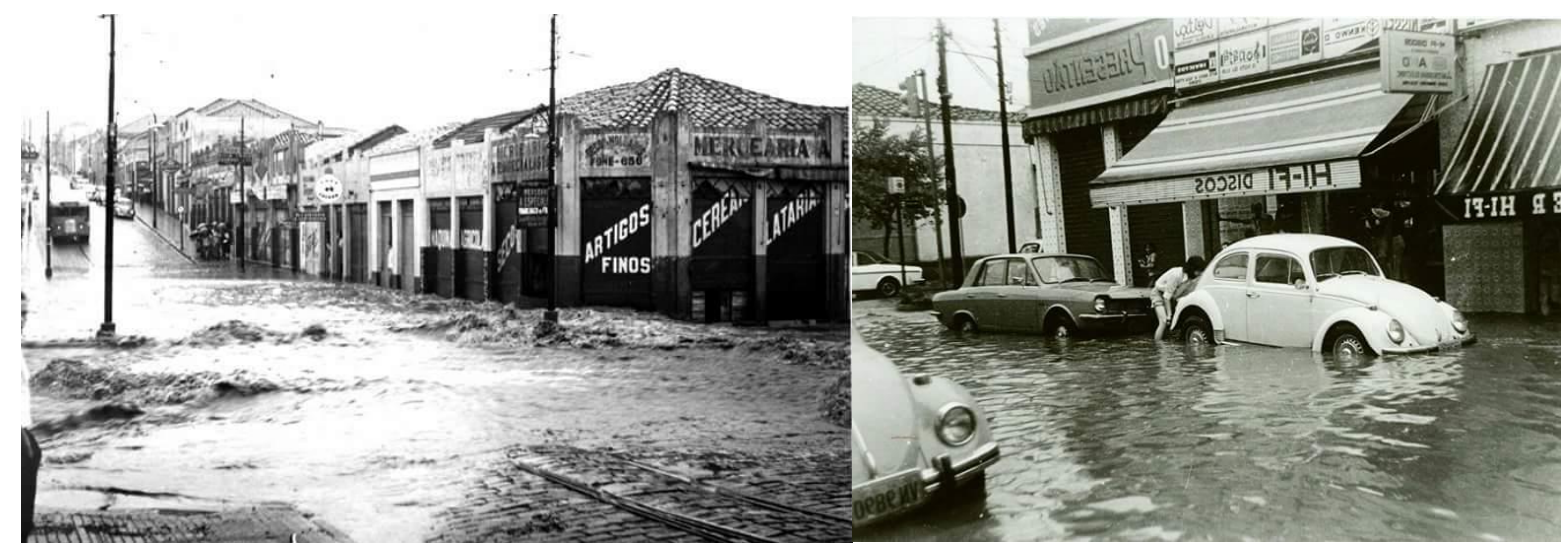

Figura 30: Enchentes na área central de São Carlos.

Fonte: Fundação Pró-Memória de São Carlos.

Entre 1894 e 1929, a expansão urbana foi menos acentuada, porém houve acréscimo populacional urbano ${ }^{93}$ devido à migração campo-cidade que se iniciava. Enquanto a área central começava a se adensar, na periferia começavam a surgir loteamentos espontâneos

\footnotetext{
${ }^{93} \mathrm{Em} 1894$ a população era 8.000 habitantes, passou para 17.000 habitantes em 1926 (DEVESCOVI, 1985). Entre 1894 e 1929, apenas um novo loteamento foi implantado (LIMA, 2007).
} 
adjacentes à ferrovia e junto às primeiras indústrias, impulsionados também pela facilidade do transporte por bondes elétricos em circulação desde 1914.

No final do século XIX, aproveitando o impulso econômico gerado pela produção cafeeira, parte do capital excedente produzido foi investido em infraestrutura, como redes de transporte por bondes, telefonia, coleta de esgoto, abastecimento de água e também no setor imobiliário e comercial (construção de edifícios - Câmara Municipal, Teatro, Santa Casa, bancos, escolas), de modo que a cidade passou por grandes transformações e expansão urbana. Devescovi (1985) assinalou que no início do século XX a cidade já apresentava um ambiente construído apropriado para adentrar ao próximo ciclo econômico com base na produção e consumo interno.

\section{O espraiamento da cidade e a formação dos espaços livres}

O segundo período se inicia em 1930, posteriormente a elaboração do Código de Posturas de 1929 que passou a permitir a diversificação do traçado do arruamento, desobrigando o seguimento da morfologia inicial. Este Código foi concebido pela Câmara Municipal e incorporou os paradigmas relacionados à modernização do país quanto ao progresso e a eficiência urbana, que se refletiram em novos parâmetros urbanísticos para prolongamento e abertura de ruas, bem como na estrutura administrativa do município. As mudanças na estrutura administrativa referiam-se à centralização do poder executivo na figura do prefeito municipal, que adquiriu responsabilidade pela aprovação dos novos parcelamentos. Lima (2007) apontou que o Código de 1929 almejava um controle maior sobre o espaço urbano ao propor a aprovação dos novos parcelamentos pela Prefeitura, assim como ao definir parâmetros de uso e ocupação do solo e ao designar áreas de uso restrito. Entretanto, na prática esse controle não ocorreu devido à inexistência de um plano geral de arruamentos que orientasse seu desenho.

Em âmbito nacional, a partir da década de 1930, o desenvolvimento industrial foi intensificado em função do investimento do governo Getúlio Vargas, através da substituição de importações, principalmente de bens de consumo, fato que também se relacionava à grande crise internacional do café. Em São Carlos, que teve precoce industrialização (SCHENK, PERES, FANTIN, 2015), foi ocorrendo a diversificação do setor fabril, que antes visava à 
complementação da atividade cafeeira e, também das atividades agrícolas, com destaque para a produção de algodão e, posteriormente, a ascensão e substituição das lavouras pela pecuária (leite e laticínios) (DEVESCOVI, 1985).

No final da década 1940 foi definida a vocação industrial ${ }^{94}$ do município, voltada para a produção de materiais mecânicos e elétricos em virtude da implantação da Escola de Engenharia de São Carlos da Universidade de São Paulo ${ }^{95}$ (EESC-USP) com os cursos de Engenharia Mecânica e Engenharia Elétrica. Foi nesse período que a população urbana teve seu crescimento impulsionado pelo aumento do êxodo rural devido à queda da produção cafeeira e à produção industrial em ascensão, ultrapassando a população rural, calculando-se em 1940 uma taxa de urbanização de 52,30\% (LIMA, 2007). Os migrantes vieram atraídos pela oportunidade de emprego na cidade, gerando a demanda por novas moradias que foram construídas em proximidade aos locais de trabalho, isto é, as indústrias, intensificando-se o processo de espacialização da habitação popular que se iniciou no período anterior. Como apontou Feitosa (2015, p. 103) em seu estudo sobre a relação entre industrialização e urbanização em São Carlos:

Até 1948, todos os loteamentos foram implantados próximos às indústrias e, embora não fossem exclusivamente destinados aos operários, a maioria das moradias eram destinadas a essa classe. Portanto, se o processo de industrialização impõe um ritmo e uma lógica à urbanização, o período de 1935 a 1948 pode ser considerado como paradigmático em São Carlos. Os 106,63 hectares de loteamentos implantados nesse período se localizaram ao redor das concentrações industriais, sendo que a localização das indústrias e demais atividades econômicas se concentraram próximas à estação ferroviária, em área bem servida pelo bonde elétrico, ou seja, a localização do transporte sobre trilhos determinou a localização das atividades econômicas que, por sua vez, determinou a localização dos loteamentos e das moradias.

Com a consolidação da economia industrial em São Carlos e a consequente mudança na representação política do município pelos setores mais significativos dessa economia (industriais, comerciantes e a nascente classe média), a agenda do poder público se direcionou

\footnotetext{
${ }^{94}$ Feitosa (2015, p. 75-76) apontou que, entre 1930 e 1948, São Carlos teve expressivo crescimento industrial de $86 \%$, e os setores de maior ampliação foram os dos ramos mobiliário (287\%), o de metal-mecânica (137\%) e o de vestuário (102\%), produtos voltados ao mercado interno.

95 A EESC começou a ser idealizada na década de 1940, sendo criada pela Lei no 161/1948 e efetivamente instalada em 1952. Fonte: EESC/USP. Disponível em:

<http://www.eesc.usp.br/portaleesc/index.php?option=com_content\&view=article\&id=33\&ltemid=219>. Acesso em: 17 ago. 2018.
} 
para atender as necessidades de lucro desses setores. Os industriais e comerciantes eram os principais empreendedores de loteamentos, atuando tanto na política quanto na aplicação de seu capital no ramo imobiliário, assim a legislação urbanística ${ }^{96}$ foi flexibilizada no sentido de atender os interesses especulativos desses empreendedores (FEITOSA, 2015).

Seguindo a lógica racional do aproveitamento do espaço atrelado ao lucro, muitos parcelamentos construídos a partir da década de 1940 apresentavam um novo desenho de quadra, mais comprida e menos profunda para acomodar um maior número lotes, com área de $300 \mathrm{~m}^{2}$, medida inferior ao lote padrão $\left(750 \mathrm{~m}^{2}\right)$ utilizado desde o século XIX. Lima (2007) apontou os muitos casos em que os empreendedores não executavam as áreas públicas de forma adequada e às vezes nem mesmo a infraestrutura, sendo esses gastos assumidos pelo poder público ou pelos próprios moradores. Um exemplo emblemático foi a construção do loteamento Cruzeiro do Sul em 1954, que possuía 1605 lotes sem uma única área verde ou institucional (LIMA, 2007). Os loteadores usaram a autonomia, garantida por lei federal e registrada em contratos (conforme nota 96), para estabelecer parâmetros urbanísticos, estipulando cláusulas específicas para cada loteamento, o que também acabou determinando o padrão socioeconômico de cada área. O traçado urbano diversificou-se, ficando a cargo do loteador ou do profissional por ele contratado.

Deste modo, observou-se que as classes média e alta habitavam a área central ou bairros bem servidos de infraestrutura (Jardim Santa Paula, Cidade Jardim ${ }^{97}$, Vila Pureza, Vila Elizabeth entre outros), enquanto as classes baixas habitavam a periferia (Jardim Pacaembu, Vila Derigge, Jardim Bandeirantes, Vila Jacobucci, Vila São José, Vila Leonardo), muitas vezes sem acessibilidade adequada e sem infraestrutura. Os projetos dos novos parcelamentos passavam pela aprovação na prefeitura e deveriam estar de acordo com as diretrizes

\footnotetext{
${ }^{96}$ Além do Código de Posturas de 1929, a Prefeitura aprovou a Lei de Habitação (Lei no 1004/1948) para facilitar a construção de habitações econômicas, com diminuição das exigências mínimas para a construção de moradia urbana. Outras leis contribuíram para o descontrole da expansão urbana, como a primeira lei exclusiva para delimitação do perímetro urbano (criada pelo Decreto Municipal no 540/1940) e o Decreto-lei Federal no 58/1937, que dispunha sobre loteamentos e venda de terrenos pagos em prestações, colocando a obrigatoriedade dos contratos de serem registrados em cartório. No entanto, este Decreto-lei Federal não tratava a respeito das dimensões do parcelamento e outros parâmetros urbanísticos ou diretrizes de expansão urbana, o que abriu precedência para a atuação arbitrária dos loteadores. Na prática os contratos estabeleciam parâmetros específicos para cada parcelamento elaborados a serviço do empreendedor, e que não podiam ser modificados pela lei municipal (LIMA, 2007).

${ }^{97}$ Um dos bairros de classe média implantados no entorno da USP em 1954, que apesar do nome, não apresenta características urbanísticas da Garden City proposta por Ebenezer Howard.
} 
urbanísticas da cidade, que, no entanto, eram imprecisas e pouco exigentes, resultando em diversidade no desenho urbano (LIMA, 2007).

A partir da década de 1950, a ferrovia deixou de ser fator determinante para localização das indústrias, a cidade se expandiu para novos eixos de circulação, influenciados pela construção das rodovias ${ }^{98}$ São Carlos - Araraquara e São Carlos - Rio Claro (mais tarde nomeada Washington Luís) e pelo crescimento do setor automobilístico. Além disso, o transporte intraurbano por ônibus passou a funcionar em 1951, contribuindo para a dispersão dos loteamentos pela periferia.

Nesse período o perímetro urbano aumentou ${ }^{99}$ consideravelmente para incluir os novos loteamentos periféricos que avançavam para a zona rural, constituindo um desenvolvimento urbano espraiado, caracterizado pela descontinuidade com a malha urbana preexistente, que resultou na formação de espaços livres pouco qualificados em termos de projeto.

\footnotetext{
${ }^{98} \mathrm{O}$ processo de industrialização das cidades paulista do interior do Estado, foi dinamizado pela estruturação da rede de conexão estabelecida com a expansão das rodovias entre os anos de 1930 e 1959.

${ }^{99}$ Durante a década de 1950 a expansão ocorreu em todas as direções, sendo realizados 41 novos parcelamentos, consequentemente a área urbana dobrou de tamanho, passando de 650 hectares em 1949 para 1370 hectares em 1959 (LIMA, 2007).
} 


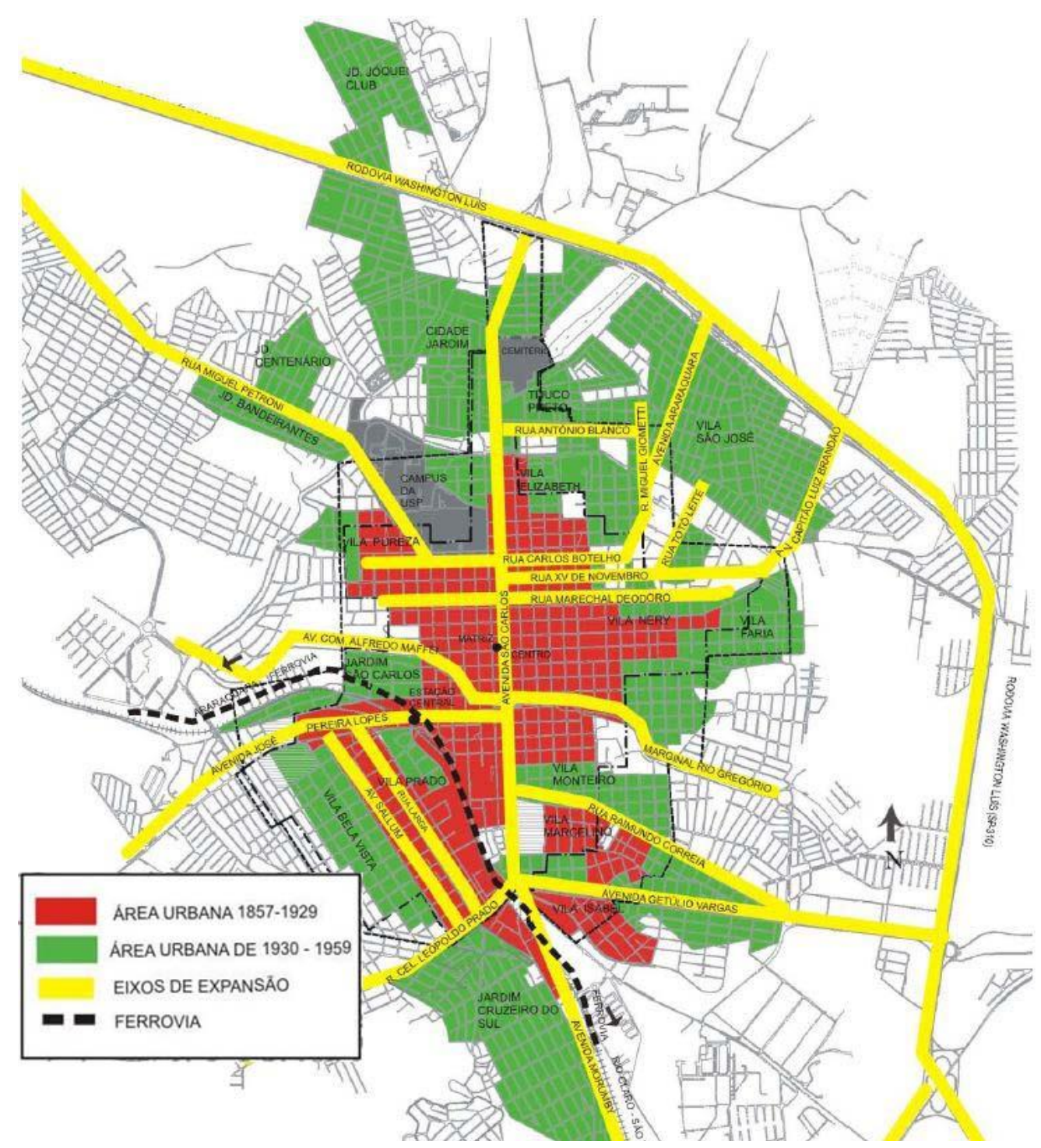

Figura 31: Principais eixos de expansão no período 1930-1959 e crescimento da área urbana. Fonte: LIMA, 2007, p. 86.

\section{A tentativa de controlar a expansão urbana e a implantação das marginais}

O intenso desenvolvimento urbano ocorrido no terceiro período demarcado por Lima (2007), 1960-1977, trouxe uma série de implicações ao cotidiano da sociedade brasileira, que resultaram em novas formas de organização social e espacial. Outras cidades paulistas também passavam por intensa urbanização ligada ao processo de industrialização e alteração nos modos de produção rural. Esse processo implicaria em maior controle pelo governo do Estado do território urbano.

Já na década de 1950, no contexto de constituição de instituições prestadoras de assistência técnica aos municípios para elaboração de planos diretores como o Centro de 
Pesquisas e Estudos Urbanísticos (CPEU), iniciou-se a estruturação do setor de planejamento urbano em São Carlos. Foram criados órgãos auxiliares e novas repartições, sem, contudo, criar-se um departamento específico de planejamento urbano, função exercida pela secretaria de obras e a cargo de engenheiros.

O processo de institucionalização do planejamento urbano na administração municipal em São Carlos começou em 1959 com a formação da Comissão do Plano Diretor para elaborar o primeiro plano diretor da cidade, sob o suporte técnico do CPEU. Além disso, em 1960 foi instituído o Escritório Técnico do Plano Diretor de São Carlos, um órgão de assessoramento diretamente ligado ao Gabinete do Prefeito, numa referência ao modelo norte-americano de administração municipal, tendência na administração brasileira nesse período. O Escritório deveria incluir representantes da prefeitura e da comunidade e seria assistido por um arquiteto urbanista, que pela primeira vez integraria o quadro de funcionários da prefeitura, porém sem direito a voto (LIMA, 2007).

Para elaboração do plano, foram realizados levantamentos e pesquisas sobre diversos aspectos da cidade - históricos, físicos, demográficos, administrativos, financeiros, sociais, culturais, aspectos legais -, que produziram um detalhado diagnóstico sobre os problemas urbanísticos. Esse diagnóstico constatou os problemas decorrentes de anos de uma legislação urbanística permissiva e da ação especulativa na produção do espaço, que implicaram em precariedade da infraestrutura urbana, sistema viário descontínuo, vários lotes vazios, falta de áreas verdes e conflitos com o ambiente natural (LIMA, 2007). O Plano Diretor tinha como objetivo o planejamento da cidade para até 140 mil habitantes, através da figura do zoneamento, estratégia clássica para o período. Para tanto, o plano propôs diretrizes abordando os problemas identificados, dentre as quais vale destacar aqueles referentes ao sistema viário e às áreas verdes:

As diretrizes propostas para o sistema viário previam a construção de uma avenida perimetral, circundando as bacias do córrego Gregório e do Tijuco Preto, a implantação de uma rede de avenidas proporcionando a ligação entre os bairros, a realização de obras para passagens em desnível sobre os cruzamentos da rodovia e da ferrovia, a implantação de vias marginais aos cursos d'água e à ferrovia e a hierarquização do sistema viário com a redefinição da largura das ruas. Para o tratamento das áreas livres foi proposta a ampliação do sistema de recreio ${ }^{100}$ a partir das seguintes ações:

\footnotetext{
100 Tendo como referência o Plano Diretor do Município de São Carlos de 1962, Lima (2007, p. 150) explicou que "o sistema de recreio foi definido pela equipe do plano como um conjunto de áreas verdes livres utilizadas para
} 
criação de parques e jardins ao longo das marginais, formação de bosques nos fundos de vale, implantação de um grande lago artificial, construção de praças de esportes, formação de cinturão verde de chácaras entre a área urbana e a rodovia Washington Luís e melhora no aproveitamento das áreas livres dos loteamentos implantados e dos futuros parcelamentos (Plano Diretor do Município de São Carlos, 1962, citado por LIMA, 2007, p. 149-150).

O plano concluído em 1962 não foi aprovado por lei, porém algumas das diretrizes propostas deram origem a primeira lei de loteamentos na cidade (Lei no 4411/1962), que passou a exigir a reserva de áreas públicas nos novos loteamentos, resultando no significativo aumento da quantidade de áreas verdes e institucionais nos novos parcelamentos. Contudo, a lei contribuiu para manutenção da heterogeneidade dos traçados das vias públicas, pois colocava a exigência de adaptação às condições topográficas do terreno, além de flexibilizar o perímetro urbano ${ }^{101}$ (LIMA, 2007).

A ação especulativa dos loteadores continuou ao longo de todo o período 1960-1977, seguindo os padrões anteriores, loteamentos periféricos com infraestrutura precária e acessibilidade prejudicada, voltados para grupos sociais de baixo poder aquisitivo, enquanto os parcelamentos com infraestrutura adequada e valor elevado, destinavam-se aos grupos sociais de maior poder aquisitivo. Na medida em que a economia crescia e o processo de urbanização se intensificava, a segregação socioespacial se aprofundava. Na periferia o número de parcelamentos espontâneos e "regulamentados" aumentava, proporcionando o surgimento de espaços livres entre eles e a malha urbana consolidada e, consequentemente, dando margem para a especulação imobiliária.

No bojo desse processo, uma nova categoria de loteadores surgiu em São Carlos, para atender ao mercado imobiliário da periferia em crescimento. Essa nova categoria era extremamente especulativa e passou a lotear à margem da legislação urbana recém implantada. Nesse duelo entre o controle e o descontrole, o controle municipal entrou com desvantagem, pois, apesar das novas leis, o enfraquecimento dos poderes municipais e estaduais nos anos de ditadura militar deixou o município com dificuldade para exercer seu controle. Como resultado, os loteamentos precários se proliferaram à medida que a população urbana crescia. O coroamento desse processo ocorreu em 1977, com a aprovação da lei municipal 7.821/77, que abriu precedência para a ampliação aleatória do perímetro urbano,

atividades de lazer e recreação, caracterizadas pelo recreio contemplativo, como bosques, lagos, jardins; e pelo recreio ativo, como playgrounds, locais para jogos recreativos, etc."

101 “....] essa lei passou a considerar que a linha de perímetro urbana seria definida por uma distância de 100 metros do último edifício implantado em área servida por pelo menos um tipo de infraestrutura urbana. Com isso, o perímetro tornava-se irrelevante no controle da expansão" (LIMA, 2007, p. 178). 
aumentando ainda mais o poder de ação dos loteadores especulativos (LIMA, 2007, p. 124).

$\mathrm{Na}$ década de 1960, houve um considerável investimento estrangeiro no setor automobilístico nacional, resultando na popularização do automóvel e causando grande impacto para as cidades brasileiras. Em São Carlos o sistema viário precisou ser reestruturado e as vias adquiriram outros traçados e larguras para melhorar os deslocamentos. Em 1962, com a retirada dos bondes, o transporte coletivo passou a ser feito exclusivamente por ônibus, o que também dinamizou o processo de crescimento em direção às periferias devido à possibilidade de a população dependente de transporte público poder morar em regiões distantes do centro (FEITOSA, 2015).

Nos anos 1970, foram construídas avenidas marginais aos córregos Gregório (figura 32), Monjolinho e Tijuco Preto, que colaboraram para a mudança dos eixos de expansão da cidade. A implantação das avenidas marginais foi acompanhada da canalização e em alguns casos do tamponamento dos cursos d'água, solução julgada adequada para a questão viária na época, que posteriormente revelou-se ineficaz. De acordo com Lima (2019), um jornal da época ("A Folha" de 1968) identificou o córrego do Gregório como um obstáculo aos processos urbanos, sendo visto pela população como local desagradável devido ao mau cheiro e às inundações decorrentes da época das chuvas.

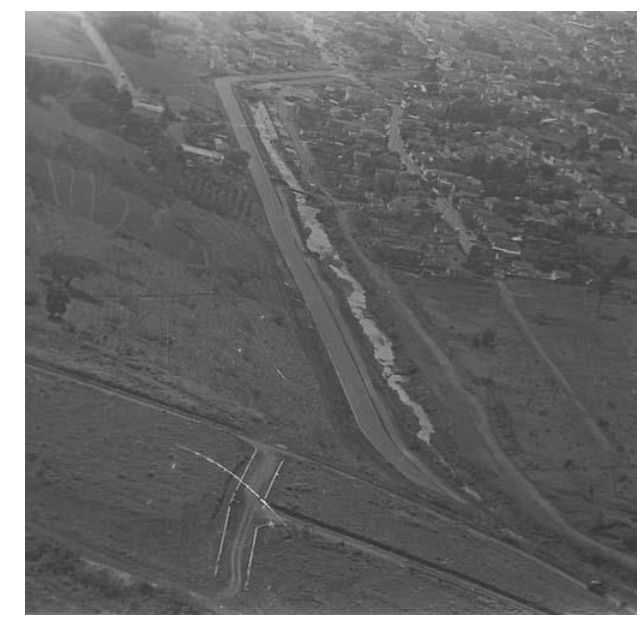

Figura 32: Construção das vias marginais no córrego do Gregório. Fonte: Fundação Pró-Memória de São Carlos, 1974.

As discussões sobre o novo plano diretor entre 1968 e 1970 ocorreram no momento de centralização de poderes pelo Estado na ditadura militar, no contexto do Serviço Federal 
de Habitação e Urbanismo (SERFHAU). O repasse de recursos para as cidades foi determinado pela lei orgânica dos municípios de 1967 e estava condicionado à criação de estruturas administrativas para elaboração do Plano Diretor de Desenvolvimento Integrado (PDDI). Como muitas prefeituras não tinham técnicos capacitados em seus quadros de funcionários, o Estado disponibilizou órgãos de assistência técnica como o Centro de Estudos e Pesquisas de Administração Municipal (CEPAM) e o Instituto Brasileiro de Administração Municipal (IBAM).

Em São Carlos, o PDDI começou a ser elaborado em parceria com a Escola de Engenharia de São Carlos, contando com a assistência técnica do CEPAM e do Instituto Brasileiro de Administração Municipal (IBAM). Mais uma vez foram realizados levantamentos, pesquisas, diagnósticos e propostas diretrizes para habitação, expansão das redes de infraestrutura e controle do crescimento urbano. Em 1971 o PDDI foi aprovado pela lei municipal no 6684/1971 juntamente com as leis de uso e ocupação do solo, a nova lei de loteamentos (Lei no 6808/1971); a lei de edificações (Lei no 6910/1972); a lei de perímetro e zoneamento (Lei no 6878/1972).

Na prática esse arcabouço legislativo reafirmou a autonomia dos loteadores, que se aproveitaram das brechas da legislação, da fiscalização deficiente e das relações de favoritismo para ampliar sua ação especulativa, frustrando os objetivos do plano diretor que almejava o desenvolvimento urbano equilibrado (LIMA, 2007).

Quanto às exigências da Lei Federal de Parcelamento (Lei no 6.766/1979), o impacto nos espaços livres em São Carlos pode ser colocado da seguinte forma:

Em relação aos espaços livres, o que se pode perceber ao observar a Carta da cidade de São Carlos é a constatação daquilo que se tornou lugar comum nas muitas cidades brasileiras submetidas ao processo de desenvolvimento em curso há décadas no país: os espaços contemplados pela Lei no 6.766/79, especialmente os relacionados ao sistema de lazer e recreio, como são chamadas nos documentos da municipalidade, ocupam áreas declivosas, ou tem dimensões, ou inserções urbanas, pouco aproveitáveis em relação a projetos de praças: faixas estreitas, bicos de quarteirões, rotatórias; exceção feita às ruas e avenidas, sistema privilegiado de espaços livres com foco no transporte viário (SCHENK; PERES, 2014).

Deste modo, compreende-se que por mais que houvesse a obrigação de destinação de espaços livres nos loteamentos, a lei federal e a lei municipal não especificavam sua localização e configuração. Essa situação encontraria respaldo no Plano Diretor de 2005 e, 
posteriormente, em regulamentações complementares, em que o Poder Executivo Municipal passaria a definir a localização e configuração destas áreas.

A consolidação comercial e de serviços provocou significativas mudanças de uso e ocupação do solo, principalmente no centro da cidade, área que já se adensava com o início do processo de verticalização na década de 1970 (LIMA, 2007). Foi nessa década também que começaram a surgir os loteamentos de alto padrão fechados, como o Parque Sabará construído em 1976, e as chácaras de recreio implantadas no meio rural nos limites da cidade, utilizadas como lazer para os residentes urbanos, dando continuidade ao processo de espraiamento em descontinuidade com a malha urbana existente.

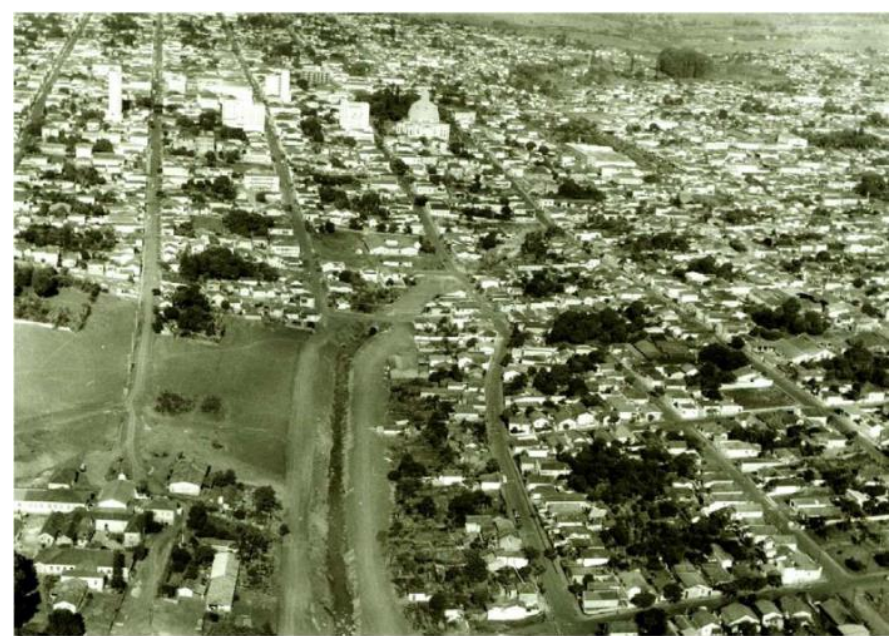

Figura 33: Vista aérea do centro de São Carlos em 1974, onde se observa o Córrego Gregório parcialmente tamponado, os espaços livres, e os primeiros prédios. Fonte: Fundação Pró-Memória.

A imagem acima (Figura 33) retrata bem o cenário descrito até agora. Nota-se o início do processo de verticalização no centro, a arborização nos miolos dos quarteirões (descrito no início do capítulo), os espaços livres no interior da malha urbana e o tamponamento de parte do córrego Gregório.

No contexto nacional, o governo estadual lançou o Programa de Cidades Médias em 1974, seguindo as diretrizes do II Plano Nacional de Desenvolvimento, de criação de polos regionais no interior dos Estados. O objetivo do programa era direcionar a migração das grandes metrópoles para as cidades menores, procurando promover a interiorização da indústria no estado, através de investimentos em cidades de tamanho intermediário e, 
especialmente investimentos em rodovias. A região de São Carlos faz parte de um dos vetores de expansão para o interior do Estado, dinamizado pela rede rodoviária que abrange a rodovia Washington Luís. Na década de 1980, a cidade teve seu crescimento impulsionado por esta estrutura rodoviária, que em conjunto com aspectos políticos, institucionais e tecnológicos consolidou a região como centro industrial de base tecnológica significativo no estado (SÃO CARLOS/FUSP, 2011). 


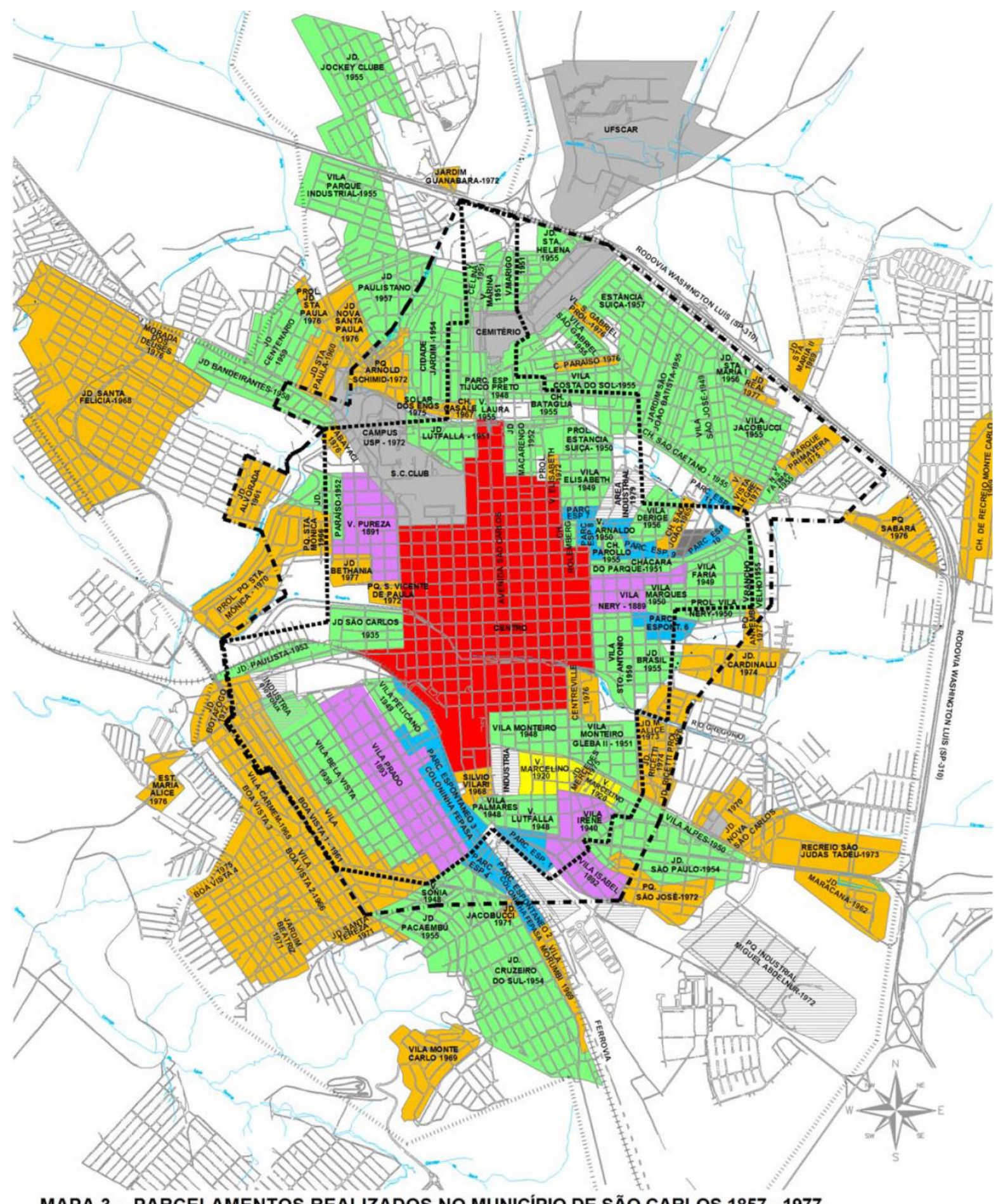

MAPA 3 - PARCELAMENTOS REALIZADOS NO MUNICÍPIO DE SÃO CARLOS 1857 - 1977

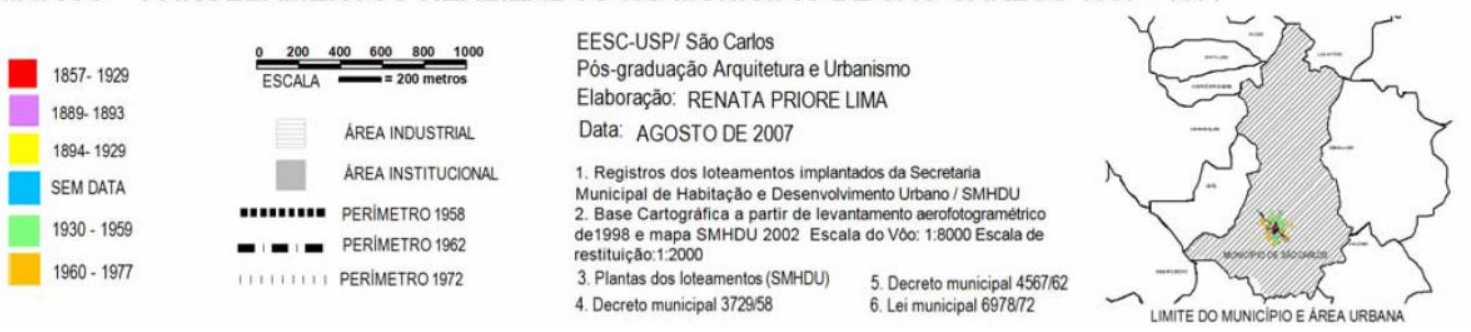

Figura 34: Mapa dos parcelamentos realizados entre os anos 1857-1977.

Fonte: LIMA, 2007, p. 130. 


\subsection{A questão ambiental e o planejamento urbano}

Nas décadas de 1980 e 1990, a cidade consolidou sua vocação industrial na área de alta tecnologia, apoiada na rede formada pelas universidades, parque tecnológico, institutos de pesquisa e escolas profissionalizantes, que impulsionaram o desenvolvimento da região. A expansão urbana continuou a ocorrer reafirmando os padrões de produção do território dos anos anteriores, bem como suas consequências ambientais e sociais.

Foram construídos bairros cada vez mais distantes do Centro e ao Sul da cidade, como o Cidade Aracy, loteamento popular constituído na década de 1980, inicialmente fora do perímetro urbano e carente de infraestrutura básica. Entre 2011 e 2015, no mesmo vetor de expansão, foram instalados dois empreendimentos do Programa Minha Casa Minha Vida da faixa 1, ambos ocupando a margem esquerda do córrego Água Quente, local impróprio para urbanização devido às características do solo, conforme alertara o Plano Diretor de 2005. Tais bairros se distinguem pela destinação à população de baixa renda e pela implantação em descontinuidade com a malha urbana, em localização complexa em termos ambientais, acentuada pela declividade no relevo e sua qualidade de solos arenosos. Esse processo, que consolida um bolsão de pobreza associando vulnerabilidades ambientais e sociais ao Sul do território urbano configura clara segregação socioespacial (SCHENK; PERES, 2014).

Na década de 2000, surgiram empreendimentos imobiliários de grande porte ao norte do Centro, tais como os da urbanizadora Damha, constituindo-se um complexo imobiliário que agrupou espaços residenciais fechados, e parque eco esportivo destinados a classes de maior poder aquisitivo. Os empreendedores se empenharam em oferecer um produto diferenciado pautado pela valorização dos espaços verdejados e de lazer privados, que, no entanto, não estabelecem relações diretas com seu entorno. Avançando sobre a área rural, este loteamento provocou mudanças do uso do solo, em que as fazendas de atividade agrícola se transformaram em produtos imobiliários.

Donoso (2011) ressaltou que a expansão ao norte do município foi incorporada ao Plano Diretor de 2005 como um dos eixos de crescimento da cidade, tendo em vista maior adequação à urbanização quanto às características do solo. Esta decisão vinha ao encontro aos interesses particulares dos incorporadores e de proprietários de terra. 
Populaçāo:

1940 - $48.609 \mathrm{hab}$

$1970-85.425 \mathrm{hab}$

2001 - 197.187 hab

2010-221.936 hab

até 1940

1940 a 1950

1950 a 1970

1970 a 1980
1980 a 1990

1990 a 2002

2002 a 2010

em implantação

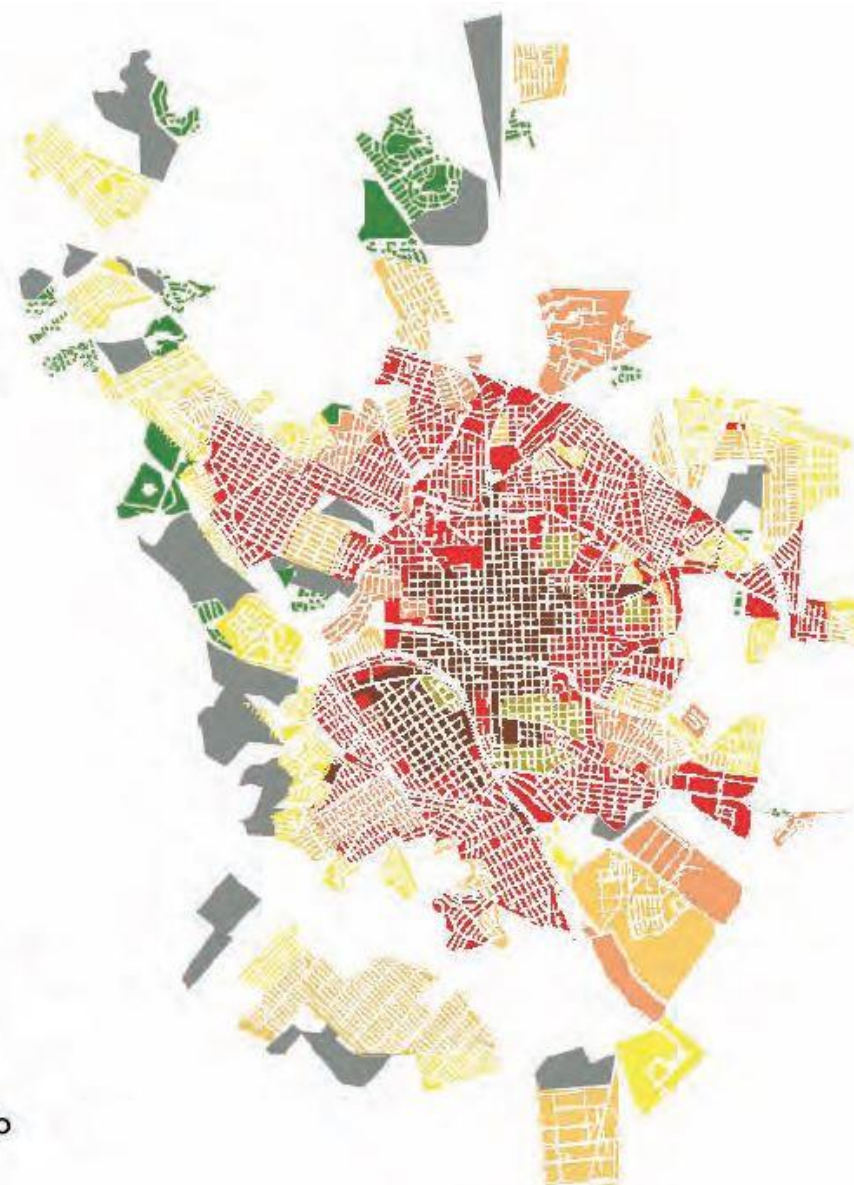

Figura 35: Mapa da Expansão Urbana de São Carlos. Fonte: DONOSO, 2011, p. 107.

\section{Termo de Ajustamento de Conduta (TAC) das Avenidas Marginais}

Frente a tantos problemas ambientais frutos de um modelo de ocupação urbana implementado ao longo dos anos em São Carlos, tornava-se urgente propor medidas mitigadoras desse processo. Nesse contexto, no ano de 1995, a Associação para Proteção Ambiental de São Carlos (APASC) moveu uma ação contra a Prefeitura em virtude da implantação de avenidas marginais nas APPs ao longo de cursos d'água sem licenciamento ambiental. Esta demanda contou com a interveniência do Ministério Público e resultou no Termo de Ajustamento de Conduta (TAC), que exigiu, entre outras medidas, a suspensão da implantação destas avenidas marginais pela Prefeitura em 2000.

A gestão do executivo municipal que assumiu em 2001 acatou a decisão judicial do TAC e designou uma comissão para elaboração de propostas e acordos que pretendiam minimizar 
os prejuízos ambientais devidos à implantação da infraestrutura viária em APP. De acordo com Anelli (2007, p. 16),

Os danos aos córregos e nascentes nas APPs marginais decorrem de causas que ultrapassam o simples desmatamento. Já foram citadas as retificações dos meandros e ocupação de várzeas, que alteram radicalmente o regime hidráulico da vazão das águas. A simples impermeabilização do solo na bacia hidrográfica, mesmo que respeitados a manutenção da vegetação ciliar e o traçado original dos meandros, impede que o curso d'água em área urbana permaneça na sua forma natural e exige um planejamento da macrodrenagem. $\mathrm{O}$ assoreamento dos trechos mais planos e a erosão dos trechos mais íngremes são constantes que independem da presença de mata nas margens.

O TAC também previa uma série de intervenções nos trechos de maior criticidade nos córregos Tijuco Preto, Monjolinho e Gregório e em seus efluentes, que consistiam na recuperação de mata ciliar ao longo dos cursos d'água e nas nascentes; no controle de erosão e assoreamento e no destamponamento de alguns trechos; na implantação de parque linear urbano; na elaboração e execução de projeto paisagístico (SÃO CARLOS, 2012). As intervenções foram realizadas parcialmente, a saber: a renaturalização de trecho do córrego Tijuco Preto; a duplicação da Avenida Dr. Francisco Pereira Lopes (córrego Monjolinho) e da Avenida Comendador Alfredo Maffei (córrego Gregório), que também constavam entre as intervenções, desde que realizadas com os afastamentos da margem dos cursos d'água e reconstituição de partes da APP (ANELLI, 2007).

Como compensação referente ao TAC, ocorreu a implantação do Parque do Kartódromo ${ }^{102}$ (SCHENK; PERES; FANTIN, 2017), executado a partir de 2004 na área Norte da cidade, às margens do córrego Monjolinho. O pequeno parque ocupa uma área de $22.620,00 \mathrm{~m}^{2} \mathrm{e}$, desde sua inauguração, é um ponto de grande convergência social, espaço para atividades físicas, sociais e de lazer e cultura.

A construção deste parque, em conjunto com outros dois parques a serem construídos no Córrego do Tijuco e no Córrego do Monjolinho, constituíam alternativas ao cumprimento do Termo apresentadas ao Ministério Público. Esta nova disposição buscava transformar a

\footnotetext{
$102 \mathrm{O}$ parque ficou conhecido por este nome, pois neste mesmo local funcionava uma pista para corridas de kart, implantada em 1976 e desativada em 2001 devido ao incomodo aos moradores do bairro do entorno. A pista foi construída sobre o antigo leito do córrego do Monjolinho, uma área de várzea sujeita a alagamentos no período das chuvas (PMSC). Fonte: Homepage: http://www.saocarlos.sp.gov.br/index.php/noticias-2006/149075parque-do-kartodromo.htm. Acesso em: 08 jan. 2020.
} 
condenação pela construção das marginais em estruturas que poderiam não apenas participar da mitigação das enchentes, mas agregar vida social e pública em seus espaços. Os projetos articulariam infraestrutura, mobilidade urbana e paisagem na direção da promoção de um desenvolvimento mais sustentável para a cidade.

As discussões acerca das propostas do TAC refletiram-se na incorporação da temática ambiental no projeto de lei do Plano Diretor Participativo (2005) de São Carlos, expressos na instituição de dispositivos de proteção das Áreas de Proteção Permanente urbanas e na definição de algumas das Áreas de Especial Interesse (AEIs) (ANELLI, 2007). O TAC também influenciou o projeto da Lei de Proteção dos Mananciais que seria aprovado em 2006.

\section{Plano Diretor Participativo (2005)}

Em relação ao processo de ordenamento do território urbano, a temática do Plano Diretor foi resgatada somente em 2001 como uma das prioridades da nova gestão que assumiu a prefeitura naquele momento, caracterizada pela estruturação e instrumentalização de seu corpo técnico, com o objetivo de orientar o crescimento urbano e minimizar os conflitos socioambientais. Docentes das Universidades locais e profissionais conceituados foram convidados a integrar o quadro da Secretaria de Habitação e Desenvolvimento Urbano (SHDU).

Diante da inexistência de dados e informações sistematizadas sobre o município, foram realizados, sob orientação da SHDU, diversos levantamentos, pesquisas e estudos que apontaram os impactos negativos resultantes dos processos inadequados de ocupação do solo e processos especulativos que desconsideraram os aspectos físicos e ambientais. Dentre os impactos evidentes podiam-se ressaltar os prejuízos causados ao meio natural pela urbanização de APPs, a baixa qualidade das águas urbanas devido à expansão sobre os mananciais e o risco à população por ocupar áreas impróprias.

As fragilidades ambientais estavam presentes em quase todas as direções da cidade: na direção Norte, havia a questão da transposição das Bacias Hidrográficas Tietê-Jacaré e Mogi-Guaçu, embora esta fosse a área de maior pressão especulativa e com demanda de expansão de condomínios fechados; na direção Leste, havia a presença das duas principais áreas de mananciais de abastecimento público da cidade; na direção Sul, havia um território com 
acentuados conflitos socioambientais ${ }^{103}$, sofrendo pressões por novas ocupações de loteamentos populares e, por fim, a direção Oeste apresentava uma condição de relevo e topografia desfavorável (PERES, 2012, p. 284).

O levantamento também permitiu o reconhecimento do território municipal como totalidade ao atentar para a extensa área rural constituída por atividades diversificadas como agrícolas, de lazer, industriais e habitacionais, indicando a necessidade de controle frente à pressão imobiliária e aos conflitos referentes aos usos e ocupações irregulares de algumas das atividades.

Ao longo desse processo de investigação, foi revelado um estoque de terras no interior da malha urbana, que configuravam grandes espaços livres. Contudo, um estudo mais detalhado para caracterização destes espaços não foi efetuado (PERES, 2012).

Em 2005, o Plano Diretor Participativo foi aprovado, guiado pelos princípios do Estatuto da Cidade e incorporando estratégias e instrumentos urbanísticos que procuravam valorizar as funções sociais da cidade e da propriedade e promover a sustentabilidade, pauta que permeou as discussões sobre desenvolvimento urbano e preservação ambiental na virada do século XX para o XXI. Como especial trunfo dessa Lei, uma maior atenção do poder público foi direcionada a conciliar planejamento urbano e qualidade ambiental. A dimensão ambiental foi expressa especialmente através da intenção de proteger os recursos hídricos e áreas de preservação ambiental, admitindo-se a bacia hidrográfica como unidade de planejamento e gestão do município na área rural. Em termos de regulação, ressalta-se a definição de diretrizes para promover a expansão da cidade, principalmente na região norte e oeste, ação que buscava salvaguardar as áreas de mananciais superficiais de abastecimento público (bacia hidrográfica do Monjolinho e do Feijão).

Na tentativa de ordenar a expansão e proteger o meio natural o território foi dividido em Macrozonas, Zonas e Áreas de Especial Interesse. O Macrozoneamento delimitou as áreas urbanas em Macrozona Urbana e, as áreas rurais e de transição em Macrozona de Uso Multifuncional Rural.

\footnotetext{
${ }^{103}$ A região Sul apresenta solos compostos principalmente por areias quartzosas profundas, caracterizando um solo frágil do ponto de vista geotécnico, com suscetibilidade à erosão (DONOSO, 2011).
} 


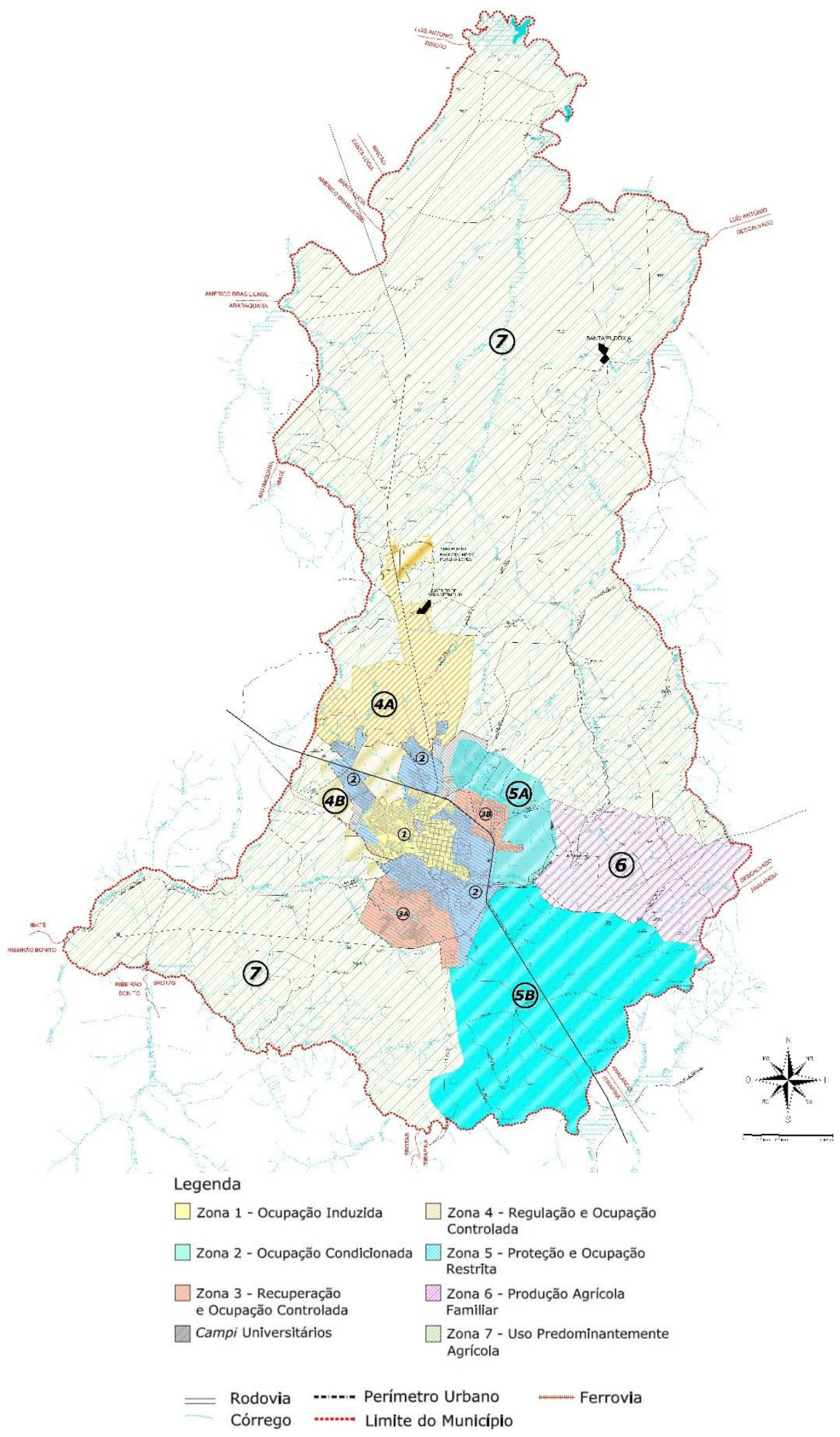

Figura 36: Mapa do Zoneamento do Município de São Carlos. Fonte: SÃO CARLOS, 2005. 
O zoneamento urbano (figura 36) foi pautado por questões referentes à capacidade de infraestrutura instalada e a densidade populacional, bem como a presença de acessos, barreiras e transposições viárias (PERES, 2012). Priorizou-se o adensamento urbano na perspectiva da cidade compacta, em consonância com o ideário urbanístico contemporâneo, pretendendo-se ocupar os vazios urbanos com a intenção de frear o modelo histórico de loteamentos dispersos, consequentemente aproveitando a infraestrutura instalada e reduzindo impactos ambientais. Esta área já urbanizada que se pretendia adensar, é representada no mapa (figura 36 ) pelas Zona de Ocupação Induzida (Zona 1), Zona de Ocupação Condicionada (Zona 2) e Zona de Ocupação Controlada (Zona 3), nesta última localizando-se a área de maior conflito socioambiental, o bairro Cidade Aracy, e parte da área de proteção do Manancial do Monjolinho (SÃO CARLOS, 2005).

As Zonas de Regulação e Ocupação Controlada (Zona 4A e Zona 4B) compreendiam as áreas de uso diversificado e de forte tendência para a expansão urbana (Norte e Oeste), configurando-se como transição entre o meio rural e o meio urbano. As diretrizes para estas zonas pretendiam regulamentar e disciplinar novos empreendimentos que implicassem na alteração do uso do solo rural, bem como conter parcelamentos e desmembramentos irregulares.

O restante da área do Manancial do Monjolinho foi denominado Zonas de Proteção e Ocupação Restrita, Zona 5A e Zona 5B, que seriam formadas pela bacia do Córrego do Feijão e parte da APA Estadual de Corumbataí. Nessa zona havia limitações ao crescimento urbano, com o estabelecimento de parâmetros mais restritivos de parcelamento, uso e ocupação do solo, visando promover a implementação de atividades compatíveis com a manutenção e a preservação do patrimônio ambiental e garantir a integridade ambiental do manancial (SÃO CARLOS, 2005).

O Plano trouxe também alguns instrumentos que potencialmente poderiam contribuir para a proteção do meio ambiente natural, tais como Estudo de Impacto de Vizinhança (EIV) e o Zoneamento Ambiental que, entretanto, não apresentando regulamentação específica, não foram aplicados (PERES, 2012).

Complementando o zoneamento, foram previstas as Áreas de Especial Interesse (AEIs), porções do território que exigiam tratamento especial por apresentarem características e 
funções específicas, sendo: Área de Especial Interesse Histórico; Área de Especial Interesse Ambiental; Área de Especial Interesse Turístico, Histórico e Ecológico; Área de Especial Interesse Turístico, Esportivo e Ecológico; Área de Especial Interesse Industrial; Área de Especial Interesse de Transporte Aéreo; Área de Especial Interesse Social. Destacam-se as Áreas Especiais de Interesse Ambiental (AEls ambientais) (figura 37), que apresentavam áreas destinadas a "proteger e recuperar os mananciais, nascentes e corpos d'água; a preservação de áreas com vegetação significativa e paisagens naturais notáveis; áreas de reflorestamento e de conservação de parques e fundos de vale" (SÃO CARLOS, 2005). Muitas destas áreas configuram APPs e a ação de incorporá-las às Áreas Especiais de Interesse Ambiental reforça a intenção de protegê-las.

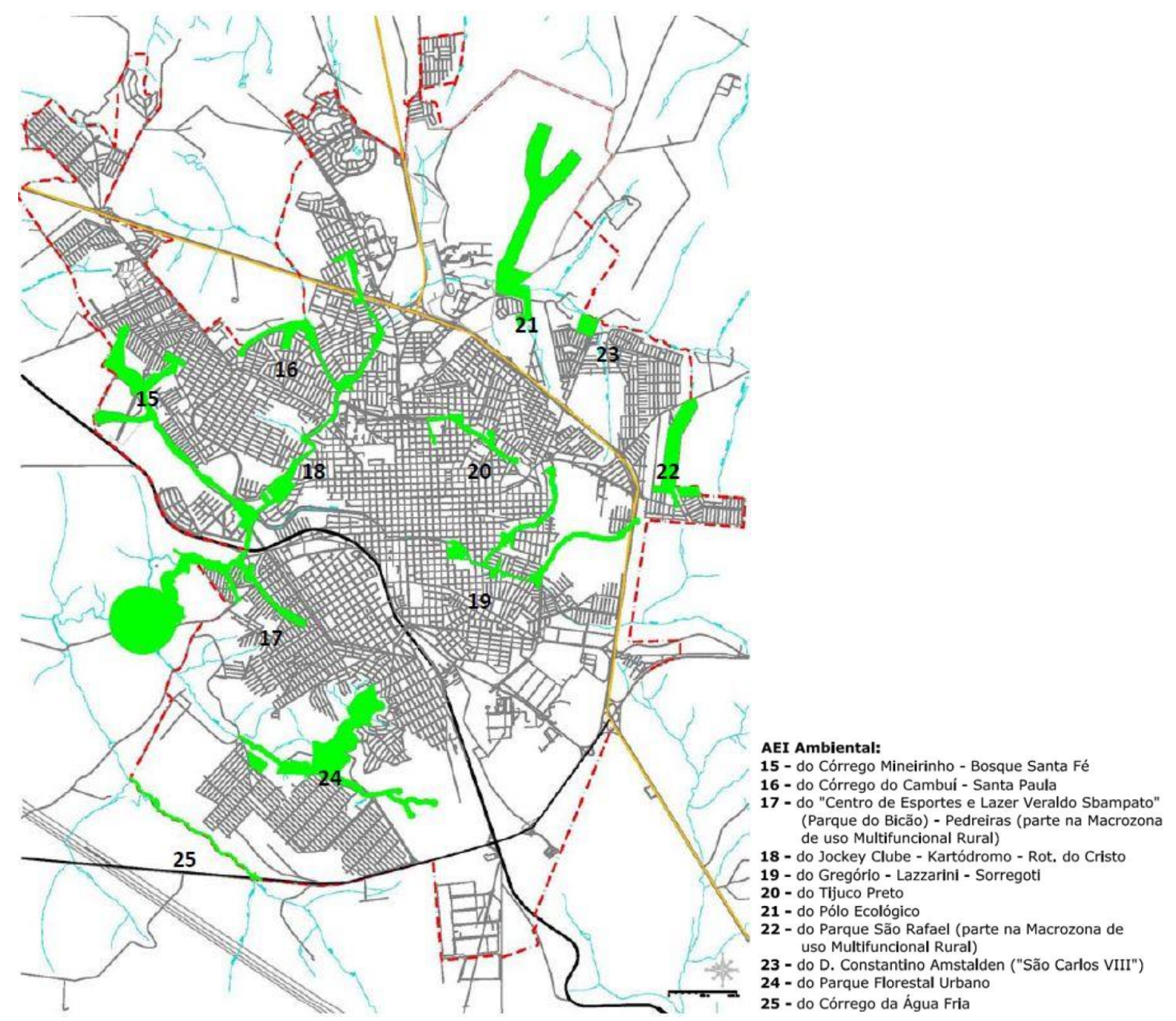

Figura 37: Mapa das Áreas Especiais de Interesse Ambiental do Município de São Carlos. Fonte: PERES, 2012, p. 295. 
O Plano (2005) tratava da destinação dos espaços livres no Capítulo sobre parcelamento do solo, que colocou a obrigatoriedade de reservar no mínimo $18 \%$ do território dos novos parcelamentos para áreas públicas, sendo 10\% para áreas de lazer e $8 \%$ para áreas de uso institucional. Segundo a Lei, seria responsabilidade do Poder Executivo Municipal, por meio da Certidão de Diretrizes, definir a localização destas áreas e uma eventual alteração de seus percentuais, colocando a possibilidade das áreas de lazer se localizarem contiguamente às APPs, como forma de ampliação da faixa de proteção ambiental dos corpos d'água. Nestes casos, não haveria a limitação da declividade máxima de $20 \%$ para implantação, declividade exigida para as outras situações. As APPs não seriam computáveis no cálculo de áreas públicas e, do mesmo modo, não seriam computáveis as áreas de risco à vida e à saúde e as faixas de servidão ao longo das linhas de transmissão de energia elétrica.

Os espaços livres foram abordados como áreas restantes dos parcelamentos, não havendo a exigência de qualificação. O Plano colocava apenas que as áreas de lazer poderiam ser utilizadas para práticas de esporte e recreação, implantação de bacias de retenção de águas pluviais, praças, parques com alamedas e maciços arbóreos. Não havia a menção a um Sistema de Espaços Livres ${ }^{104}$.

Vale destacar outras medidas incorporadas ao Plano almejando dirimir o impacto do processo de urbanização e proporcionar melhores condições para a drenagem urbana através dos coeficientes de permeabilidade e de cobertura vegetal e de dispositivos de drenagem. 0 Coeficiente de Permeabilidade ${ }^{105}$ foi diferenciado para cada Zona, baseado em características do local e no tamanho do lote. O Coeficiente de Cobertura Vegetal ${ }^{106}$ teria aplicação somente nas áreas de mananciais, constituídas pelas Zonas 3B, 5A e 5B. Além disso, os parcelamentos deveriam apresentar um projeto de drenagem prevendo poços de infiltração, bacias de retenção de águas pluviais, dispositivos de dissipação de energia e pavimentos permeáveis, concebidos com o objetivo de manter as condições originais da vazão de escoamento da área

\footnotetext{
${ }^{104}$ Dentro de uma perspectiva que tem como referência o campo teórico da Paisagem e do Planejamento em registro contemporâneo, Schenk e Peres (2014) apontaram para a associação das AEls ambientais à instalação de novos espaços livres qualificados, constituindo um sistema que articula praças, ruas arborizadas e parques, estes últimos reunindo lugares de recreação e descanso, na intenção de articular lazer e proteção ao ambiente natural. Esta temática será abordada no próximo capítulo.

105 "O Coeficiente de Permeabilidade (CP) é entendido como a relação existente entre a área permeável e a área do terreno" (SÃO CARLOS, 2005, art. 160).

106 "O Coeficiente de Cobertura Vegetal (CCV) é a relação entre a área coberta por vegetação arbórea ou arbustiva de um determinado imóvel e a sua área total [...]" (SÃO CARLOS, 2005, art. 162).
} 
antes de ser loteada, visando reduzir o impacto causado pela impermeabilização resultante dos parcelamentos (SÃO CARLOS, 2005).

O Plano Diretor de 2005 incorporou alguns parâmetros visando a melhora das condições ambientais, porém não conseguiu frear os processos especulativos, sobretudo ao sul do município, área de fragilidade do ponto de vista socioambiental. Desta forma, além da expansão urbana ao Sul, local de moradia da população de menor poder aquisitivo, consolidou-se o vetor crescimento ao Norte e Noroeste (sugeridos pelo Plano), associados, principalmente, aos condomínios fechados de médio e alto padrão. Tais fatos reforçaram a segregação socioespacial e o aumento do perímetro urbano. (PERES, 2012).

Schenk, Peres e Fantin (2017) apontaram aspectos positivos a respeito do Plano Diretor de 2005 referentes à perspectiva de inclusão da geografia física na constituição das diretrizes de planejamento, atentando-se para o processo de leitura e compreensão do território como informações relevantes, que deveriam nortear as políticas públicas relacionadas ao Município de São Carlos.

A qualidade das cartografias e textos, que expressaram os dados com clareza, possibilitaram a compreensão por qualquer cidadão, de forma que pudessem participar desse estudo e, principalmente, das decisões acerca do território.

No entanto, durante a vigência deste Plano, de 2005 a 2016, as gestões concentraramse, sobretudo, no controle sobre a aprovação de projetos, parcelamentos e na definição do zoneamento urbano. Além disso, foram encontradas lacunas e ambiguidades na lei, que somadas à pressão exercida pelo poder econômico ligado aos grandes proprietários de terra, culminaram em retrocessos na gestão do uso e ocupação do solo de São Carlos (SCHENK, PERES, FANTIN, 2017).

Para completar o arcabouço normativo, o Plano Diretor (2005) indicou a elaboração de Leis e Planos Setoriais, dos quais se destacam: Lei das Áreas de Proteção e Recuperação dos Mananciais e Plano de Macrodrenagem Urbana.

\section{Lei das Áreas de Proteção e Recuperação dos Mananciais (APREMs)}

A Lei das Áreas de Proteção e Recuperação dos Mananciais (Lei no 13.944/2006) foi elaborada durante a aprovação do Plano Diretor Participativo (2005), repercutindo em 
Diretrizes, Zoneamentos, Coeficientes e Parâmetros Construtivos diferenciados para este Plano (PERES, 2012). Conhecido como Lei dos Mananciais, o regulamento instituiu "áreas de relevante interesse ambiental municipal, destinadas ao cumprimento da função social e ambiental de proteção, preservação e conservação do abastecimento de água com qualidade" (SÃO CARLOS, 2006, Art. 1ㅇ). A delimitação destas áreas incluiu parte da microbacia hidrográfica do Córrego Monjolinho, à montante da Estação de Captação de Água do Espraiado, e parte da microbacia do Ribeirão Feijão, dentro dos limites do Município, à montante da Estação de Captação de Água para abastecimento público de São Carlos.

Para a aplicação de dispositivos normativos foram criadas as áreas de controle (figura 38), que classificou as APREMs, em: I - Áreas de Preservação; II - Áreas de Ocupação Dirigida; III - Áreas de Recuperação Ambiental. As Áreas de Preservação foram subdivididas em Subárea de Preservação 1 (SAPRE 1), que corresponde às áreas definidas como de preservação permanente de acordo com a legislação federal, estadual ou municipal; e Subárea de Preservação 2 (SAPRE 2), que constitui uma faixa de proteção de $50 \mathrm{~m}$ a partir da SAPRE 1 . As atividades permitidas nas SAPREs não podem colocar em risco a integridade e a qualidade dos corpos d'água, correspondendo essencialmente em: atividades de contemplação da natureza, educação ambiental e pesquisa; instalação de sistemas de drenagem; serviços e obras destinados à proteção, preservação, conservação ou recuperação do manancial; pesca recreativa; manejo sustentável da vegetação, exclusivamente para fins de preservação e conservação da fauna e flora (SÃO CARLOS, 2006). 


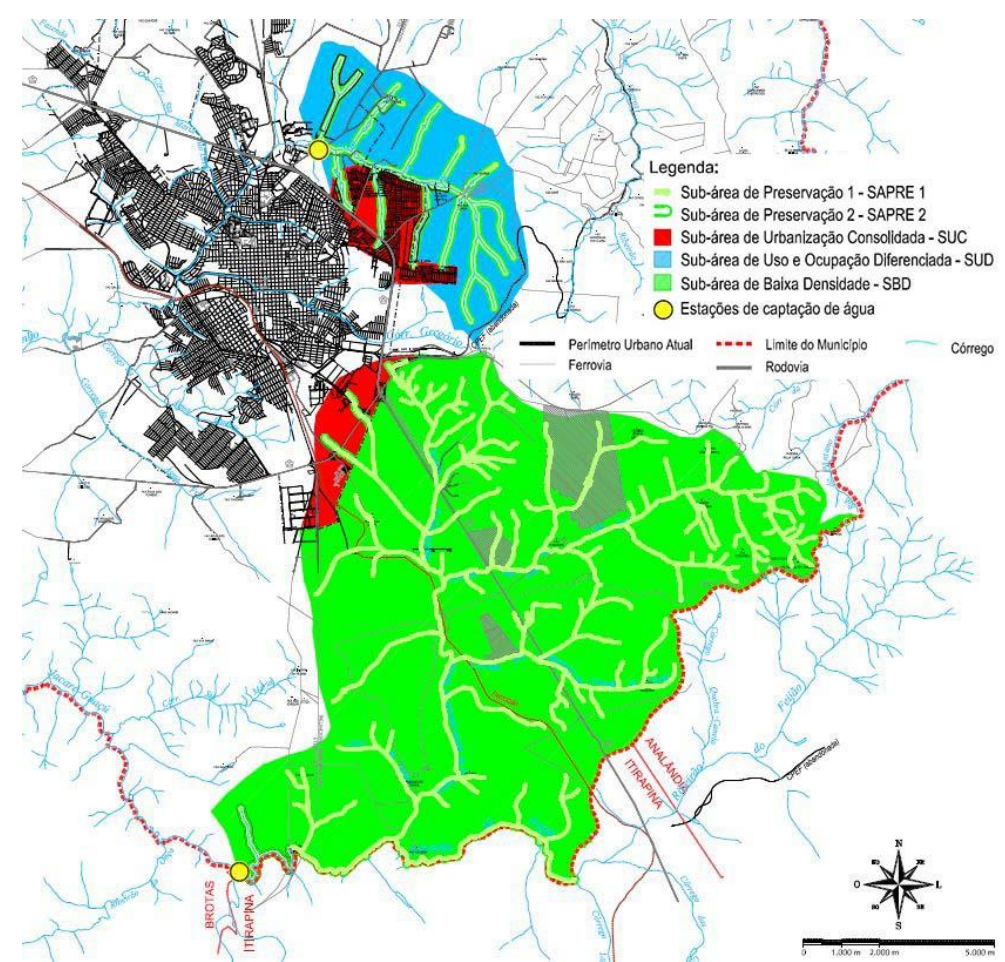

Figura 38: Mapa de localização das APREMs.

Fonte: SÃO CARLOS, 2006.

As Áreas de Ocupação Dirigida são de interesse para a consolidação ou a implantação de usos urbanos ou rurais condicionados ao atendimento dos requisitos que assegurem a manutenção das condições ambientais necessárias à produção de água; são subdivididas em:

I - Subárea de Urbanização Consolidada - SUC: composta pelas áreas urbanas consolidadas, pelos empreendimentos de parcelamento do solo já aprovados pelos órgãos competentes, e por glebas localizadas dentro da Zona 3B - Zona de Recuperação e Ocupação Controlada e parte da Zona 2 Zona de Ocupação Condicionada, definidas no Plano Diretor do Município de São Carlos - Lei Municipal no 13.691 de 25 de novembro de 2005;

II - Subárea de Uso e Ocupação Diferenciada - SUD: composta predominantemente por imóveis rurais localizados à montante da Estação de Captação do Espraiado, devendo ser planejada e monitorada de acordo com o disposto na legislação pertinente;

III - Subárea de Baixa Densidade - SBD: composta predominantemente por espaços livres e áreas verdes destinadas preferencialmente a sítios, chácaras de lazer e turismo local, localizados a montante da captação do Ribeirão do Feijão (SÃO CARLOS, 2006, Art. 15).

Nessas áreas foram estabelecidos diversos parâmetros urbanísticos diferenciados ${ }^{107}$ para os parcelamentos regulares já existentes e para futuros parcelamentos das glebas

107 Resumidamente; para os parcelamentos existentes: Coeficiente de Aproveitamento, Coeficiente de Ocupação, Coeficiente de Permeabilidade, Coeficiente de Cobertura Vegetal, implantação de poço absorvente 
remanescentes. Esse planejamento tinha o objetivo de evitar o processo de ocupação intensiva da área, bem como disciplinar a implantação de novos empreendimentos. Tais ações procuraram fomentar ainda a prática do turismo ecológico sem comprometer a integridade dos mananciais, preservando os agrupamentos vegetais de porte arbóreo existentes.

As áreas com atividades ou usos que comprometiam a quantidade ou a qualidade dos mananciais foram classificadas como Áreas de Recuperação Ambiental (ARA), para as quais o Poder Público pretendia desenvolver um Programa de Recuperação com intervenções de caráter corretivo.

Como foi exposto anteriormente, estas áreas de mananciais, sobretudo nas proximidades do Córrego Monjolinho, vinham sofrendo pressão da expansão urbana, o que indicava a necessidade da adoção de medidas restritivas para o uso e ocupação. Na Lei de Mananciais destaca-se a utilização da bacia hidrográfica como unidade de planejamento, ainda que não na sua totalidade, na intenção de articular a gestão do solo e a proteção dos recursos naturais, visando a proteção e a recuperação dos recursos hídricos sobretudo por constituírem estações de captação de água para o abastecimento da cidade.

Peres (2012) relatou a importância desta lei que se articulou ao Plano Diretor (2005) e freou a urbanização na área dos mananciais, mas advertiu para a necessidade de aperfeiçoamento quanto aos critérios para o licenciamento e aprovação de atividades.

Em termos ambientais, essa foi considerada uma grande conquista social que foi incorporada no Plano Diretor e que teve repercussões concretas no sentido de frear a aprovação de loteamentos, e, consequentemente, conter a expansão urbana em áreas de elevada qualidade hídrica com potencial de preservação (PERES, 2012, p. 311).

\section{Plano Diretor de Drenagem Urbana Ambientalmente Sustentável}

Integrando os planos setoriais sugeridos pelo Plano Diretor Participativo (2005), em 2009 a empresa SHS Consultoria e Projetos de Engenharia SS Ltda iniciou, com fiscalização da Secretaria Municipal de Obras Públicas, a elaboração do Plano Diretor de Drenagem Urbana Ambientalmente Sustentável do Município de São Carlos. O objetivo deste Plano era dar

para as águas pluviais incidentes no lote; implantação de pavimentos permeáveis ou com baixo coeficiente de escoamento. Para os novos parcelamentos: além dos coeficientes citados acima, lote mínimo de $500 \mathrm{~m}^{2}$; implantação de sistema de drenagem; conservação e manutenção dos maciços vegetais de porte arbóreo já existentes (SÃO CARLOS, 2006). 
subsídios técnicos e institucionais à Prefeitura Municipal para reduzir os impactos das inundações e criar condições para uma gestão sustentável da drenagem urbana (SÃO CARLOS, 2012).

Nesse processo realizou-se uma pesquisa detalhada das condições da rede hídrica da cidade, através de visitas técnicas e da realização de levantamento cartográfico com uso de Sistemas de Informação Geográfica (SIG), que possibilitou analisar as características do meio físico (geomorfologia, geologia, pedologia), bem como articular estes dados ao zoneamento e ao uso e ocupação do solo. Com base em todas as informações coletadas, foi produzido um mapeamento da cidade (Figura 39), em que se apresentaram os principais problemas de drenagem.

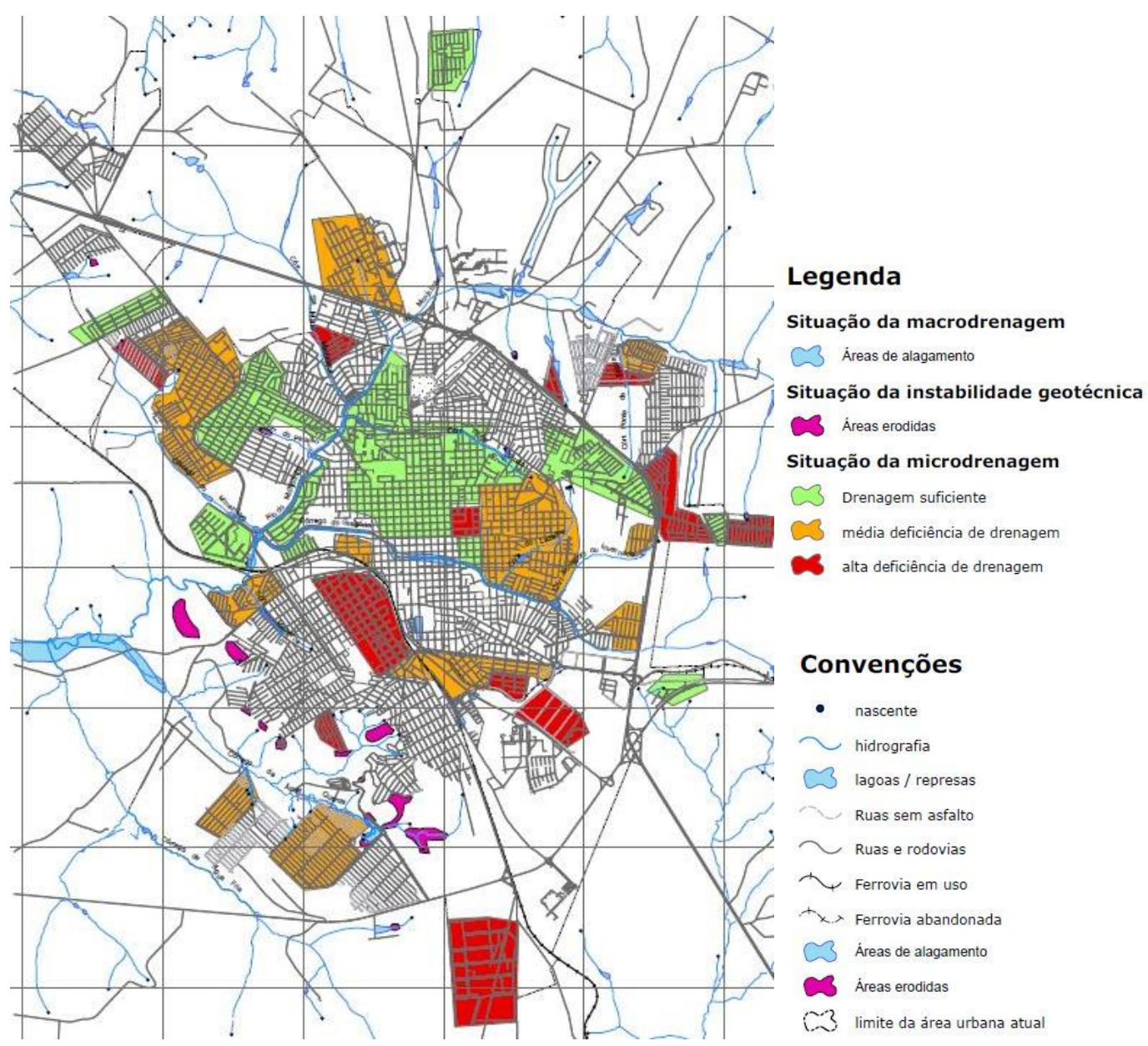

Figura 39: Mapa das Criticidades.

Fonte: Plano Diretor de Drenagem Urbana Ambientalmente Sustentável do Município de São Carlos, 2011. 
Como resposta aos problemas de drenagem, previa-se a realização de medidas estruturais e não estruturais. De acordo com o Plano Diretor de Drenagem Urbana (2011), a adoção de medidas estruturais ocorre quando é necessário o controle dos impactos existentes e dos problemas instalados ou eminentes no sistema de drenagem em estudo, consistindo na proposição de reservatórios de água. Quando localizados no próprio curso d'água, estes são denominados reservatórios on-line, sendo de duas tipologias: bacias de detenção, reservatórios secos projetados para reter águas superficiais apenas durante eventos chuvosos e bacias de retenção, que mesmo em período de estiagem contenham um volume de água para cumprir finalidades paisagísticas, recreacionais, entre outras. No caso de desvios dos volumes de água da rede de drenagem natural principal durante os eventos chuvosos para o alívio nos picos de vazões e posterior restituição, propõem-se os reservatórios off-line. Foram propostos pelo Plano 23 dispositivos hidráulicos (figura 40), sendo a maioria novos, com a finalidade do controle de cheias, e dois dispositivos para o controle de erosões (SÃO CARLOS/SHS, 2011).

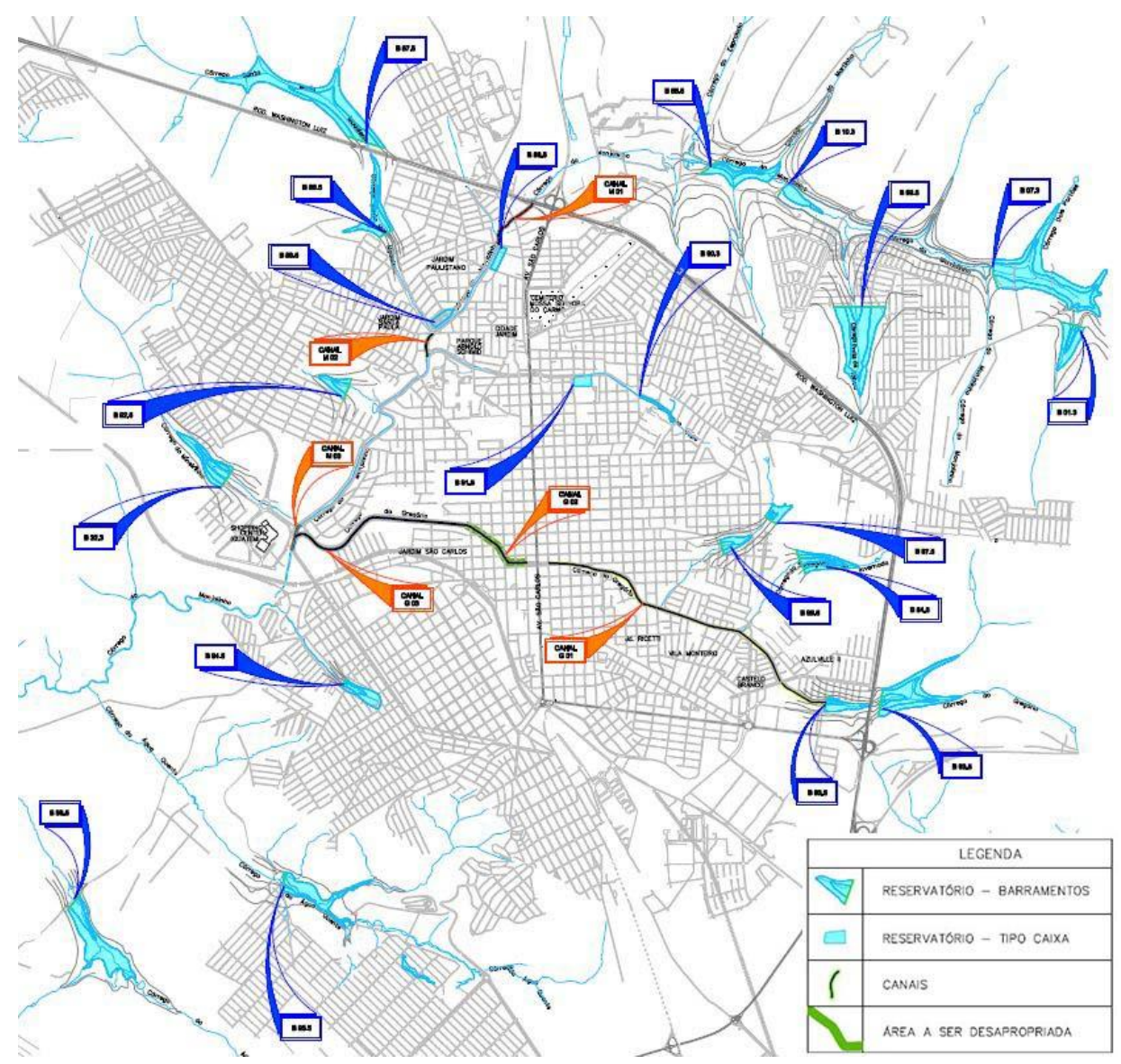

Figura 40: Mapa da localização dos reservatórios e canais. Fonte: SÃO CARLOS/SHS, 2011, Anexo 21. 
As medidas não estruturais têm o propósito de prevenir e gerenciar eventos críticos em macrodrenagem, evitando a ocorrência de impactos na rede hídrica. Dentre algumas destas medidas o Plano citou: a capacitação de técnicos da Prefeitura Municipal para operacionalizar as ações previstas pelo Plano Diretor de Drenagem Urbana, assim como o aprimoramento desta lei. E medidas compensatórias para controle dos volumes adicionais de escoamento decorrentes da impermeabilização do solo, como: utilização de pavimentos permeáveis; retenção de água no lote; reuso de águas pluviais; a recuperação ou preservação de áreas sensíveis ou de interesse para infiltração de águas pluviais.

O Plano Diretor de Drenagem Urbana Ambientalmente Sustentável fez um amplo estudo das condições da drenagem urbana de São Carlos, através do levantamento de bases cartográficas, formulação de cenários, diagnóstico e prognóstico, que testaram diferentes modelos de cálculo para a proposição de medidas tantos estruturais quanto não estruturais. O documento apresentou ainda os projetos dos dispositivos de drenagem em nível de anteprojeto, e um manual de drenagem urbana com diversas recomendações, bem como os custos de implantação do sistema e os instrumentos legais relacionados à drenagem. No entanto, o Plano não dialoga com o Sistema de Espaços Livres enquanto espaços que podem funcionar como infraestrutura verde de drenagem e locais de sociabilidade.

\section{O Plano Diretor Estratégico (2016)}

O processo de revisão do Plano Diretor contou, num primeiro momento, com a participação do Instituto de Arquitetura e Urbanismo (IAU) através da Fundação USP do Campus São Carlos (FUSP) que, em parceria com a Prefeitura do Município (PMSC) elaborou uma proposta que dava continuidade à pauta ambiental inaugurada pelo Plano Diretor de 2005.

Nesta perspectiva retomou-se o planejamento territorial por bacia hidrográfica devido ao seu potencial de articulação entre escalas planejamento e quanto a integração do município como um todo. O macrozoneamento baseava-se nas duas Unidades de Gerenciamento de Recursos Hídricos (UGRHIs) da qual o município faz parte: Macrozona da Bacia Hidrográfica do Tietê-Jacaré (MTJ), na qual está inserida a maior parte da área urbana, e Macrozona da Bacia Hidrográfica do Mogi-Guaçu (MMG), para onde avança a urbanização 
(SÃO CARLOS/FUSP, 2012a). A compreensão da bacia hidrográfica como unidade de planejamento e gestão, já consagrada na historiografia do planejamento regional e retomada pela Política Nacional dos Recursos Hídricos (Lei $n$ ㅇ 9.433/1997) foi utilizada no zoneamento municipal, atestando a incorporação das questões do meio físico e suas relações com o processo de ocupação como temática fundamental.

Buscando a consideração dos aspectos ambientais e a superação da dicotomia ruralurbano, muitas vezes ineficaz para abranger a complexidade funcional do território, recorreuse ao zoneamento ambiental ${ }^{108}$ como forma de direcionar a expansão urbana evitando as áreas ambientalmente frágeis.

Esse instrumento, no entanto, pode ser aplicado no processo de identificação de aptidões e vulnerabilidades no território municipal, como fragmentos territoriais que possuam fragilidades para determinados usos ou que apresentem características desejáveis para outros usos, para a elaboração do ordenamento e aproveitamento territorial. Entendemos, desta forma, que o zoneamento ambiental permite sua aplicabilidade quando utilizado como um instrumento para elaboração do zoneamento municipal e para a definição dos parâmetros de uso e ocupação do solo (SÃO CARLOS/FUSP, 2012a, Etapa 2, p. 8).

A análise do município considerava as fragilidades ambientais relacionadas à declividade, pedologia, fragmentos de vegetação remanescente, áreas de preservação permanente ciliares, bem como o uso do solo. Por meio da sobreposição de cartografias referentes a estes dados, articulados ao mapa da estrutura viária municipal, produziu-se um mapa síntese do Zoneamento Municipal para o ordenamento. Frente à verificação da degradação socioambiental associada à expansão urbana, as diretrizes desta proposta indicavam maior adensamento junto à área urbana consolidada e preenchimento dos vazios, medida que já vinham ocorrendo desde o Plano Diretor de 2005 como meio de alcançar uma cidade compacta e evitar o avanço sobre áreas ambientalmente frágeis e de preservação.

O documento elaborado pelo IAU definia ainda alguns Projetos Estratégicos que seriam implementados nas áreas gravadas como de especial interesse, tendo o objetivo de valorizar, qualificar, potencializar o desenho urbano e o patrimônio natural, cultural e paisagístico. Destacam-se os projetos de relevância ambiental, que pretendiam articular áreas de preservação ambiental ao lazer, ao esporte, à cultura. Na área urbana foi proposto um

108 O Plano Diretor de 2005 trouxe esse instrumento, porém não houve sua regulamentação. 
sistema de lazer integrado à preservação ambiental através da criação de parques lineares com equipamentos como playground, pista de caminhada, academia ao ar livre, ciclovia e áreas de estar. Com a clara intenção de otimizar os espaços livres obrigatórios relacionados aos processos de parcelamento, existiam diretrizes específicas, que determinavam a localização das áreas de lazer dos parcelamentos no entorno dos parques lineares deveriam ser adjacentes a eles. Para as bordas da cidade foram indicados os parques florestais municipais como o Parque Florestal da Bacia do córrego Água Quente, local de solos frágeis e grande potencial paisagístico, e o Parque Florestal da Bacia do Feijão, que deveria configurar como unidade de conservação devido à significativa cobertura florestal e localização estratégica em relação à captação de água. Em relação à área rural, foram indicados projetos de turismo ecológico e preservação do patrimônio natural associados ao patrimônio histórico (SÃO CARLOS/FUSP, 2012b).

A revisão produzida pelo IAU em parceria com a Prefeitura buscava uma leitura transversal do município, relacionando dinâmicas socioespaciais e físico-territoriais, de tal forma que sua perspectiva se aproximava de todo o campo do conhecimento que norteia o planejamento com a paisagem. Entretanto, essa proposta foi intensamente alterada pelo novo corpo técnico da gestão que assumiu o poder executivo em 2014 (SCHENK; PERES; FANTIN, 2015). Muitos conflitos engendrados pelos diferentes interesses em jogo na produção da cidade foram discutidos pelo Núcleo Gestor Compartilhado, instituído pelo Ministério Público para garantir a participação da população no processo. Seguiu-se uma série de negociações e embates entre, de um lado, o mercado imobiliário e os grandes proprietários de terra e, do outro, as Universidades e as Organizações não Governamentais (ONGs) relacionadas ao meio ambiente (SCHENK; PERES; FANTIN, 2016).

O Plano Diretor Estratégico (Lei no 18.053/2016) foi aprovado em dezembro de 2016, sendo o resultado de grande negociação entre os interesses do mercado imobiliário e a defesa do bem comum e da função social da propriedade encabeçados pelas Universidades e ONGs. Algumas conquistas foram garantidas, porém por mais que este Plano expresse em seu texto a busca de um meio ambiente ecologicamente equilibrado, colocando como dever do Poder Público Municipal o provimento de usos do solo compatíveis com a preservação ambiental, 
o perímetro urbano aumentou consideravelmente, avançando sobre áreas ambientalmente vulneráveis ao sul da cidade.

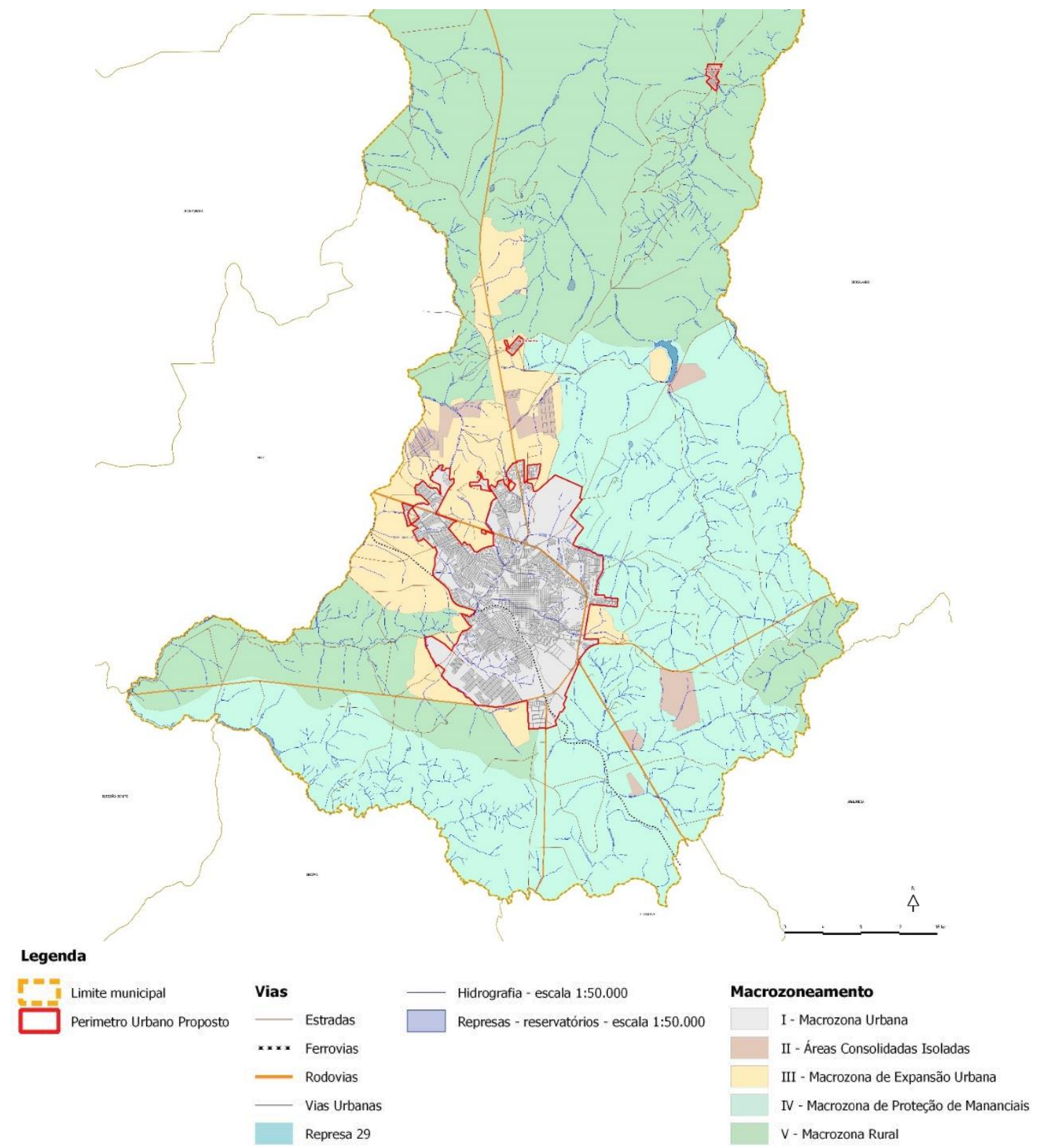

Figura 41: Mapa do Macrozoneamento Municipal. Fonte: SÃO CARLOS, 2016.

O macrozoneamento (figura 41) do Plano aprovado dividiu o município em Macrozona Urbana e de Estruturação e Qualificação Urbana (Zona Urbana composta pelas Zonas 1, 2, 3, 4, 5 e pelas Áreas Consolidadas Isoladas) e, Macrozona Rural (Zona Rural composta pela Zona 9A; Zona de Expansão Urbana, composta pelas Zonas 6 e 7; Zona de Proteção de Mananciais, 
composta pelas Zonas 8 e 9B). Pelo mapa acima (figura 41) é possível visualizar as áreas destinadas à expansão urbana ao Sul, a Oeste em direção ao limite municipal e principalmente ao Norte, seguindo o eixo da rodovia Eng. Thales de Lorena Peixoto Junior e transpondo para a Bacia Hidrográfica do Mogi-Guaçu a legalidade da ocupação urbana.

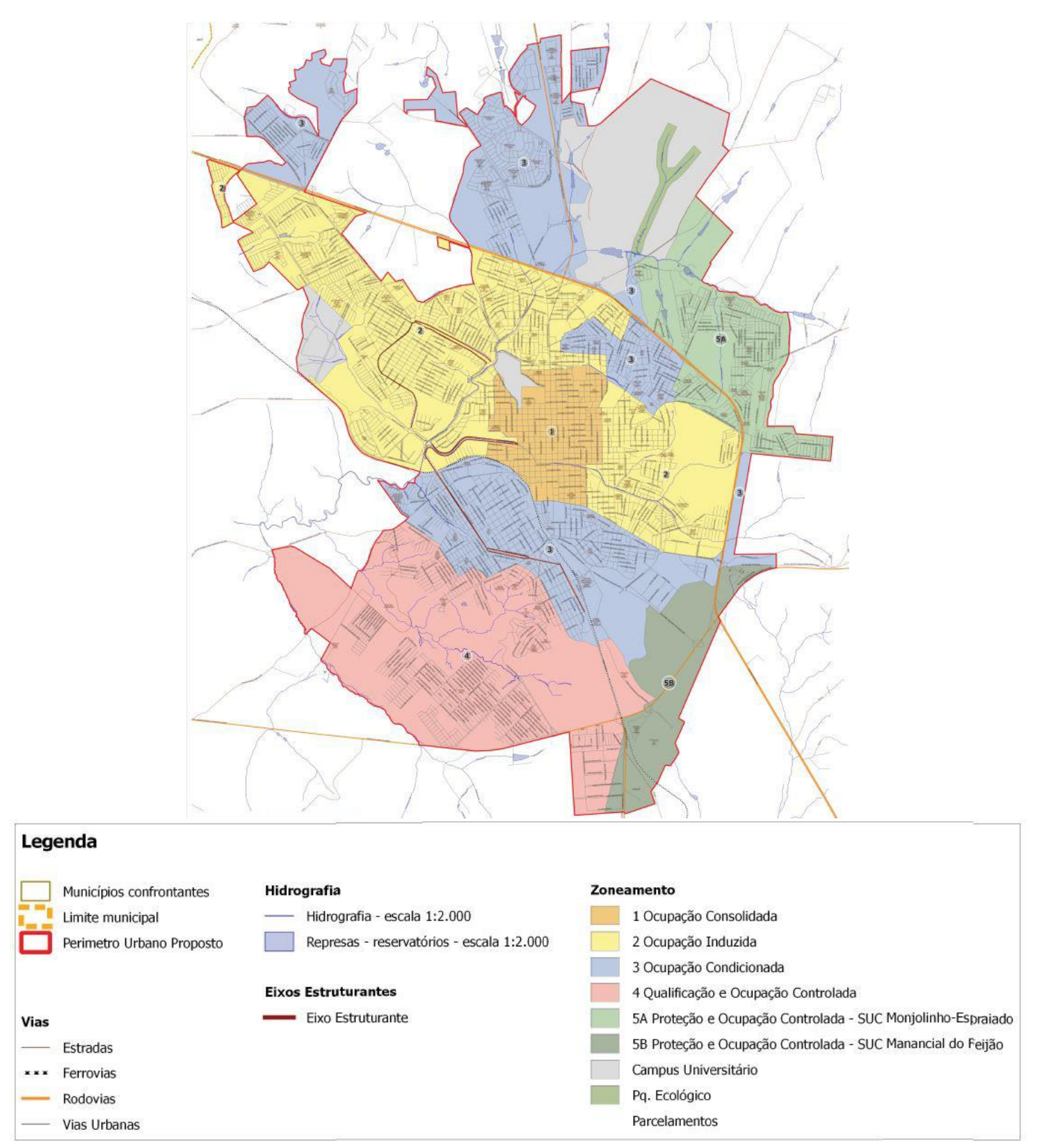

Figura 42: Mapa do Zoneamento Urbano. Fonte: Adaptado de SÃO CARLOS, 2016.

O zoneamento municipal (figura 42) é composto por 9 zonas e eixos estruturantes, conformados pelas principais vias urbanas, com o objetivo de incentivar o adensamento 
destas áreas através de empreendimentos de uso misto entre habitação, comércio e serviço. As zonas 1 - Ocupação Consolidada, 2 - Ocupação Induzida, 3 - Ocupação Condicionada visam, principalmente, o aproveitamento da infraestrutura urbana instalada, orientando para a ocupação dos vazios urbanos. A zona 4 - Qualificação e Ocupação Controlada, caracterizada pela presença de bairros populares ou situações de vulnerabilidade social, apresentam demandas por infraestrutura, indicando diretrizes para recuperar e qualificar os elementos urbanos, sociais e ambientais. A zona 5 - Proteção e Ocupação Controlada, refere-se às regiões de proteção dos mananciais do Monjolinho-Espraiado (zona 5A) e do Ribeirão do Feijão (zona 5B) dentro do perímetro urbano, e que apresentam restrições ao adensamento construtivo e populacional. Nesta zona seguem-se as orientações (coeficientes urbanísticos e faixas de APP) da Lei da APREM (Lei Municipal no 13.944/2006).

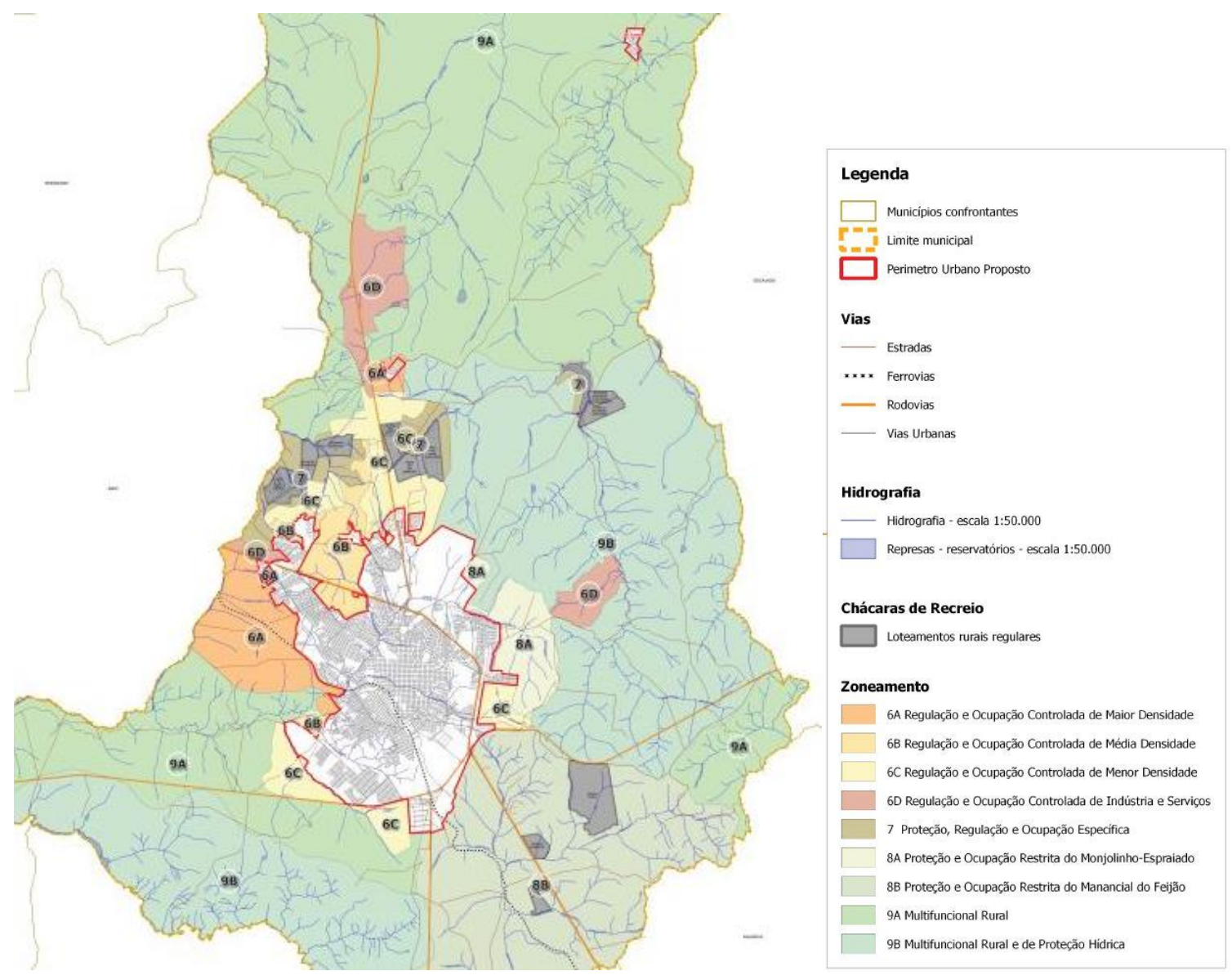

Figura 43: Mapa do Zoneamento Rural. Fonte: Adaptado de SÃO CARLOS, 2016. 
A zona 6 - Regulação e Ocupação Controlada (figura 43), foi subdividida com base nas características físicas locais que determinam a densidade de ocupação, sendo a zona 6A de maior densidade por sua aptidão à urbanização, a Oeste do perímetro urbano. A zona 6B, de média densidade, é composta pela bacia do Santa Maria do Leme, parte da bacia hidrográfica do Chibarro e parte da bacia hidrográfica do Água Quente, que de acordo com o Plano (2016) são áreas aptas à urbanização, mas que exigem controle na ocupação. A zona 6C, apresenta menor densidade devido às características físico-ambientais, tais como solos arenosos ao Sul e ao Norte, divisor de águas entre as bacias do Jacaré e do Mogi ao Norte, nascentes a Leste, e insuficiência de infraestrutura, principalmente de drenagem, sendo necessário um plano específico de ocupação para esta zona. O planejamento do adensamento da zona 6B e 6C deve prever a proteção e recuperação das APPs e das faixas verdes complementares de 30 metros além das APPs, havendo nesses lugares a necessidade de previsão de infraestrutura de drenagem e de mobilidade urbana. Para a zona 6C, foi indicada a realização do Plano Integrado de Ocupação, uma exigência do grupo de oposição (ONGs, associações de bairro, universidade) à nova proposta de Plano Diretor, visando garantir a qualidade de vida e ambiental da população residente neste local (SCHENK; PERES; FANTIN, 2016). A última subdivisão desta zona é a zona 6D - Regulação e Ocupação Controlada de Indústrias e Serviços, composta de áreas destinadas ao uso de logística, serviços e indústrias (SÃO CARLOS, 2016).

A zona 7 - Proteção, Regulação e Ocupação Específica (figura 43), localiza-se ao Norte da cidade, envolvendo loteamentos de chácaras de recreio, fragmentos de vegetação nativa e remanescentes de APPs. Essa área apresenta solos arenosos e áreas alagadiças e, por estar inserida na Zona de Expansão Urbana, seus os índices urbanísticos são mais restritivos ${ }^{109}$ e as diretrizes pretendem proteger e recuperar áreas ambientalmente frágeis indicadas acima.

A zona 8A - Proteção e Ocupação Restrita do Monjolinho-Espraiado e a zona 8B Proteção do Manancial do Ribeirão Feijão (figura 43) encontram-se externas ao perímetro urbano e constituem as principais áreas de recarga e captações superficiais de água da cidade, estando em conformidade com a Lei Municipal no 13.944/2006 (Lei dos Mananciais). Portanto, de acordo com esta lei, correspondem, respectivamente, à Subárea de Uso e Ocupação

\footnotetext{
${ }^{109} \mathrm{Na}$ zona 7 os índices urbanísticos são: $\mathrm{CO}=25 \%, \mathrm{CP}=50 \%, \mathrm{CCV}=50 \%, \mathrm{CA}=0,25$, lote mínimo $=1500 \mathrm{~m}^{2}$, testada mínima $=20 \mathrm{~m}$ (SÃO CARLOS, 2016).
} 
Diferenciada (SUD) e à Subárea de Baixa Densidade (SBD). Nestas áreas predominam sítios, chácaras de lazer e turismo local, APPs e a APA do Corumbataí. As diretrizes visam preservar e proteger os mananciais, as APPs e o patrimônio ecológico existente e indicam ainda que as áreas de relevância ambiental sejam inseridas no Sistema Nacional de Unidades de Conservação (SNUC) e no Sistema Estadual de Unidades de Conservação (SEUC) (SÃO CARLOS, 2016).

Por fim, as zonas 9A - Multifuncional Rural e 9B - Multifuncional Rural e de Proteção Hídrica (figura 43) apresentam maior vocação às atividades agrícolas sendo proibidas a expansão urbana e parcelamentos do solo em dimensões inferiores à $20.000 \mathrm{~m}^{2}$. Na zona $9 \mathrm{~A}$, as diretrizes apontam para o aproveitamento do potencial de lazer e turismo apresentado pelas fazendas históricas e pela paisagem natural, compatibilizando-o com a preservação ambiental e o uso agrícola. A zona 9B apresenta potenciais mananciais para o abastecimento hídrico em médio prazo, havendo assim o direcionamento de maior proteção a estas áreas.

As Áreas de Interesse Ambiental (AIA) ${ }^{110}$ (figura 44) foram revistas em relação ao Plano Diretor de 2005. Houve um aumento significativo das áreas demarcadas devido à inclusão de quase a totalidade das margens dos córregos internos ao perímetro urbano e da Zona de Expansão Urbana, das SAPREs 1 e 2 (referentes à Lei dos Mananciais). Também foram incluídas as áreas públicas de Sistema de Lazer, os canteiros centrais e parques lineares, os maciços de vegetação nativa demarcados e as APPs e, faixas verdes complementares junto aos corpos d'água das Zonas 6 e 7.

O Plano (2016) aponta, além da proteção e da recuperação destas áreas, a sua relevância para a adequada drenagem de água pluvial, bem como a destinação para a criação de Parques Lineares e Unidades de Conservação. Por mais que muitas AIA estejam ocupadas $^{111}$ por edificações ou avenidas marginais, ainda é possível visualizar um potencial Sistema de Espaços Livres pela conectividade e fruição que possuem estas áreas, mas especialmente graças à sua gravação pela legislação.

\footnotetext{
${ }^{110}$ Áreas de Interesse Ambiental (AIA) correspondem às Áreas Especiais de Interesse Ambiental (AEls Ambiental) do Plano Diretor Participativo (2005) com os acréscimos enumerados.

111 Nas Disposições Finais, o Plano Diretor dispensa a exigência de APP "nas áreas onde estas faixas estão ocupadas com urbanização legalmente consolidadas" (SÃO CARLOS, 2016, Art. 226). 


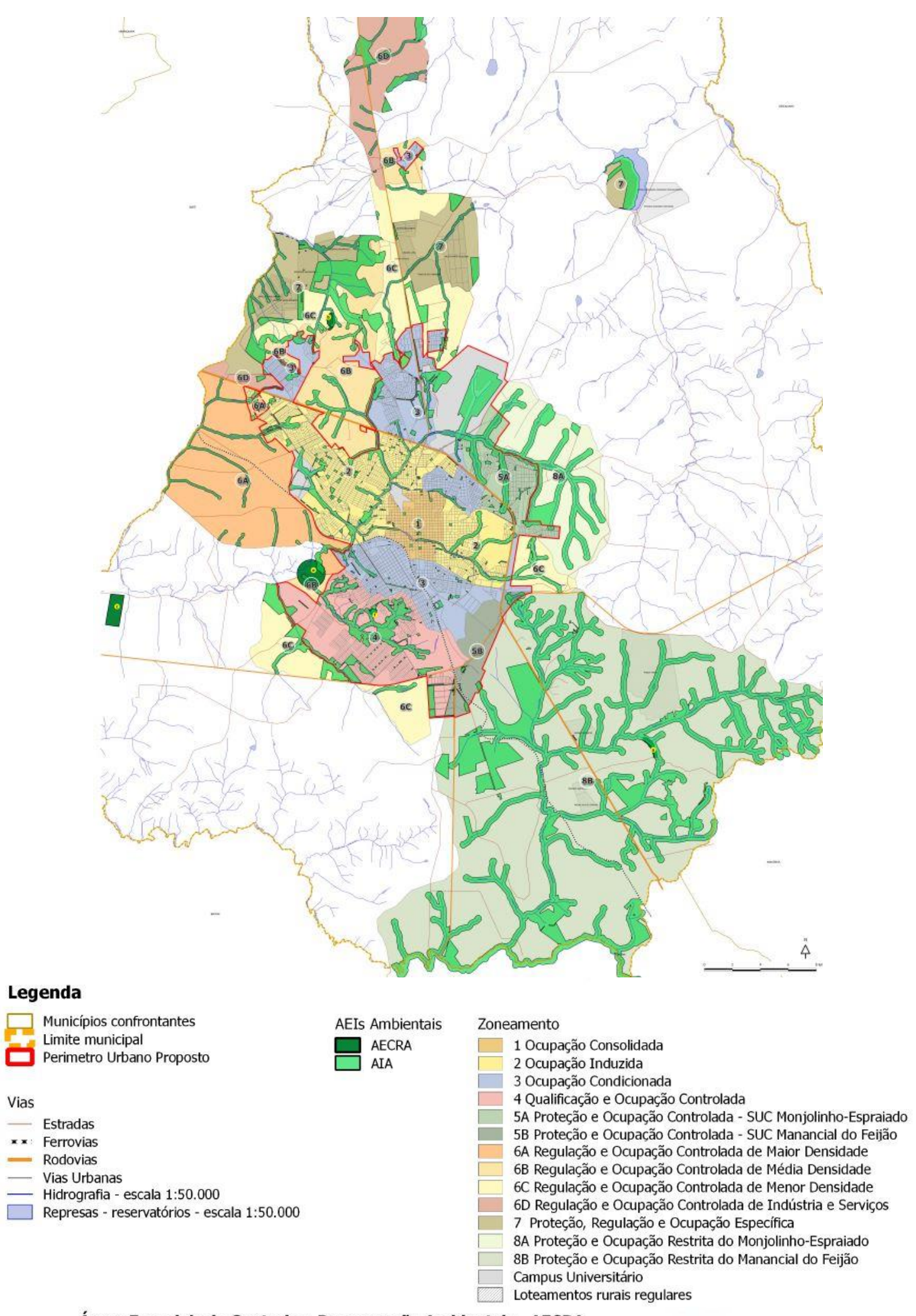

Áreas Especiais de Controle e Recuperação Ambientais - AECRA

a Do antigo lixão (sítio Santa Madalena), na zona 8 B

b Do antigo aterro sanitário (Fazenda Guaporé), na zona $6 \mathrm{C}$

c Do atual aterro sanitário (próximo à rodovia Luiz Augusto de Oliveira), na zona $9 \mathrm{~A}$

e Da estação de Tratamento de Esgoto do Monjolinho (num raio de 500 metros a partir do centro geométrico de sua implantação), entre as zonas $6 \mathrm{~B}$ e $9 \mathrm{~A}$

Figura 44: Mapa das Áreas de Interesse Ambiental.

Fonte: SÃO CARLOS, 2016. 
No mapa acima (figura 44) pode-se ver também as Áreas Especiais de Controle e Recuperação Ambientais (AECRA), locais que passaram por distintas intervenções antrópicas causadoras de danos ambientais, como aterros sanitários, aterros de resíduos da construção civil, áreas de extração de rochas e Estação de Tratamento de Esgoto, e que, portanto, necessitam ser recuperadas, podendo, de acordo com o Plano, transformar-se em áreas de preservação ambiental e parques.

Dentre as Áreas de Especial Interesse Social (AEIS) observam-se situações de moradias populares precárias, irregulares e em situação de risco geológico devido a registros de deslizamentos (ao Sul da cidade), além de diversas ocupações de APPs ${ }^{112}$. Para os casos em que forem comprovados riscos para a população, o Plano (2016) indica ações de remoção, cadastro para eventual reassentamento, proteção destas áreas e destinação para uso socioambiental de interesse público.

Podem-se citar outras áreas especiais trazidas nesta legislação como as Áreas de Interesse Turístico, Histórico, Cultural e Ecológico, que correspondem às Fazendas históricas localizadas na zona rural; e as Áreas Especiais de Proteção Paisagística, com relevantes paisagens naturais e antrópicas e com potencial turístico, como o vale e a bacia do Rio Quilombo, as margens norte e nordeste da Represa do Bom Retiro (Represa do 29), a Usina do Capão Preto e o Distrito de Santa Eudóxia (SÃO CARLOS, 2016).

Quanto ao parcelamento do solo para fins urbanos, a porcentagem de $18 \%$ referente à doação de áreas públicas ${ }^{113}$ foi redistribuída devido a inclusão da Área Patrimonial ${ }^{114}$ de $4 \%$, ocorrendo a diminuição para 7\% de Sistema de Lazer e para 7\% de Área Institucional. 0 Sistema de Lazer foi definido como "área destinada ao sistema de áreas livres públicas, visando à implantação de praças, parques, áreas com equipamentos de lazer, culturais ou esportivos, como playgrounds, quadras, campos de jogos, dentre outras" (SÃO CARLOS, 2016, Art. 132). Há exigências quanto à área mínima, que no caso do Sistema de Lazer é de $500 \mathrm{~m}^{2}$,

\footnotetext{
${ }^{112}$ Cabe lembrar que a ocupação de APPs não é uma ação exclusiva da população da baixa renda, ocorrendo inclusive pela implantação do sistema viário pelo poder municipal, como foi apresentado no início deste Capítulo. 113 Não entram no cálculo de áreas públicas, as APPs e faixas de servidão ao longo das linhas de transmissão de energia elétrica, conforme já indicado no Plano Diretor de 2005. Houve a inclusão das áreas de Reserva Legal averbadas; das rotatórias e os canteiros centrais de avenidas; e das faixas de domínio de rodovias, ferrovias (SÃO CARLOS, 2016, Art. 133).

114 "Área Patrimonial: área pública que integrará o patrimônio municipal sem afetação de uso, a não ser no caso da destinação da mesma à Fração de Interesse Social, podendo ser destinadas a usos de interesse público, social ou comunitário, e sendo vedada a venda da mesma" (SÃO CARLOS, 2016, Art. 132).
} 
e quanto ao formato que permita a inscrição de um círculo com diâmetro de $20 \mathrm{~m}$ (há exceções previstas). Apesar da utilização do vocábulo "Sistema" de Lazer, não há referência à formação de um Sistema de Espaços Livres no sentido de espaços livres diversos e articulados e, principalmente, orientadores do planejamento urbano.

No entanto, o Plano Diretor atual (2016) prevê as Faixas Verdes Complementares (FVC), que já eram exigidas pela Lei da APREM nas áreas que correspondem às zonas 5 e 8 e que passam a ser exigidas para o parcelamento em glebas com APPs das outras zonas, porém com largura inferior. As FVC

se constituem em faixas contíguas às APPs para fins de ampliar a faixa de proteção ambiental dos corpos d'água, incrementar a permeabilidade do solo urbano, servir de suporte para a implantação das bacias de retenção de águas pluviais, ou para a implantação de projetos específicos como Parques Lineares (SÃO CARLOS, 2016, Art. 137).

As críticas ao Plano Diretor de 2016 referem-se ao aumento expressivo das áreas urbanizáveis em todas as direções, contrariando os princípios de cidade compacta tão relevantes ao se discutir a expansão urbana sobre áreas ambientalmente frágeis e as desigualdades socioespaciais. De acordo com a revisão do Plano Diretor realizada pela equipe do IAU em 2011, o Plano Diretor de 2005 contribuiu para a ocupação dos vazios urbanos através da Outorga Onerosa de Alteração de Uso do Solo. Este instrumento estabeleceu a contrapartida correspondente a $5 \%$ do valor de mercado do imóvel sujeito ao parcelamento para fins urbanos em zonas passíveis de expansão externas ao perímetro urbano (no Plano Diretor de 2005, Zona 4 e Zona 5), conseguindo-se deste modo conter o espraiamento da cidade. O enfrentamento da ociosidade dos vazios urbanos e a busca por alternativas para a expansão da cidade não foram as questões centrais da discussão final que aprovou o Plano atual (SCHENK; PERES; FANTIN, 2016).

A pauta do desenvolvimento sustentável e do direito ao ambiente equilibrado, que na revisão do IAU aparecia pela compreensão da bacia hidrográfica como determinante ao macrozoneamento e ao zoneamento, tão relevante por incluir elementos ambientais e recursos naturais, por abranger o território municipal na sua totalidade, bem como pelo potencial de articulação intermunicipal, não aparece como motivação do Plano Diretor atual. Também não há referências às ferramentas de Zoneamento Ambiental e de Estudo Prévio de 
Impacto Ambiental (EIA) presentes no Plano de 2005, restando apenas o Estudo Prévio de Impacto de Vizinhança (EIV) como regulação prevista.

Pela ótica dos agentes do mercado imobiliário a expansão ao Sul da cidade, local caracterizado pela grande fragilidade socioambiental, seria solucionada pela técnica e se justificaria pela possibilidade de aquisição de imóveis pela população de baixa renda, devido ao menor valor destes terrenos pertencentes aos pequenos proprietários. No entanto, nessa região observa-se pouco investimento em infraestrutura pelo poder público, que direciona recursos para a área Norte da cidade. A urbanização ao Sul se configura pela parceria entre poder público e agentes privados, representada pela construção de empreendimentos habitacionais do Programa Minha Casa Minha Vida faixa 1, reafirmando a histórica segregação socioespacial. Nesses novos bairros dispersos da mancha urbana, além do enfrentamento dos problemas referentes à mobilidade e à qualidade ambiental, observa-se a carência de espaços livres públicos qualificados, como colocam Schenk, Peres e Fantin (2017, p. 82-83):

\begin{abstract}
Em relação ao Sistema de Espaços Livres que vem sendo produzidos a partir desse processo, alguns aspectos podem ser observados. As implantações realizadas na periferia sul da cidade, constrói modelos bastante conhecidos da Habitação Social, casas isoladas em pequenos lotes, ruas que se resumem ao leito carroçável. Aquilo que aparece nos projetos como praça são espaços livres desqualificados a espera de projeto ou construção. O principal fato geográfico desse território, que se constitui em vazio urbano, cuja geografia desvela um vale de grande potencial paisagístico, remanesce à espera de um projeto de parque que reuniria, dada sua escala, qualidades de conservação, desempenho infraestrutural e de recreação.
\end{abstract}

Este cenário difere da área Norte, onde se localizam condomínios fechados de classe média e alta, shopping center, galerias comerciais, parques tecnológicos, complexo de lazer privado, universidades, havendo maior investimento público em infraestrutura e equipamentos urbanos ${ }^{115}$ e investimento privado. Quanto aos espaços livres, aqueles internos aos empreendimentos são bem qualificados, enquanto os externos geralmente não apresentam tal qualificação.

Os problemas urbanos ambientais em São Carlos resultam de escolhas de planejamento, estipuladas para atender aos interesses das classes dominantes. Na atualidade,

\footnotetext{
115 Observam-se também mudanças na paisagem devido a implantação do Hospital Escola da UFSCar e do Campus 2 da USP, que provocaram a valorização do entorno e atraíram condomínios de maior padrão (SCHENK, PERES, FANTIN, 2017).
} 
estas escolhas estão atreladas às alianças entre os setores imobiliários e o poder público, sob o discurso da geração de oportunidades sociais (SCHENK, PERES, FANTIN, 2016), mas que na verdade reafirmam os padrões de constituição da forma urbana e suas implicações.

Em janeiro de 2020 São Carlos foi atingida por intensas chuvas em curto período de tempo, que mais uma vez causaram enchentes nos locais já conhecidos: na área central na região da baixada do Mercado Municipal; no conjunto habitacional da CDHU, na área Sul da cidade; na Praça Itália; na rotatória do Cristo Redentor, entre outros. Os prejuízos foram maiores na área central, onde a água atingiu 1,5 m de altura acima do nível das ruas, invadindo muitas lojas e resultando em prejuízos para os comerciantes e destruição para a cidade (figura 45).

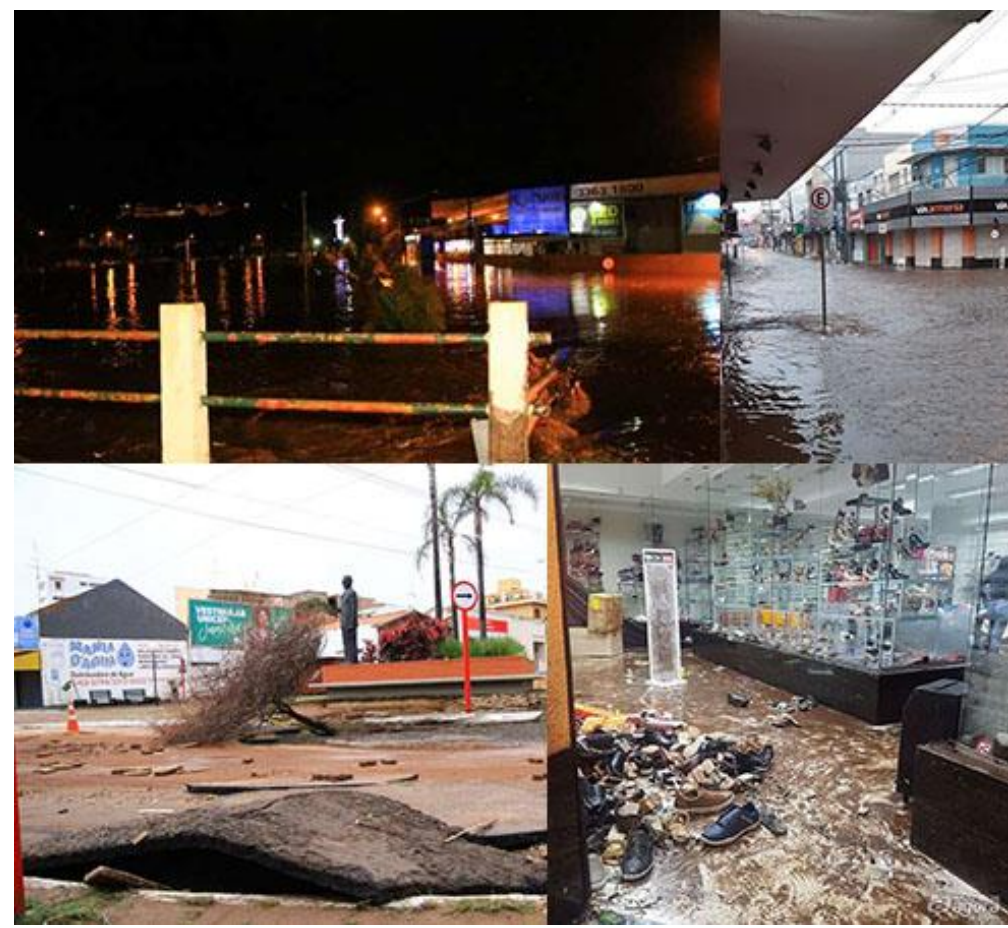

Figura 45: Fotos da enchente em 2020 e seus danos.

Fonte: Homepage São Carlos Agora ${ }^{116}$ e Rede Sanca Web TV ${ }^{117}$.

Este tipo de notícia é recorrente e esperado na cidade. O conflito com o meio físico foi construído ao longo dos anos através de planejamento e projetos que previram

\footnotetext{
${ }^{116}$ Disponível em: <https://www.saocarlosagora.com.br/cidade/centro-de-sao-carlos-fica-destruido-apos-achuva/121803/?fbclid=IwAROhkIC1NWgZanKbSFJ6Ubsuyj5ZyYpZLMt9CcijvwsjmzqpPSSYpC47XxM>. Acesso em: 25 jan. 2020.

${ }^{117}$ Disponível em: <https://www.radiosanca.com.br/2020/01/02/sao-carlos-registra-a-primeira-enchente-em2020/>. Acesso em: 25 jan. 2020.
} 
impermeabilizações e trato dos corpos de água através da engenharia cinza: retificação, canalização e, em alguns casos, tamponamento.

Nesta dissertação, critica-se a maneira pela qual foram formados os diversos espaços livres da cidade. Ao longo deste Capítulo foram apresentadas as ações e as consequências negativas do modelo de planejamento adotado, que implicam desde a oneração do poder público ao agravamento dos conflitos socioambientais. Deste modo, o estoque de espaços livres do município de São Carlos, composto pelos espaços não edificados na malha urbana, bem como pelo vasto território rural e pelas áreas de transição por onde segue a expansão urbana, constituem potenciais geradores de um Sistema de Espaços Livres. Essa articulação entre espaços referenda uma ação historicamente constituída no campo disciplinar da Paisagem: o Sistema de Espaços Livres, que reúne questões associadas à infraestrutura, lugares de recreio, propiciando convívio, lazer e mobilidade. Nesse contexto, o planejar com a paisagem coloca-se como estratégia metodológica alternativa de planejamento, abrangendo a complexidade inerente à paisagem, e com a intenção de trazer qualidade de vida para a cidade. 


\section{PLANEJAR COM A PAISAGEM: UM SISTEMA DE ESPAÇOS LIVRES PARA SÃO CARLOS}

Esse capítulo explora a possibilidade de contato entre o planejamento urbano e a paisagem, retomando conceitos estabelecidos pelo campo disciplinar da Arquitetura da Paisagem, que teve o pioneirismo de Frederick Law Olmsted no final do século XIX. Os projetos deste arquiteto da paisagem conciliavam técnica, arte, estética e salubridade através de projetos de infraestruturas de drenagem vinculados ao tratamento paisagístico, que proporcionavam lugares de sociabilidade e contato com a natureza, contribuindo para a qualidade de vida na cidade industrial. Essa matriz teórica e prática foi sendo construída desde aquele momento, reiterando questões que se consolidaram pela historiografia do campo disciplinar, que nesta dissertação foram apresentadas principalmente a partir de McHarg (1969), Spirn (1984) e Hough (1984) ${ }^{118}$. As discussões que usualmente são conflituosas no desenvolvimento urbano e que envolvem os processos naturais (geológico, hidrológico e biológico etc.) e os processos humanos (socioeconômico e cultural) são objeto do campo disciplinar da Paisagem e parte fundamental desta investigação.

O fio condutor deste trabalho - Planejar com a Paisagem - pretende abranger elementos desconsiderados pelo planejamento urbano tradicional ou tratados de maneira fragmentada pelos planos territoriais. Planificar o uso e ocupação do solo é uma tarefa complexa e envolve questões das mais diversas ordens, que são abordadas de maneira setorizada pelas leis existentes e, nem sempre são eficientes para atender às necessidades sociais e ambientais.

É comum o entendimento da natureza como algo separado da cidade e associado às áreas naturais, que, de acordo com este entendimento, deveriam ser protegidas e isoladas. Spirn (1995) e Hough (1998) alertaram para os prejuízos desta visão no sentido de um desenvolvimento urbano em congruência com a natureza, assim como Besse (2014) apontou posteriormente.

\footnotetext{
${ }^{118}$ Anos das primeiras edições dos livros: 'Projetar com a Natureza' de lan McHarg; 'O jardim de Granito' de Anne Spirn; 'Natureza e Cidade' de Michael Hough, referências apresentadas no Capítulo 1.
} 
Enfim, a paisagem é convocada de forma privilegiada quando se trata de imaginar soluções que permitam o "encontro", por assim dizer, entre a cidade e a "natureza". As preocupações ecológicas e ambientais são hoje determinantes, como sabemos. A natureza já não significa mais apenas o "outro" da cidade, essa coisa verde mais ou menos selvagem que é encontrada no exterior do universo urbano. A natureza está na cidade, e está presente, por um lado na forma de preocupações quanto à qualidade das águas e do ar, por exemplo, por outro lado, na forma de projetos de parques e jardins públicos e, enfim, na forma de reflexões e experiências relativas à diversidade das essências vegetais que podem ser instaladas nela de forma sustentável. Em outros termos, a cidade é, hoje, um meio natural híbrido, de um tipo particular (BESSE, 2014, p. 58-59).

Ao considerar a paisagem no planejamento das cidades e tendo no horizonte o compromisso ético presente desde a origem do campo de conhecimento da Arquitetura da Paisagem, que se compromete a planejar e projetar esses espaços livres fundamentais à vida, caminha-se para a obtenção de um meio urbano mais equilibrado, mais justo, diversificado e com potencial qualidade no desenho desses espaços, graças à perspectiva de construção de lugares mais integradores de suas funções e usos.

O termo paisagem admite diversos significados, sendo empregado por diferentes disciplinas (artes, literatura, ciências sociais, filosofia, geografia, ecologia, arquitetura e urbanismo, agronomia entre outras), e constituindo um vasto campo de investigação, que se ampliou na medida em que as ações humanas aumentaram sua abrangência e complexidade sobre a superfície terrestre. Atualmente a paisagem adquire relevância social e política por se relacionar não só aos questionamentos acerca da proteção dos meios naturais e aos modo de uso e ocupação dos territórios, como também aos questionamentos sobre identidade dos lugares.

$\mathrm{Na}$ pesquisa dos significados da paisagem, os autores selecionados apresentam algumas dimensões possíveis e não definições rígidas, utilizados aqui de modo a fundamentar esta estratégia metodológica. Assim, esta dissertação também pretende contribuir na construção dos diferentes modos de olhar a temática, de forma a "explicitar as abrangências, convergências e afastamentos no intuito de colher, entre conceitos utilizados em campos disciplinares diferentes, aqueles que mais auxiliam na aplicação" (SCHLEE et al., 2009, p. 228). 
Schlee et al. (2009), com base na divisão estabelecida por Maria Angela Leite no artigo "A paisagem, a natureza e a natureza das atitudes do homem"119, sugeriram duas vertentes: a primeira relaciona a paisagem à sua essência material, objetiva, na qual se encaixam as dimensões, itens (a), (b) e (e) apresentadas a seguir; a segunda relacionada a paisagem à sua essência simbólica, à sua experimentação, representada pelas dimensões (c) e (d).

(a) dimensão morfológica, na qual a paisagem é traduzida como um conjunto de configurações formais, derivadas da natureza e da ação humana; (b) dimensão funcional, relativa à organização, porque suas partes guardam relações entre si; (c) dimensão histórica, na medida em que é produto das transformações ocorridas ao longo do tempo; (d) dimensão simbólica, pois a paisagem carrega significados que expressam valores, crenças, mitos e utopias; e (e) dimensão dinâmica, a relacionar os padrões espaciais aos processos que lhes deram origem (SCHLEE et al., 2009, p. 232-233).

No livro "O gosto do mundo: exercícios de paisagem", tendo o objetivo de explicitar os processos ativos na transformação da paisagem, Besse (2014) descreveu as "cinco portas da paisagem", que são algumas das problemáticas paisagísticas contemporâneas, evidenciadas na citação:

Assim, a paisagem é considerada como uma representação cultural (principalmente informada pela pintura), como um território produzido pelas sociedades na sua história, como um complexo sistêmico articulando os elementos naturais e culturais numa totalidade objetiva, como um espaço de experiências sensíveis arredias às diversas formas possíveis de objetivação, e como, enfim, um local ou um contexto de projeto (BESSE, 2014, p. 12).

Do ponto de vista subjetivo Besse (2014, p. 13) descreveu a paisagem: "Ela é um tipo de grade (retícula) mental, um véu mental que o ser humano coloca entre ele mesmo e o mundo, produzindo, com essa operação, a paisagem propriamente dita". A paisagem também é uma experiência que proporciona o contato com formas, texturas, cores e dinâmicas e que pressupõe a presença do corpo e sua relação com o entorno, por exemplo, através da caminhada.

Para Besse (2014) o arquiteto da paisagem atua na "porta" descrita como "projeto da paisagem", sendo sua atuação essencial revelar a realidade intrínseca a esta paisagem, ou seja, explicitar seus elementos constituintes, seus padrões, suas relações presentes no território, mas que não são percebidos facilmente.

119 LEITE, Maria Angela Faggin P. A paisagem, a natureza e a natureza das atitudes do homem. Paisagem e Ambiente: Ensaios, São Paulo: FAUUSP, n. 4, p. 45-66, 1992. 
Em outros termos, o projeto inventa um território ao representá-lo e ao descrevê-lo. Entretanto, essa invenção é de natureza singular: pois o que é inventado já está, ao mesmo tempo, presente no território, mas como não visto e não sabido até então. A invenção revela o que já estava aí, ela revela e desvenda um novo plano de realidade. Mas não teríamos visto essa realidade se não tivesse sido desenhada e pensada. Como se a inteligência humana viesse inserir-se no movimento do mundo para destacar nele certos elementos e reatar as ligações entre esses elementos, como se a inteligência humana participasse, no fundo, da criação do mundo (BESSE, 2014, p. 61-62).

$\mathrm{O}$ autor colocou ainda que $\mathrm{o}$ arquiteto da paisagem desempenha papel significativo ao intervir em espaços configurados como "entre", bordas, passagens, intervalos, nos quais se visualiza o "encontro entre o urbano e o não urbano, entre o edificado e o não edificado, entre o fechado e o aberto, entre o mundo humano e o mundo natural e, talvez mais radicalmente, entre o 'dentro' e o 'fora'"' (BESSE, 2014, p. 59). Assim, a problemática da Arquitetura da Paisagem consiste em reconectar a cidade e seus elementos naturais, seu território, seu contexto, ação designada por este autor como recosturar ligações, "tecer com", que rementem ao aqui proposto: planejar com a paisagem.

É bom lembrar que os problemas de organização da distribuição espacial da apropriação dos recursos no meio urbano são manifestamente, em sua particularidade, de configuração, problemas de paisagem. Desse modo, então, a paisagem deixa de ser uma abstração a serviço das ideologias para passar a fazer parte das categorias cuja análise pode auxiliar no estudo e na compreensão dos modos de apropriação do espaço e também contribuir com a indicação de alternativas de modos de apropriação mais abrangentes e inventivos (SANTOS, 2003, p. 111-112).

Nesse sentido, Santos (2003) definiu a paisagem urbana como produto e meio das relações entre o suporte físico e as intervenções antrópicas em um movimento contínuo, ou seja, como fisionomia resultante do uso e ocupação do solo, tanto em relação à sua forma, quanto à sua distribuição e localização.

$\mathrm{Na}$ atualidade, não basta descrever as paisagens, o desafio contemporâneo é procurar compreender as complexas relações que as conformam, movimentam, transformam e engendram identidades, conflitos, representações, apropriações, ideologias. Nesse sentido, no âmbito das discussões relacionadas aos sistemas de espaços livres, nossa reflexão pontua a paisagem como produto que incorpora os processos biofísicos e os processos sociais nela refletidos, em diversos tempos e escalas, e apresenta elementos de integração ou fragmentação territorial, criando e recriando formas, funções e fluxos, com funções ecológicas diversas, em estágios diferentes de intervenção humana (SCHLEE et al., 2009, p. 235). 
O crescente interesse pelas questões ambientais, juntamente com as questões sociais, cria bases para a discussão sobre os espaços livres nas cidades brasileiras. Conforme apresentou-se nesta dissertação, é possível afirmar que parcela considerável de nossas cidades se desenvolveu sob a égide tecnocrata ${ }^{120}$, tendo as dimensões sociais e humanas frequentemente desconsideradas e, no planejamento contemporâneo, segue sendo urbanizada sob lógicas de mercado, promovendo decisões que privilegiam acumulações desiguais e distribuições parciais. Nesse contexto, os espaços livres públicos ligados ao sistema viário, praças e parques são relevantes na construção das cidades mais agradáveis.

Os espaços livres de um território, ou seja, aqueles sem a presença de edificações, verdejados ou não (MAGNOLI, 1982), podem assumir um papel significativo na minimização dos problemas urbanos decorrentes do planejamento inadequado, redirecionando o desenvolvimento da cidade. Tais espaços deixam de ter caráter residual para reivindicar o papel de protagonistas, participando ativamente na intervenção urbanística (TARDIN, 2008). Em um território bastante urbanizado os espaços livres podem ser entendidos como oportunidades para estruturar a malha urbana de forma favorável ao meio físico e aos interesses socioeconômicos, prevendo-se os usos mais adequados para cada espaço. Entendese assim que os espaços livres de uma paisagem desempenham múltiplas funções, desde aquelas relacionadas à infraestrutura urbana (circulação, drenagem, lazer etc.) até aquelas relacionadas ao conforto térmico, à conservação e proteção de ecossistemas, bem como aquelas referentes à sociabilidade e à experiência estética.

O planejamento dos espaços livres nas cidades ainda é incipiente, observando-se a dificuldade de ações coordenadas e articuladas devido à multiplicidade de interesses de grupos sociais, agentes produtores e gestores, além de descontinuidades administrativas (QUEIROGA, 2011). Assim, muitas vezes ocorre uma visão fragmentada em termos de plano e gestão, em que as instituições e leis não dialogam e acabam por acarretar um descompasso entre o planejamento urbano e o planejamento ambiental. Existem disposições de lado a lado que poderiam ser potencializadas se alinhadas, contudo, construir essa congruência é um grande desafio, pois estamos em campos de conhecimento distintos e que pensam suas ações a partir de lógicas e valores também distintos. Como foi abordado no segundo Capítulo, o

${ }^{120}$ No sentindo de que os problemas de uma cidade se resolvem apenas pela técnica. 
descompasso entre os planejamentos urbano e ambiental persiste, e quando há alguma política pública em relação aos espaços livres, ela é parcial, faltando a articulação entre as necessidades relacionadas à habitação, ao transporte público e aos equipamentos urbanos.

Silva et al. (2014) colocou, com base no texto de Acselrad ${ }^{121}$, que a paisagem urbana adquire diferentes valores para grupos sociais distintos, gerando conflitos que dificultam a implantação do Sistema de Espaços Livres (SEL).

Nesta primeira década do século XXI, ao analisar os espaços livres de algumas cidades, constata-se que raramente existe uma gestão ou uma proposta de ação que considere os elementos como parte de um Sistema. Parece haver um descompasso entre as demandas dos diferentes grupos sociais e ações públicas pontuais que transformam os elementos do Sistema (SILVA et al., 2014, p. 15).

No Brasil, o poder público tem historicamente como prioridade o planejamento do sistema viário (SOMEKH; CAMPOS, 2002), espaço livre que privilegia o automóvel particular e relega para segundo plano o transporte público e para um terceiro plano o pedestre e o ciclista. Esse padrão de planejamento não responde à demanda da população por lugares de sociabilidade e, muitas vezes, não atende a todo espectro de necessidades funcionais de cada lugar. Contudo, se integrado ao Sistema de Espaços Livres (SEL), o sistema viário pode adquirir qualificações - arborização adequada, estares, ciclovias - que os transforme em espaço de sociabilização para além da função já consolidada do deslocamento motorizado.

O status de infraestrutura urbana que os espaços livres podem adquirir, em especial se associados entre si, sistemicamente, através de um desenho urbano ambiental que articule parques, praças, bosques, ruas arborizadas, ciclovias, não vem sendo explorado por planejadores e gestores das cidades brasileiras. Essa perspectiva é pouco utilizada a despeito de seus benefícios, uma alternativa consistente contra recorrentes desastres socioambientais, como no caso de enchentes e deslizamentos de terra.

A iniciativa privada, materializada nas cidades na forma de empreendimentos de grandes proporções (condomínios fechados, shopping centers etc.), quando assume o papel de provimento de espaços livres, em muitos casos, os apresentam como espaços privados ou com acesso ao público altamente restringido. Queiroga (2011) ressaltou que existe uma

\footnotetext{
${ }^{121}$ ACSELRAD, Henri (org.). Cartografias sociais e território. Universidade Federal do Rio de Janeiro, Instituto de Pesquisa e Planejamento Urbano e Regional (UFRJ-IPPUR), Rio de Janeiro, 2008.
} 
crescente dependência em relação ao mercado na provisão de SELs, especialmente em áreas destinadas às elites: a imagem "verde, tranquila e segura" é vendida como produto imobiliário, no entanto, frequentemente esses empreendimentos apresentam fortes impactos sociais, ambientais e paisagísticos, que são sentidos no médio prazo. Esse padrão pode ser notado nas grandes metrópoles e em cidades médias, como São Carlos, Ribeirão Preto, São José do Rio Preto, São José dos Campos, Sorocaba, entre outras.

O desafio que enfrentam cidades menores em crescimento e novas cidades está em aprender com os erros das cidades mais antigas e projetar a cidade desde o início de forma a explorar as oportunidades do ambiente natural. Este desafio é particularmente agudo nas cidades de crescimento rápido os bairros inteiros surgem da noite para o dia (SPIRN, 1995, p. 26).

Portanto, torna-se relevante observar o caráter plural presente nestes espaços livres de forma a valorizar seus atributos significativos, suas qualidades singulares, como força motriz para o planejamento urbano. Um rio, por exemplo, não é limite entre duas partes de um território ou problema à época das chuvas por ocasião de suas cheias, mas é presença marcante da fisionomia daquele território. O rio tornado visível pelo ato de planejar e projetar é um convite à apropriação, superando a visão negativa e de barreira à ocupação. As intervenções padrão como retificação, canalização, impermeabilização da várzea causam profundas transformações na paisagem, e terminam, muitas vezes, por configurar áreas de menor interesse para o uso (SANTOS, 2003). Esse tipo de intervenção desconsidera diversas possibilidades de uso e aproveitamento inerentes aos espaços livres.

Diante da complexidade urbana contemporânea parece oportuna uma aproximação aos espaços livres não somente a partir de sua função ecológica ambiental, fundamental, mas insuficiente, pois também existe a demanda por lugares de convívio público e sociabilização com qualidade estética e, atrelados à estrutura urbana.

A abordagem sistêmica dos espaços livres é pertinente para essa multiplicidade presente na temática da paisagem, tornando possível pensar interconexões entre formas e apropriações. O SEL busca estratégias para articular os fragmentos de espaços livres em diversas escalas e com diversas funcionalidades, qualificações estéticas e fundiárias (QUEIROGA, 2011). Estes espaços estabelecem, ainda que potencialmente, relações entre si e mesmo sem conexão física afetam-se reciprocamente. 
A noção de "sistema" remete a um conjunto de elementos interconectados, de modo a formar um todo organizado. É uma definição a permear várias disciplinas, como biologia, medicina, engenharia, informática e administração. Sistema significa combinar, ajustar, formar um conjunto. Um sistema consiste de componentes, entidades, partes ou elementos e as relações entre eles. A integração entre tais componentes pode se dar por fluxo de informações, matéria e energia (SCHLEE et al., 2009, p. 238).

A compreensão do Sistema de Espaços Livres e das camadas que podem estar presentes em uma paisagem pressupõe o entendimento da importância desses espaços para a qualidade de vida na cidade, associados a uma solução sustentável, ecológica e econômica para os problemas urbanos.

O desenvolvimento de metodologias que reconheçam e analisem os espaços livres como estruturadores do espaço urbano permite destacar e desenvolver o modo pelo qual eles possam ser utilizados. Porém, a isso se interpõem questões que fundamentam a Arquitetura da Paisagem: não se trata apenas de perceber fragilidades e potencialidades ambientais presentes, mas de trazer e provocar a participação de informações de naturezas estéticas e culturais, bem como sociais e políticas.

\subsection{Uma Estratégia Metodológica para Planejar com a Paisagem}

A estratégia metodológica em desenvolvimento considera a complexidade intrinsicamente ligada à polissemia da Paisagem (BESSE, 2014) e se baseia no campo disciplinar da Arquitetura da Paisagem, que orienta este processo visando uma ação propositiva. Esta estratégia encontra a demanda contemporânea por um desenvolvimento humano sustentável, procurando minimizar conflitos entre processos naturais e antrópicos. Para tanto, reconhece-se e resgata-se as referências existentes, aplicando-as ao contexto brasileiro atual.

Por ter a paisagem como motor do planejamento urbano, esta estratégia incorpora aspectos inerentes ao termo, tendo como característica a transversalidade, pois busca aproximação de campos de conhecimento (interdisciplinaridade) relacionados a paisagem e almeja a integração entre os agentes dos diferentes setores do planejamento territorial, bem como a participação social. A transversalidade se estende para a integração entre planejamento, projeto e política pública, na direção da efetividade da proposta, isto é, da 
realização do projeto e sua construção. O planejamento visa a conquista da área de projeto, esboçando o Sistema de Espaços Livres, que requisita todos os espaços livres de um recorte territorial potencialmente aptos a receber projetos. Por sua vez, a execução desses projetos deve estar atrelada à política pública, que se baseia nos cenários indicados em projeto para visualização da proposta pelo poder público e pela população.

Outra característica desta estratégia é o trânsito de escalas, reconhecendo a necessidade de articulação das escalas regional, municipal e local e buscando superar a dicotomia presente no enfoque de planejamentos e planos urbanos e ambientais. O trânsito de escalas permite a compreensão do território da macro escala, aquela relacionada ao plano e representada pelas informações contidas nas cartografias e imagens aéreas (por exemplo, na escala municipal), à micro escala, aquela do fenômeno, ou seja, aquela obtida pela experiência do corpo na paisagem, através da visita a campo em um determinado recorte territorial (escala local).

$\mathrm{Na}$ tentativa de abranger a complexidade e a transversalidade da Paisagem realiza-se o cruzamento de informações de diferentes naturezas, que contemplam os dados obtidos através de recursos gráficos como cartografias, fotografias, diagramas, croquis e cortes, bem como os dados obtidos em textos históricos, legislação, pesquisas científicas, jornais, entre outros e, ainda, os dados apreendidos através da experiência no lugar. Estas informações geralmente são representadas separadamente, por exemplo em cartografias temáticas. O cruzamento destas informações produz sínteses, que rementem à estratégia de McHarg (1969).

Essa estratégia produz novos conhecimentos específicos sobre o território, contemplando questões que usualmente não dialogam entre si no planejamento urbano tradicional. Ao articular estas informações no planejamento com a paisagem caminha-se para a construção de congruência entre os processos naturais e antrópicos, promovendo-se ao mesmo tempo qualidade de vida e proteção ambiental.

\section{Potenciais espaços livres para um Sistema em São Carlos}

Notadamente, desde a década de 1980 a cidade de São Carlos apresenta um tecido urbano descontínuo, resultante da expansão urbana ao longo dos anos, baseada em 
planejamento pouco eficiente em determinados períodos, e pouco efetivo em outros, e caracterizado pela configuração de diversos conflitos socioeconômicos e ambientais. Uma das consequências desse processo é a existência de espaços não ocupados, que oferecem um estoque de espaços livres, potencialmente conformadores de um sistema que reúna aspectos como a manutenção dos processos naturais, a infraestrutura, a mobilidade, o lazer, a contemplação e a sociabilidade.

A compreensão da paisagem original do território, bem como aquela formada ao longo do tempo até a atualidade e a visualização de um Sistema de Espaços Livres (SEL) pressupõe, para sua consolidação, a elaboração de princípios e valores acerca do entendimento da importância desses espaços para a qualidade de vida na cidade. Considerando a atual situação da expansão urbana e da qualidade dos espaços livres, a proposição de um SEL é estratégica na formação de um repertório cultural e na compreensão de seu papel na concepção de valores contemporâneos para a sociedade em termos ambientais. Nesse primeiro momento, o objetivo é trazer visibilidade para esses espaços e, a partir da sua análise, elaborar categorias para sistematizá-los, descrevendo, participando e contribuindo com um processo que vem acontecendo junto às Universidades.

A inclusão de questões socioambientais na orientação do desenvolvimento urbano de São Carlos começou a ocorrer na década de 2000, período de transformações no quadro do planejamento na Prefeitura, fruto de contatos entre esta e o corpo técnico das Universidades. As questões socioambientais foram retomadas na revisão do Plano Diretor realizada pelo Instituto de Arquitetura e Urbanismo (IAU-USP) em 2011, que adotou a bacia hidrográfica como determinante do macrozoneamento e zoneamento, devido a seu potencial articulador de elementos urbanos e ambientais e por envolver o município como um todo. Retoma-se o conceito de bacia hidrográfica, instituindo-o como recorte territorial do presente trabalho. Deste modo, as microbacias hidrográficas urbanas de São Carlos são compreendidas como unidades de leitura da paisagem e de planejamento com foco nos espaços livres espalhados pela malha urbana. A intenção é apresentar um Sistema de Espaços Livres para a cidade, desenvolvendo uma reflexão a partir das bases teóricas e contatos estabelecidos no percurso do Mestrado. 
A estratégia metodológica para Planejar com a Paisagem adotada nesta dissertação está sendo utilizada no ensino da disciplina de Paisagismo do quarto ano do curso de Arquitetura e Urbanismo do IAU-USP, na qual a autora foi monitora e sua orientadora é docente. A mesma estratégia é utilizada na prática do Grupo de Trabalho e de Planejamento dos Parques Urbanos (GTPU), coletivo de voluntários ligados às universidades, à prefeitura e outras instituições, da qual a autora participa. 0 grupo ${ }^{122}$ tinha o objetivo inicial de fomentar ações a respeito do planejamento dos sete parques urbanos indicados pela Prefeitura Municipal de São Carlos no decreto no 170/2017.

Este decreto criou os parques urbanos de proteção, lazer e educação ambiental no município de São Carlos, considerando os benefícios para a população propiciados pelo contato e presença da vegetação em ambientes urbanos. A criação dos parques, na realidade a gravação destas áreas em Decreto de Lei, tem as finalidades de proteção da vegetação remanescente; realização de pesquisa científica e de atividades de educação ambiental; uso público para atividades culturais, recreação e lazer (SÃO CARLOS, 2017). As áreas destinadas aos parques apresentados por essa lei são públicas e com vegetação significativa, critérios definidos pela Coordenadoria do Meio Ambiente para facilitar a implantação da proposta.

O Decreto consolidou o que se apresentava como oportunidade, terras doadas e outros locais na cidade com potencial uso recreacional, como parques, não existindo a preocupação de estabelecer um sistema. O GTPU adicionou o objetivo de desenvolver uma proposta de SEL, articulando esses espaços e ampliando suas potencialidades. A instituição do decreto e a participação no GTPU vieram ao encontro da intenção desta dissertação, proporcionando proveitosas trocas de informação e conhecimento ${ }^{123}$.

122 O GTPU foi criado pela Resolução 01/2017 do Conselho Municipal de Defesa do Meio Ambiente de São Carlos (CONDEMA), a partir de uma demanda do Secretário Municipal de Desenvolvimento Sustentável, Ciência e Tecnologia do Município, José Galizia Tundisi. Participam do grupo estudantes de graduação e pós-graduação do Instituto de Arquitetura e Urbanismo (IAU-USP - São Carlos) e do Departamento de Ciências Ambientais (DCam/ UFSCar), e técnicos da PMSC, sob a coordenação das professoras Dra. Renata Bovo Peres (DCam/ UFSCar) e Dra. Luciana B. M. Schenk, (IAU-USP - São Carlos). Em 2018 o grupo estudou e realizou a primeira proposta de um SEL para São Carlos e, em 2019, aprofundou seus estudos na direção da mobilidades alternativas, com foco nas ciclovias e promoveu o trânsito de escalas, realizando o planejamento de um dos parques integrantes do sistema, que contempla as margens do córrego Monjolinho a partir da rodovia Washington Luiz até o encontro com o córrego Santa Maria do Leme. As propostas foram apresentadas e discutidas com a sociedade e órgãos públicos em um seminário realizado anualmente pelo SESC pela ONG Veredas, uma das apoiadoras do grupo.

123 O SEL elaborado nesta dissertação baseia-se no material cartográfico levantado pelo GTPU e nas discussões junto ao grupo, mas difere do SEL elaborado pelo grupo, pois apresenta a visão da autora frente ao referencial 
Para alcançar o objetivo da proposição do SEL para São Carlos, foram utilizadas ferramentas que operam cartografias complexas através da tecnologia contemporânea do Sistema de Informações Geográficas ${ }^{124}$ (SIG). O SIG facilita a sobreposição de mapas temáticos e a manipulação das informações neles presentes para o reconhecimento das potencialidades e oportunidades projetuais da paisagem em tela, assim como o reconhecimento das vulnerabilidades socioambientais. Retomou-se os princípios desenvolvidos por McHarg, em que a aptidão de um lugar direciona seus usos e determina limitações à ocupação, com o objetivo de dupla proteção, ou seja, da vida humana e dos ecossistemas naturais. Paralelamente, almeja-se a proposição de espaços livres de lazer e sociabilidade distribuídos pela malha urbana, especialmente atendendo a demanda de grupos sociais de menor poder aquisitivo.

O levantamento dos espaços livres tem como referência a cartografia denominada Sistema de Recreio ${ }^{125}$, que abrange espaços livres públicos resultantes do processo de parcelamento do solo, utilizadas para atividades de lazer e recreação. O Sistema de Espaços Livres pode contemplar os espaços livres urbanos ou rurais, vegetados ou pavimentados, públicos ou privados (MAGNOLI, 1982). Como representação o SEL se constrói a partir da sobreposição de mapas temáticos, de modo que foi preciso ampliar o escopo de cartografias na direção das bases conceituais com as quais se trabalha. Considerando a complexidade em se Planejar com a Paisagem e com intenção de colher dados que auxiliem na proposição de um SEL, além dos mapas do Sistema de Recreio e dos Sete Parques Urbanos (Decreto no 170/2017), foram mobilizadas as seguintes bases de dados ${ }^{126}$ :

\footnotetext{
teórico da pesquisa de mestrado, bem como reflete a experiência junto à disciplina de Paisagismo (mencionada no texto) e junto ao próprio GTPU.

${ }^{124} \mathrm{SIG}$ é uma das Geotecnologias do Geoprocessamento, que pode ser definido "como um conjunto de técnicas relacionadas com o tratamento da informação espacial. Isso inclui a coleta de dados, seu processamento, análise e uso integrado. O Geoprocessamento permite analisar e cruzar dados oriundos de diversas fontes, facilitando a extração de informação e a tomada de decisão" (MEDEIROS, 2017).

${ }^{125}$ Não há uma padronização da nomenclatura referente aos espaços livres públicos, assim ressalta-se que o Sistema de Recreio é semelhante ao Sistema de Lazer definido pelo Plano Diretor (2016), ambos comentados no Capítulo 3.

${ }^{126}$ Arquivos no formato shapefile com dados georreferenciados, trabalhados no software QGIS versão 3.4.12, sobre imagem da cidade de São Carlos (GOOGLE SATELLITE, 2019), na projeção UTM Zona 23S e Datum SIRGAS 2000. Os mapas foram gerados na escala 1/75.000, com exceção do Mapa 1, em que a escala é 1/150.000.
} 
a) Base de dados da Prefeitura Municipal de São Carlos (PMSC, 2019): Curvas de nível (a cada 20 m); Microbacias Urbanas; Hidrografia; Malha Viária e Estradas de Ferro.

b) Base de dados da Prefeitura Municipal de São Carlos (PMSC, 2016): Sistema de Recreio; Áreas Institucionais; Equipamentos de Educação, Saúde, Lazer e Assistência Social.

c) Poligonal Histórica e Imóveis Protegidos da Fundação Pró-Memória de São Carlos (FPM/PMSC, 2017).

d) Plano Diretor Estratégico (SÃO CARLOS, 2016): Perímetro Urbano; Macrozoneamento; Zoneamento; Áreas de Especial Interesse Ambiental (AIA); Diretrizes viárias, Eixos estruturantes.

e) Lei das Áreas de Proteção e Recuperação dos Mananciais (APREM) (SÃO CARLOS, 2006): Subárea de Preservação 1 (SAPRE 1); Subárea de Preservação 2 (SAPRE 2).

f) Sistema Nacional de Cadastro Ambiental (BRASIL, 2018): Reserva Legal.

g) Plano Cicloviário Municipal (SÃO CARLOS, 2009): Ciclovias Implantadas; Ciclovias Previstas; Vias Compartilhadas; Polos de Atração de Tráfego.

h) Rotas Ciclistas (ONG Ciclismo São Carlos, 2019).

i) Linhas de Ónibus (Suzantur $\left.{ }^{127}, 2019\right)$.

Não constavam nas bases analisadas informações referentes a espaços já consolidados como parques, como o Campo do Rui e, sobretudo no quesito drenagem, informações imprescindíveis para a constituição do SEL, como os pontos de alagamentos ${ }^{128}$. Estes dados foram elaborados e disponibilizados pela autora. Em 2019, a Prefeitura designou mais uma área como parque localizada no bairro Jardim Embaré (Decreto no 6/2019), espaço livre público de lazer que já estava contemplado na cartografia de Sistema de Recreio, mas que não tinha o status de parque para a municipalidade.

\footnotetext{
127 Empresa responsável pelo transporte de passageiros através de ônibus rodoviários em São Carlos.

${ }^{128}$ Não se obteve acesso a uma cartografia oficial dos pontos de alagamentos em formato shapefile, assim, o mapa produzido pela autora tem como referências notícias sobre o assunto, as placas que alertam sobre o risco de alagamentos instaladas na cidade, e o Mapa das Criticidades do Plano Diretor de Drenagem Urbana Ambientalmente Sustentável do Município de São Carlos (SÃO CARLOS/SHS, 2011). Fonte: Homepage do G1, disponível em: <https://g1.globo.com/sp/sao-carlos-regiao/noticia/placas-sobre-risco-de-alagamentos-saoinstaladas-em-pontos-de-sao-carlos.ghtml>. Acesso em: 15 jan. 2020.
} 
A primeira etapa da estratégia metodológica consistiu na leitura da paisagem e de seus espaços livres, relacionando as informações contidas nos mapas temáticos (os dados mobilizados e os elaborados pela autora), que abrangem diferentes aspectos da paisagem, com o objetivo de revelar potencialidades e vulnerabilidades, de maneira a orientar a proposição do SEL. Nem todos os dados mobilizados estão representados graficamente ${ }^{129}$ nos mapas seguintes, porém serviram de apoio à análise, citando-se como exemplo alguns mapas do Plano Diretor (2016): Zoneamento; Diretrizes Viárias, Eixos Estruturantes etc.

Todas as cartografias foram elaboradas sobre a imagem aérea de São Carlos (GOOGLE SATELLITE, 2019) e contém a hidrografia (PMSC, 2019), em função da verificação de que grande parte dos problemas urbanos ambientais em São Carlos são decorrentes do conflito com a rede hídrica. Além disso, os cursos d'água constituem espaços de fruição e conectividade essenciais na composição do sistema. A leitura da paisagem e de seus espaços livres foi realizada a partir do recorte das microbacias hidrográficas urbanas, de forma a abranger a Macrozona Urbana (SÃO CARLOS, 2016) e suas adjacências, visando orientar da expansão urbana.

No mapa 1, observam-se as microbacias hidrográficas urbanas em relação ao Macrozoneamento Municipal (SÃO CARLOS, 2016). Apresenta-se a localização do recorte territorial, retângulo no qual se inscreve grande parte da Macrozona Urbana e suas adjacências.

\footnotetext{
${ }^{129}$ Por uma questão de organização dos dados e otimização visual, optou-se por não apresentar todos os mapas do Plano Diretor (2016). No entanto, alguns desses mapas foram mostrados e analisados no Capítulo 3.
} 


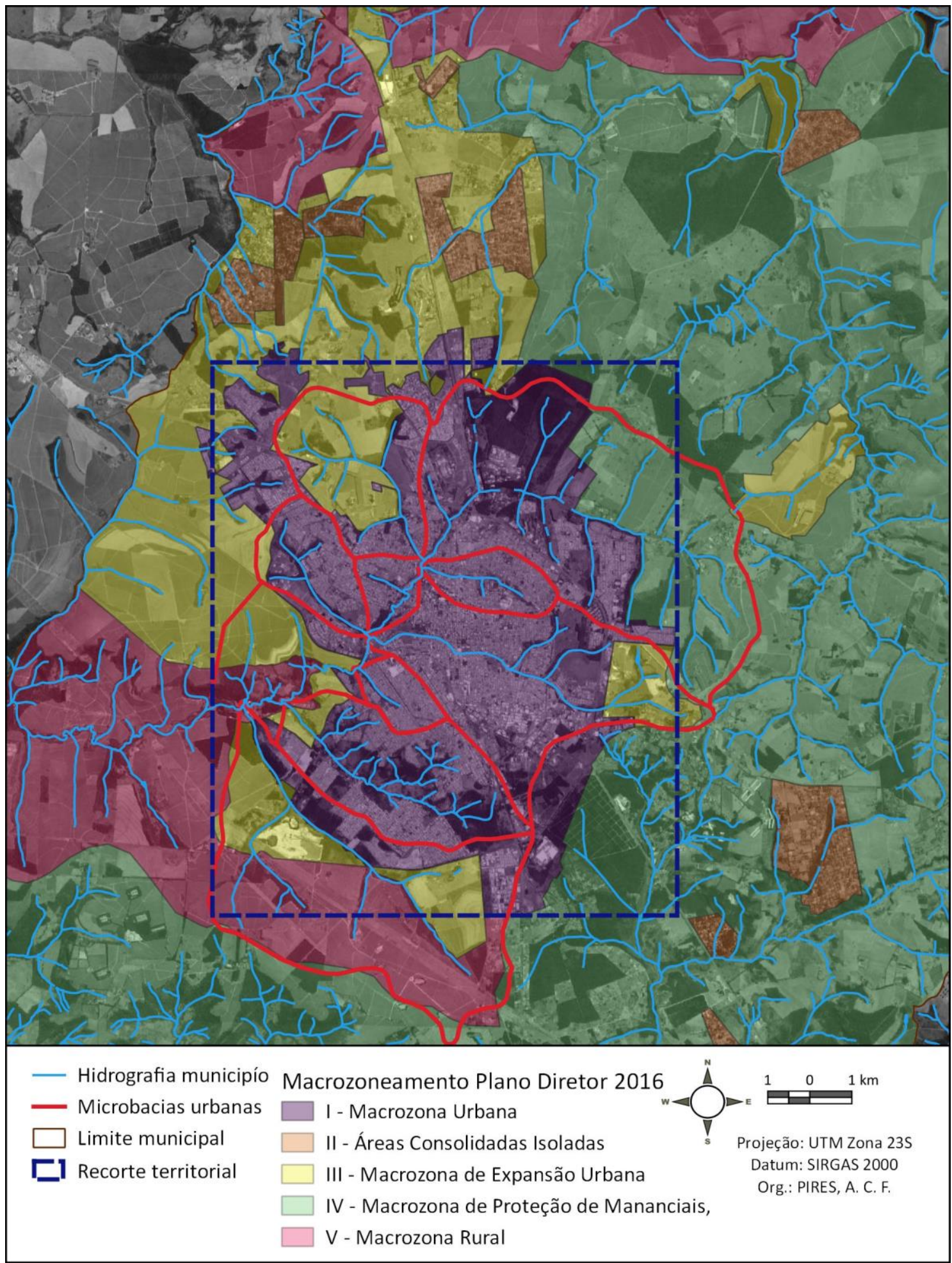

Mapa 1: Imagem de São Carlos, Hidrografia, Microbacias Hidrográficas, Macrozoneamento Municipal.

Fonte: Elaborado pela autora com base em Google Satellite, 2019; PMSC, 2019; SÃO CARLOS, 2016. 
Os mapas seguintes foram elaborados no recorte territorial escolhido ${ }^{130}$ e contemplam informações de diferentes naturezas, sendo que os mapas 2, 3, 4, 5, 6 e 7 apresentam uma leitura abrangente da paisagem e os mapas 8, 9 e 10 apresentam os espaços que foram analisados.

${ }^{130}$ Optou-se também por uma escala em que se visualizasse os espaços livres de menor porte, como as praças que irão compor o Sistema de Espaços Livres. 


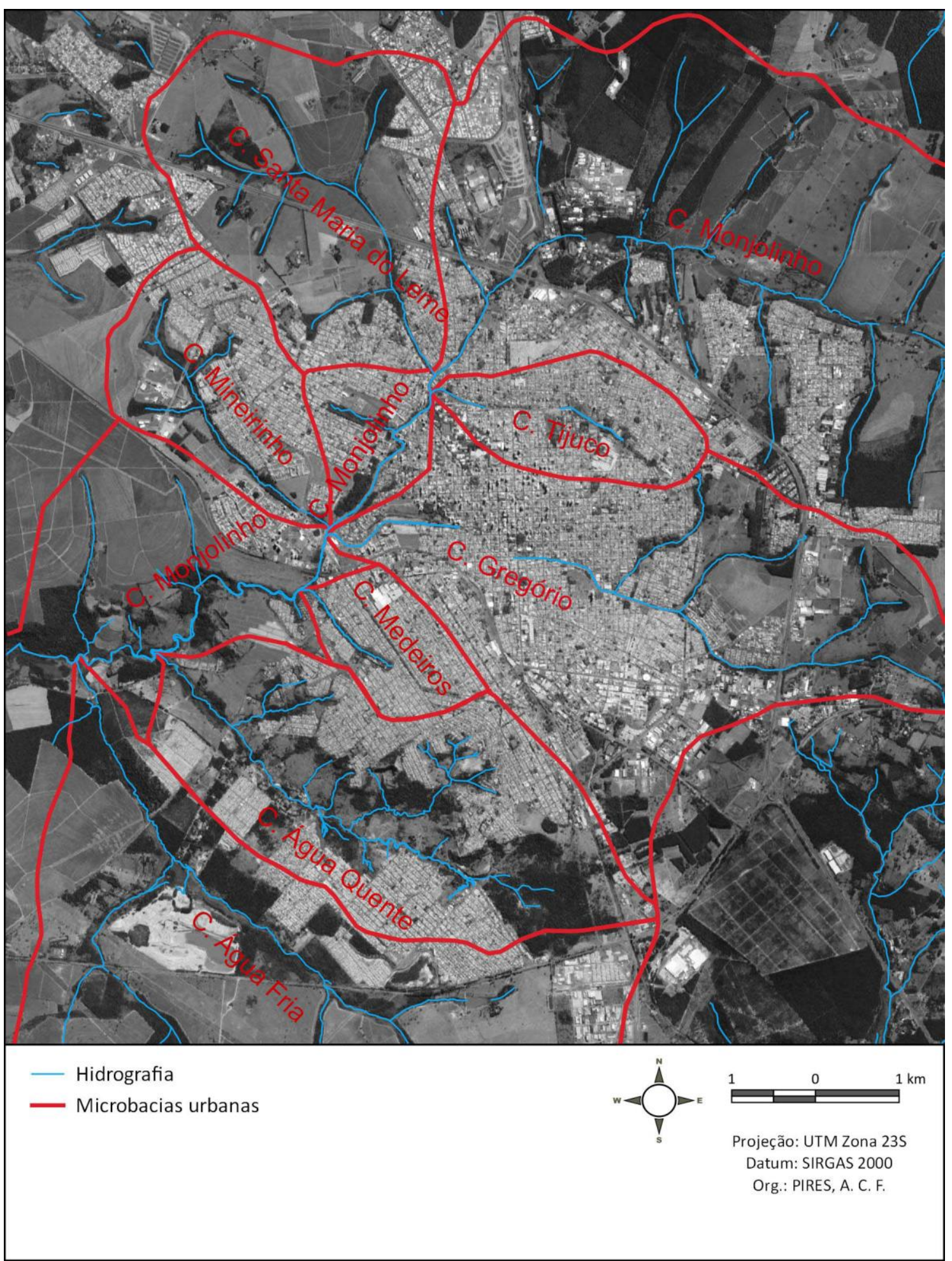

Mapa 2: Imagem de São Carlos, Hidrografia, Microbacias Hidrográficas

Fonte: Elaborado pela autora com base em Google Satellite, 2019 e PMSC, 2019.

O mapa 2 mostra a urbanização em relação às microbacias hidrográficas consideradas

neste estudo. Destacam-se em vermelho as cumeadas, os divisores de água que reúnem os pontos mais altos destas bacias hidrográficas. 


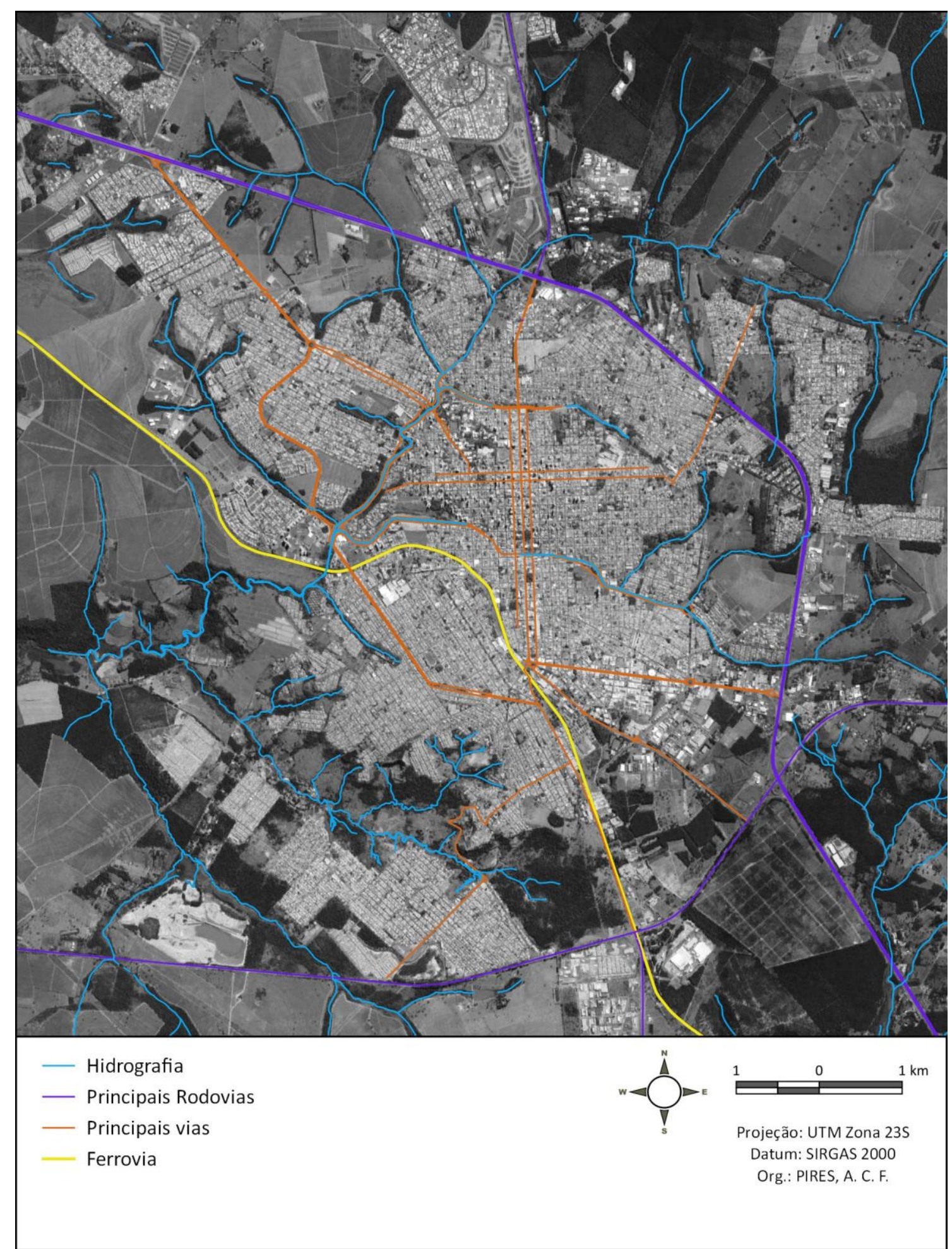

Mapa 3: Imagem de São Carlos, Hidrografia, Principais Vias, Principais Rodovias, Estradas de Ferro. Fonte: Elaborado pela autora com base em Google Satellite, 2019 e PMSC, 2019.

No mapa 3 pode-se visualizar as principais vias de ligação da cidade e o traçado da malha urbana. Notam-se diversas vias que se estendem sobre cursos d'água e as avenidas marginais a eles. 


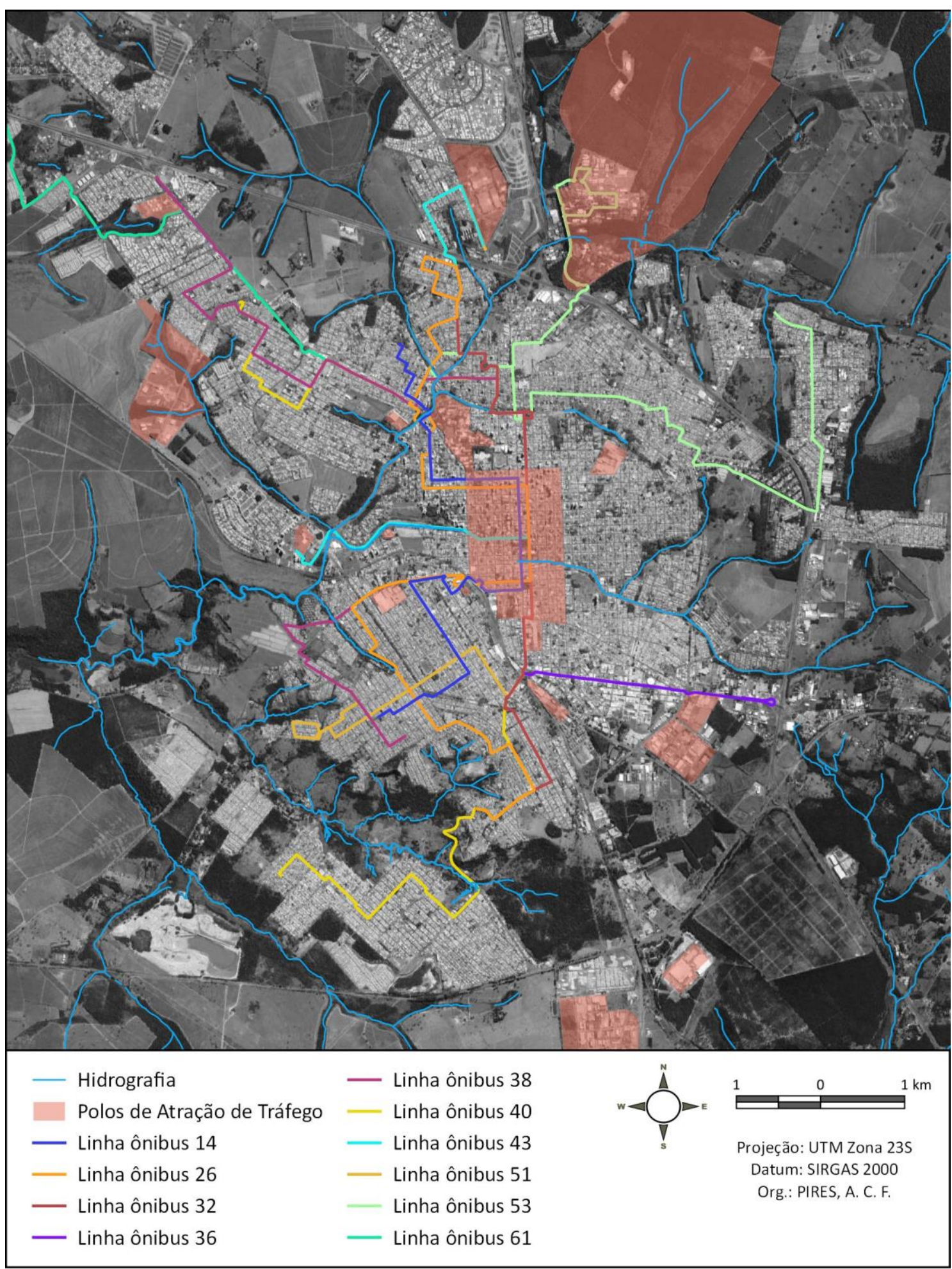

Mapa 4: Imagem de São Carlos, Hidrografia, Linhas de Ônibus, Polos de Atração de Tráfego Fonte: Elaborado pela autora com base em Google Satellite, 2019; PMSC, 2019; Suzantur,2019; SÃO CARLOS, 2009. 
O mapa 4 mostra 10 linhas de ônibus ${ }^{131}$ que ilustram o transporte coletivo na cidade, sinalizando ligações e acessos de diferentes regiões da cidade. Os polos de atração ${ }^{132}$ de tráfego representam os locais onde há um fluxo maior de pessoas e, se articulados ao SEL, podem gerar diretrizes de planejamento de transporte.

${ }^{131}$ Foram escolhidas 10 de um total de 66 linhas, apenas para demonstrar possibilidades.

132 Comércio; escolas; Mercado Municipal; Catedral; Praça XV; Biblioteca; Teatro Municipal; Indústrias; Shoppings; Parque Kartódromo; Parque Bicão; SESC; SESI; campi universitários USP, UFSCar, Unicep (Plano Cicloviário 2009). 


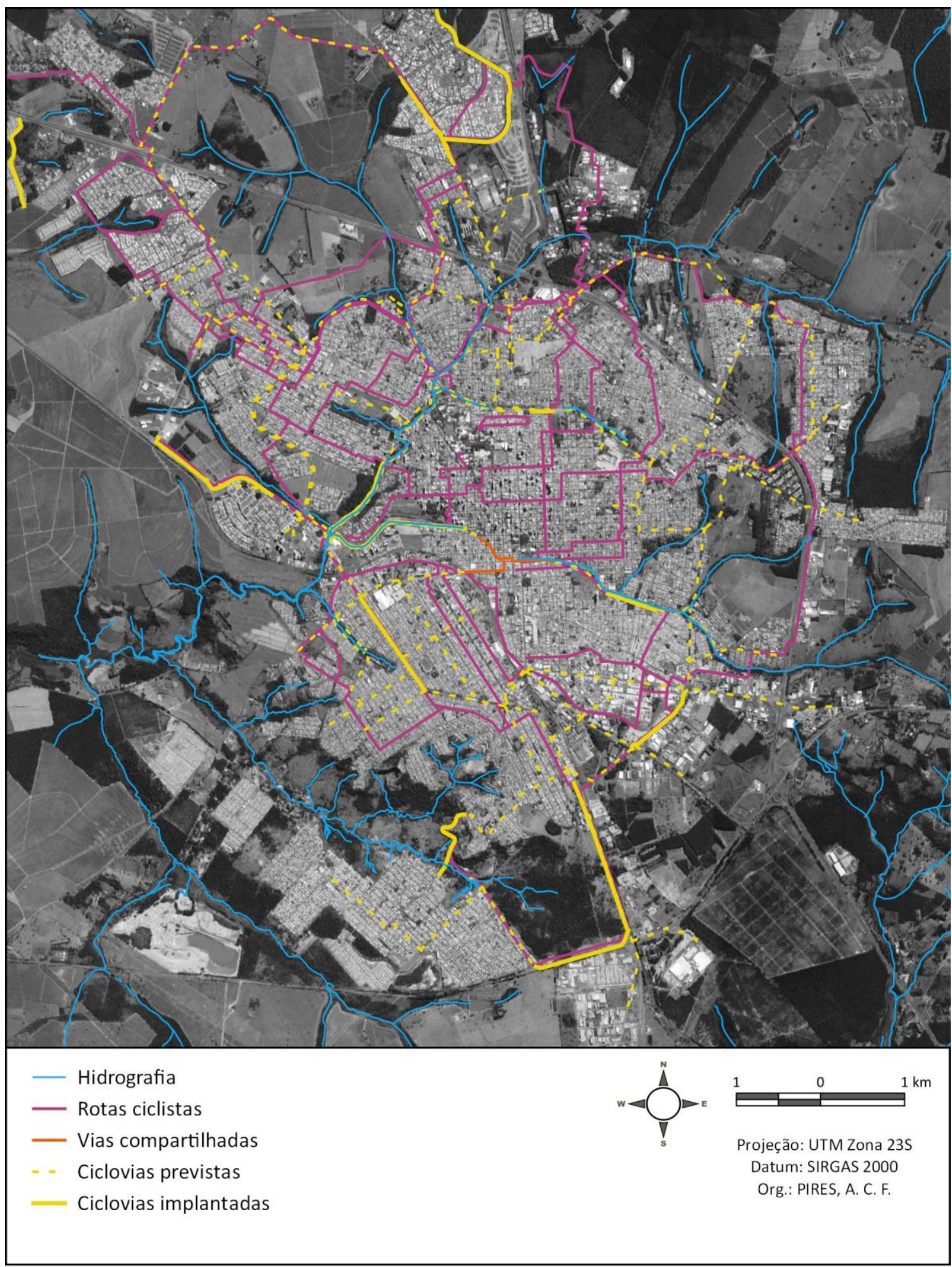

Mapa 5: Imagem de São Carlos, Hidrografia, Ciclovias Implantadas, Ciclovias Previstas, Vias Compartilhadas; Rotas Ciclistas.

Fonte: Elaborado pela autora com base em Google Satellite, 2019; PMSC, 2019; SÃO CARLOS, 2009; ONG Ciclismo São Carlos, 2019.

As ciclovias e as ciclo rotas expostas no mapa 5 indicam possíveis conexões para o SEL, sugerindo vias que podem receber tratamento especial, através de um desenho urbano que 
promova espaços agradáveis para o deslocamento, com calçadas largas, arborização e estares. Ressalta-se o fato de muitas das ciclovias localizarem-se nos fundos de vale, onde os percursos são mais planos, e se vinculadas aos parques lineares propiciariam caminhos confortáveis de se percorrer. 


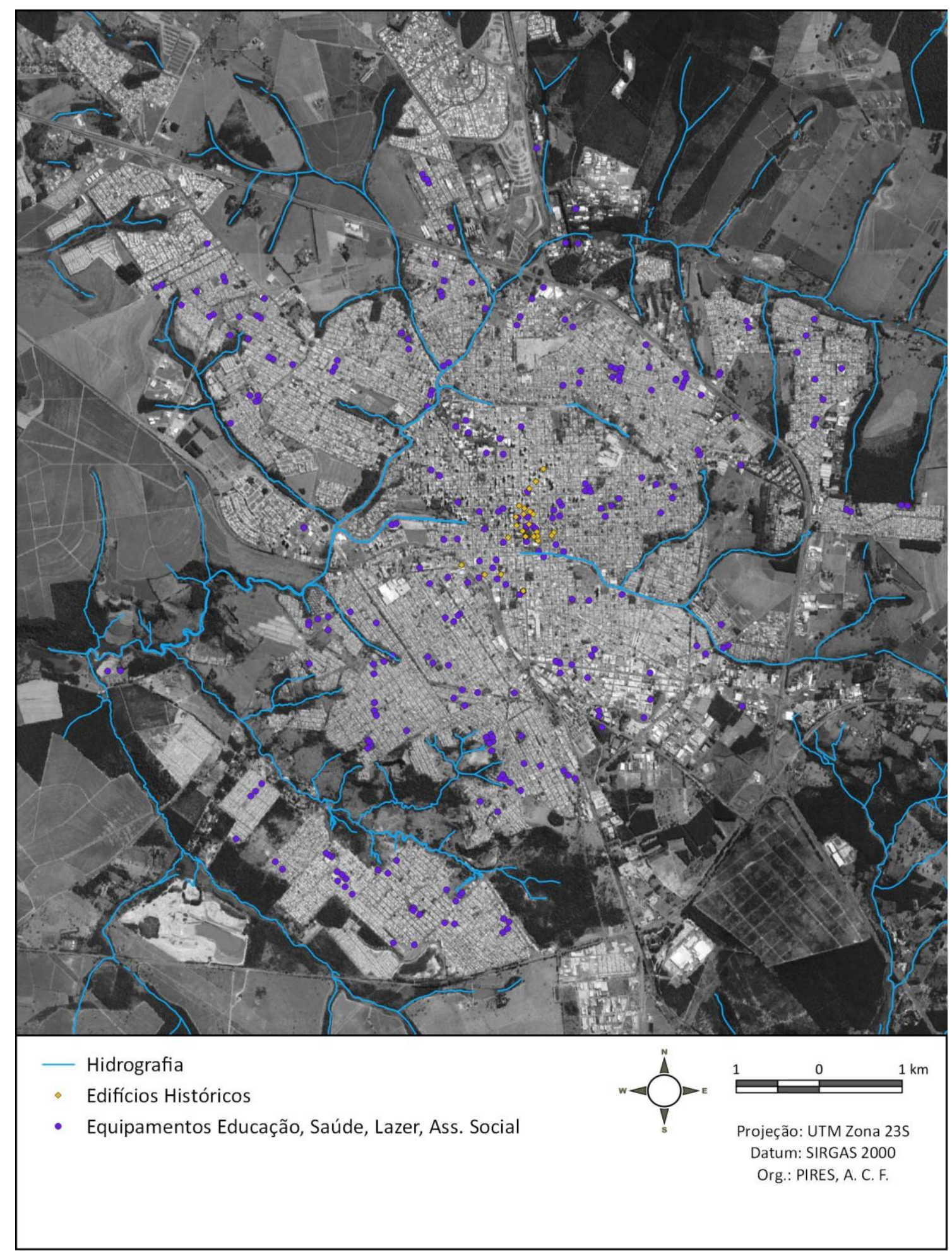

Mapa 6: Imagem de São Carlos, Hidrografia, Equipamentos de Educação, Saúde, Lazer e Assistência Social; Edifícios Históricos.

Fonte: Elaborado pela autora com base em Google Satellite, 2019; PMSC, 2019; PMSC, 2016; FPM/PMSC, 2017.

No mapa 6 identificam-se as edificações referentes aos equipamentos públicos de educação, saúde, lazer e assistência social, os edifícios históricos e os imóveis tombados em 
âmbito municipal e estadual. Uma vez articuladas ao SEL por meio de políticas públicas, estas instituições proporcionariam novos usos aos espaços livres, a exemplo de diretrizes curriculares escolares, indicando aulas nos parques e nas praças que possibilitariam novas formas de aprendizados aos alunos, ao mesmo tempo promovendo o uso, o pertencimento e o cuidado com o espaço público. 


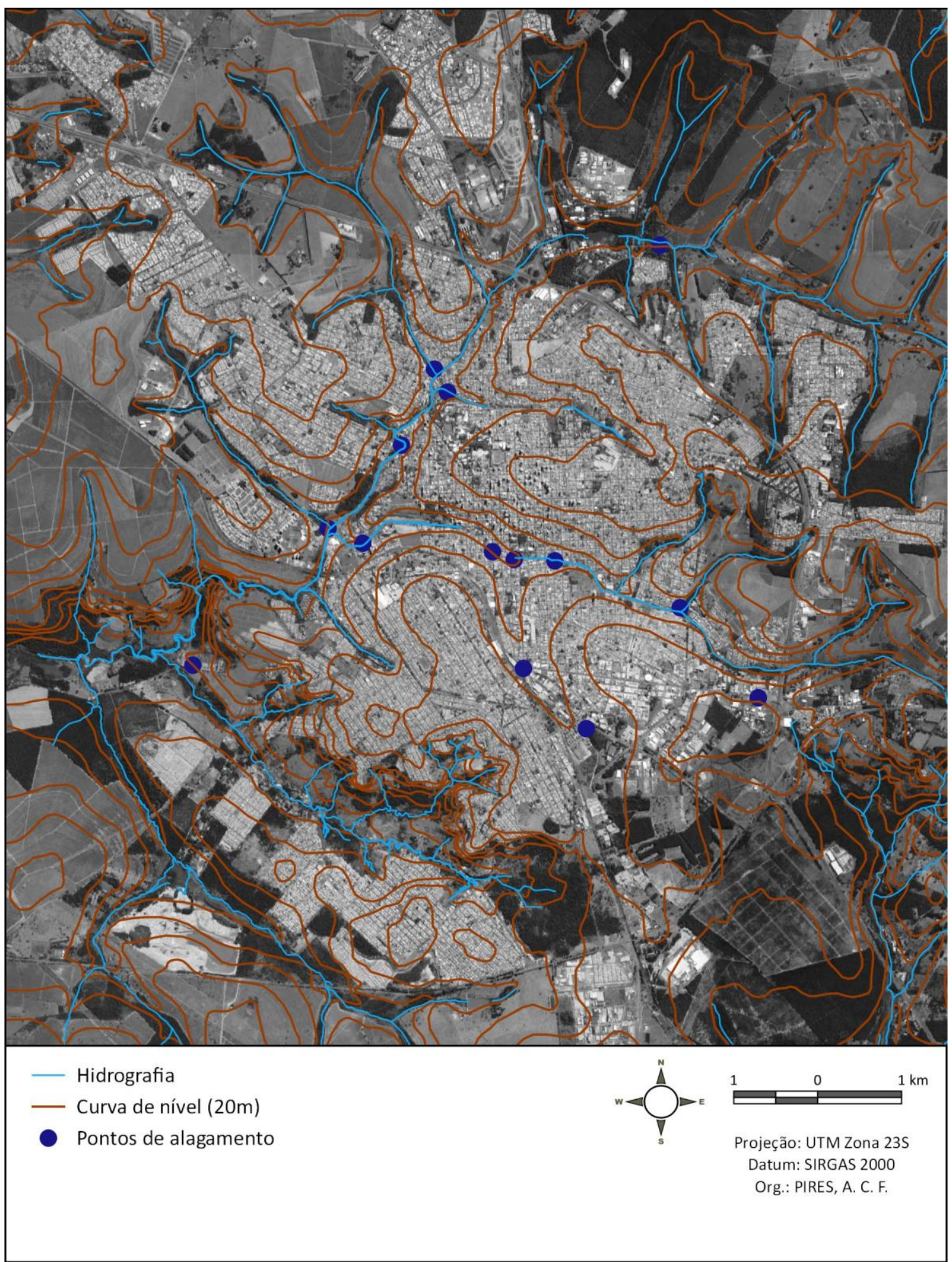

Mapa 7: Imagem de São Carlos, Hidrografia, Pontos de Alagamentos, Curvas de Nível.

Fonte: Elaborado pela autora com base em Google Satellite, 2019; PMSC, 2019; SÃO CARLOS/SHS, 2011.

O mapa 7 mostra os pontos de alagamentos em relação ao relevo. Este mapa, sobreposto ao mapa de áreas públicas (Sistema de Recreio), contribui para o estudo de localização de retenções de água em períodos chuvosos. 


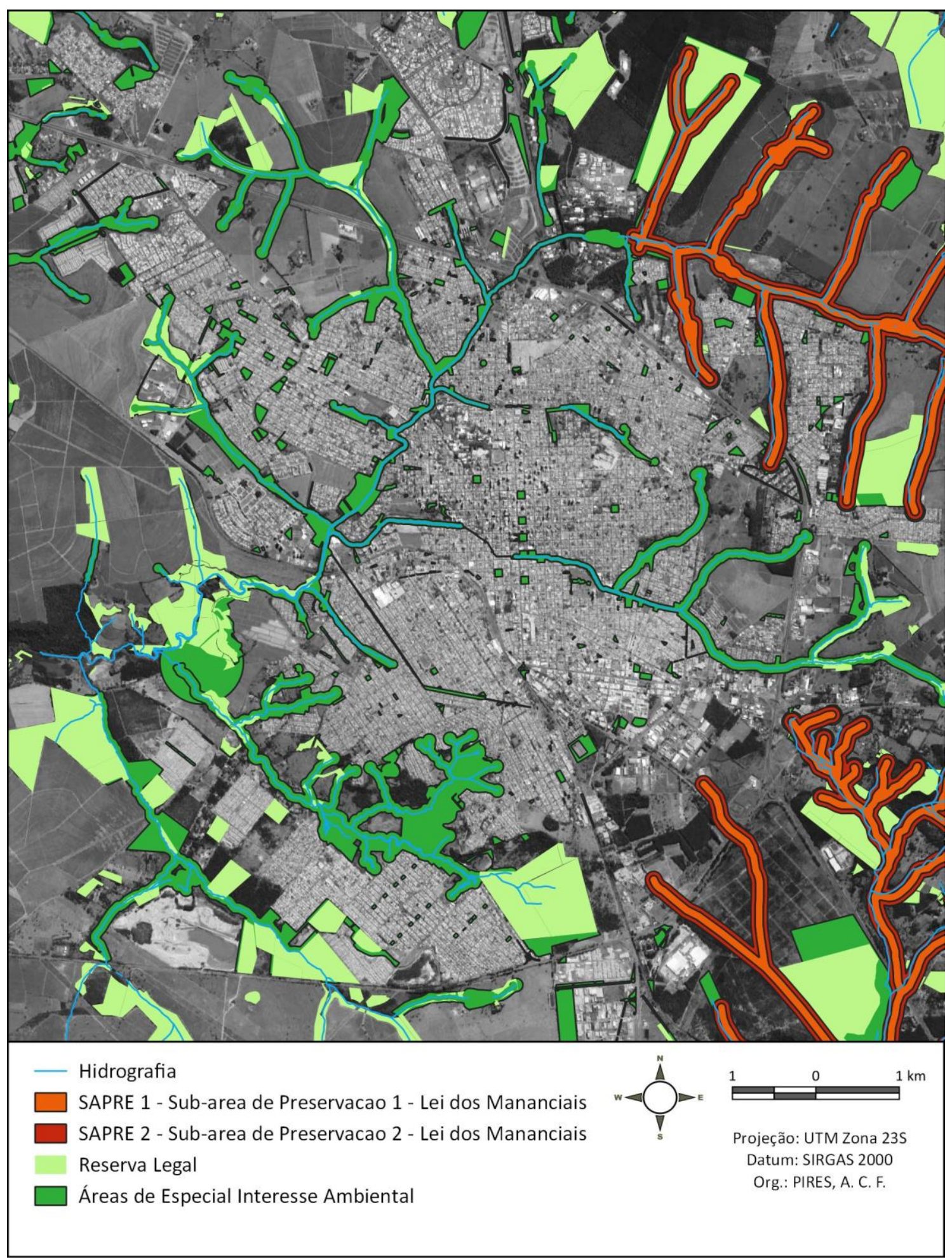

Mapa 8: Imagem de São Carlos, Hidrografia, Áreas de Especial Interesse Ambiental, Subárea de Preservação 1 (SAPRE 1) e Subárea de Preservação 2 (SAPRE 2), Reserva Legal.

Fonte: Elaborado pela autora com base em Google Satellite, 2019; PMSC, 2019; SÃO CARLOS, 2016; SÃO CARLOS, 2006; BRASIL, 2018. 
O mapa 8 mostra as Áreas de Especial Interesse Ambiental (AIA), que contemplam as áreas públicas de Sistema de Lazer, as APPs públicas e privadas, os maciços de vegetação nativa, as praças, alguns parques existentes, canteiros centrais de avenidas e rotatórias. Incluem-se ainda as Faixas Verdes Complementares junto aos corpos d'água das Zonas 6 e 7 demarcadas no Plano Diretor (2016) e as SAPREs 1 e 2 em sua totalidade.

As Reservas Legais ${ }^{133}$ são áreas vegetadas privadas com potencial para participar do SEL que não se restringem ao urbano, adentrando também os espaços periurbanos e rurais, cogitando-se um cinturão verde. Elas também exercem funções ambientais importantes e, se analisadas sistemicamente, tem sua participação ampliada na constituição de um território municipal mais sustentável. Para estas áreas e para as áreas de propriedade particular inseridas nas AIA seriam indicadas diretrizes especiais de uso e ocupação do solo, da mesma forma como foram criadas as SAPREs, de modo a garantir a manutenção destas funções ambientais. Outra opção seria incentivar os proprietários a manter ou recuperar a vegetação por meio do pagamento por serviços ambientais, uma prática que vem sendo adotada em países da Europa e que começa a ser desenvolvida no Brasil ${ }^{134}$ a partir de incentivos fiscais.

Esta cartografia foi essencial na constituição do SEL, seja por apresentar uma rede de espaços que promovem conectividade e fruição, representadas especialmente pelos cursos d’água; seja por apresentar as áreas que demandam tratamento diferenciado por cumprirem diversas funções ambientais, ou ainda, por apresentar as áreas que contribuem para drenagem de água pluvial e melhoria do microclima urbano.

\footnotetext{
133 “Reserva Legal: área localizada no interior de uma propriedade ou posse rural, delimitada nos termos do art. 12, com a função de assegurar o uso econômico de modo sustentável dos recursos naturais do imóvel rural, auxiliar a conservação e a reabilitação dos processos ecológicos e promover a conservação da biodiversidade, bem como o abrigo e a proteção de fauna silvestre e da flora nativa" (BRASIL, 2012, art. 3ㅇ).

${ }^{134}$ O Plano Diretor Estratégico de São Paulo (lei no 16.050/2014) prevê esse instrumento.
} 


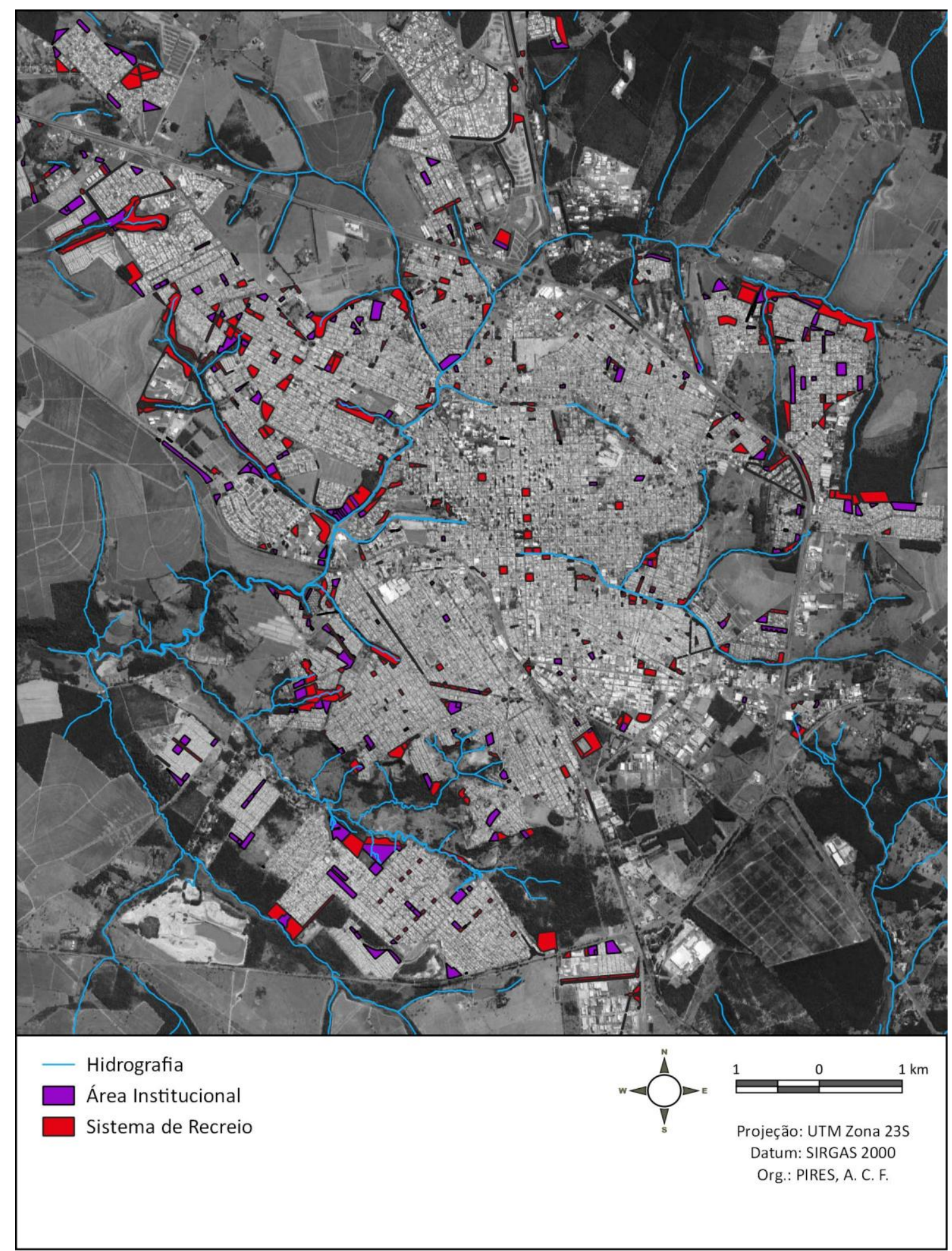

Mapa 9: Imagem de São Carlos, Hidrografia, Sistema de Recreio, Áreas Institucionais.

Fonte: Elaborado pela autora com base em Google Satellite, 2019; PMSC, 2019; PMSC, 2016. 
No mapa 9 visualizam-se o Sistema de Recreio e as Áreas Institucionais, que neste trabalho representam as áreas públicas disponíveis ${ }^{135}$. Ao analisar o mapa de Sistema de Recreio, observam-se praças, parques, canteiros centrais de avenidas, rotatórias, fragmentos de vegetação, APPs. Integrados ao SEL, estes espaços revelam locais nos quais é permitido o uso público e, portanto, poderiam ser qualificados através de um projeto que concilie o uso destes espaços e a proteção ambiental. O mapa traz também as Áreas Institucionais que, embora destinadas à edificação de equipamentos públicos, no processo de planejamento podem ser articuladas aos espaços livres do Sistema, promovendo-se usos complementares.

${ }^{135}$ A Prefeitura também estabelece uma outra cartografia denominada Áreas Públicas (2018), que além do sistema de recreio e das áreas institucionais, inclui faixas de proteção (APPs), bens dominicais, patrimônio indisponível, sistema viário, áreas concedidas. Porém, obteve-se acesso apenas aos arquivos do Sistema de Recreio e das Áreas Institucionais em formato compatível com o utilizado pelo software Qgis. 


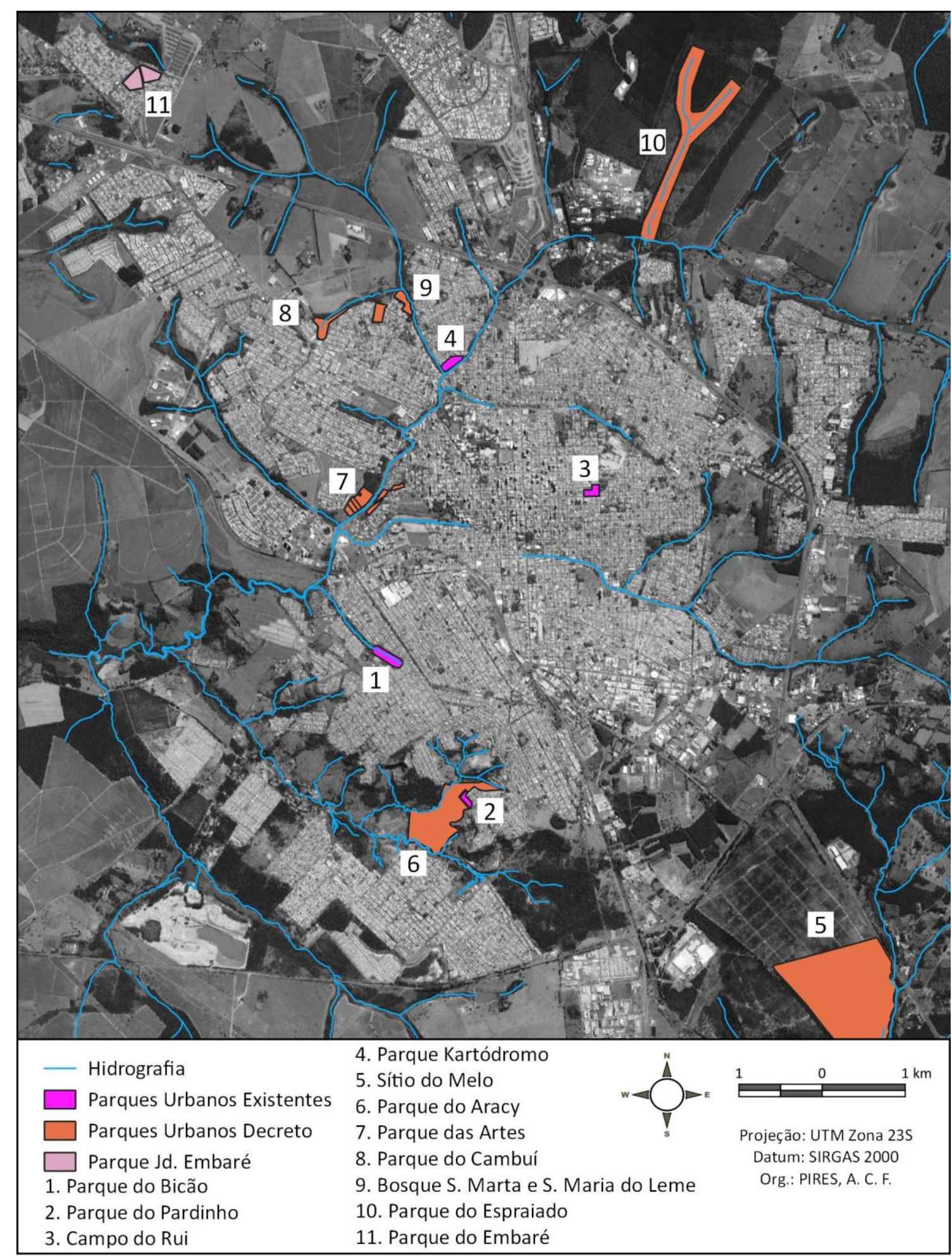

Mapa 10: Imagem de São Carlos, Hidrografia, Parques Existentes, Parques do Decreto, Parque adicionado (Jd. Embaré).

Fonte: Elaborado pela autora com base em Google Satellite, 2019; PMSC, 2019; PMSC, 2016; SÃO CARLOS, 2017; SÃO CARLOS, 2018. 
O mapa 10 apresenta os parques existentes na cidade - Parque Veraldo Sbampato, conhecido como Parque do Bicão; Parque do Pardinho; Campo do Rui; Parque do Kartódromo -; os Sete Parques Urbanos referentes ao decreto nำ170/2017 - Sítio do Melo, Parque do Aracy, Parques da Artes (duas áreas), Parque do Cambuí, Bosque Santa Marta e Santa Maria do Leme, Parque do Espraiado -; e o Parque do Jardim Embaré, adicionado pelo decreto no6/2019.

A estratégia em tela opera cartografias complexas, resultante da sobreposição e análise dos mapas, que relacionam presenças, conflitos, relações, disposições legais, e envolvem os conceitos do campo disciplinar da Arquitetura da Paisagem para guiar a leitura dos espaços livres e possibilitar a compreensão da realidade. Analisando separadamente cada um desses mapas, não seria possível abranger a totalidade dos espaços livres disponíveis na cidade, bem como as múltiplas questões envolvidas na construção desta paisagem. Ainda assim, há perspectivas de adição de outros mapas ou camadas nesta ação de planejamento, de modo a revelar outras possibilidades para o Sistema de Espaços Livres.

Sobre a finalidade da cartografia na análise de aspectos ambientais, o geógrafo Marcello Martinelli (2011) explica que a representação de um aspecto físico isolado pode manipular a realidade, assim

Diante desta realidade, a cartografia não poderá ter, como tradicionalmente se considera, uma função meramente ilustrativa. Na pesquisa, ela deve constituir um meio lógico capaz de revelar, sem ambiguidades, o conteúdo embutido na informação mobilizada e, portanto, dirigir o discurso do trabalho científico de forma abrangente, esclarecedora e crítica, socializando desmistificando o mapa, enaltecendo assim, a finalidade social da ciência cartográfica (MARTINELLI, 2011, p. 63).

\section{A construção do Sistema de Espaços Livres}

A cartografia do Sistema de Espaços Livres, nesta pesquisa, representa uma síntese das análises e leituras mostradas nos mapas anteriores, que ultrapassa a mera exposição de dados sobre aspectos físicos da paisagem. A princípio os condicionantes físicos são determinantes para o estabelecimento do SEL, posto que, historicamente, o desenvolvimento urbano de São Carlos construiu o conflito com o ambiente natural.

A partir da análise da sobreposição dos mapas, verificou-se que o Mapa 8 - Imagem de São Carlos, Hidrografia, Áreas de Especial Interesse Ambiental (AIA); Subárea de 
Preservação 1 e Subárea de Preservação 2; Reserva Legal - abrange praticamente a totalidade dos espaços livres levantados ${ }^{136}$, desta forma, constitui o ponto de partida para proposição do SEL. Ademais, esta cartografia está intrinsicamente implicada com as funções ambientais ao revelar áreas de incontestável importância para o equilíbrio do meio físico, visando sua conservação e o uso sustentável dos recursos naturais; e com a função infraestrutural associada a drenagem. No sentido mencionado por McHarg (2000) no planejamento ecológico da paisagem, os valores ambientais são considerados como valores sociais e a aptidão do lugar indica formas de uso compatíveis com a proteção do ambiente natural e da população.

A expectativa desse trabalho não é atuar a partir de uma concepção preservacionista de natureza, isolada e intocada. Ao contrário, considera-se a interligação e interdependência dos ecossistemas, almeja-se o contato e a explicitação dos processos naturais envolvidos, conforme a visão de Hough (1984), como modo de promover o pertencimento ao lugar e o cuidado destes espaços. Reforça-se essa escolha com a diretriz do Plano Diretor (2016, Art. 73), em que uma das finalidades das Áreas de Especial Interesse Ambiental é a criação de Parques Lineares e Unidades de Conservação.

A cartografia da hidrografia da cidade reflete sua relevância diante a minimização do conflito com a urbanidade já mencionado, mas não apenas por esse motivo: visualiza-se a estruturação do Sistema, inerente a fruição proporcionada pelos corpos d'água, potencial aproveitado para a conexão entre os diferentes espaços onde sua proximidade pode significar benefícios mentais e físicos.

A rede hidrográfica é indissociável da concepção de bacia hidrográfica, assim qualquer ação no território de uma bacia reflete-se na qualidade de suas águas e, portanto, guiará a etapa posterior de se planejar com as potencialidades da paisagem. A boa qualidade das águas propicia esse encontro e, em termos metodológicos, a próxima etapa (apresentada no final deste Capítulo) é aquela que vai à escala do fenômeno, percorrendo a bacia.

Ainda nesta sobreposição referente à primeira etapa, somaram-se ao Mapa 8, o Mapa 9 - Imagem de São Carlos, Hidrografia, Sistema de Recreio, Áreas Institucionais; e o Mapa 10

\footnotetext{
${ }^{136}$ Existem espaços que poderiam ser acrescentados, mas que exigiriam a elaboração de outros critérios não abordados nesta dissertação: grandes áreas sem edificação no interior dos campi universitários (USP, UFSCar, UNICEP) e Clubes; áreas de lazer de condomínios fechados; grandes terrenos privados desocupados; áreas de agricultura; área de extração de rochas desativada.
} 
- Imagem de São Carlos, Hidrografia, Parques do Decreto, Parque adicionado (Embaré),

Parques Existentes, que retratam as áreas públicas ou legalmente declaradas como parques.

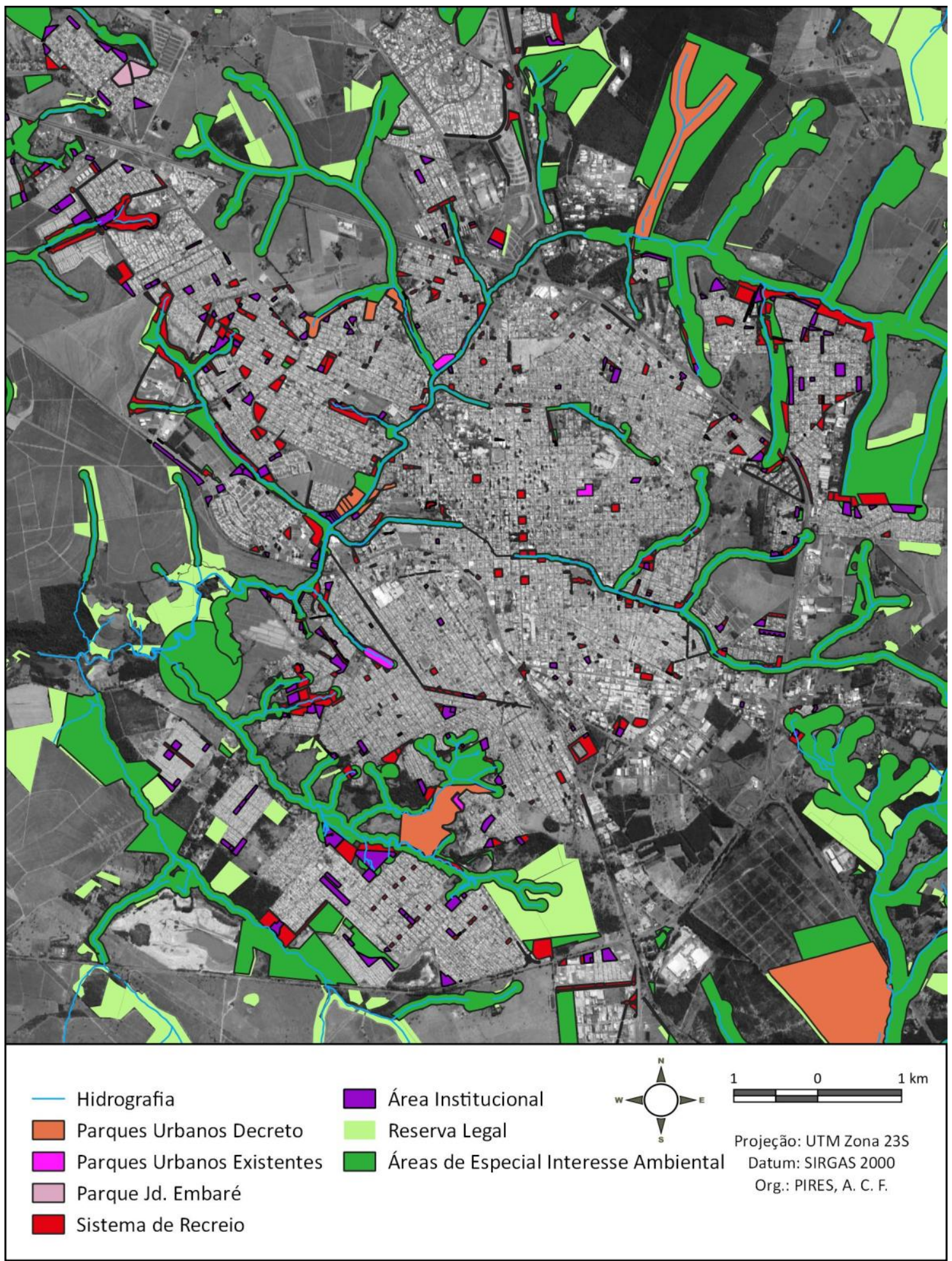

Mapa 11: Síntese para a proposição do Sistema de Espaços Livres.

Fonte: Elaborado pela autora com base em Google Satellite, 2019; PMSC, 2019; PMSC, 2016; SÃO CARLOS, 2006; SÃO CARLOS, 2016; SÃO CARLOS, 2017; SÃO CARLOS, 2019; BRASIL, 2018. 
A cartografia acima (Mapa 11) apresenta a síntese dos potenciais espaços para compor o SEL, isto é, a partir da sobreposição dos mapas escolhidos, que representam a totalidade dos espaços livres disponíveis na cidade. No entanto, é necessário aprimorar esta cartografia, pois muitas camadas são coincidentes, além disso, percebe-se que algumas áreas são edificadas, principalmente na camada referente à AIA, conforme constatou-se na análise do Plano Diretor Estratégico (2016).

Também é necessário classificar estes espaços por meio de categorias, agrupar elementos semelhantes para organizar o Sistema de Espaços Livres e, deste modo, facilitar a elaboração de políticas públicas e leis, assim como a destinação de recursos para a implantação dos parques.

\subsection{Levantamento de Categorias para um Sistema de Espaços Livres}

O levantamento sobre as potenciais categorias para um Sistema de Espaços Livres ocorreu através de revisão bibliográfica, com foco em autores relevantes no campo da Arquitetura da Paisagem. A fim de construir um referencial teórico que auxiliasse na escolha de categorias específicas para um SEL em São Carlos e tendo em vista a complexidade da paisagem, buscou-se estabelecer relações, aproximações e afastamentos dos pontos de vista destes autores, apresentados cronologicamente, em âmbito internacional e depois nacional.

Na literatura sobre Sistema de Espaços Livres, o termo "categoria" se refere a uma série de atributos que o espaço livre assume e que permite a sua classificação num dado sistema. De acordo com Whately et al. (2008) em seus estudos sobre os parques urbanos da cidade de São Paulo, a classificação em categorias advém da combinação de características específicas de cada sítio e considera sua dimensão, a presença de recursos naturais e o grau de integridade dos mesmos, a existência de equipamentos ou monumentos históricos, e os principais usos, com ênfase no contexto em que está inserido. Com base nas categorias é possível propor instrumentos de gestão, como planos de manejo e programas adequados para cada conjunto de espaços, atendendo de forma mais assertiva suas particularidades e necessidades, visando a constituição do SEL (WHATELY et al., 2008). 
O pioneiro na elaboração de categorias para os espaços livres de uma cidade foi o engenheiro florestal francês Forestier (apresentado no Capítulo 1), que em 1906 organizou o conhecimento sobre o Sistema de Parques no livro Grandes Villes et Systèmes de Parcs. Numa época em que o centro de Paris estava congestionado e a cidade se expandia rapidamente em direção ao subúrbios, Forestier distinguiu diferentes espaços que constituiriam um sistema, referenciando o pioneiro da Arquitetura da Paisagem, Frederick Law Olmsted, que havia iniciado essa hierarquização. Forestier defendia que a reserva de áreas verdes nas cidades se relacionava com a qualidade de vida, assim procurou distribuir os espaços livres de forma que fossem acessíveis para toda a população. Estes espaços, classificados em relação a hierarquias de escalas, de conservação e de uso, seriam articulados formando o Sistema de Parques. Resgata-se do primeiro capítulo os elementos que compõem esse Sistema (Quadro 1):

Quadro 1: Categorias do Sistema de Parques de Forestier.

\begin{tabular}{|c|c|}
\hline CATEGORIAS & CARACTERÍSTICAS/ FUNÇÕES \\
\hline $\begin{array}{l}\text { Grandes reservas e as paisagens } \\
\text { protegidas }\end{array}$ & $\begin{array}{l}\text { De superfície variável, localizadas nas adjacências do perímetro urbano } \\
\text { ou um pouco mais distantes, possuíam vegetação em seu estado mais } \\
\text { natural e que, dependendo das circunstâncias e de sua configuração, } \\
\text { podiam ser preservadas. }\end{array}$ \\
\hline Parques suburbanos & $\begin{array}{l}\text { Regularmente distribuídos pela cidade, demandavam manutenção e } \\
\text { teriam tratamento adequado para atender as necessidades da } \\
\text { população. Eram considerados refúgios ao alcance dos habitantes. }\end{array}$ \\
\hline Grandes parques urbanos & $\begin{array}{l}\text { Possuíam tratamento paisagístico, grandes gramados, áreas } \\
\text { sombreadas, locais para recreação e repouso. Facilmente acessados } \\
\text { por meio de caminhadas pela cidade. Contribuíam para o } \\
\text { embelezamento e higiene da cidade. }\end{array}$ \\
\hline $\begin{array}{l}\text { Pequenos parques e os jardins de } \\
\text { bairro }\end{array}$ & $\begin{array}{l}\text { Abrigariam locais para jogos e exercícios, devendo ser bem } \\
\text { distribuídos, de forma que cada família não tivesse que se deslocar } \\
\text { mais que } 1000 \text { metros para acessá-los. }\end{array}$ \\
\hline Terrenos de recreação & $\begin{array}{l}\text { Em grande quantidade, constituíam pequenos campos de recreação } \\
\text { com áreas separadas para diversão das crianças em diferentes idades } \\
\text { e áreas de ginastica para adultos. }\end{array}$ \\
\hline Jardins de infância & Associados às escolas, seriam utilizados no processo de aprendizado. \\
\hline Avenue-promenades & $\begin{array}{l}\text { Largas avenidas arborizadas projetadas para deslocamentos e } \\
\text { permanências agradáveis, permitiriam valorizar os pontos de vista, as } \\
\text { margens dos rios e as paisagens interessantes e pitorescas. } \\
\text { Promoveriam a articulação do sistema, conectariam todos os espaços } \\
\text { verdejados e, estes às saídas para o campo. }\end{array}$ \\
\hline
\end{tabular}

Fonte: Elaborado pela autora com base em FORESTIER, 1997 p. 59-69.

Em 1944, quase findada a Segunda Guerra Mundial e na expectativa de reconstrução das cidades e suas paisagens sobre novas bases, Patrick Abercrombie elaborou o Plano para a Grande Londres (Greater London Plan), que incluía um Sistema de Espaços Livres. Conforme 
mostrado no Capítulo 1, a região enfrentava problemas devido a adensamento populacional e construtivo e, com o bombardeamento, principalmente sobre as concentrações industriais, reforçou-se a necessidade de um planejamento que promovesse a dispersão destas áreas e das habitações.

Abercrombie alertou para a necessidade de se preservar qualquer espaço verde existente no interior da malha urbana para, a longo prazo, promover a recuperação de tais áreas e possibilitar sua utilização pela população. O Plano de Abercrombie (1945) contava com um Sistema de Espaços Livres, que aproveitava oportunidades da topografia natural para propor diferentes tipos de espaços, visando atender usos diversificados de acordo com as demandas de seus usuários. Estes espaços seriam de tamanhos e qualificações variadas e abrangeriam todas as composições fundiárias (Quadro 2). 
Quadro 2: Categorias do Sistema de Espaços Livres proposto por Abercrombie.

\begin{tabular}{|c|c|}
\hline CATEGORIAS & CARACTERÍSTICAS/ FUNÇÕES \\
\hline Parques infantis & Para crianças até 10 anos de idade. \\
\hline Praça da cidade, jardins de descanso & Localizados na área urbana consolidada. \\
\hline Playgrounds e espaços livres escolares & Poderiam estar combinados com os parques urbanos. \\
\hline \multicolumn{2}{|l|}{ Parques urbanos } \\
\hline $\begin{array}{l}\text { Grandes campos de jogos para adultos e } \\
\text { crianças em idade escolar }\end{array}$ & Preferencialmente na escala local. \\
\hline Centros de recreação e esportes & $\begin{array}{l}\text { Grandes áreas destinadas aos jogos ou à contemplação da } \\
\text { paisagem, oferecidos de acordo com as necessidades da } \\
\text { comunidade. }\end{array}$ \\
\hline $\begin{array}{l}\text { Parques lineares/ Parkways radiais e } \\
\text { conectoras }\end{array}$ & $\begin{array}{l}\text { Elos de ligação do sistema, como faixas alongadas de espaço } \\
\text { livre de largura variável, relacionadas aos cinturões menores; } \\
\text { caminhos ribeirinhos; trilhas (footpaths), que geralmente } \\
\text { consistiam em direito de passagem sobre terras agrícolas; } \\
\text { Compreendem também estradas rurais; ciclovias; estradas com } \\
\text { tratamento paisagístico e com tráfego destinado ao deleite do } \\
\text { caminho e com locais adequados à parada; estradas arteriais } \\
\text { expressas de trafego motorizado, que não seriam consideradas } \\
\text { parte do Sistema de Parques, mas dariam acesso aos espaços } \\
\text { livres. }\end{array}$ \\
\hline Espaços abertos interpenetrados & $\begin{array}{l}\text { Poderiam se sobrepor a outros espaços, conectando-os para } \\
\text { formar o sistema. }\end{array}$ \\
\hline Cinturões verdes pequenos & Definir os limites e a expansão das comunidades. \\
\hline Áreas comuns e áreas de várzea & $\begin{array}{l}\text { Várzeas e outras terras baixas seriam regiões sujeitas a } \\
\text { inundações, portanto não seriam adequadas para a construção. }\end{array}$ \\
\hline Espaços ao redor do rio Tâmisa e outros rios & $\begin{array}{l}\text { O Tâmisa era considerado de grande valor recreacional para os } \\
\text { londrinos, pois fornecia variados tipos de atividades para } \\
\text { diferentes grupos da população. Considerava os benefícios } \\
\text { propiciados pelos cursos d'água e seus vales. Objetivo seria } \\
\text { aumentar as áreas abertas ao uso público, recuperar áreas } \\
\text { industriais degradas e integrá-las ao sistema. }\end{array}$ \\
\hline $\begin{array}{l}\text { Cinturão Verde Metropolitano, florestas, } \\
\text { colinas, parques campestres }\end{array}$ & Definir os limites à expansão da região metropolitana. \\
\hline Áreas de grande valor cênico & $\begin{array}{l}\text { Áreas com características notáveis, por exemplo, algumas } \\
\text { colinas, picos, escarpas, encostas, florestas, várzeas. Era } \\
\text { desejável que essas terras mudassem para a posse pública } \\
\text { absoluta para terem proteção mais eficiente. }\end{array}$ \\
\hline Área rural & $\begin{array}{l}\text { Terrenos que sofriam influência urbana direta - terras do } \\
\text { cinturão verde (green belt farmland); campo agrícola normal; e } \\
\text { terras distantes dos efeitos urbanos. Seriam acessíveis para } \\
\text { recreação somente por trilhas, caminhos verdes e estradas } \\
\text { rurais a partir das áreas urbanas e pelas faixas de espaço livre. }\end{array}$ \\
\hline
\end{tabular}

Fonte: Elaborado pela autora com base em ABERCROMBIE, 1945, p. 103.

Richard Forman, em seu estudo sobre a ecologia da paisagem, identificou os "mosaicos de terra", elementos espaciais que formavam o ambiente e tinham origem nos processos naturais, nos acidentes naturais e naqueles provocados pelo homem. Estes elementos estavam dispostos em um arranjo padrão encontrado em diferentes escalas 
espaciais e contextos e se relacionavam hierarquicamente. O Quadro 3 a seguir retoma os três elementos espaciais sugeridos por Forman (1995).

Quadro 3: Elementos espaciais dos mosaicos de terra proposto por Forman.

\begin{tabular}{|l|l|}
\hline CATEGORIAS & CARACTERÍSTICAS/ FUNÇÕES \\
\hline Matriz & Extensa área continua e homogênea, apresenta menor grau de fragmentação. \\
\hline Corredor & $\begin{array}{l}\text { Faixa que difere dos seus arredores, elemento linear, pode ser largo ou estreito, } \\
\text { sinuoso ou retilíneo. Permite a interligação ou fluxo ecossistêmico. Exemplos: } \\
\text { corredores de vegetação, cordilheiras, vales fluviais, litorais, faixas de subúrbio. }\end{array}$ \\
\hline Fragmento ou mancha & $\begin{array}{l}\text { Área relativamente homogênea e diferente do entorno, que poderia ser de } \\
\text { diferentes dimensões e formatos, como no formato alongado ou arredondado. } \\
\text { Exemplos: campos de agricultura, florestas. }\end{array}$ \\
\hline
\end{tabular}

Fonte: Elaborado pela autora com base em FORMAN, 1995, p. 3-7.

A grande questão acerca desse autor é que seu trabalho tem como foco fundamental a paisagem e sua ecologia, a utilização das cidades e seus espaços, de maneira que a transposição para o ambiente urbano é algo que exige grande mediação. Por exemplo, o que não deve ser ocupado segundo suas classificações, neste trabalho acredita-se que poderia e deveria ser ocupado, dado que a presença da vida social gera visibilidade dos processos naturais. Não se pode esquecer da dimensão pedagógica que os projetos e suas paisagens devem ter na vida da população, conforme apontado por Olmsted (SCHENK, 2008).

No contexto brasileiro atual, a arquiteta da paisagem Miranda Magnoli em seu artigo sobre Espaços Livres (2006a) divulgou uma classificação com base em normas californianas ${ }^{137}$, que organiza funções de forma bem compartimentada. Magnoli (2006a) identificou a sobreposição de funções e uma grande variação referente a escala e formas que poderiam coexistir no mesmo espaço em tempos diferentes (Figura 46).

\footnotetext{
${ }^{137}$ Magnoli (2006a) explicou que tomou conhecimento desta classificação através de Fernando Chacel, em um curso de Paisagismo na Associação Brasileira de Arquitetos Paisagistas (ABAP).
} 
1.1 - Florestas explorativas

1.2 - Terras agrícolas

1.2.1 - com alto grau de fertilidade

1.2 .2 - com culturas especiais

1.2 .3 - de culturas florais

1.3 - Zonas de extração de minerais

1.3.1 - minerais raros

1.3.2 - minerais utilizados localmente (saibros, pedras, etc.)

1.4 - Terrenos para pasto

1.5 - Terrenos importantes para recursos hídricos

1.5.1 - zonas de alimentação de lençóis subterrâneos

1.5.2 - lagos de vertentes

1.5.3 - barragens para a adução de água

1.5.4 - barragens para a produção de eletricidade

1.6 - Zonas de produção de vida aquática (brejos, zonas inundáveis) para fins comerciais ou lazer

2. Espaços Livres Para Proteção de Recursos Naturais e Culturais

2.1 - Águas em todas as suas formas, brejos, pântanos servindo de habitação à forma aquática

2.2 - Bosques e florestas para reservas naturais

2.3 - Características geológicas

2.3.1 - penhascos, promontórios, rochedos excepcionais específicos

2.3.2 - zonas de deslizamento

2.3.3 - zonas de conformações ou formações especiais

2.4 - Locais de monumentos históricos ou culturais

2.4.1 - locais classificados pela história

2.4 .2 - locais parte da memória

2.4 .3 - paisagens agrárias excepcionais

\section{Espaços Livres, Sanitários e Sociais}

3.1 - Zonas de proteção das águas subterrâneas (trabalha com 1.5.1 e 2.1

3.2 - Zonas de depósito de lixo

3.3 - Zonas de regeneração de ar (conformações topográficas ou florestas)

3.4 - Zonas de lazer

3.4.1 - jardins e praças públicas de quarteirões

3.4 .2 - parques urbanos nos vários níveis

3.4.3 - parques regionais e outras áreas de reserva, etc., que podem ser utilizadas com essa fertilidade

3.5 - Zonas de deslocamento para o lazer

3.5.1 - circulação, pistas para ciclistas, equitação, etc.

3.5.2 - estradas turísticas

3.5 .3 - rios e canais navegáveis

3.6 - Zonas de pontos de vistas notáveis

3.6.1 - morros, vales, flancos e colinas, lagos capazes de propiciar prazer visual em oposição à paisagem artificial das cidades

3.6.2 - morros propiciando panorama excepcional

3.6.3 - espaços que propiciam variedade, enriquecimento e ruptura na paisagem edificada densa ou excessivamente homogênea

3.7 - Zonas para controle e guia do crescimento urbano

3.7.1 - capazes de permitir identificação das aglomerações urbanas

3.7.2 - assegurando separação entre usos do solo (incompatíveis)

\section{Espaços Livres Para Segurança Pública}

4.1 - Barragem de controle de zonas de inundação, zonas siłuadas na área de influências de barragens

4.2 - Zonas de solo instável

4.2 .1 - por deslizamento

4.2 .2 - por declives acentuados

4.2.3 - por sobrevôo de aeroportos

4.2 .4 - por riscos de incêndio

\section{Espaços Livres-Corredores}

5.1 - Linhas de alta tensão

5.2 - Canais e canalizações diversa

5.3 - Vias rodoviárias e ferroviárias

6. Espaços Livres Para extensão Urbana, Zonas Para Comércio, Indústria, Habiłação

Equipamentos Públicos, etc.

Figura 46: Funções dos Espaços Livres Urbanos de acordo com normas californianas. Fonte: MAGNOLI, 2006a, p. 180-181. 
De acordo com a autora, a especificidade funcional não é necessária para todas as atividades, sendo possível trabalhar com espaços em "branco de significados", espaços que comportariam vários usos e apropriações de acordo com as demandas da população, sem imposição a priori por parte do projeto. Nesse sentido Macedo (1995) concorda com Magnoli (2006a):

A multiplicidade de usos é muito grande e tais atividades se dão em espaços que não foram projetados para tal fim. Estes são, por muitas vezes, mais variados que os encontrados em espaços especialmente destinados a jogos e à recreação como setores de parques e praças.

As ruas podem se constituir, e se constituem na maioria dos casos, em espaços de lazer, possibilitando encontros informais, jogos e até algumas atividades de trabalho, como a lavagem e o conserto de veículos, e, como tal devem ser consideradas em todo e qualquer planejamento de áreas de lazer (MACEDO, 1995, p. 22-23).

Bartalini (1986) identificou três conjuntos de valores nos quais agrupou as funções assumidas pelas áreas verdes e os espaços livres no meio urbano: valores visuais (referenciais), relacionados à identidade visual dos lugares e às características físicas do sítio; valores recreativos, que consideram tanto os espaços convencionais (praças, parques, campos de esporte) quantos os eventuais (ruas, lotes vagos) nas diferentes escalas e demandas; valores ambientais, em referência às funções de proteção e conservação da natureza, controle microclimático etc. $O$ autor ressaltou que essas funções não se excluem e sua integração seria ideal, tendo melhor desempenho as propostas que consideram diferentes funções, especificidades do sítio, processos naturais e sociais, e valores culturais, pois assim os espaços são mais facilmente conservados e protegidos devido ao significado coletivo que adquirem.

Outra referência de classificação dos espaços livres em categorias é o Plano Diretor Estratégico de São Paulo (SÃO PAULO, 2014), que apresentou o Sistema de Áreas Protegidas, Áreas Verdes e Espaços Livres, como forma de qualificar, preservar, conservar, recuperar e ampliar as distintas tipologias de áreas e espaços que o compõe, elaborando uma estratégia que contempla definições, objetivos, diretrizes, instrumentos e recursos necessários para implantação do Sistema. De acordo com o Plano, estas áreas são consideradas de interesse público para o cumprimento de funções ecológicas, paisagísticas, produtivas, urbanísticas, de lazer e de práticas de sociabilidade. Os componentes desse Sistema foram organizados em 
três grandes conjuntos, tendo por base a situação fundiária: áreas públicas; áreas privadas; terras indígenas (Quadro 4).

Quadro 4:

Componentes do Sistema Municipal de Áreas Protegidas, Áreas Verdes e Espaços Livres de São Paulo.

\begin{tabular}{|l|l|}
\hline SITUAÇÃO & CATEGORIAS \\
\hline Áreas públicas & $\begin{array}{l}\text { a) Unidades de Conservação de Proteção Integral que compõem o Sistema Nacional de } \\
\text { Unidades de Conservação; }\end{array}$ \\
\hline & b) parques urbanos; \\
\hline c) parques lineares da rede hídrica; \\
\hline & d) outras categorias de parques a serem definidas pelo Executivo; \\
\hline & $\begin{array}{l}\text { e) espaços livres e áreas verdes de logradouros públicos, incluindo praças, vias, vielas, } \\
\text { ciclovias, escadarias; }\end{array}$ \\
\hline & $\begin{array}{l}\text { f) espaços livres e áreas verdes de instituições públicas e serviços públicos de educação, } \\
\text { saúde, cultura, lazer, abastecimento, saneamento, transporte, comunicação e } \\
\text { segurança; }\end{array}$ \\
\hline & g) espaços livres e áreas verdes originárias de parcelamento do solo; \\
\hline & h) Áreas de Preservação Permanente inseridas em imóveis de propriedade pública; \\
\hline & i) cemitérios públicos; \\
\hline áreas privadas & a) Unidades de Conservação de Uso Sustentável; \\
\hline b) Áreas de Preservação Permanente inseridas em imóveis privados; \\
\hline & $\begin{array}{l}\text { c) espaços livres e áreas verdes de instituições e serviços privados de educação, saúde, } \\
\text { cultura, lazer, abastecimento, saneamento, transporte, comunicação, segurança e } \\
\text { cemitérios; }\end{array}$ \\
\hline & $\begin{array}{l}\text { d) espaços livres e áreas verdes com vegetação nativa em estágio avançado em imóveis } \\
\text { residenciais e não residenciais isolados; }\end{array}$ \\
\hline & $\begin{array}{l}\text { e) espaços livres e áreas verdes com vegetação nativa em estágio avançado em imóveis } \\
\text { residenciais e não residenciais em condomínios; }\end{array}$ \\
\hline & f) clubes de campo; \\
\hline g) clubes esportivos sociais; \\
\hline h) cemitérios particulares; \\
\hline i) sítios, chácaras e propriedades agrícolas; \\
\hline Terras indígenas & $\begin{array}{l}\text { a) terras indígenas homologadas; } \\
\text { b) terras indígenas delimitadas pela FUNAl em análise no Ministério da Justiça. }\end{array}$ \\
\hline
\end{tabular}

Fonte: Elaborado pela autora com base em SÃO PAULO, 2014, art. 265 e 266.

\section{É fundamental destacar a relação das categorias deste Sistema com a legislação} ambiental federal, em especial a lei que institui o Sistema Nacional de Unidades de Conservação ${ }^{138}$ (Lei no 9.985/2000) e a Lei no 12.65/2012, que dispõe sobre a proteção da

138 O Sistema Nacional de Unidades de Conservação (SNUC) estabelece as unidades de conservação federais, estaduais e municipais, divididas em dois grandes grupos com características específicas: Unidades de Proteção Integral, e Unidades de Uso Sustentável, que se subdividem em outras categorias. A classificação do SNUC não se aplica a realidade e a escala dos espaços livres nesta dissertação. Embora, ao sul da área urbana de São Carlos encontra-se a Área de Proteção Ambiental Corumbataí, que integra o grupo de Unidades de Uso Sustentável, conforme o SNUC. 
vegetação, no caso as Área de Preservação Permanente, numa tentativa de conciliar as temáticas e níveis de planejamento.

Para finalizar o levantamento sobre categorias, apresenta-se o estudo realizado por Fontes (2009), que se propôs a identificar critérios e qualificar instrumentos que pudessem auxiliar na reserva de espaços livres públicos destinados a atender as demandas de lazer e drenagem urbana, considerando especificidades socioambientais locais. Para este estudo, ela analisou Ribeirão Preto-SP, uma cidade média que assim como São Carlos enfrenta a questão das enchentes. Ela elegeu uma bacia hidrográfica, a do Córrego Laureano, para leitura da área de acordo com fragilidades do relevo em função do escoamento fluvial e pluvial, com o objetivo de sugerir medidas não estruturais para os espaços livres. A região escolhida envolve toda a área urbana e de expansão, na qual a autora também avaliou o déficit de espaços públicos para lazer ao ar livre, cogitando sugerir diretrizes para o planejamento de espaços livres em novos parcelamentos ou em processos de requalificação urbana, tendo em vista a democratização do acesso a esses espaços.

Parte-se do pressuposto de que a reserva de espaços livres públicos urbanos pode favorecer a drenagem urbana, ao mesmo tempo em que pode oferecer à cidade lugares aprazíveis e compatíveis com diferentes usos, impactando positivamente no conforto do ambiente, potencializando sociabilidade e urbanidade (FONTES, 2009, p. 18).

A autora elaborou um quadro (Quadro 5) em que relacionou as funções e atributos dos diferentes tipos de espaços livres e a escala em que ocorrem, com o objetivo de fundamentar seu planejamento. 
Quadro 5: Fundamentos para o planejamento do sistema de espaços livres.

\begin{tabular}{|c|c|c|}
\hline $\begin{array}{l}\text { Escalas dominantes } \\
\text { de Planejamento }\end{array}$ & Tipos de espaços & Funções e atributos \\
\hline \multirow{4}{*}{ Bairro } & $\begin{array}{l}\text { Parques de interesse social- } \\
\text { comunitário. } \\
\text { Praças e parques de pequeno e médio } \\
\text { porte. }\end{array}$ & $\begin{array}{l}\text { Voltados a necessidades do cotidiano } \\
\text { urbano. } \\
\text { Ideal que sejam distribuidos de forma } \\
\text { democrática, privilegiando o pedestre. } \\
\text { Podem oferecer: lazer, descanso, } \\
\text { recreação, esportes, feiras livres, eventos } \\
\text { culturais, trabalhos comunitários, ensino, } \\
\text { produção de alimentos e ervas medicinais. } \\
\text { Podem eventualmente contribuir para a } \\
\text { proteção ambiental. } \\
\text { Muito variáveis em termos de forma, } \\
\text { tamanho e uso, e espaços de médio porte } \\
\text { podem ser multifuncionais. }\end{array}$ \\
\hline & $\begin{array}{l}\text { Verde de proteção ambiental } \\
\text { Inclui Áreas de Preservação Permanente }\end{array}$ & $\begin{array}{l}\text { Amenização de impactos locais, de } \\
\text { pequeno porte. } \\
\text { Controle de erosão, de escoamento } \\
\text { superficial, controle de microclima, } \\
\text { barreira sonora e de poeira. Abrigo de flora } \\
\text { e fauna mais resistentes a alterações } \\
\text { ambientais. }\end{array}$ \\
\hline & $\begin{array}{l}\text { Verde viário } \\
\text { Canteiros centrais e rotatórias, } \\
\text { principalmente. }\end{array}$ & $\begin{array}{l}\text { Para organização de fluxos e } \\
\text { isolamento/distanciamento de vias. } \\
\text { Favorecem a arborização e podem compor } \\
\text { um "corredor verde" integrando diferentes } \\
\text { áreas. } \\
\text { Podem comportar elementos de controle de } \\
\text { escoamento e drenagem. }\end{array}$ \\
\hline & Calçadas & $\begin{array}{l}\text { Podem comportar diversas atividades } \\
\text { sociais, além da arborização que também } \\
\text { pode compor um "corredor verde". Podem } \\
\text { comportar elementos de controle de } \\
\text { escoamento e drenagem. }\end{array}$ \\
\hline \multirow[t]{5}{*}{ Cidade } & $\begin{array}{l}\text { Parques multifuncionais } \\
\text { Praças e parques de médio e grande porte }\end{array}$ & $\begin{array}{l}\text { São também espaços de interesse social, } \\
\text { por isso devem ser acessiveis. Necessário } \\
\text { que sejam distribuidos em função de uma } \\
\text { rede de transportes. Dada a sua amplitude, } \\
\text { têm grande potencial de proteção } \\
\text { ambiental. } \\
\text { Um parque da cidade pode não ter grande } \\
\text { proporção fisica, mas adquire "importância } \\
\text { distrital" devido à sua centralidade e/ou } \\
\text { poder de atração. }\end{array}$ \\
\hline & $\begin{array}{l}\text { Verde de proteção ambiental } \\
\text { Unidades Locais de Conservação e } \\
\text { Áreas de Preservação Permanente }\end{array}$ & $\begin{array}{l}\text { Paisagens protegidas por leis municipais, } \\
\text { Código Florestal (Lei } 4.771 / 65 \text { ) e outros. } \\
\text { Controle de impactos de médio-grande } \\
\text { porte sobre o conjunto da cidade. } \\
\text { Preservação de vegetação singular e abrigo } \\
\text { de fauna. } \\
\text { Controle de erosão, de escoamento } \\
\text { superficial, controle de microclima, } \\
\text { barreira sonora e de poeira. Conservação } \\
\text { de recursos hidricos. }\end{array}$ \\
\hline & Verde viário & Vide acima. \\
\hline & \begin{tabular}{|l|} 
Calçadas \\
\end{tabular} & Vide acima. \\
\hline & Especiais & $\begin{array}{l}\text { Usos especiais que exigem controles sobre } \\
\text { o espaço, restringindo suas potencialidades } \\
\text { sociais ou ambientais, como cemitérios, } \\
\text { campi universitários, horto florestais etc. }\end{array}$ \\
\hline \multirow{3}{*}{ Região } & Parques multifuncionais & $\begin{array}{l}\text { Vide acima. Podem assumir potencial } \\
\text { turístico. }\end{array}$ \\
\hline & Unidades de Conservação & $\begin{array}{l}\text { Protegidas conforme Lei do Sistema } \\
\text { Nacional de Unidades de Conservação - } \\
\text { SNUC (Lei } 9985 / 00 \text { ) e leis especificas. } \\
\text { Podem permitir alguma atividade social de } \\
\text { baixo impacto, desde que de acordo com } \\
\text { Plano de Manejo da unidade. }\end{array}$ \\
\hline & Verde de proteção de estradas & $\begin{array}{l}\text { Similares ao verde viário das cidades. } \\
\text { Podem se associar a corredores verdes e } \\
\text { faixas de proteção de parques e unidades } \\
\text { de conservação. }\end{array}$ \\
\hline
\end{tabular}

Fonte: FONTES, 2009, p. 124-125. 
A partir deste quadro Fontes (2009) apresentou sua classificação e os respectivos parâmetros para os espaços livres da cidade, na qual as categorias cruzaram critérios hierárquicos, como raios de influência de cada espaço, tipologia de espaços segundo suas atribuições e funções, claramente associando as demandas sociais e ambientais por locais de lazer e sociabilidade atrelados à questão da drenagem urbana e proteção do ambiente natural ${ }^{139}$. Embora a escala de seu trabalho principal fosse a do bairro, na intenção de reservar espaços livres públicos em novos loteamentos, a autora explicou que há uma interface com a escala da cidade, uma vez que a área de trabalho se relaciona espacial e funcionalmente com outros espaços livres, mirando a constituição do SEL.

Quadro 6: Parâmetros para praças e parques de função social-lazer.

\begin{tabular}{|c|c|c|c|c|c|}
\hline $\begin{array}{l}\text { Escala } \\
\text { dominante de } \\
\text { planejamento }\end{array}$ & $\begin{array}{l}\text { Função } \\
\text { predominante }\end{array}$ & $\begin{array}{l}\text { Categoria de } \\
\text { Espaço Livre }\end{array}$ & Área & $\begin{array}{l}\text { Distância máxima } \\
\text { do núcleo } \\
\text { habitacional, } \\
\text { priorizando } \\
\text { circuito do } \\
\text { pedestre ou } \\
\text { ciclista }\end{array}$ & Outros atributos \\
\hline \multirow[t]{2}{*}{ Bairro } & Social & $\begin{array}{l}\text { Parque de } \\
\text { vizinhança }\end{array}$ & $\begin{array}{l}\text { A partir de } \\
500 \mathrm{~m}^{2}\end{array}$ & $400 \mathrm{~m}$ & $\begin{array}{l}\text { - Próximo à habitação ou à } \\
\text { margem de área } \\
\text { residencial } \\
\text { isolado de grandes } \\
\text { avenidas - acesso não } \\
\text { deve depender de ruas de } \\
\text { intenso trânsito }\end{array}$ \\
\hline & Social & $\begin{array}{l}\text { Parque de } \\
\text { bairro }\end{array}$ & $\begin{array}{l}\text { A partir de } \\
20.000 \mathrm{~m}^{2}\end{array}$ & $800 \mathrm{~m}$ & $\begin{array}{l}\text { - À margem de área } \\
\text { residencial }\end{array}$ \\
\hline Cidade & Multifuncional & $\begin{array}{l}\text { Parque da } \\
\text { Cidade }\end{array}$ & - & - & $\begin{array}{l}\text { - } \quad \begin{array}{l}\text { Preferencialmente à } \\
\text { margem de área } \\
\text { residencial }\end{array} \\
\end{array}$ \\
\hline \multicolumn{6}{|c|}{$\begin{array}{l}\text { Obs: } \\
\text { - Na primeira e segunda coluna da tabela estão especificadas escalas de planejamento e funções "predominantes" que } \\
\text { não excluem outras que possam coexistir. } \\
\text { - A função social do espaço livre abrange: lazer, descanso, recreação, esporte, comércio em feiras, eventos culturais, } \\
\text { trabalhos comunitários, ensino, produção de alimentos e de ervas medicinais, entre outras. } \\
\text { - Complexos esportivos em que há predomínio de áreas cobertas, não são espaços livres. Campos esportivos ao ar } \\
\text { livre podem fazer parte de um espaço multifuncional ou não, podem ser tidos como parques de Vizinhança, de } \\
\text { Bairro, da Cidade ou Regional, dependendo de seu potencial de atração e capacidade de suporte. }\end{array}$} \\
\hline
\end{tabular}

Fonte: FONTES, 2009, p. 126.

Ao ponderar sobre os critérios para a escolha do tipo de espaço livre para cada setor da cidade, Fontes colocou

\footnotetext{
${ }^{139}$ A respeito das funções específicas para o SEL em Ribeirão Preto, Fontes (2009) distinguiu: função ecológica (conservação de flora, fauna e recursos hídricos); função social-lazer (diversas atividades de interesse da população); função estética-integração (ordenação do sistema viário, organização de fluxos, embelezamento); função ambiental (associada à drenagem, amenização de microclima, controle de poluentes etc.).
} 
Deve-se partir da compreensão sobre as potencialidades e fragilidades do meio físico, das dinâmicas socioeconômicas do setor urbano e dos interesses da comunidade para se determinar prioridades de funções, localização/ distribuição, tamanho das áreas e elementos a implantar (FONTES, 2009, p. 120).

Ela ainda questionou o padrão de destinação de áreas verdes/ sistemas de lazer em função de critérios legais predominantemente quantitativos, que causariam a fragmentação e inadequação socioambiental do espaço urbano e propôs uma metodologia para identificar áreas prioritárias para reserva de espaços livres em novos loteamentos.

Magnoli (2006a) também questionou esse padrão e o quanto ele limita a atuação do profissional de paisagismo, que na escala do lote acaba por trabalhar os recuos das edificações e na escala da cidade atua naqueles espaços definidos pelo sistema viário e os espaços destinados às áreas verdes e à recreação definidos em porcentagem por lei.

Sobre a questão da quantificação, Cavalheiro et al. (1999) questionaram a designação de um índice que determinaria a quantidade de área verde/ espaço livre ${ }^{140}$, vinculado ao suposto padrão ideal de $12 \mathrm{~m}^{2} /$ habitante, que teria sido divulgado pela Organização das Nações Unidas (ONU), informação não confirmada pela instituição de acordo com estes autores.

Para Magnoli (2006b) e Macedo (1995) a questão da quantidade de espaços livres é secundária, sendo mais relevante onde e como estão distribuídos e sobre qual suporte físico, como estabelecem as permeabilidades com a urbanização nas diferentes escalas e frequência de utilização, e como se articulam no SEL, deste modo, transformando a temática dos índices em falsa questão.

De acordo com o levantamento realizado, as categorias para espaços livres são resultado da articulação de múltiplas variáveis, que envolvem parâmetros quantitativos e qualitativos. Na literatura analisada, a combinação dessas diferentes variáveis sustenta a classificação dos espaços livres, a saber: escala planejamento, áreas de influência, dimensão, localização, características do suporte biofísico, função, acessibilidade, situação fundiária,

\footnotetext{
${ }^{140}$ Ademais, haveria discrepâncias quanto adoção da unidade de medida dos índices ( $\mathrm{m}^{2} /$ habitante, $\mathrm{m}^{2} / \mathrm{moradia}$ ou $\mathrm{m}^{2}$ /usuário) e quanto às diferenças metodológicas (por exemplo em relação à adoção de conceitos sobre verde urbano, cobertura vegetal, área de lazer) (VELASCO apud FONTES, 2009 p. 42).
} 
qualificação, legislação, manutenção, relações com o entorno, configuração, usos e apropriações por parte da população, aspectos cênicos entre outras.

Sobre as variáveis que determinam as funções e consequentemente a categoria do espaço livre, Magnoli (2006a, p. 186) colocou que a forma, no sentido de configuração, teria maior influência no desempenho do espaço, pois ela diz respeito à "uma existência física, material, concreta do espaço", que se aproxima do conceito de aptidão do lugar sugerido por McHarg.

Existem outras propostas para categorizar os espaços livres de um Sistema, porém aqui foram levantadas algumas possibilidades que contribuem para a formação de um referencial teórico, tendo em vista as diferentes dimensões da paisagem. Foram encontradas muitas propostas, o que sugere a inexistência de uma padronização e, visto pelo lado positivo, direciona a análise para o contexto específico e para contemplação das diferentes demandas. Magnoli (2006a) e Fontes (2009) concordam que a apropriação de modelos prontos (categorias e funções) de outros países não é uma alternativa satisfatória para classificação dos espaços livres brasileiros, pois estes seriam resultado de uma realidade local, e até mesmo dentro do mesmo país apresentam-se múltiplas realidades.

Os parâmetros levantados aqui são úteis numa primeira etapa do planejamento do SEL, como na seleção e na distribuição das áreas pela cidade, na direção de modificar a lógica de implantação dos espaços livres, que geralmente ocorre de acordo com valores do mercado e os apresenta como espaços residuais de parcelamento do solo ou em função da organização do sistema viário ou, ainda, como elementos embelezadores (MAGNOLI, 2006a; TARDIN, 2008; FONTES, 2009).

Fontes (2009) acrescentou que a categorização pormenorizada do espaço livre tem pouca importância no planejamento, sendo mais relevante garantir sua reserva e sua distribuição pela cidade. Ela ressaltou ainda que por ser um espaço público, faz-se necessário considerar nesse processo, a participação de vários setores da sociedade, assim a categorização pormenorizada e o projeto dos espaços seria elaborado em conjunto com a comunidade interessada, incorporando valores e significados específicos e direcionando suas diretrizes para a apropriação destes espaços pela população e para a proteção ambiental necessária. 


\subsection{Elaboração das categorias para o Sistema de Espaços Livres de São Carlos}

As categorias para o Sistema de Espaços Livres de São Carlos foram fundamentadas no campo disciplinar da Arquitetura da Paisagem e referenciadas pela revisão bibliográfica acerca das categorias de espaços livres e pela legislação vigente, bem como pelas especificidades do contexto da cidade. A sobreposição das cartografias temáticas foi essencial por revelar oportunidades para a proposição do SEL.

Com base no trabalho de pesquisa e análise selecionou-se variáveis determinantes para a elaboração de categorias neste caso específico: características do suporte biofísico; localização/ áreas de influência; função; legislação; dimensão/ configuração; situação fundiária; aspectos cênicos/ visuais/ históricos; qualificação/ infraestrutura; usos e apropriações por parte da população (Quadros 7, 8, 9, 10). Optou-se pelas categorias apreendidas pela observação das cartografias analisadas e que permitiam diferenciar tais espaços ou que foram apreendidas através da experiência na cidade ${ }^{141}$, assim outras variáveis podem ser adicionadas conforme novos dados forem levantados. Esta classificação estabelece uma hierarquia, graus de ocupação/ utilização dos espaços do menos antropizado (Parque de Conservação) ao mais antropizado (Praças), almejando a proteção do ambiente natural e do ser humano como um horizonte a ser alcançado, dado que muitas áreas já estão ocupadas.

${ }^{141}$ A autora residiu na cidade entre os anos 2003 e 2015. 
Quadro 7: Características da Categoria Parques de Conservação.

\begin{tabular}{|c|c|}
\hline \multicolumn{2}{|l|}{ PARQUES DE CONSERVAÇÃO } \\
\hline Características do suporte biofísico & $\begin{array}{l}\text { Possuem características mais naturais como fragmentos de vegetação } \\
\text { significativos ou vegetação nativa, ou vegetação em estágio de } \\
\text { recuperação, podem configurar APPs de córregos e nascentes. O relevo } \\
\text { se distingue por encostas ou várzeas. }\end{array}$ \\
\hline Localização/ áreas de influência & $\begin{array}{l}\text { Bordas da urbanização ou um pouco mais distantes. Utilizados na } \\
\text { escala do bairro e da cidade. }\end{array}$ \\
\hline Função & $\begin{array}{l}\text { Principalmente ambiental-ecológica, no sentido de proteger } \\
\text { ecossistemas, recursos naturais, formas de relevo e solos frágeis e ao } \\
\text { mesmo tempo proteger a população de enchentes, deslizamentos, } \\
\text { bem como promover o controle do microclima (infraestrutura verde). } \\
\text { Definir limites à expansão urbana, formando um cinturão verde, e } \\
\text { estabelecer uma interface com a área rural. } \\
\text { Promover o contato da população com a natureza e seus ciclos, } \\
\text { despertar o cuidado com ambiente natural. }\end{array}$ \\
\hline Legislação & $\begin{array}{l}\text { Paisagens protegidas por leis municipais (APREM, AIA do Plano Diretor) } \\
\text { e/ ou federais (Código Florestal). }\end{array}$ \\
\hline Dimensão/ configuração & $\begin{array}{l}\text { Áreas extensas se comparadas às outras categorias. Apresentam } \\
\text { configuração linear e situações de alargamento, podem envolver } \\
\text { outras categorias de parques. }\end{array}$ \\
\hline Situação fundiária & Considera espaços públicos e privados. \\
\hline $\begin{array}{lll}\text { Aspectos cênicos/ visuais/ } \\
\text { históricos }\end{array}$ & Podem abranger paisagens notáveis devido ao relevo ou à vegetação. \\
\hline Qualificação/ infraestrutura & $\begin{array}{l}\text { Podem conter trilhas (não pavimentadas), pontos de observação da } \\
\text { natureza. }\end{array}$ \\
\hline $\begin{array}{l}\text { Usos e apropriações por parte da } \\
\text { população }\end{array}$ & $\begin{array}{l}\text { Sugere-se o uso mais restrito em comparação às outras categorias. } \\
\text { Utilização relacionada a recreação, contemplação da natureza, } \\
\text { pesquisa científica e educação ambiental. }\end{array}$ \\
\hline
\end{tabular}

Fonte: Elaborado pela autora. 
Quadro 8: Características da Categoria Parques Lineares.

\begin{tabular}{|c|c|}
\hline \multicolumn{2}{|l|}{ PARQUES LINEARES } \\
\hline Características do suporte biofísico & $\begin{array}{l}\text { Podem apresentar fragmentos de vegetação significativos ou vegetação } \\
\text { em estágio de recuperação, que configuraram APPs de córregos, ou } \\
\text { podem ser áreas de urbanização consolidada. Apresentam-se } \\
\text { principalmente como fundos de vale e várzeas. }\end{array}$ \\
\hline Localização/áreas de influência & $\begin{array}{l}\text { Localizam-se dentro do perímetro urbano, distribuídos por toda cidade. } \\
\text { Utilizados na escala do bairro e da cidade. }\end{array}$ \\
\hline Função & $\begin{array}{l}\text { Principalmente a conectividade, entre ecossistemas, lugares, pessoas. } \\
\text { Constituem um dos elos do sistema. Funcionam como corredores } \\
\text { verdes e de circulação de ar, portanto, estão associados ao controle do } \\
\text { microclima. } \\
\text { Função ambiental-ecológica, proteção de APPs eáreas ambientalmente } \\
\text { sensiveis e sujeitas a inundações. Associadas à drenagem natural, } \\
\text { podem proteger a população de enchentes, deslizamentos. } \\
\text { Atrelados à ferrovia, visam ampliar as condições de visibilidade da } \\
\text { chamada Paisagem Cultural, bem como atuar na proteção do } \\
\text { patrimônio histórico-cultural. }\end{array}$ \\
\hline Legislação & $\begin{array}{l}\text { Paisagens protegidas por leis municipais (APREM, AIA do Plano Diretor) } \\
\text { e/ ou federais (Código Florestal), com vários conflitos instalados a partir } \\
\text { de ocupação ilegal. }\end{array}$ \\
\hline Dimensão/ configuração & $\begin{array}{l}\text { Apresentam configuração linear atrelada aos cursos d'água, vias e } \\
\text { ferrovia, podem estar adjacentes às outras categorias de parques. }\end{array}$ \\
\hline Situação fundiária & Considera espaços públicos e privados. \\
\hline $\begin{array}{lll}\text { Aspectos } & \text { cênicos/ visuais/ } \\
\text { históricos } & & \end{array}$ & Paisagens urbanizadas e históricas (por exemplo, a ferrovia). \\
\hline Qualificação/ infraestrutura & $\begin{array}{l}\text { Podem incluir ciclovias, vias arborizadas, percursos pavimentados, } \\
\text { equipamentos de lazer e esportes, estares. }\end{array}$ \\
\hline $\begin{array}{l}\text { Usos e apropriações por parte da } \\
\text { população }\end{array}$ & $\begin{array}{l}\text { Usos atrelados à circulação, passeio, contemplação, recreação, lazer, } \\
\text { esportes etc. }\end{array}$ \\
\hline
\end{tabular}

Fonte: Elaborado pela autora. 
Quadro 9: Características da Categoria Parques Urbanos.

\begin{tabular}{|c|c|}
\hline \multicolumn{2}{|l|}{ PARQUES URBANOS } \\
\hline Características do suporte biofísico & $\begin{array}{l}\text { Podem apresentar fragmentos de vegetação significativos ou } \\
\text { vegetação dispersa. Podem ser áreas bastante antropizadas e } \\
\text { modificadas. Apresentam-se em relevos variados e nas proximidades } \\
\text { de cursos d'água. }\end{array}$ \\
\hline Localização/ áreas de influência & $\begin{array}{l}\text { Localizam-se dentro do perímetro urbano, distribuídos por toda } \\
\text { cidade. Utilizados na escala do bairro e da cidade. }\end{array}$ \\
\hline Função & $\begin{array}{l}\text { Espaços multifuncionais; podem ter função ambiental-ecológica e de } \\
\text { infraestrutura verde. }\end{array}$ \\
\hline Legislação & $\begin{array}{l}\text { Podem ser paisagens protegidas por leis municipais (APREM, AIA do } \\
\text { Plano Diretor) e/ ou federais (Código Florestal). }\end{array}$ \\
\hline Dimensão/ configuração & $\begin{array}{l}\text { Espaços relativamente menores e geralmente delimitados, integrados } \\
\text { às outras categorias de parques. }\end{array}$ \\
\hline Situação fundiária & Considera apenas espaços públicos. \\
\hline Aspectos cênicos/visuais/ históricos & $\begin{array}{l}\text { Paisagens urbanizadas, e históricas (Parque da Chaminé). Podem } \\
\text { abranger paisagens notáveis devido ao relevo ou à vegetação. }\end{array}$ \\
\hline Qualificação/ infraestrutura & $\begin{array}{l}\text { Tratamento paisagístico, percursos pavimentados, equipamentos de } \\
\text { lazer e esportes, estares etc. }\end{array}$ \\
\hline $\begin{array}{l}\text { Usos e apropriações por parte da } \\
\text { população }\end{array}$ & $\begin{array}{l}\text { Lazer, descanso, recreação, esportes, feiras livres, eventos, horta } \\
\text { urbana, educação ambiental entre outros. } \\
\text { Espaços que já apresentam usos consolidados ou espaços à espera de } \\
\text { qualificação. }\end{array}$ \\
\hline
\end{tabular}

Fonte: Elaborado pela autora.

Quadro 10: Características da Categoria Praças.

\begin{tabular}{|c|c|}
\hline \multicolumn{2}{|l|}{ PRAÇAS } \\
\hline Características do suporte biofísico & $\begin{array}{l}\text { Podem apresentar fragmentos de vegetação significativos ou } \\
\text { vegetação dispersa. Áreas comumente bastante antropizadas e } \\
\text { modificadas. Apresentam-se em relevos variados. }\end{array}$ \\
\hline Localização/ áreas de influência & $\begin{array}{l}\text { Localizam-se dentro do perímetro urbano, distribuídas por toda } \\
\text { cidade. Utilizadas geralmente na escala do bairro, com exceção das } \\
\text { praças centrais, que por estarem associadas aos pontos de transporte } \\
\text { público coletivo, recebem pessoas de todos os setores da cidade. }\end{array}$ \\
\hline Função & $\begin{array}{l}\text { Espaços multifuncionais. Podem estar associadas aos equipamentos e } \\
\text { serviços públicos, ao patrimônio e comércio. Podem ter função } \\
\text { ambiental-ecológica e de infraestrutura verde. }\end{array}$ \\
\hline Legislação & $\begin{array}{l}\text { Podem ser paisagens protegidas por leis municipais (APREM, AIA do } \\
\text { Plano Diretor) e/ ou federais (Código Florestal). }\end{array}$ \\
\hline Dimensão/ configuração & $\begin{array}{l}\text { Espaços relativamente menores e normalmente delimitados, variáveis } \\
\text { em termos de forma. Espaços livres e áreas verdes originárias de } \\
\text { parcelamento do solo. }\end{array}$ \\
\hline Situação fundiária & Considera apenas espaços públicos. \\
\hline Aspectos cênicos/visuais/ históricos & $\begin{array}{l}\text { Paisagens urbanizadas, e/ou vinculadas ao patrimônio histórico } \\
\text { cultural. }\end{array}$ \\
\hline Qualificação/ infraestrutura & $\begin{array}{l}\text { Quando presentes, tratamento paisagístico, percursos pavimentados, } \\
\text { equipamentos de lazer e esportes, estares etc. }\end{array}$ \\
\hline $\begin{array}{l}\text { Usos e apropriações por parte da } \\
\text { população }\end{array}$ & $\begin{array}{l}\text { Lazer, descanso, recreação, esportes, feiras livres, eventos, entre } \\
\text { outros. } \\
\text { Espaços que já apresentam usos consolidados ou espaços à espera de } \\
\text { qualificação. }\end{array}$ \\
\hline
\end{tabular}

Fonte: Elaborado pela autora. 
A multiplicidade de atribuições dos espaços livres contemporâneos indica uma abordagem interdisciplinar que atualiza as abordagens originais do campo da Arquitetura da Paisagem e suscita sua possível distinção em novas categorias que, deste modo, estarão sujeitas a adequações e adaptações em relação ao fenômeno e às demandas da população.

Apesar do conhecimento sobre a cidade, fruto da experiência vivida, foram encontradas dificuldades ao elaborar os quadros de categorias, por exemplo, quanto às áreas de influência, o que demandaria um estudo mais aprofundado com ferramentas adequadas para tal fim; quanto à designação da vegetação presente nos espaços, indicando a verificação por um especialista; quanto ao refinamento das definições das variáveis "infraestrutura", "usos", "funções", que se assemelham em alguns aspectos. Observou-se também que a maior parte dos espaços contemplados neste SEL são protegidos pela legislação e, no entanto, muitos encontram-se ocupados, sendo alguns casos anteriores aos regulamentos, como as margens dos córregos do centro da cidade.

O SEL deste trabalho fundamenta-se nas cartografias levantadas e nos princípios da Arquitetura da Paisagem, portanto expressa uma das possibilidades de Sistema, pois podem ser adicionadas outras cartografias ${ }^{142}$ de modo a conformar um SEL diferente.

O mapa 12 apresenta o Sistema de Espaços Livres para São Carlos e as categorias de espaços livres, resultado das ações sobre o mapa síntese (mapa 11), organizadas no quadro 11, na sequência. O Sistema proposto encontra-se no âmbito do planejamento e representa a conquista da área de projeto.

\footnotetext{
${ }^{142}$ No processo de elaboração do SEL, tendo vista o referencial teórico abordado e as especificidades de São Carlos, identificou-se a necessidade de outras cartografias que agregariam ao trabalho, tais como mapa censitário, mapas sobre relevo e solos (declividade, hipsometria, pedologia), imagem termal (indicando a variação da temperatura em relação à cobertura vegetal) que, no entanto, não foram localizados.
} 


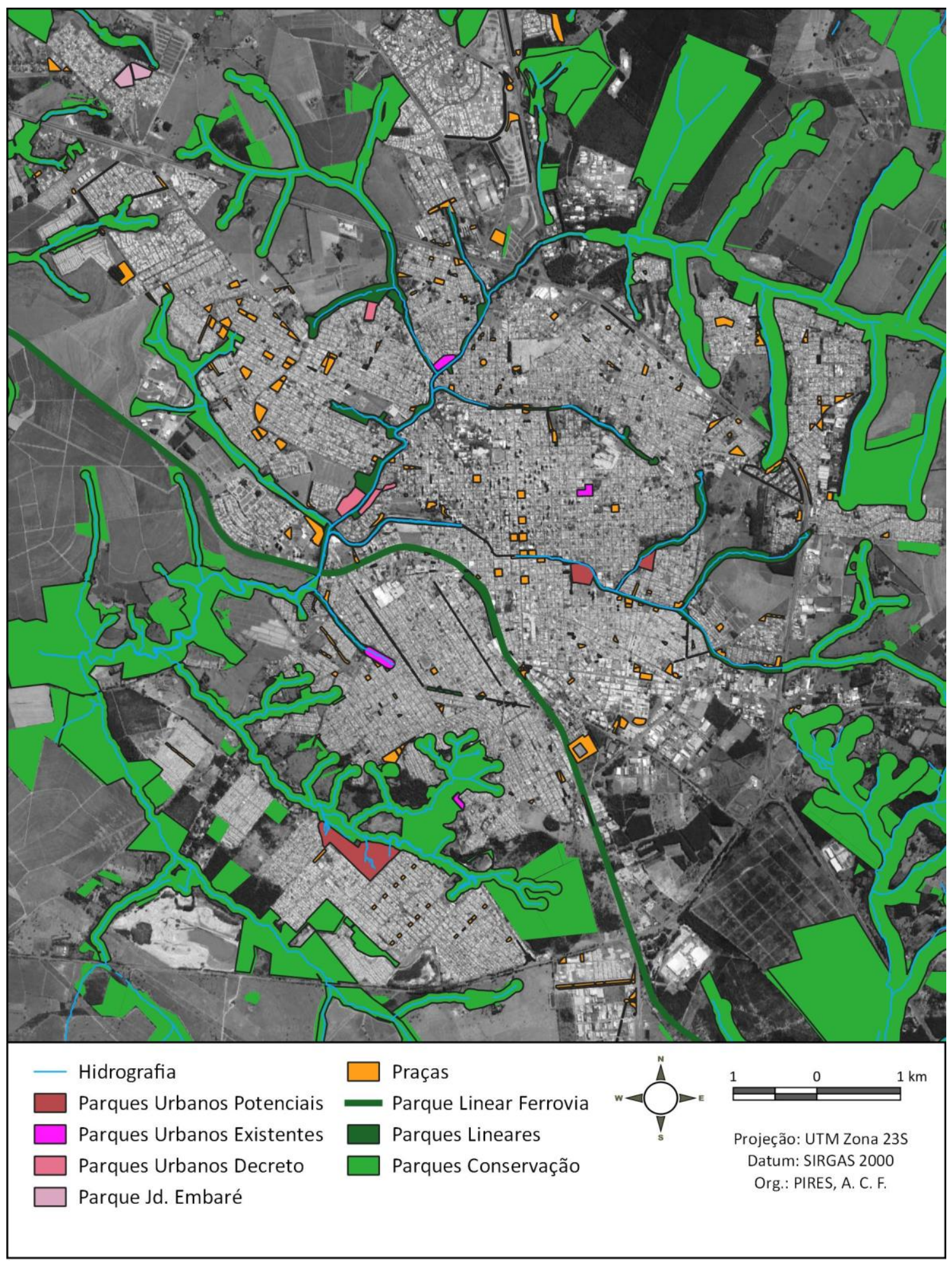

Mapa 12: Sistema de Espaços Livres para São Carlos.

Fonte: Elaborado pela autora com base em Google Satellite, 2019; PMSC, 2019; PMSC, 2016; SÃO CARLOS, 2006; SÃO CARLOS, 2016; SÃO CARLOS, 2017; SÃO CARLOS, 2019; BRASIL, 2018. 
Quadro 11: Ações sobre o Mapa Síntese para elaboração do Sistema de Espaços Livres.

\begin{tabular}{|c|c|c|}
\hline CATEGORIAS & MAPA BASE & MODIFICAÇÕES \\
\hline $\begin{array}{l}\text { PARQUES DE } \\
\text { CONSERVAÇÃOO }\end{array}$ & $\begin{array}{l}\text { Mapa } 8 \text { - Imagem de São Carlos, } \\
\text { Hidrografia, Áreas de Especial } \\
\text { Interesse Ambiental (AIA), Subárea de } \\
\text { Preservação } 1 \text { (SAPRE 1) e Subárea de } \\
\text { Preservação } 2 \text { (SAPRE 2), Reserva } \\
\text { Legal. }\end{array}$ & $\begin{array}{l}\text { Foram considerados Parques de Conservação: as SAPREs } 1 \text { e } 2 \text { que sobrepõem às AIA; o Sítio do Melo e o Parque do Espraiado } \\
\text { (ambos parques do decreto no170/2017). As APPs, afluentes e áreas vegetadas adjacentes aos córregos Água Quente e Água } \\
\text { Fria, mesmo estando em áreas urbanizadas apresentam fragilidade ambiental (solos e encosta), além de pertencerem ao projeto } \\
\text { Biota da FAPESP, por esses motivos também foram consideradas nesta categoria. Em relação ao restante das AIA, foram } \\
\text { mantidas nesta categoria: córrego Mineirinho e afluentes; córrego Santa Maria do Leme e afluentes localizados na Macrozona } \\
\text { de Expansão Urbana (conforme Plano Diretor Estratégico 2016); e as nascente do córrego Gregório. Foram adicionadas as APPs } \\
\text { rurais do córrego Monjolinho à sudoeste da cidade, que não constavam nas cartografias, de modo a configurar um cinturão } \\
\text { verde. As Reservas Legais foram consideradas nesta categoria. }\end{array}$ \\
\hline $\begin{array}{l}\text { PARQUES } \\
\text { LINEARES }\end{array}$ & $\begin{array}{l}\text { Mapa } 8 \text { - Imagem de São Carlos, } \\
\text { Hidrografia, Áreas de Especial } \\
\text { Interesse Ambiental (AIA), Subárea de } \\
\text { Preservação } 1 \text { (SAPRE 1) e Subárea de } \\
\text { Preservação } 2 \text { (SAPRE } 2 \text { ), Reserva } \\
\text { Legal. }\end{array}$ & $\begin{array}{l}\text { Considerou-se apenas as APPs urbanas em áreas consolidadas. Foram adicionadas Av. Teixeira de Barros, Av. Grécia, Av. } \\
\text { Henrique Gregori, que possuem canteiros centrais arborizados e estares, locais já utilizados pela população como Parque Linear. } \\
\text { Visando a proteção, a nascente do córrego Cambuí (afluente do córrego Santa Maria do Leme) e área vegetada adjacente ao } \\
\text { córrego Santa Maria do Leme (ambas referentes aos parques do decreto) foram incorporados nesta categoria por se localizarem } \\
\text { na área de transição para Macrozona de Expansão Urbana. Foram realizados alguns ajustes devido a confrontação com a } \\
\text { realidade (através da observação no mapa), como no caso de APPs ocupadas. Por fim, propõe-se a desativação da linha férrea } \\
\text { na área urbana e seu desvio para área rural, de forma a transformá-la, juntamente com a Estação Ferroviária, em Parque Linear } \\
\text { associado ao patrimônio. }\end{array}$ \\
\hline $\begin{array}{l}\text { PARQUES } \\
\text { URBANOS }\end{array}$ & $\begin{array}{l}\text { Mapa 10: Imagem de São Carlos, } \\
\text { Hidrografia, Parques Existentes, } \\
\text { Parques do Decreto, Parque } \\
\text { adicionado (Jd. Embaré). }\end{array}$ & $\begin{array}{l}\text { Em relação aos parques dos decretos, considerou-se como Parque Urbano apenas as áreas: Bosque Santa Marta, Parque das } \\
\text { Artes (as duas áreas) e o Parque do Embaré. Excluiu-se as outras áreas: Parque do Espraiado; Sítio do Melo (pertencem a AIA); } \\
\text { Parque do Aracy (fragilidade ambiental solos e encosta, também pertence a AIA), pois foram incorporadas aos Parques de } \\
\text { Conservação. Foram adicionados locais já cotados pela municipalidade para serem parques como o Parque da Chaminé, o } \\
\text { Parque das Cerejeiras, o Parque na Cidade Aracy na margem esquerda do córrego Água Quente (não é o do decreto), que } \\
\text { envolvem áreas do Sistema de Recreio, Área Institucional, e pertence à AIA. }\end{array}$ \\
\hline PRAÇAS & $\begin{array}{l}\text { Mapa 9: Imagem de São Carlos, } \\
\text { Hidrografia, Sistema de Recreio, Áreas } \\
\text { Institucionais. }\end{array}$ & $\begin{array}{l}\text { Exclusão das áreas significativamente vegetadas e sem uso consolidado, sobrepostas ou adjacentes às APPs contidas nas AIA, } \\
\text { pois serão incorporadas aos Parques de Conservação como forma de ampliar estas áreas relevantes à manutenção do ciclo } \\
\text { hídrico e da drenagem urbana, evitando que sejam impermeabilizadas. As praças já consolidadas, que pertencem } \\
\text { simultaneamente ao Sistema de Recreio e às AIA foram mantidas. Também foram excluídos os canteiros centrais da Av. Grécia } \\
\text { e da Av. Henrique Gregori, que pertencem a categoria de Parques Lineares. Não foram consideradas as áreas institucionais que } \\
\text { pertencem à camada AIA. }\end{array}$ \\
\hline
\end{tabular}

Fonte: Elaborado pela autora. 
Os mapas $13,14,15$ e 16 demonstram separadamente cada uma das categorias constituintes do SEL, seguidos de fotos que retratam alguns dos espaços.

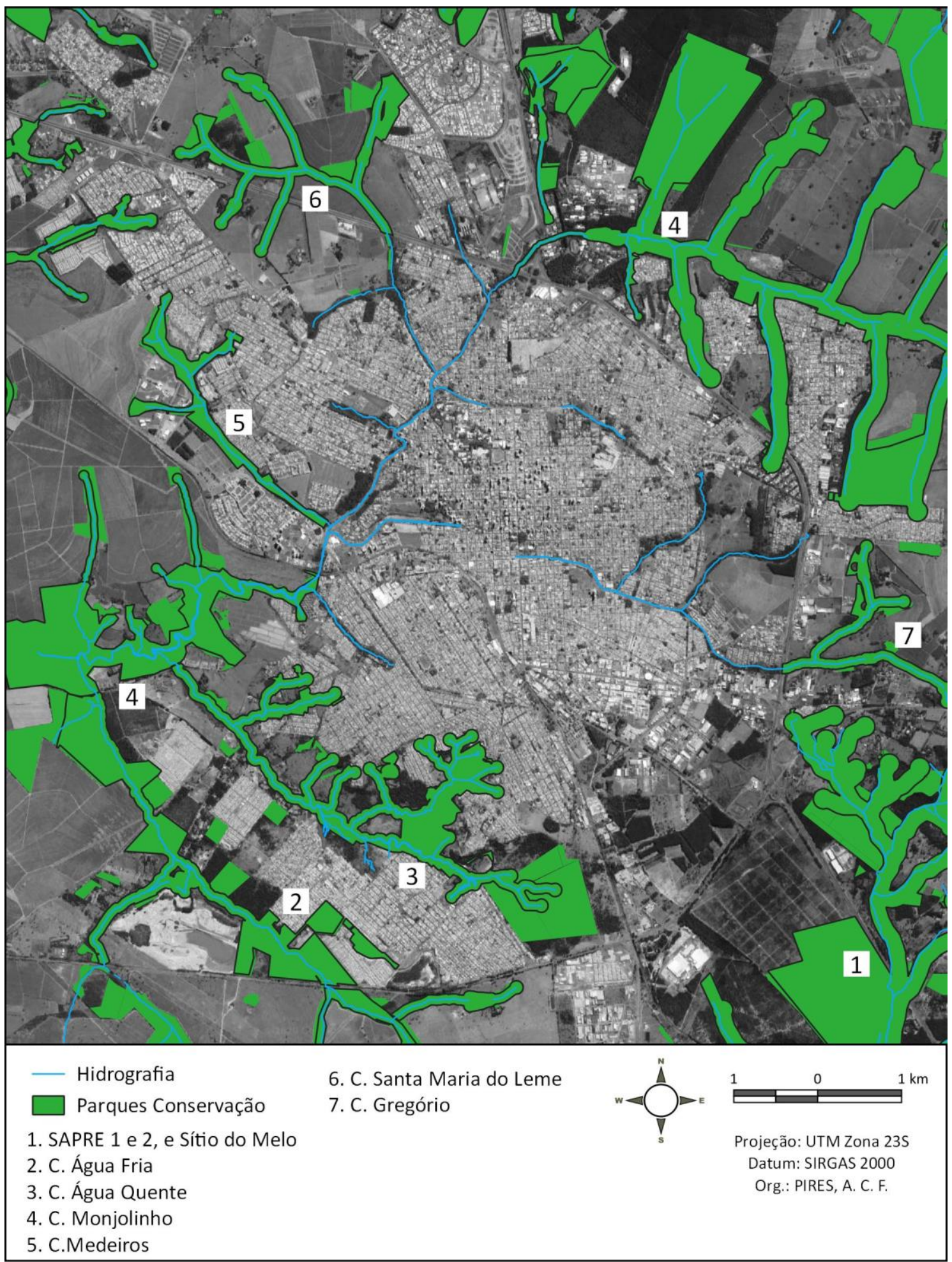

Mapa 13: Parques de Conservação do Sistema de Espaços Livres de São Carlos.

Fonte: Elaborado pela autora com base em Google Satellite, 2019; PMSC, 2019; PMSC, 2016; SÃO CARLOS, 2006; SÃO CARLOS, 2016; SÃO CARLOS, 2017; SÃO CARLOS, 2019; BRASIL, 2018. 


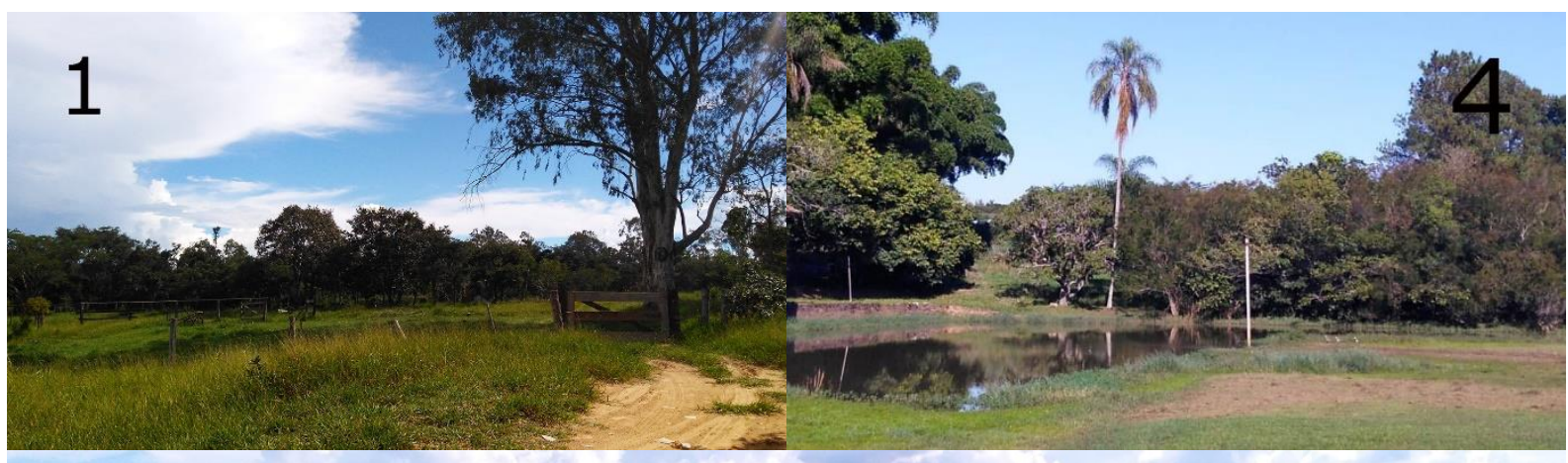

\section{3}

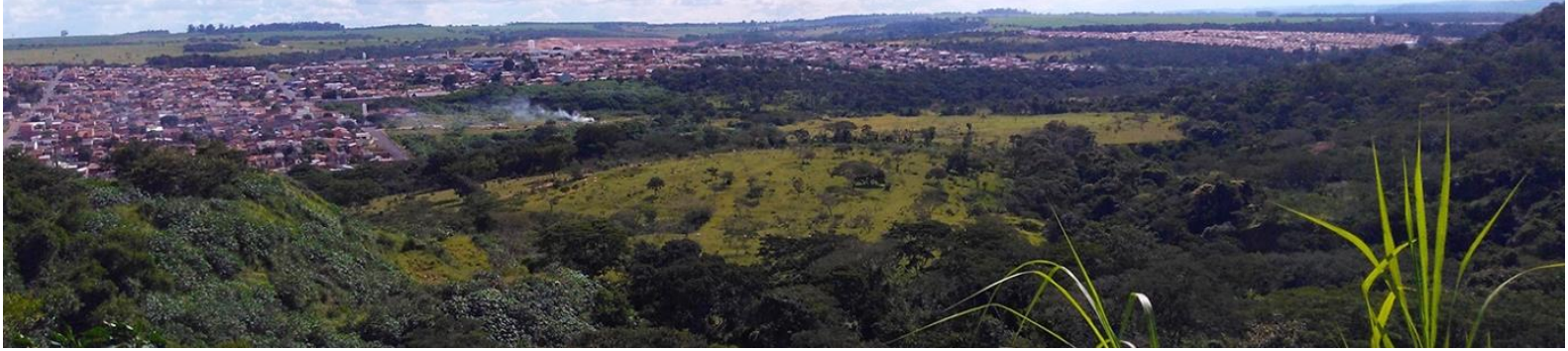

Figura 47: Parques de Conservação: 1) Sítio do Melo; 4) Parque do Monjolinho-Espraiado; 3) Córrego Água Quente (a numeração indica a localização no mapa 13).

Fonte: Acervo da autora, 2018.

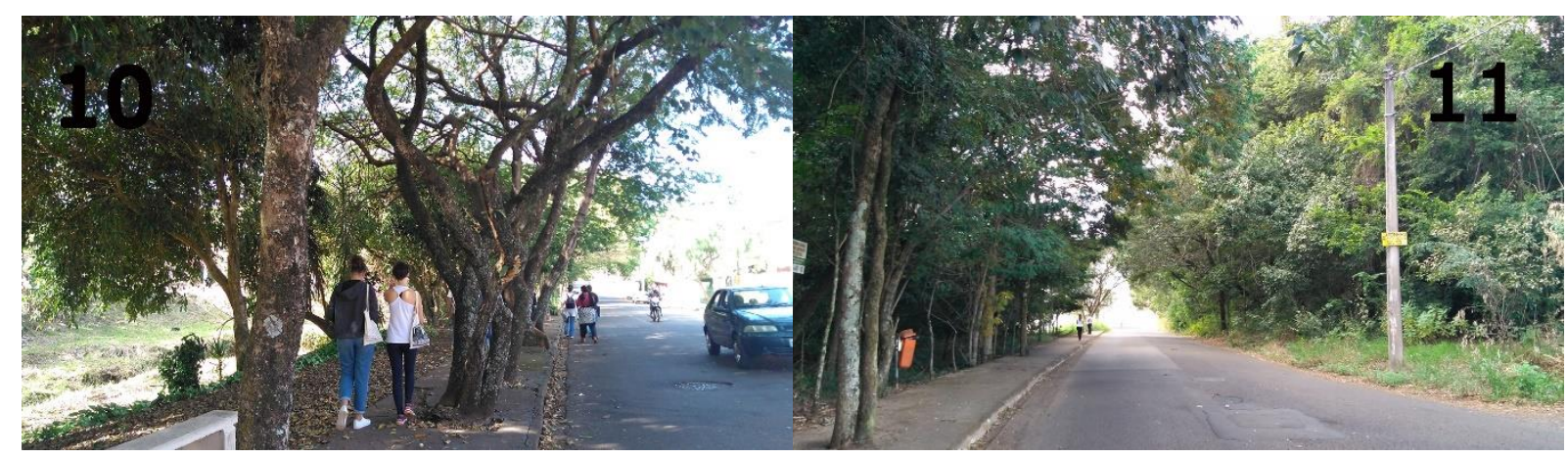

Figura 48: Parques Lineares: 10) Córrego Santa Maria; 11) Córrego Cambuí (a numeração indica a localização no mapa 14).

Fonte: Acervo da autora, 2019. 


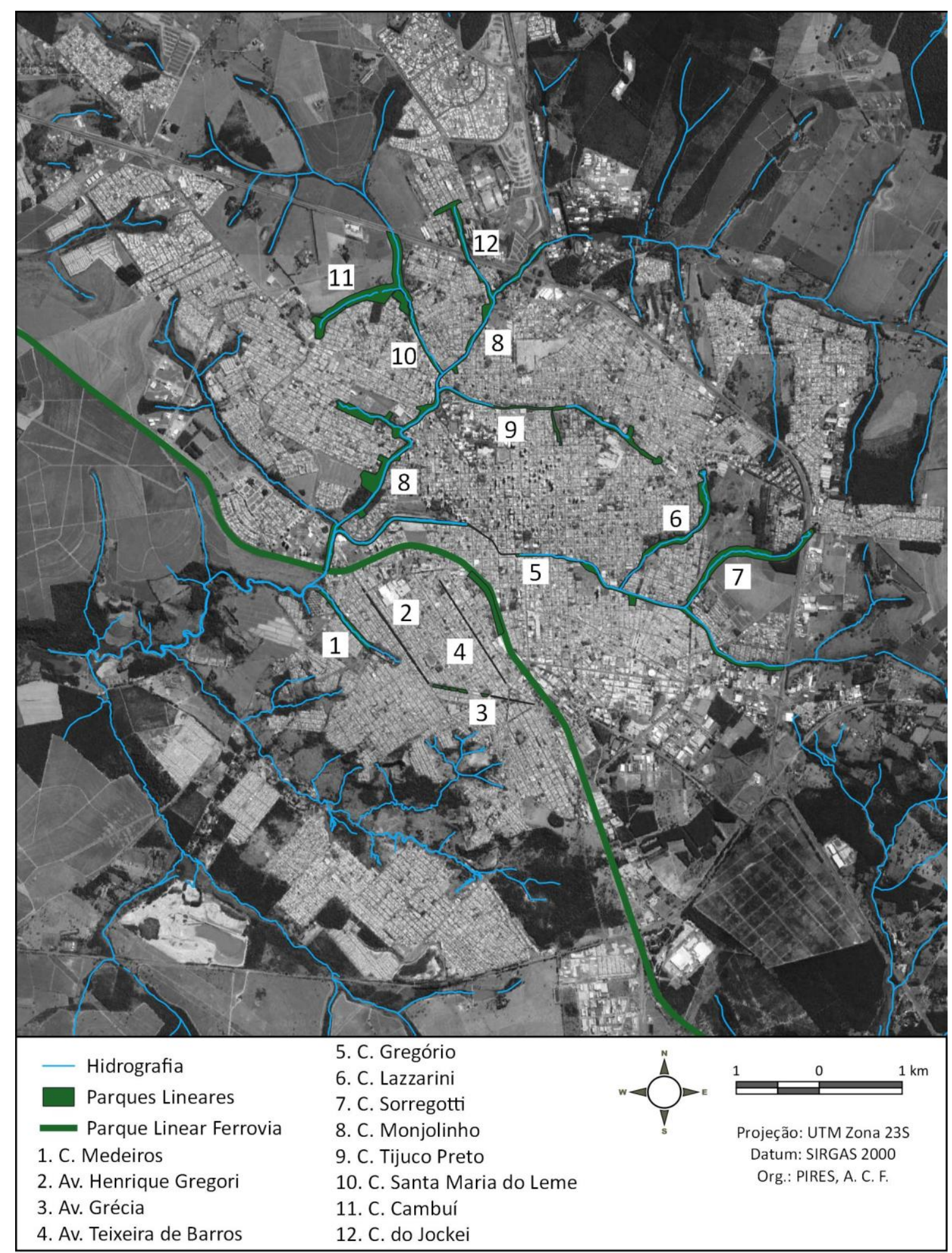

Mapa 14: Parques Lineares do Sistema de Espaços Livres de São Carlos.

Fonte: Elaborado pela autora com base em Google Satellite, 2019; PMSC, 2019; PMSC, 2016; SÃO CARLOS, 2006; SÃO CARLOS, 2016; SÃO CARLOS, 2017; SÃO CARLOS, 2019; BRASIL, 2018. 


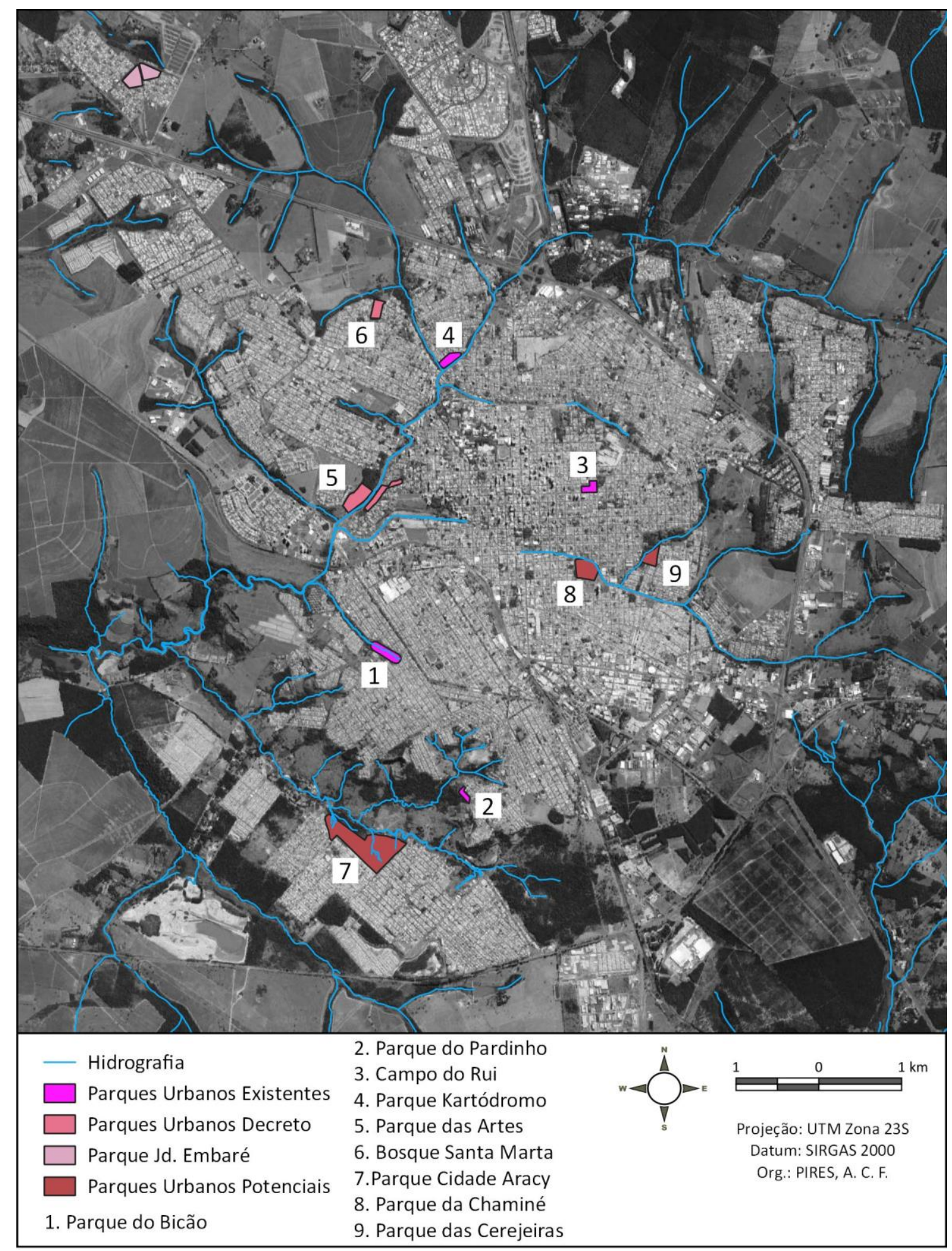

Mapa 15: Parques Urbanos do Sistema de Espaços Livres de São Carlos.

Fonte: Elaborado pela autora com base em Google Satellite, 2019; PMSC, 2019; PMSC, 2016; SÃO CARLOS, 2006; SÃO CARLOS, 2016; SÃO CARLOS, 2017; SÃO CARLOS, 2019; BRASIL, 2018. 


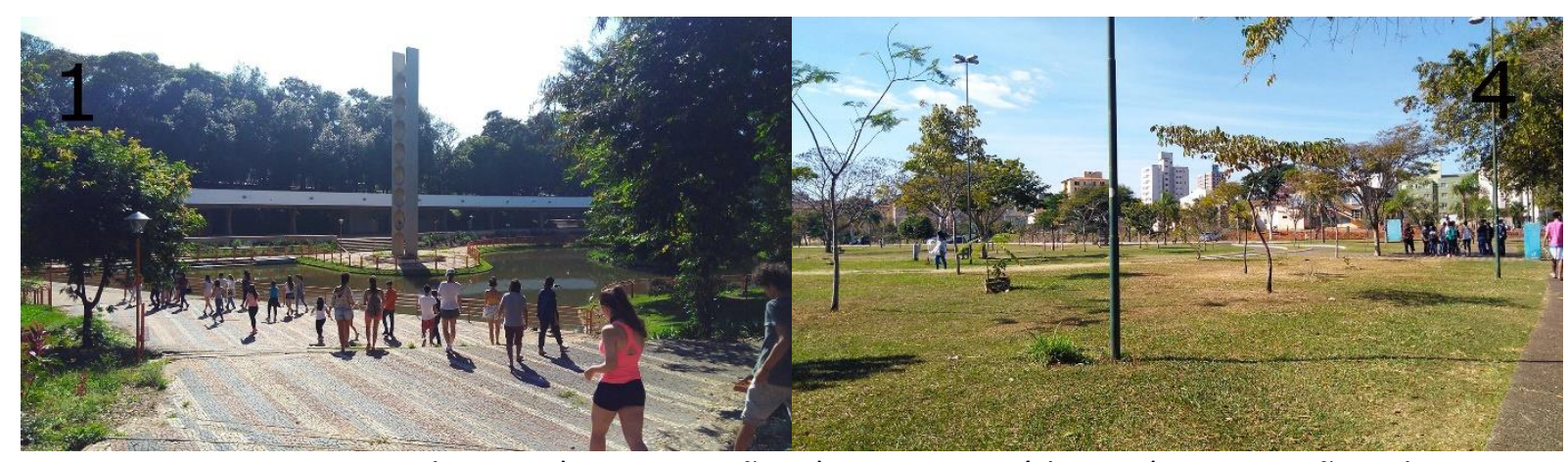

Figura 49: Parques Urbanos: 1) Parque Bicão; 4) Parque Kartódromo (a numeração indica a localização no mapa 15).

Fonte: Acervo da autora, 2018.

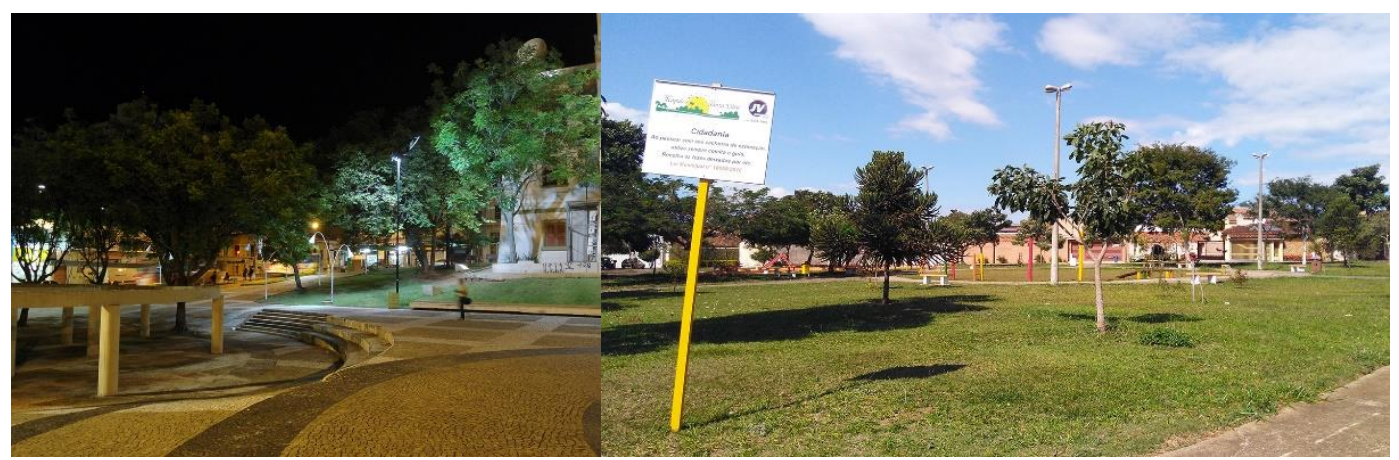

Figura 50: Praças: a esquerda, Praça Coronel Salles no centro da cidade; a direita, Praça no bairro J. Santa Paula.

Fonte: Acervo da autora, 2015 e 2019. 


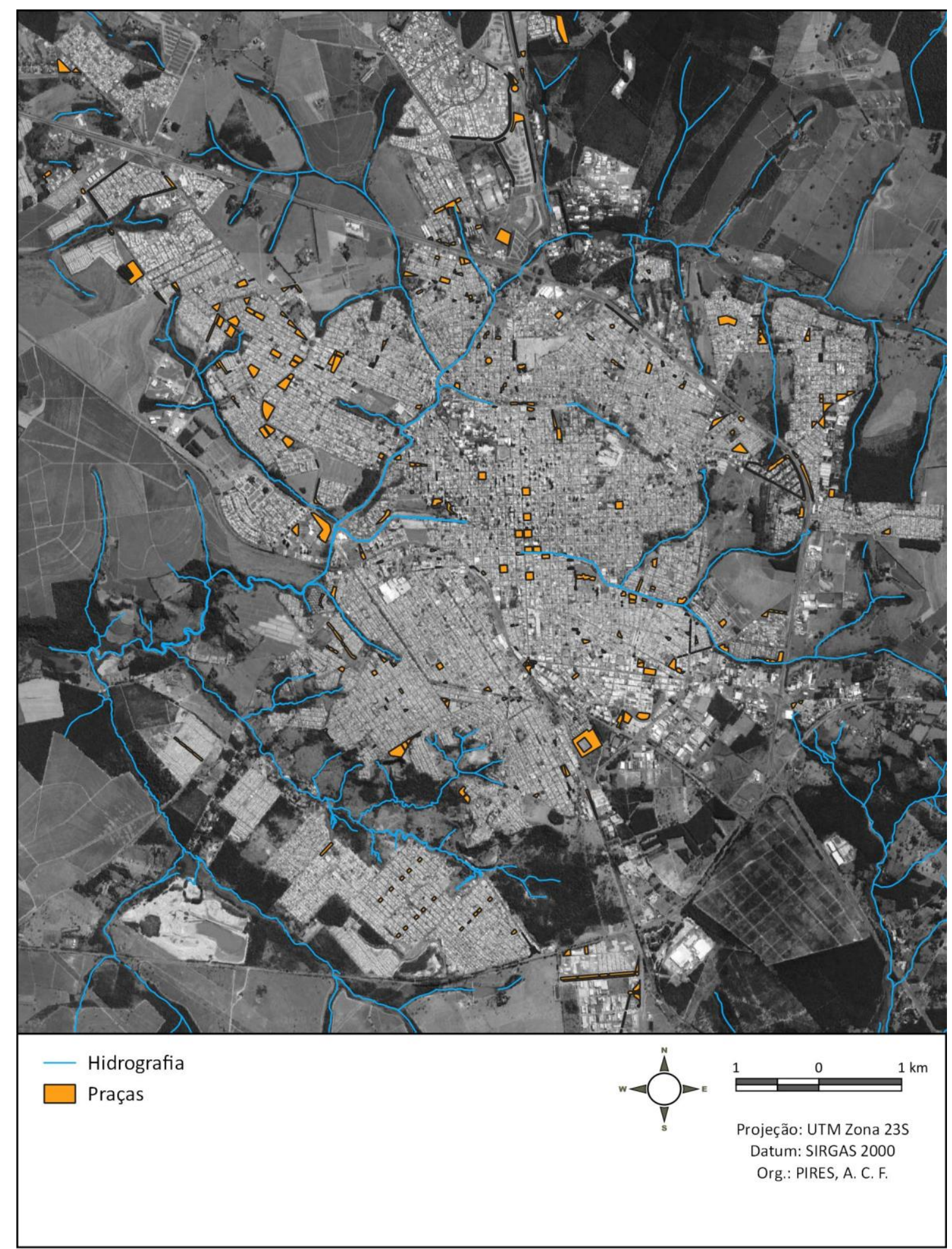

Mapa 16: Praças do Sistema de Espaços Livres de São Carlos.

Fonte: Elaborado pela autora com base em Google Satellite, 2019; PMSC, 2019; PMSC, 2016; SÃO CARLOS, 2006; SÃO CARLOS, 2016; SÃO CARLOS, 2017; SÃO CARLOS, 2019; BRASIL, 2018. 
O mapa 12 expõe uma possibilidade de Sistema de Espaços Livres para São Carlos com objetivo de salvaguardar espaços livres relevantes do ponto de vista ambiental e social. Esta ação também demonstra uma alternativa ao planejamento urbano tradicional, que termina por distinguir estes espaços como resíduos do parcelamento. Ao considerar a aptidão de cada espaço e representá-los nesta cartografia, pretende-se inverter a lógica de planejamento, direcionando a expansão para locais mais adequados para esta finalidade.

Apresenta-se aqui o desenvolvimento de uma estratégia metodológica que utiliza chaves de investigação calcadas na sobreposição cartográfica, em estreito diálogo com o desenvolvimento tecnológico atual, permitindo o cruzamento de informações que são representadas separadamente pelos documentos oficiais. Há nessa ação de escolha uma valoração, pois os mapas convocados no processo juntam disposições legais e presenças, numa clara cumplicidade que mira na constituição do Sistema de Espaços Livres. Deste modo, o resultado é uma base de dados, representados na cartografia do SEL, em que se anuncia o levantamento preliminar desses espaços e sua classificação em categorias. Tais informações podem subsidiar o poder público e profissionais da área de planejamento urbano, bem como de projeto de arquitetura da paisagem na proposição do SEL.

Essa estratégia visa conquistar e construir espaços livres de sociabilização e proteção, assim como permitir uma potencial aproximação aos processos naturais a partir de seu desenho, incentivando a mudança do padrão de percepção da natureza e, desta forma, busca assegurar a proteção desses lugares. Deseja-se ainda nesse percurso, trazer visibilidade aos espaços, proporcionada não só pelas diretrizes dessa matriz de planejamento, que tem em sua estrutura forte diálogo com a paisagem e suas dimensões, mas também pela construção de representações cujas informações possam ser disponibilizadas para a população.

A construção de representações ocorre por meio da elaboração de cenários, que auxiliem a compreensão do projeto de parque. Para tanto, a etapa seguinte ${ }^{143}$ consiste no refinamento da proposta por meio do trânsito de escalas através da visita a campo: palmilhar o território na escala do fenômeno é experenciar o cotidiano desse lugar, confrontando a cartografia do SEL com a realidade dos espaços.

\footnotetext{
${ }^{143}$ Esta etapa não é o foco da dissertação, mas pertence a estratégia metodológica para Planejar com a Paisagem, por esse motivo foi apresentada para ilustrar o trânsito de escalas e os cenários possíveis. As atividades e discussões sobre essa etapa foram realizadas junto ao GTPU.
} 
As visitas a campo têm como recorte territorial uma microbacia hidrográfica escolhida, na qual se planeja um percurso (mapa 17), um roteiro predeterminado, indicando pontos de interesse a serem explorados. Porém, o contato com lugar acaba naturalmente suscitando novas percepções e, por meio de um estado de atenção difusa (LIMA, 2019), capta-se novos estímulos, a realidade adquire perfis diversos que são registrados em fotografias, croquis, diagramas. O roteiro planejado é então modificado e os novos dados obtidos em campo compõe a denominada cartografia "quente", em distinção à chamada cartografia "fria" referente ao SEL na escala do sobrevoo da etapa anterior.

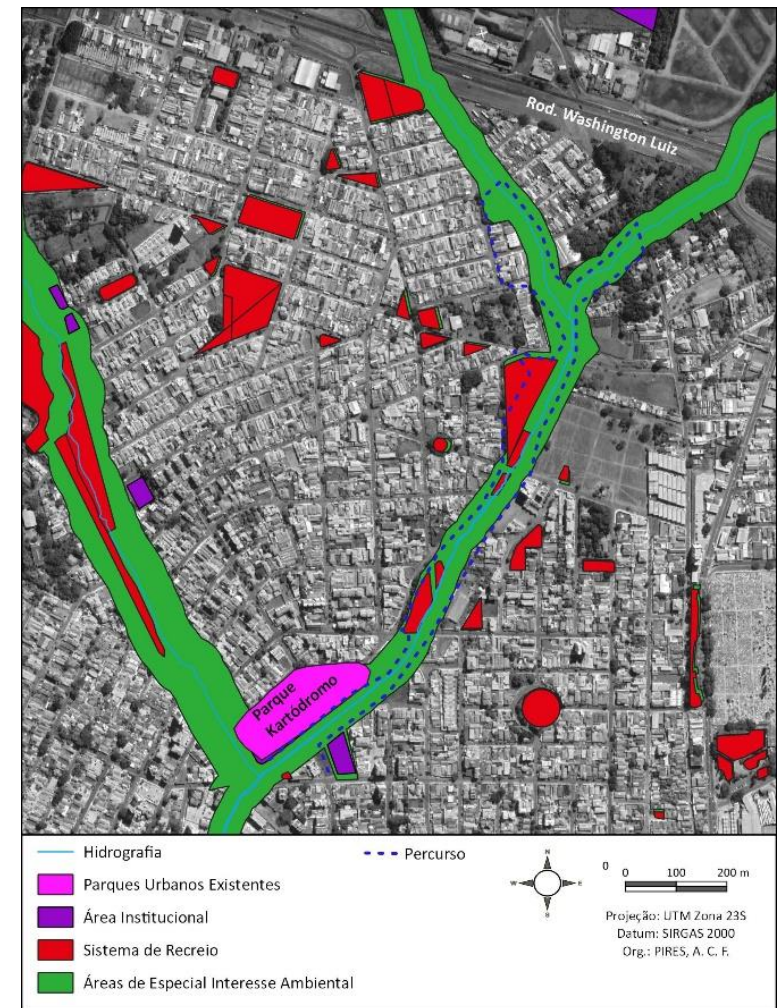

Mapa 17: Recorte do Mapa Síntese que apresenta parte da microbacia do Córrego Monjolinho, trecho parque Kartódromo até as proximidades da rodovia Washington Luiz, e o percurso realizado. Fonte: Elaborado pela autora com base em Google Satellite, 2019; PMSC, 2019; PMSC, 2016; SÃO

CARLOS, 2016.

Para esta etapa foi escolhida a microbacia hidrográfica do Córrego Monjolinho, categorizado como Parque Linear no SEL proposto, especificamente o trecho (mapa 17) com início no parque Kartódromo e Córrego Santa Maria do Leme até as proximidades da rodovia Washington Luiz. O mapa 17 mostra o percurso ao longo do córrego Monjolinho e as áreas públicas adjacentes incorporadas ao projeto. Na análise da cartografia quente (figura 51) 
destacam-se as potencialidades dos espaços livres verificadas durante o percurso, a partir das quais são formuladas as diretrizes para orientar o projeto do parque (figuras 52 e 53).

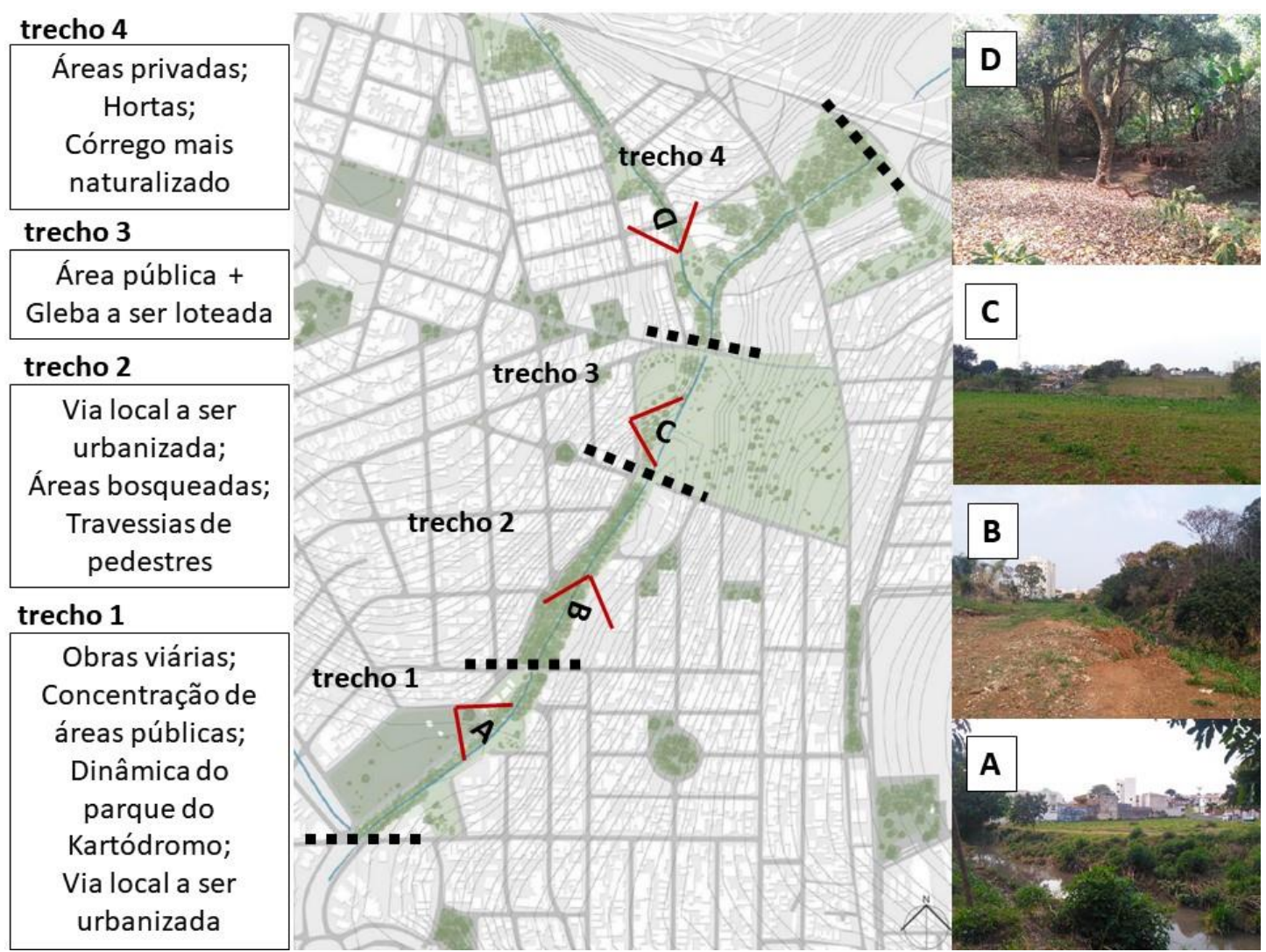

Figura 51: Cartografia quente (observações sobre os espaços, divididas por trechos, e vistas relevantes).

Fonte: GTPU, 2019 modificado pela autora.

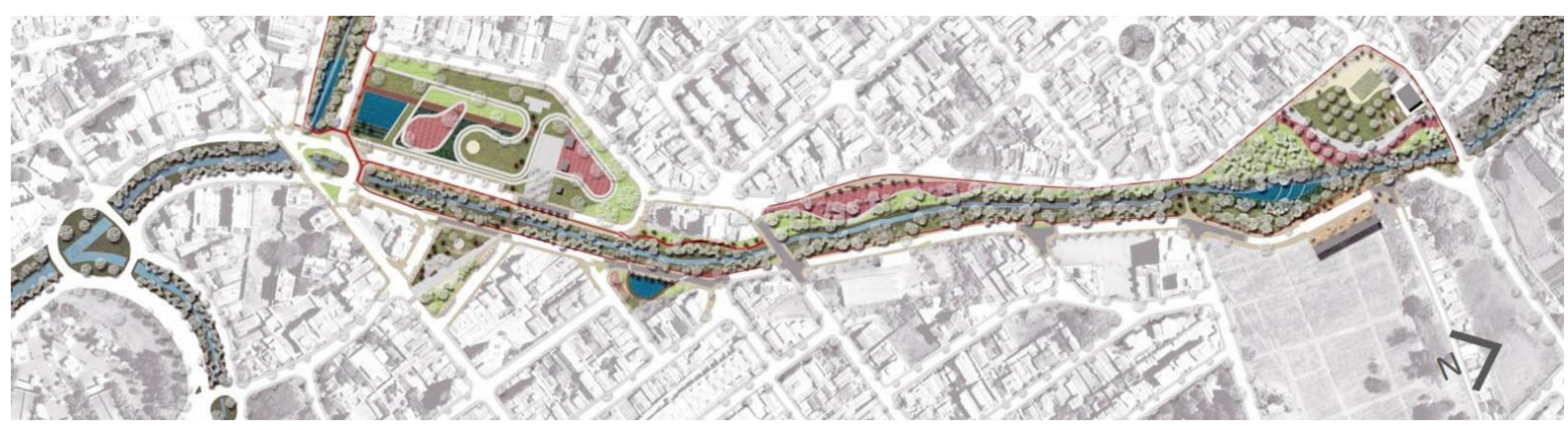

Figura 52: Planta baixa Projeto Orla do Monjolinho Fonte: GTPU, 2019. Desenho: Leandro Schenk. 


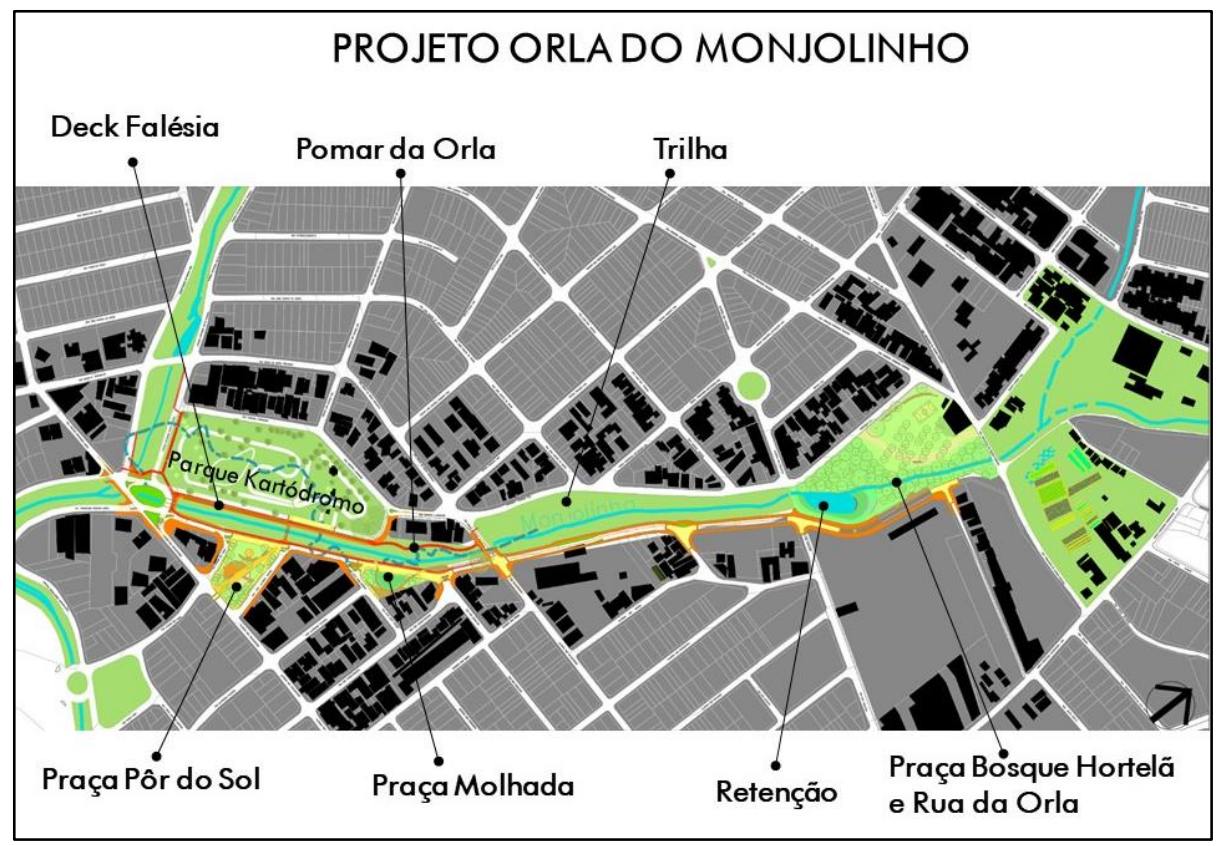

Figura 53: Planta baixa Projeto Orla do Monjolinho. Fonte: GTPU, 2019.

Os cenários representam por meio de imagens (perspectivas/ vistas) as espacialidades pretendidas pelo projeto (figuras 54), facilitando seu entendimento. Através dos cenários busca-se mostrar para o poder público as possibilidades de um desenvolvimento urbano em congruência com a natureza e criar na população o desejo por vivenciar tais espaços.

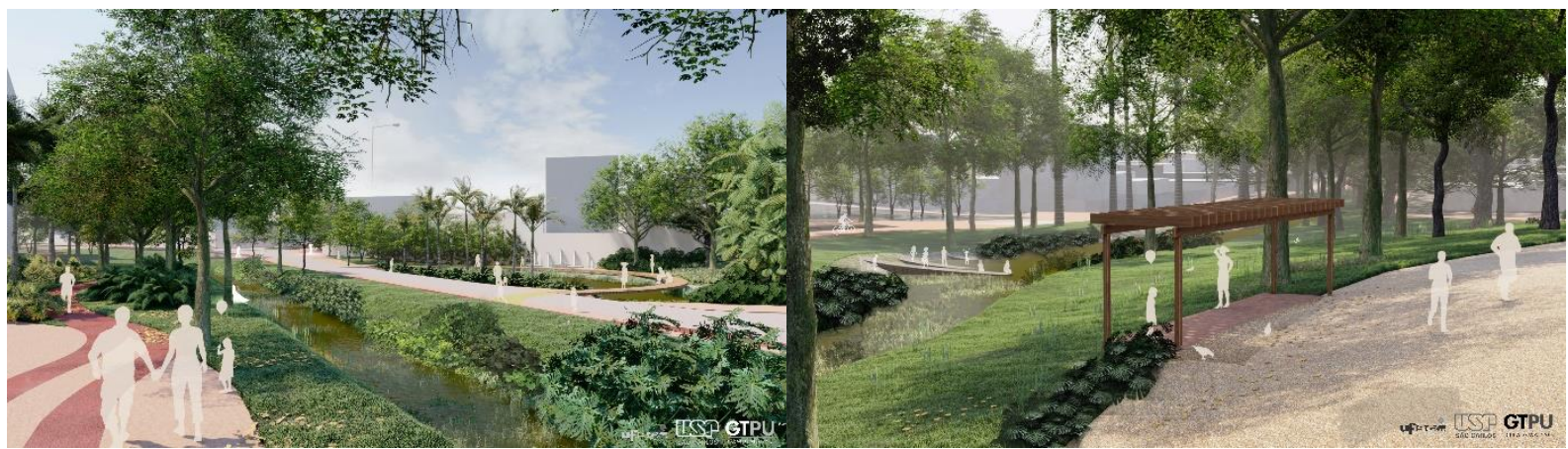

Figura 54: Perspectivas do Projeto Orla do Monjolinho.

Fonte: GTPU, 2019. Desenho: Luciana Schenk e Cauê Martins Silva. 


\section{CONSIDERAÇÕES FINAIS}

O Planejamento com a Paisagem pretende promover um desenvolvimento urbano mais harmônico, abrangendo elementos referentes às dimensões da paisagem que usualmente são desconsiderados pelo planejamento territorial tradicional. Retoma-se conceitos importantes sobre a paisagem e a trajetória de planejar com a paisagem a fim de encontrar bases para as análises, sistematização, e ações para a proposição do Sistema de Espaços Livres (SEL). Assim, é pertinente a definição de Santos (2003) em que a paisagem urbana é compreendida como produto e meio das relações entre o suporte físico e as intervenções antrópicas em um movimento contínuo, ou seja, como fisionomia resultante do uso e da ocupação do solo, tanto em relação a sua forma, quanto a sua distribuição e localização. Observa-se nesta definição a conexão e até mesmo a sobreposição das dimensões da paisagem conforme a descrito por Schlee et al. (2009): dimensão morfológica, dimensão funcional, dimensão histórica, dimensão simbólica, dimensão dinâmica. Considerar a paisagem no planejamento do território e conceber suas dimensões separadamente contraria o significado do termo, sendo estas dimensões intrínsecas a ele e, como sugeriu Besse (2014, p. 64):

[...] quem quer que se depare com a questão da paisagem está confrontado ao problema da coexistência de racionalidades paisagísticas diferentes, e ao da rearticulação das funções da razão que a modernidade dissociou.

Os precursores do Planejamento com a Paisagem captaram a relevância da presença dos espaços verdejados na cidade para um desenvolvimento urbano equilibrado, inicialmente sob o viés sanitário e estético e, em resposta aos males da cidade industrial, também vinculados à origem da disciplina Urbanística e com o desígnio de proporcionar qualidade de vida. Posteriormente, estruturando a expansão urbana e agregando avanços técnicos aos valores estéticos para criar espaços de sociabilidade, ideias elaboradas por Olmsted, que lançou as bases da Arquitetura da Paisagem. Quase um século depois, McHarg (2000) também explicitou a importância do desenvolvimento humano em harmonia com a natureza, indicando que o planejamento urbano deveria estar atento aos processos naturais e às dimensões sociais, culturais, históricas e cênicas da paisagem. Ele acreditava que as 
características intrínsecas da natureza determinavam oportunidades e limites às intervenções humanas e, através do método por ele desenvolvido seria capaz de indicar a aptidão do lugar para uma determinada atividade. O Planejamento Ecológico desenvolvido por McHarg compreendia os processos naturais como valores sociais, dado que esses processos são essenciais à sobrevivência humana. Desta forma, a urbanização deveria observar a aptidão do local visando a proteção dos processos naturais e da população. Ideias que influenciaram os trabalhos de seus seguidores, Michael Hough, Richard Forman e Anne Spirn. Na visão de Spirn (1995), a cidade participa da natureza, assim, concebê-las como entidades separadas resultou no agravamento dos problemas ambientais.

No Brasil, o contato com o campo da Arquitetura da Paisagem aconteceu por meio da temática ambiental. A natureza física e seus atributos foram incorporados ao planejamento urbano de distintas maneiras, inicialmente sob o viés estético, passando por considerações técnicas e, finalmente, sob orientação ambiental-ecológica. Durante muito tempo, os governantes acreditaram que a saída para os problemas relacionados à água - epidemias, poluição, enchentes, deslizamentos - seriam solucionados pelas obras de engenharia que consistem em drenagem de áreas úmidas, aterramento de mangues, canalização e tamponamento de rios, construção de galerias para águas pluviais. Este tipo de solução resultou em modificações profundas na fisionomia da paisagem, construindo um conflito com o ambiente natural e, em muitos casos trazendo graves danos à população e ao ambiente.

Os planos diretores tecnicistas que abrangiam diversos aspectos relacionados à cidade incluindo os aspectos do ambiente físico não consideravam os espaços livres como determinantes do planejamento urbano, nem consideravam questões estético-culturais e tampouco entendiam a paisagem como integradora de todas essas questões. Neles a temática ambiental foi apenas reconhecida como uma das políticas setoriais associadas às áreas de saneamento e meio ambiente, nas quais ocorria a identificação e proteção de "áreas verdes" e de preservação. Esta visão permaneceu nos planos diretores até recentemente e era constituída a partir dos campos de especialização, produzindo de olhares fragmentados sobre a cidade, inexistindo inclusive uma articulação com as outras políticas setoriais.

Concorda-se com Costa (2008) quando afirma que os descompassos entre planejamento ambiental e planejamento urbano evidenciou as distintas racionalidades que 
os originaram e os direcionaram em percursos temporais e políticos também distintos. Existiram tentativas de conciliação das temáticas dos dois lados através do estabelecimento de um corpo legal para guiar os planejamentos. A Lei Federal $n=6.766 / 1979$, sobre o Parcelamento do Solo e a Lei no 12.651/2012, conhecida como Código Florestal, apresentaram disposições com a finalidade de orientar o uso e a ocupação do solo de forma compatível com o ambiente natural. O Estatuto da Cidade, que estabeleceu as diretrizes gerais da política urbana, articulou o direito à cidade à compatibilização das ações humanas com o ambiente natural, visando a sustentabilidade do desenvolvimento urbano. Este regulamento trouxe uma série de instrumentos que podem auxiliar nesta compatibilização e que se refletiram na inclusão da pauta ambiental nos planos diretores, vinculada à proteção da vida humana e dos recursos naturais. São inegáveis os avanços promovidos por estes regulamentos, no entanto, permanece o desafio da tradução de diretrizes na forma urbana (MARTINS, 2012), bem como permanece a desarticulação dos planos diretores com as outras políticas setoriais como a habitacional, revelando grande dificuldade em romper com a lógica setorial (COSTA et al, 2011)

Em São Carlos, a construção do conflito entre desenvolvimento urbano e ambiente natural ocorreu principalmente pelo domínio técnico dos cursos d'água, que remonta à expansão do traçado reticular da malha urbana original da cidade sobre o vale, transpondo o córrego do Gregório em direção à estação ferroviária. A flexibilização da legislação urbanística, a ausência de regramentos claros, e a fiscalização deficiente sobre a implantação de parcelamentos permitiram o espraiamento da cidade através de loteamentos periféricos e em descontinuidade com a malha urbana preexistente, muitos deles com infraestrutura precária e ausência de espaços livres qualificados. Este processo foi caracterizado pela ação especulativa dos loteadores e pela segregação socioespacial.

A construção de novos eixos de circulação e o advento do transporte por ônibus e automóvel também se relacionam com a fragmentação do tecido urbano, pois permitiram que a população morasse afastada do Centro da cidade. Na década de 1970, a implantação de avenidas marginais aos córregos Gregório, Monjolinho e Tijuco Preto acompanhadas da canalização e em alguns casos do tamponamento dos cursos d'água, foi considerada uma solução adequada para a questão viária na época, o que posteriormente revelou-se bastante 
conflituosa. Os córregos eram vistos pela população como obstáculos a expansão urbana, locais desagradáveis devido ao mau cheiro e às inundações recorrentes na época das chuvas. Somente em 2000, houve a condenação da implantação de avenidas marginais nas APPs ao longo de seus cursos d'água sem licenciamento ambiental, o que resultou no Termo de Ajustamento de Conduta (TAC), que exigiu uma série de intervenções para mitigar os danos ambientais nestas áreas, entre outras medidas.

Nas décadas de 1980 e 1990, a expansão urbana continuou a ocorrer, reafirmando os padrões de produção do território dos anos anteriores. Ao Sul foram constituídos loteamentos populares nas proximidades do córrego Água Quente, avançando sobre áreas declivosas e solos arenosos. Na década de 2000 houve a expansão ao Norte, avançando sobre a área rural através da implantação de empreendimentos imobiliários de grande porte destinados a classes de maior poder aquisitivo, reforçando a segregação socioespacial.

A temática ambiental foi retomada no Plano Diretor Participativo (2005), expressa especialmente através da intenção de proteger os recursos hídricos e áreas de preservação ambiental, destacando-se a instituição de Áreas Especiais de Interesse Ambiental e de instrumentos que potencialmente poderiam contribuir para a proteção do meio ambiente natural, tais como o Estudo de Impacto de Vizinhança (EIV) e o Zoneamento Ambiental que, entretanto, não foram regulamentados. Foram colocadas diretrizes para orientar a expansão da cidade que definiram as direções Norte e Oeste como prioritárias, onde as características físico-ambientais são relativamente mais propícias para o desenvolvimento, se comparadas às características ambientais ao Sul da cidade. Como observou Peres (2012), o Plano não conseguiu frear a expansão e os processos especulativos ao Sul, área de grande fragilidade do ponto de vista socioambiental. Apesar disso, o Plano compreendeu o território a partir da sua geografia física, o que foi apontado positivamente por apresentar informações relevantes sobre as quais deveriam pautar-se as políticas públicas relacionadas ao Município (SCHENK, PERES, FANTIN, 2017).

A Lei das Áreas de Proteção e Recuperação dos Mananciais (APREM) aprovada em 2006 é uma normativa articulada ao Plano Diretor Participativo (2005), que repercutiu em diretrizes, zoneamentos, coeficientes e parâmetros construtivos diferenciados para o uso e a ocupação das áreas de mananciais da sub bacia hidrográfica do Córrego Monjolinho e parte 
da sub bacia do Ribeirão do Feijão. Esta Lei controlou a ocupação nestas áreas, porém, para uma aplicação mais efetiva, ainda é indispensável seu aperfeiçoamento quanto aos critérios para o licenciamento e aprovação de atividades (PERES, 2012).

O Plano Diretor de Drenagem Urbana Ambientalmente Sustentável do Município de São Carlos (2011) integrou o arcabouço normativo a respeito da temática ambiental. Esse Plano tinha a finalidade de subsidiar tecnicamente e institucionalmente a Prefeitura Municipal para reduzir os impactos das inundações e criar condições para uma gestão sustentável da drenagem urbana. Depois de uma pesquisa detalhada sobre as condições da rede hídrica da cidade foram propostas medidas estruturais, que compreendiam a construção de reservatórios de água e medidas não estruturais, que consistiam principalmente na capacitação de técnicos da Prefeitura Municipal para operacionalizar as ações previstas por este Plano Diretor, além de medidas compensatórias para o controle dos volumes adicionais de escoamento decorrentes da impermeabilização do solo. O Plano, que não foi executado, foi retomado em 2017 e estaria sendo atualizado ${ }^{144}$.

O processo de revisão do Plano Diretor teve uma proposta elaborada pelo Instituto de Arquitetura e Urbanismo da USP em 2011. Esta proposta buscou uma leitura transversal do município, relacionando dinâmicas socioespaciais e físico-territoriais, de tal forma que sua perspectiva se aproximou do campo do conhecimento que norteia o planejamento com a paisagem. Nesta perspectiva, adotou-se o instrumento de Zoneamento Ambiental para orientar e direcionar a expansão urbana, evitando-se as áreas ambientalmente frágeis. A bacia hidrográfica foi compreendida como unidade de planejamento e gestão, utilizada na delimitação do macrozoneamento municipal. O documento definiu ainda alguns Projetos Estratégicos, articulando e qualificando espaços livres do sistema de lazer e integrando-os às áreas de preservação ambiental. Esse plano foi descartado e uma nova revisão foi iniciada em 2012. Depois de uma série de conflitos e negociações entre, de um lado o mercado imobiliário e os grandes proprietários de terra e, do outro, as Universidades e as Organizações não Governamentais (ONGs) relacionadas ao meio ambiente, o Plano Diretor Estratégico (2016) foi aprovado.

\footnotetext{
${ }^{144}$ De acordo com a notícia na homepage da Prefeitura Municipal de São Carlos. Disponível em: $<$ http://www.saocarlos.sp.gov.br/index.php/noticias-2017/170967-placas-alertam-para-o-risco-dealagamentos.html>. Acesso em: 19 nov. 2019.
} 
Este Plano (2016) ampliou significativamente as Áreas de Interesse Ambiental da cidade pela inclusão de quase a totalidade das margens dos córregos internos ao perímetro urbano e da Zona de Expansão Urbana, das áreas públicas de Sistema de Lazer, dos canteiros centrais e parques lineares, das SAPREs 1 e 2 , dos maciços de vegetação nativa demarcados e das APPs e das Faixas Verdes Complementares junto alguns corpos d'água. Além da proteção e da recuperação, o Plano apontou a relevância destas áreas para a adequada drenagem de água pluvial, bem como a sua destinação para a criação de Parques Lineares e Unidades de Conservação. Embora muitas destas áreas encontrem-se ocupadas, a sua gravação na legislação representa um passo importante na direção de um potencial Sistema de Espaços Livres, objeto desta pesquisa. Os princípios e objetivos deste Plano vinculam-se aos ideais de um meio ambiente ecologicamente equilibrado, através de usos do solo compatíveis com a preservação ambiental. No entanto, o que se observa é o aumento expressivo do perímetro urbano, que avança sobre áreas ao Sul da cidade, local caracterizado pela fragilidade ambiental, fato que, pela ótica dos agentes do mercado imobiliário seria solucionado tecnicamente, revelando que os problemas urbanos ambientais em São Carlos resultam de escolhas de planejamento sob o discurso de interesses e oportunidades (SCHENK, PERES, FANTIN, 2016).

Em 2017, a Prefeitura aprovou o Decreto no 170/2017 que criou os parques urbanos de proteção, lazer e educação ambiental no município de São Carlos, considerando os benefícios para a população referentes à qualidade de vida, propiciados pelo contato e presença da vegetação em ambientes urbanos. O Decreto proporcionou a proteção legal destas áreas, não havendo a preocupação de estabelecer um Sistema de Espaços Livres. 0 Grupo de Trabalho e de Planejamento dos Parques Urbanos (GTPU) foi criado pelo Conselho Municipal de Defesa do Meio Ambiente de São Carlos (CONDEMA) para promover o planejamento destes parques. O GTPU, grupo da qual a autora participa, adicionou o objetivo de desenvolver uma proposta de SEL, articulando esses espaços e ampliando suas potencialidades, proposta que veio ao encontro desta dissertação.

A estratégia metodológica para Planejar com a Paisagem apresentada nesta dissertação vem sendo aplicada na disciplina de Paisagismo do curso de Arquitetura e Urbanismo do Instituto de Arquitetura e Urbanismo da USP-São Carlos e aprofundada pelo 
GTPU. Esta estratégia metodológica tem por base o campo disciplinar da Arquitetura da Paisagem e caracteriza-se: pela complexidade, intrinsicamente ligada à polissemia da Paisagem; pela transversalidade, entre os campos de conhecimento e entre os agentes na produção do espaço urbano; pelo cruzamento de informações de diferentes naturezas; e pelo trânsito de escalas, das cartografias gerais ao fenômeno (experiência do pedestre).

A leitura da paisagem da cidade de São Carlos e seus espaços livres foi realizada por meio de cartografias, algumas existentes e outras confeccionadas nesta pesquisa, que cruzam informações de diferentes naturezas, e contemplam as características físicas da paisagem, as legislações, os conflitos, as presenças e as dinâmicas da cidade. Estas cartografias foram analisadas com a intenção de revelar potencialidades e limitações destes espaços para a proposição do SEL para a cidade. Para tanto, utilizou-se a tecnologia do Sistema de Informações Geográficas (SIG), que auxiliou o processo de manipulação das informações. A leitura da paisagem e de seus espaços livres foi realizada a partir do recorte das microbacias hidrográficas urbanas, de forma a abranger a Macrozona Urbana e suas adjacências, visando orientar da expansão urbana, e tendo em vista que grande parte dos problemas urbanos ambientais em São Carlos é decorrente do conflito com a rede hídrica. A partir desta análise e, tendo em vista esse conflito, a cartografia de Áreas de Especial Interesse Ambiental do Plano Diretor Estratégico (2016) foi a base sobre qual realizou-se ponderações acerca da proposição do Sistema de Espaços Livres.

Os espaços livres foram classificados em categorias, visando agrupar elementos afins para organizar o SEL e, deste modo, promover a elaboração de regulamentos, planos e programas adequados para cada conjunto de espaços com a intenção de efetivação da proposta. As categorias foram fundamentadas no campo disciplinar da Arquitetura da Paisagem, nas categorias existentes na literatura levantada, na legislação, bem como nas especificidades da cidade de São Carlos. A classificação apresentada estabelece uma hierarquia, graus de ocupação e utilização dos espaços do menos ao mais antropizado, almejando a lógica da dupla proteção, isto é, a proteção do ambiente natural e do ser humano, vinculadas às legislações ambientais e urbanas e recuperando os valores evidenciados por McHarg. 
Como resultado deste processo, os espaços livres foram organizados em Parques de Conservação, Parques Lineares, Parques Urbanos e Praças com o objetivo de proporcionar espaços de sociabilidade e lazer, promover conectividade e mobilidade alternativa e agradável associadas à estes espaços de fruição, e configurar um cinturão verde para direcionar o crescimento urbano e estimular a ocupação de glebas desocupadas na malha urbana consolidada.

O Sistema de Espaços Livres proposto encontra-se no âmbito do planejamento e visa orientar a expansão urbana para locais adequados, modificando o caráter residual atribuído aos espaços livres (TARDIN, 2008), decorrente do modelo de planejamento urbano hegemônico. Neste sentido, pretende-se contribuir para a modificação deste modelo de planejamento ao estabelecer uma cartografia complexa que corresponda à análise de diferentes tipos de dados dispersos, gerando informações novas sobre a paisagem em tela, que auxiliem planejadores e poder público na formulação de políticas públicas e projetos dos parques.

O Sistema de Espaços Livres proposto configura passos metodológicos que se iniciam com a conquista da área de projeto e que se traduzem em dois movimentos: a coleção de informações acerca do lugar, cartografias e documentos em geral, e a confrontação das cartografias com a realidade através da experiência do pedestre na escala do fenômeno (local). As visitas a campo têm como recorte territorial uma microbacia hidrográfica, na qual se planeja um percurso, um roteiro predeterminado indicando-se pontos de interesse a serem explorados, que podem ser modificados de acordo novas percepções proporcionadas pelo contato com o lugar. Os novos dados obtidos em campo compõem a denominada cartografia "quente", em distinção à chamada cartografia "fria" referente ao SEL na escala documental da etapa anterior.

A partir das ponderações feitas sobre as informações contidas nestas cartografias são formuladas as diretrizes para orientar o projeto do parque e propor cenários almejados. Estes cenários (imagens) tem o objetivo de facilitar a compreensão do projeto, tornando-o mais acessível aos governantes e à população em geral e, ao mesmo tempo, em que desperta na população o desejo por vivenciar tais espaços. Por meio do desenho dos parques cogita-se promover o contato entre pessoas e natureza, aproximando-as dos processos naturais e 
incentivando a mudança do padrão de percepção do ambiente natural (HOUGH, 1998), assegurando desta forma que estes lugares sejam protegidos.

A complexidade inerente ao tema Paisagem e sua definição por diferentes áreas do conhecimento indicam que o Planejamento com a Paisagem seja realizado por uma equipe multidisciplinar, de forma a contornar imprecisões da análise e aprofundar a investigação acerca dos espaços livres e, abranger outros aspectos da paisagem.

Os espaços livres de um território, ou seja, aqueles sem a presença de edificações, verdejados ou não (MAGNOLI, 1982), podem assumir um papel significativo na minimização dos problemas urbanos decorrentes do planejamento efetivado até então. Tais espaços desempenham múltiplas funções, desde aquelas relacionadas à infraestrutura urbana até aquelas relacionadas ao conforto térmico, à conservação e proteção de ecossistemas, bem como aquelas referentes à sociabilidade e a experiência cultural e estética. Estas funções são pouco exploradas ao se ponderar seus benefícios, em especial se associados entre si, sistemicamente, através de um desenho urbano ambiental. Deste modo, estes espaços são relevantes no ordenamento da expansão urbana e podem ser entendidos como oportunidades para estruturar a malha urbana de forma favorável ao meio físico e aos interesses socioeconômicos, prevendo-se os usos mais adequados para cada espaço. O SEL busca estratégias para articular os fragmentos de espaços livres em diversas escalas e com diversas funcionalidades, qualificações estéticas e fundiárias (QUEIROGA, 2011). Estes espaços estabelecem, ainda que potencialmente, relações entre si e, mesmo sem conexão física, afetam-se reciprocamente. O desenvolvimento de metodologias que reconheçam e analisem os espaços livres como estruturadores do espaço urbano, se inserem no planejamento com a paisagem. 


\section{REFERÊNCIAS BIBLIOGRÁFICAS}

ABERCROMBIE, Patrick. Greater London Plan 1944. Londres: His Majesty's Stationery Office, 1945.

ACKEL; Luiz; CAMPOS, Candido Malta. Freire e Bouvard: a cidade europeia. In A cidade não pode parar: planos urbanísticos de São Paulo no século XX. São Paulo: Mackpesquisa, 2002. p. 13-53.

AGÊNCIA NACIONAL DE ÁGUAS (ANA). Planejamento dos recursos hídricos. Homepage. Disponível em: <https://www.ana.gov.br/gestao-da-agua/planejamento-dos-recursoshidricos>. Acesso em: 15 de jan. de 2020.

ANDRADE, Carlos Roberto Monteiro de. O Plano de Saturnino de Brito para Santos e a Construção da Cidade Moderna no Brasil. In: IV Encontro Nacional da ANPUR, Salvador. Anais. Salvador, 1991, p. 565-573.

ANDRADE, Carlos Roberto Monteiro de. A Peste e o Plano: o urbanismo sanitarista do Eng. Saturnino de Brito. Dissertação (mestrado em Estruturas Ambientais Urbanas) Faculdade de Arquitetura e Urbanismo, USP, São Paulo. 1992a.

ANDRADE, Carlos Roberto Monteiro de. De Viena a Santos: Camillo Sitte e Saturnino de Brito. In SITTE, Camillo. A Construção das Cidades Segundo Seus Princípios Artísticos. São Paulo: Ática, 1992b. p. 206-234.

ANELLI, Renato Luiz Sobral. Sistema Viário e Recuperação de Recursos Hídricos (córregos e nascentes) em São Carlos/SP. In: Revista Tópos. v. 1, n. 1, 2007.

ARAÚJO, Suely Mara Vaz Guimarães de. O Estatuto da Cidade e a Questão Ambiental. Consultoria Legislativa na Área XI da Câmara dos Deputados. Abril. Brasília, DF: Câmara dos Deputados, 2003. p. 1-12.

BARTALINI, V. Áreas verdes e espaços livres urbanos. Revista Paisagem Ambiente: ensaios, $n$. 1-2, p. 49-54, 1986.

BASSUL, José Roberto. Reforma urbana e Estatuto da Cidade. EURE, vol. XXVIII, no 84, 2, 2002.

BENEVOLO, Leonardo. História da Arquitetura Moderna. 3ạ edição - São Paulo: Editora Perspectiva, 2001.

BENEVOLO, Leonardo. História da Cidade. São Paulo: Editora Perspectiva, 2012. 
BESSE, Jean-Marc. As cinco portas da paisagem - ensaio de uma cartografia das problemáticas paisagísticas contemporâneas. In: O gosto do mundo: exercícios de paisagem. Rio de Janeiro: Eduerj: 2014.

BIRKHOLZ, Lauro Bastos. Planos Diretores Municipais no Estado de São Paulo e sua Implantação. Tese de Concurso para Livre Docência junto a Cátedra de Planejamento II (1a e 2- partes) da Faculdade de Arquitetura e Urbanismo, Universidade de São Paulo, São Paulo, 1964.

BONDUKI, Nabil G. Os pioneiros da habitação social no Brasil. Cem anos de política pública no Brasil. São Paulo: UNESP/ SESC SENAC. Vol. 1, p. 1- 135, 2014.

CAVALHEIRO et al. Proposição de Terminologia para o Verde Urbano. Boletim Informativo da Sociedade Brasileira de Arborização Urbana. Rio de Janeiro, ano VII, n. 3, p. 7, jul/ago/set 1999.

CHIQUITO, Elisângela de Almeida. A Comissão Interestadual da Bacia Paraná-Uruguai: do planejamento de vale aos polos de desenvolvimento. Tese de doutorado. Programa de PósGraduação em Arquitetura e Urbanismo do Instituto de Arquitetura e Urbanismo da Universidade de São Paulo. São Carlos, 2011.

COHEN, J.L. L'extension de Paris. In: LECLERC, Bénédicte (dir.). Jean Claude Nicolas Forestier 1861-1930: Du jardin au paysage urbain. Actes du Colloque international sur J. C. N. Forestier. Paris: Picard, 1990

COMPANHIA DE GESTÃO DOS RECURSOS HÍDRICOS (COGERH). Planos de Bacias. Homepage. Disponível em: <https://portal.cogerh.com.br/planos-de-bacias/>. Consultado em: 15 jan. 2020.

COSTA, Heloisa Soares de Moura. A trajetória ambiental no planejamento urbano no Brasil. In: COSTA, Geraldo Magela; MENDONÇA, Jupira Gomes de (org.). Planejamento Urbano no Brasil: trajetória, avanços e perspectivas. Belo Horizonte: C/Arte, 2008. p. 80-92.

COSTA, Heloisa Soares de Moura; CAMPANTE, Ana Lúcia Goyatá; ARAÚJO, Rogério Palhares Zschaber de. A Dimensão Ambiental nos Planos Diretores de Municípios Brasileiros: um olhar panorâmico sobre a experiência recente. In: JUNIOR, Orlando Alves dos Santos; MONTANDON, Daniel Todtmann (orgs.). Os Planos Diretores Municipais Pós-Estatuto da Cidade: balanço crítico e perspectivas. Rio de Janeiro: Letra Capital/Observatório das Metrópoles: IPPUR/UFRJ, 2011. p. 173-217.

DEVESCOVI, Regina de C. Baliero. Urbanização e acumulação: um estudo sobre a cidade de São Carlos. Dissertação (Mestrado). São Paulo: FGV, 1985. 261 p.

DONOSO, Verônica Garcia. A paisagem e os sistemas de espaços livres na urbanização contemporânea do interior paulista: estudo de caso da área entre São Carlos, Araraquara e Ribeirão Preto. Dissertação (Mestrado) FAUUSP. São Paulo: 2011. 
FARIA, T. J. P. Os projetos e obras do engenheiro Saturnino de Brito e mudança na paisagem urbana. Revista Geografia Ensino \& Pesquisa, v. 19, n. especial, p. 115-122, 2015.

FAUSTINO, Alexandre, da S.; TÃO, Nícolas, G. R.; SCHENK, Luciana, B. M.; PERES, Renata, B.; FANTIN, Marcel. Análise de Potencialidades dos Espaços Livres de São Carlos (SP) na Composição de um Sistema. In: XI Colóquio QUAPA SEL - Quadro do Paisagismo no Brasil Salvador - Bahia - UFBA, 2016. Anais... Salvador: XI QUAPA SEL, 2016.

FEITOSA, Jardel Pontes. Industrialização e urbanização em São Carlos nas décadas de 1930 a 1960. Dissertação (Mestrado). Programa de Pós-Graduação em Arquitetura e Urbanismo do Instituto de Arquitetura e Urbanismo da Universidade de São Paulo. São Carlos, 2015.

FELDMAN, Sarah. Avanços e limites na historiografia da legislação urbanística no Brasil. Revista Brasileira de Estudos Urbanos e Regionais, n. 4, maio, ANPUR, 2001, p. 33-46.

FELDMAN, Sarah. Planejamento e Zoneamento. São Paulo: 1947-1972. São Paulo: Ed. da Universidade de São Paulo/ Fapesp, 2005.

FERNANDES, Edésio. Estatuto da Cidade, Mais de 10 Anos depois: razão de descrença, ou razão de otimismo? Rev. UFMG, Belo Horizonte, v. 20, n. 1, p. 212-233, jan./ jun. 2013.

FONTES, Nádia. Proposta metodológica para planejamento de sistemas de espaços livres: Ribeirão Preto - SP. Tese (Doutorado em Arquitetura e Urbanismo) - Universidade Estadual Paulista, Rio Claro - SP, 2009.

FORESTIER, Jean Claude Nicolas. Grandes Villes et systèmes de parcs: suivi de deux mémoires sur les villes impériales du Maroc et sur Buenos Aires. Paris: Norma Ed, 1997.

FORMAN, Richard T. T. Land Mosaics - The ecology of landscape and regions. Reino Unido: Cambridge University Press, 1995.

GRAVAGNUOLO, B. Historia del urbanismo en Europa, 1750-1960. Madri: Akal, 1998.

HERZOG, Cecília Polacow. Cidade para todos: (re) aprendendo a conviver com a natureza. Rio de Janeiro: Mauad X: Inverde, 2013.

HOUGH, Michael. Naturaleza y ciudad. Barcelona: GG, 1998.

HOWARD, E. Cidades-jardins de amanhã. São Paulo: HUCITEC, 1996.

INSTITUTO BRASILEIRO DE GEOGRAFIA E ESTATÍ́STICA (IBGE). Censo Demográfico, 2010.

INSTITUTO BRASILEIRO DE GEOGRAFIA E ESTATÍSTICA (IBGE). Brasil em Síntese, 2019. Disponível em: <https://cidades.ibge.gov.br/brasil/sp/sao-carlos/panorama>. Acesso: em: 29 nov. de 2019.

JACOBS, Jane. Morte e vida de grandes cidades. São Paulo: Martins Fontes, 2000. 
LECLERC, Bénédicte (dir.). Jean Claude Nicolas Forestier 1861-1930: Du jardin au paysage urbain. Actes du Colloque international sur J. C. N. Forestier, Paris: Picard, 1990.

LECLERC, B.; TARRAGÒ CID, S. Le texte théorique foundateur. In: Grandes Villes et systèmes de parcs: suivi de deux mémoires sur les villes impériales du Maroc et sur Buenos Aires. Paris: Norma Ed, 1997.

LEME, Maria Cristina da Silva (org.). Urbanismo no Brasil: 1895-1965. São Paulo. FUPAM/ Studio Nobel, 1999.

LEONELLI, Gisela Cunha Viana. A construção da lei federal de parcelamento do solo Urbano 6.766: debates e propostas do início do sec. XX a 1979. Tese (Doutorado). Programa de PósGraduação em Arquitetura, Escola de Engenharia de São Carlos da Universidade de São Paulo. São Carlos, 2010.

LIMA, Maria Cecília Pedro Bom de. Paisagem, Cartografia e Projeto: uma leitura da bacia hidrográfica do córrego Monjolinho em São Carlos, SP. Dissertação (Mestrado). Programa de Pós-Graduação em Arquitetura e Urbanismo do Instituto de Arquitetura e Urbanismo da Universidade de São Paulo. USP, 2019.

LIMA, Renata Priore. O processo e o (des)controle da expansão urbana em São Carlos (18571977). Dissertação (Mestrado). Escola de Engenharia de São Carlos da Universidade de São Paulo. São Carlos, 2007.

LUCCHESE, Maria Cecilia. O planejamento urbano de Londres (1943 - 1947). In: Risco revista de pesquisa em arquitetura e urbanismo programa de pós-graduação do instituto de arquitetura e urbanismo IAU-USP, 2012. p. 67-81.

MACEDO, Silvio Soares. Espaços Livres. Revista Paisagem Ambiente: ensaios, n. 7, p. 15-56, jun. 1995.

MAGNOLI, Miranda Maria Esmeralda Martinelli. Espaços livres e urbanização: Uma introdução a aspectos da paisagem metropolitana. Tese (Livre-docência) - FAUUSP. São Paulo, 1982.

MAGNOLI, Miranda Martinelli. Espaço Livre - Objeto de Trabalho. Revista Paisagem Ambiente: ensaios, n. 21, São Paulo, p. 175-198, 2006a.

MAGNOLI, Miranda Martinelli. O Parque no Desenho Urbano. Revista Paisagem Ambiente: ensaios, n. 21, São Paulo, p. 199-214, 2006b.

MARTINELLI, Marcello. Cartografia ambiental: uma cartografia diferente? In: Revista Do Departamento de Geografia, Universidade de São Paulo, 2011. v. 7, p. 61-80.

MARTINS, Maria Lucia Refinetti. Sociedade e natureza no meio ambiente urbano. In: RIBEIRO, Ana Clara Torres, LIMONAD, Ester, GUSMÃO, Paulo Pereira de (orgs.). Desafios ao 
planejamento: produção da metrópole e questões ambientais. Rio de Janeiro: Letra Capital: ANPUR, 2012. p. 154-170.

MARICATO, Ermínia. Na periferia do mundo globalizado: metrópoles brasileiras. São Paulo em perspectiva, 14 (4) 2000, p. 21-33.

MCHARG, Ian. Proyectar con Ia naturaleza. Barcelona: Editorial G. Gili 2000. Traduzido da edição de 1992.

MEDEIROS, Anderson. Workshop Geoprocessamento Software Livre, Material de Apoio ao Curso. ClickGeo: Cursos de Geotecnologias, 2017.

MONTE-MÓR, Roberto Luís de Melo. Do urbanismo à política urbana: notas sobre a experiência brasileira. In: COSTA, Geraldo Magela; MENDONÇA Jupira Gomes de (org.), Planejamento Urbano no Brasil: trajetória, avanços e perspectivas. Belo Horizonte: C/Arte, $p$. 31-65, 2008.

MUMFORD, Lewis. Introdução de Lewis Mumford para a primeira edição. In: MCHARG, lan. Proyectar con la naturaleza. Barcelona: Editorial G. Gili 2000. Traduzido da edição de 1992.

MUMFORD, Lewis. A cidade na história: suas origens, transformações e perspectivas; tradução Neil R. da Silva. São Paulo: Martins Fontes, 1998.

ORGANIZAÇÃO DAS NAÇÕES UNIDAS (ONU). Nações Unidas Brasil: A ONU e o meio ambiente. Homepage. Disponível em: <https://nacoesunidas.org/acao/meio-ambiente/>. Acesso em: 27 de nov. de 2019.

OTTONI, Dacio A. B. In: HOWARD, E. Cidades-jardins de amanhã. São Paulo: HUCITEC, 1996.

PERES, Renata Bovo. O Planejamento Regional e Urbano e a Questão Ambiental: Análise da relação entre o Plano de Bacia Hidrográfica Tietê-Jacaré e os Planos Diretores Municipais de Araraquara e São Carlos, SP. Tese doutorado. Programa de Pós-Graduação em Engenharia Urbana, Universidade Federal de São Carlos, 2012.

PIRES, José Salatiel Rodrigues; SANTOS, José Eduardo dos; DEL PRETTE, Marcos Estevan. A Utilização do Conceito de Bacia Hidrográfica para a Conservação dos Recursos Naturais. In: SCHIAVETTI, Alexandre; CAMARGO, Antonio F. M. (editores). Conceitos de bacias hidrográficas: teorias e aplicações. Ilheus, BA: Editus, 2002. p. 17-35.

PORTO, Monica; PORTO, Rubem. Gestão de bacias hidrográficas. Estudos avançados. vol. 22 n. 63. São Paulo. p. 43-60, 2008.

QUEIROGA, Eugênio Fernandes. Sistemas de espaços livres e esfera pública em metrópoles brasileiras. In: Artigos \& Ensaios. RESGATE - vol. XIX, NO 21 - jan./jun. 2011.

REZENDE, Vera F. Evolução da produção urbanística na cidade do Rio de Janeiro, 1900-19501965. In: Urbanismo no Brasil: 1895-1965. São Paulo. FUPAM/ Studio Nobel, 1999. p.39-70. 
SANTOS, Emmanuel Antônio dos. Porque planejar com a paisagem. Revista do Programa de Pós-Graduação em Arquitetura e Urbanismo da FAUUSP. São Paulo, 2003. p. 100-123.

SCHENK, Luciana Bongiovanni Martins. Arquitetura da paisagem: entre o Pinturesco, Olmsted e o Moderno. 2008. 162 f. Tese (Doutorado em Arquitetura e Urbanismo) Departamento de Arquitetura e Urbanismo, Escola de Engenharia de São Carlos, Universidade de São Paulo, São Carlos, 2008.

SCHENK, Luciana B. M. e PERES, Renata B. Agentes produtores e espaços livres na forma urbana de São Carlos, SP. In: IX Colóquio QUAPÁ-SEL, 2014 Anais... Vitória: UFES, 2014, 16 p.

SCHENK, Luciana B. M.; PERES, Renata. B.; FANTIN, Marcel. A Revisão do Plano Diretor da Cidade de São Carlos e as Novas Formas Urbanas em Curso. In: X Colóquio QUAPÁ - SEL, Forma Urbana Contemporânea Brasileira: Espaços Livres, Produção e Apropriação, 2015, Brasília. Anais... Brasília: X QUAPA-SEL, 2015, v.1. p.1-19.

SCHENK, Luciana B. M.; PERES, Renata. B.; FANTIN, Marcel. Agentes Produtores e Forma Urbana: a Trajetória do Núcleo Gestor Compartilhado no Processo de Revisão do PDMSC. In: XI Colóquio QUAPA SEL - Quadro do Paisagismo no Brasil Salvador - Bahia - UFBA, 2016. Anais... Salvador: XI QUAPA SEL, 2016.

SCHENK, Luciana B. M.; PERES, Renata. B.; FANTIN, Marcel. Sistema de Espaços Livres e sua Relação com os Agentes Públicos e Privados na Produção da Forma Urbana de São Carlos, SP. In: XII Colóquio QUAPÁ - SEL, Rumos da Rede Nacional de Pesquisa QUAPÁ-SEL: consolidações e proposições, 2017, São Paulo. Anais... São Paulo: XII QUAPA-SEL, 2017, v.1. p. 53-92.

SCHLEE, M. et al. Sistema de Espaços Livres nas Cidades Brasileiras - Um Debate conceitual. In: Paisagem Ambiente: ensaios - n. 26 - São Paulo - p. 225 - 247 - 2009.

SCHVARSBERG, Benny. Planejamento Urbano no Brasil pós-1988: panorama histórico e desafios contemporâneos. In: FARIA, Rodrigo; SCHVARSBERG, Benny (org.). Políticas urbanas e regionais no Brasil. Brasília: Universidade de Brasília, Faculdade de Arquitetura e Urbanismo, 2011. p. 16-32.

SILVA, J. et al. Critérios para intervenções e transformações do sistema de espaços livres: uma reflexão conceitual e metodológica. In: Paisagem Ambiente: ensaios - n. 33 - São Paulo - p. 9 $-28-2014$.

SPIRN, Anne Whiston. $\mathbf{O}$ jardim de Granito: A natureza no desenho da cidade. Tradução de Paulo Renato Mesquita Pellegrino. São Paulo: Editora da Universidade de São Paulo, 1995.

SOMEKH, Nadia; CAMPOS, Candido Malta (org.). A cidade não pode parar: planos urbanísticos de São Paulo no século XX. São Paulo: Mackpesquisa, 2002.

TARDIN, Raquel. Espaços Livres: Sistema e Projeto Territorial. Rio de Janeiro: 7Letras, 2008. 
TRAVASSOS, L.; SCHULT, S. Recuperação socioambiental de fundos de vale urbanos na cidade de São Paulo, entre transformações e permanências. Cad. Metrop., São Paulo, v. 15, n. 29, jan/jun, 2013. p. 289-309.

VILLAÇA, Flávio. Uma contribuição para a história do planejamento urbano no Brasil. In: DEÁK, Csaba; SCHIFFER, Sueli Ramos (Org.). O processo de urbanização no Brasil. 1ed. São Paulo: Editora da Universidade de São Paulo, 1999. p. 169-243.

WALKER, Peter; SIMO, Melanie. Invisible Gardens: the search for modernism in American Landscape. Cambridge, Masschusetts: MIT Press, 1994.

WHATELY, Marussia et al (org.). Parques urbanos municipais de São Paulo: subsídios para a gestão. São Paulo: Instituto Socioambiental, 2008.

WMO. The Dublin Statement and Report of the Conference. International Conference on Water and the Environment: Development Issues for the 21st Century. 26-31 January 1992. Dublin, Ireland, 1992.

\section{Legislação e Fontes Documentais}

BRASIL. Lei no 6.766, de 19 de dezembro de 1979. Dispõe sobre o Parcelamento do Solo Urbano e dá outras Providências. Brasília, DF, 1979.

BRASIL. Lei no 6.938, de 31 de agosto de 1981. Dispõe sobre a Política Nacional do Meio Ambiente, seus fins e mecanismos de formulação e aplicação, e dá outras providências. Brasília, DF, 1981.

BRASIL. Constituição (1988). Constituição da República Federativa do Brasil. Brasília, DF, 1988.

BRASIL. Lei no 9.433, de 8 de janeiro de 1997. Institui a Política Nacional de Recursos Hídricos, cria o Sistema Nacional de Gerenciamento de Recursos Hídricos, regulamenta o inciso XIX do art. 21 da Constituição Federal, e altera o art. 1ㅇ da Lei no 8.001, de 13 de março de 1990, que modificou a Lei no 7.990, de 28 de dezembro de 1989. Brasília, DF, 1997.

BRASIL. Lei no 9.985, de 18 de julho de 2000. Regulamenta o art. 225, § 10, incisos I, II, III e VII da Constituição Federal, institui o Sistema Nacional de Unidades de Conservação da Natureza e dá outras providências. Ministério do Meio Ambiente. Brasília, DF, 2000.

BRASIL. Lei $\mathbf{n}^{\circ} \mathbf{1 0 . 2 5 7}$, de 10 de julho de 2001. Estatuto da Cidade. Regulamenta os arts. 182 e 183 da Constituição Federal, estabelece diretrizes gerais da política urbana e dá outras providências.

BRASIL. Medida Provisória no 2.220 de 4 de setembro de 2001. Dispõe sobre a concessão de uso especial de que trata o $\S 1$ o do art. 183 da Constituição, cria o Conselho Nacional de Desenvolvimento Urbano - CNDU e dá outras providências. 
BRASIL. Sistema Nacional de Cadastro Ambiental (SiCAR). Mapa de Reserva Legal do Município de São Carlos, 2018. Arquivo Shapefile.

BRASIL. Lei no $\mathbf{1 2 . 6 0 8}$ de 10 abril de 2012. Institui a Política Nacional de Proteção e Defesa Civil - PNPDEC; dispõe sobre o Sistema Nacional de Proteção e Defesa Civil - SINPDEC e o Conselho Nacional de Proteção e Defesa Civil - CONPDEC; autoriza a criação de sistema de informações e monitoramento de desastres; altera as Leis no 12.340, de 10 de dezembro de 2010, 10.257, de 10 de julho de 2001, 6.766, de 19 de dezembro de 1979, 8.239, de 4 de outubro de 1991, e 9.394, de 20 de dezembro de 1996; e dá outras providências. Brasília, DF, 2012.

BRASIL. Lei no 12.651 de 25 de maio de 2012. Dispõe sobre a proteção da vegetação nativa; altera as Leis no 6.938, de 31 de agosto de 1981, 9.393, de 19 de dezembro de 1996, e 11.428, de 22 de dezembro de 2006; revoga as Leis $n=4.771$, de 15 de setembro de 1965, e 7.754, de 14 de abril de 1989, e a Medida Provisória no 2.166-67, de 24 de agosto de 2001; e dá outras providências. Brasília, DF, 2012.

CONSELHO NACIONAL DE RECURSOS HÍDRICOS (CNRH). Resolução no 17, de 29 de maio de 2001. Estabelece diretrizes complementares para a elaboração dos Planos de Recursos Hídricos das Bacias Hidrográficas. Conselho Nacional de Recursos Hídricos. Brasília, DF: Ministério do Meio Ambiente, 2001.

CNUMAD. Conferência das Nações Unidas sobre o Meio Ambiente e Desenvolvimento. De acordo com a Resolução n. 44/228 da Assembleia Geral da ONU, de 22-12-89, estabelece uma abordagem equilibrada e integrada das questões relativas a meio ambiente e desenvolvimento: a Agenda 21 - Brasília: Câmara dos Deputados, Coordenação de Publicações, 1995.

FPM/PMSC. Fundação Pró-memória/ Prefeitura Municipal de São Carlos. Mapa da Poligonal Histórica e Imóveis Protegidos. 2017. Arquivo Shapefile.

FPM/PMSC. Fundação Pró-Memória/Prefeitura Municipal de São Carlos. Fotos de situações urbanas da cidade do final do século XIX e início do século XX.

FPM/PMSC. Fundação Pró-Memória/Prefeitura Municipal de São Carlos. Mapa do Município de São Carlos.

GOOGLE SATELLITE. Imagem da cidade de São Carlos, 2019.

GRUPO DE TRABALHO PARQUES URBANOS DE SÃO CARLOS (GTPU). Cartografia Quente. São Carlos, 2019.

GRUPO DE TRABALHO PARQUES URBANOS DE SÃO CARLOS (GTPU). Projeto Orla do Monjolinho. São Carlos, 2019.

MINISTÉRIO DO MEIO AMBIENTE (MMA). Conselho Nacional do Meio Ambiente (CONAMA). Resolução no 237 de 19 de dezembro de 1997. 
MINISTÉRIO DO MEIO AMBIENTE (MMA). Conselho Nacional do Meio Ambiente (CONAMA). Resolução no 001, de 23 de janeiro de 1986.

ONG Ciclismo São Carlos. Mapa das Rotas Ciclistas, 2019. Disponível em: <http://www.ciclismosaocarlos.org.br/ciclismo-urbano/rotas-para-bike>. Acesso em: 20 dez. 2019.

PREFEITURA MUNICIPAL DE SÃO CARLOS (PMSC). Mapa do Plano Geral Cicloviário - Estudo Preliminar. São Carlos, 2009. Arquivo Shapefile.

PREFEITURA MUNICIPAL DE SÃO CARLOS (PMSC). Mapa do Sistema de Recreio. São Carlos, 2016. Arquivo Shapefile.

PREFEITURA MUNICIPAL DE SÃO CARLOS (PMSC). Mapa das Áreas Institucionais. São Carlos, 2016. Arquivo Shapefile.

PREFEITURA MUNICIPAL DE SÃO CARLOS (PMSC). Mapa dos Equipamentos de Educação, Saúde, Lazer e Assistência Social. São Carlos, 2016. Arquivo Shapefile.

PREFEITURA MUNICIPAL DE SÃO CARLOS (PMSC). Mapa da Hidrografia. São Carlos, 2019. Arquivo Shapefile.

PREFEITURA MUNICIPAL DE SÃO CARLOS (PMSC). Mapa das Microbacias Hidrográficas. São Carlos, 2019. Arquivo Shapefile.

PREFEITURA MUNICIPAL DE SÃO CARLOS (PMSC). Mapa das Curvas de Nível. São Carlos, 2019. Arquivo Shapefile.

PREFEITURA MUNICIPAL DE SÃO CARLOS (PMSC). Mapa da Malha Viária. São Carlos, 2019. Arquivo Shapefile.

SÃO CARLOS. Lei n. 13.691, de 25 de novembro de 2005. Plano Diretor do Município de São Carlos. Prefeitura Municipal de São Carlos. São Carlos, 2005.

SÃO CARLOS. Lei no 13.944 de 12 de dezembro de 2006. Dispõe sobre a criação das Áreas de Proteção e Recuperação dos Mananciais do Município - APREM e dá outras providências. São Carlos, 2006.

SÃO CARLOS. Lei no 13.944 de 12 de dezembro de 2006. Dispõe sobre a criação das Áreas de Proteção e Recuperação dos Mananciais do Município - APREM e dá outras providências. São Carlos, 2006. Mapa da Subárea de Preservação 1 (SAPRE 1); Mapa da Subárea de Preservação 2 (SAPRE 2). Arquivo Shapefile.

SÃO CARLOS/SHS Ltda. Plano Diretor de Drenagem Urbana Ambientalmente Sustentável do Município de São Carlos. Contrato no 87/09 - PMSC/SHS Consultoria e Projetos de Engenharia Ltda. São Carlos, 2011, Vol. 1, 2 e 3. 
SÃO CARLOS/FUSP. Revisão do Plano Diretor do Município de São Carlos. Mapa do Município de São Carlos: APREMs e equipamentos de saneamento. São Carlos, 2011.

SÃO CARLOS/FUSP. Revisão do Plano Diretor do Município de São Carlos. Contrato no 40/11 - PMSC/FUSP. Produto I - Atualização da Leitura Técnica do Município de São Carlos. São Carlos, 2011.

SÃO CARLOS/FUSP. Revisão do Plano Diretor do Município de São Carlos. Contrato no 40/11 - PMSC/FUSP. Etapa 2 - Análise crítica dos instrumentos urbanísticos e da capacidade institucional da SMHDU/PMSC. São Carlos, 2012a.

SÃO CARLOS/FUSP. Revisão do Plano Diretor do Município de São Carlos. Contrato no 40/11 - PMSC/FUSP. Etapa 4 - Propostas para revisão do Plano Diretor do Município de São Carlos. São Carlos, 2012b.

SÃO CARLOS. Plano Municipal de Saneamento de São Carlos (PMSSanCa). Relatório Final. PMSC. São Carlos, 2012.

SÃO CARLOS. Lei n. 18.053, de 19 de dezembro de 2016. Plano Diretor do Município de São Carlos. São Carlos, 2016.

SÃO CARLOS. Lei n. 18.053, de 19 de dezembro de 2016. Plano Diretor do Município de São Carlos. São Carlos, 2016. Mapa das Áreas de Especial Interesse Ambiental (anexo 6). Arquivo Shapefile.

SÃO CARLOS. Decreto no 170 de 17 de julho de 2017. Cria os parques urbanos de proteção, lazer, e educação ambiental no município de São Carlos, e dá outras providências. 2017.

SÃO CARLOS. Decreto no 170 de 17 de julho de 2017. Cria os parques urbanos de proteção, lazer, e educação ambiental no município de São Carlos, e dá outras providências. Mapa dos Sete Parques, 2017. Arquivo Shapefile.

SÃO CARLOS. Decreto no 6 de 11 de janeiro de 2019. Cria os parques urbanos de proteção, lazer, e educação ambiental no Jardim Embaré, no município de São Carlos, e dá outras providências. 2019. Arquivo Shapefile.

SÃO PAULO. Lei no 16.050, de 31 de julho de 2014. Plano Diretor Estratégico do Município de São Paulo. Diário Oficial da Cidade de São Paulo. Prefeitura Municipal de São Paulo. São Paulo, 2014.

SUZANTUR São Carlos. Mapa das Linhas de ônibus, 2019. Arquivo Shapefile. 